Universidade de São Paulo

Escola Politécnica

Departamento de Engenharia de Construção Civil

\title{
INFLUÊNCIA DA FORMULAÇÃO DAS TINTAS DE BASE ACRÍLICA COMO BARREIRA CONTRA A PENETRAÇÃO DE AGENTES AGRESSIVOS NOS CONCRETOS
}

Tese apresentada à Escola Politécnica da Universidade de São Paulo para obtenção do título de Doutor em Engenharia

Sub-área: Engenharia de Construção Civil e Urbana

\section{KAI LOH UEMOTO}

Orientador: Prof. Dr. Vahan Agopyan 
Catalogação-na-publicação

Uemoto, Kai Loh

Influência da formulação das tintas de base acrílica como barreira contra a penetração de agentes agressivos nos concretos / K. L. Uemoto -- São Paulo, 2010.

$176 \mathrm{p}$.

Tese (Doutorado) - Escola Politécnica da Universidade de São Paulo. Departamento de Engenharia de Construção Civil.

1.Proteção (Concreto) 2.Pintura acrílica 3.Formulação de tinta 4.Durabilidade do concreto I.Universidade de São Paulo. Escola Politécnica. Departamento de Engenharia de Construção Civil II.t. 
"Nunca ande por caminhos já traçados, eles só conduzem até onde outros já foram".

Alexander Graham Bell 
Aos meus pais, in memorian, minha gratidão e minha saudade. 


\section{AGRADECIMENTOS}

A realização deste trabalho só foi possível graças ao incentivo e caráter multidisciplinar do Instituto de Pesquisas Tecnológicas do Estado de São Paulo e ao acolhimento acadêmico e apoio institucional da Escola Politécnica da Universidade de São Paulo.

A realização de uma pesquisa para a obtenção do doutorado é praticamente impossível sem a colaboração e apoio de colegas e amigos, principalmente na sua finalização.

Agradeço em especial, ao meu orientador e amigo, Prof. Vahan Agopyan, que me propiciou esta pesquisa com sua visão avançada, profundo conhecimento científico e opiniões esclarecedoras.

A execução desta pesquisa teria sido impossível sem o suporte financeiro da FAPESP Fundação de Amparo à Pesquisa do Estado de São Paulo.

Agradeço à Prof. Maria Alba que, além da revisão da tese, introduziu-me no campo da pesquisa, incentivou, animou e apoiou em muitos momentos.

Agradeço em especial à colega Neide Sato pelo apoio, amizade do dia a dia e valiosas contribuições ao trabalho.

Também devo agradecer à equipe do Laboratório de Concreto do Instituto de Pesquisas Tecnológicas do Estado de São Paulo pelo apoio recebido na preparação dos corpos-deprova de concreto e principalmente ao Carlos Bilesky. Ainda, agradeço aos colegas Claudio Sbrighi, João Carlos Marques, Gilberto Cavani e Valdecir Quarcioni que me acolheram nos laboratórios deste Instituto. Agradeço ao Josias Marcelino Silva pela ajuda e observações na realização dos ensaios e ao Fabiano Ferreira Chotoli na montagem da Tese.

Agradeço aos colegas Fúlvio Vitorino e Osório Thomaz, do Instituto de Pesquisas Tecnológicas do Estado de São Paulo, que muito contribuíram nas análises e discussões dos resultados de porosidade e aos técnicos Sérgio Trindade de Avila e José Luiz Gonçalves Miguel.

Agradeço ao Antonio Joaquim pelo entusiasmo e paciência nas micrografias obtidas no Microscópio Eletrônico de Varredura (MEV), e Antonio Carlos Franco Barbosa pela preparação das amostras.

A execução desta pesquisa teria sido impossível sem o auxílio da AKZO NOBEL, da BASF S.A. e Tintas Coral Ltda, que me forneceram amostras e apoio laboratorial.

Agradeço aos colegas da Escola Politécnica, Maristela Gomes da Silva, Vanessa Gomes da Silva, Claudia Terezinha de Andrade Oliveira, Rosele Correia de Lima, Nelson Diaz, Leonel Tula, pelo companheirismo, troca de experiências e incentivo nos momentos finais da tese.

Em especial, agradeço à família, principalmente Hugo, sobrinho querido, e Emílio, companheiro e amigo, pela paciência e compreensão durante as longas horas dedicadas à realização da tese. 


\section{SUMÁRIO}

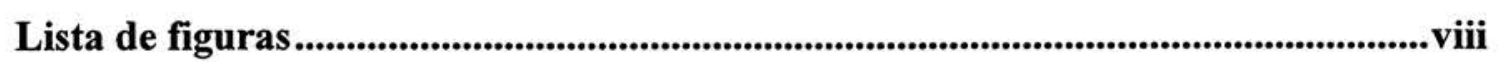

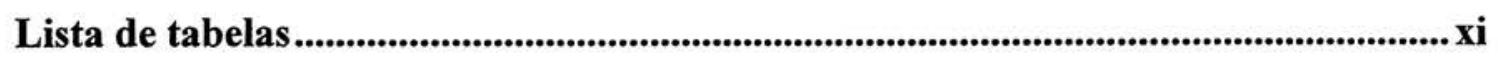

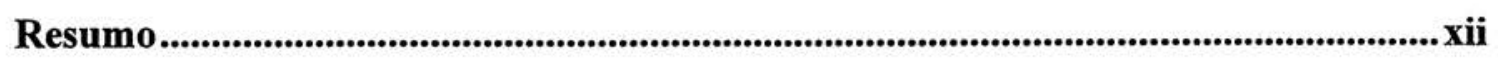

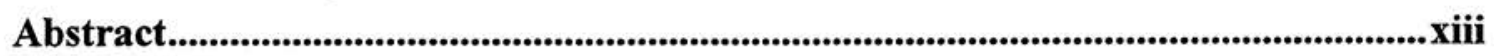

1 INTRODUÇÃO

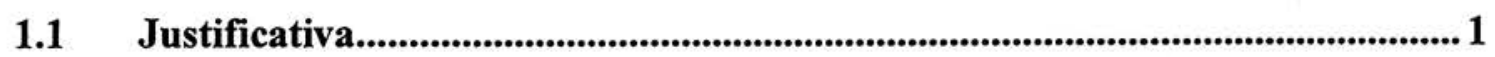

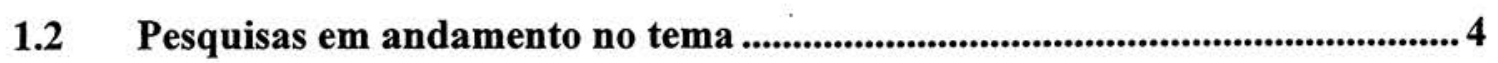

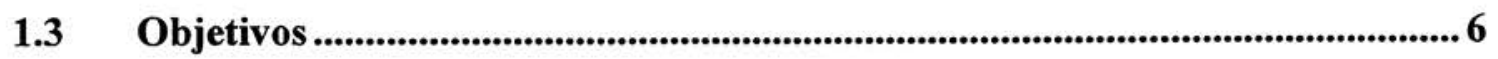

1.4 Apresentação do trabalho ..................................................................................... 7

2 PROTEÇÃO DO CONCRETO COM SISTEMAS DE PINTURA ....................

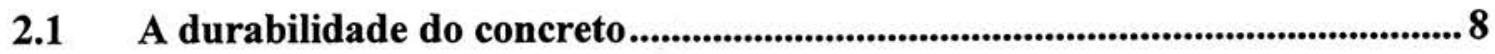

2.2 Agentes agressivos e intervenientes................................................................. 9

2.3 Sistemas de pintura de proteção

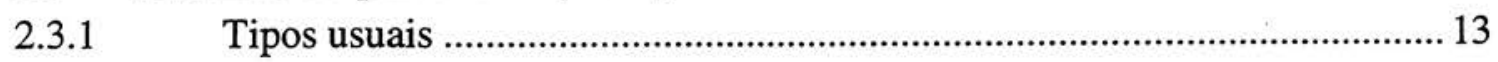

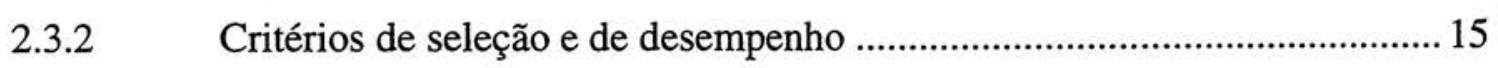

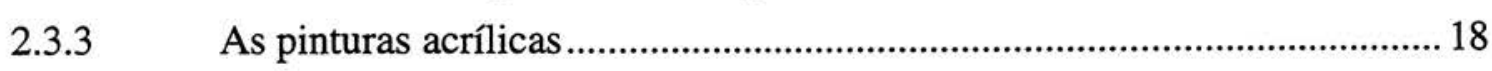

3 PARÂMETROS QUE INFLUEM NO DESEMPENHO DAS TINTAS ..........22

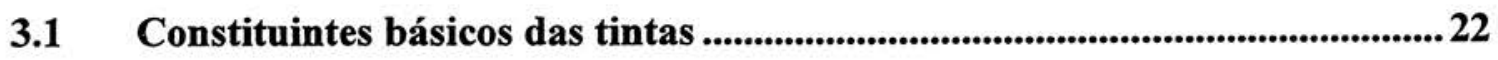

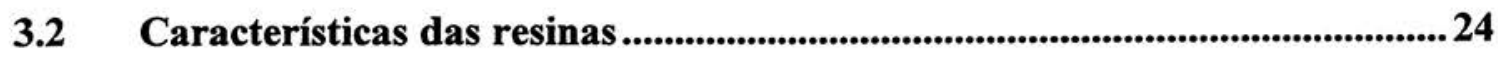

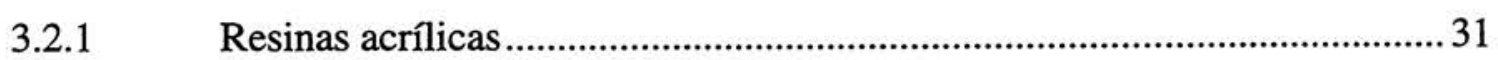

3.2.2 Mecanismos de formação de filme acrílico ................................................ 33

3.3 Agentes coalescentes e seu efeito na temperatura mínima de formação de

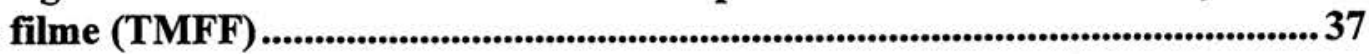

3.4 Permeabilidade das películas ao vapor e a gases ............................................ 38

3.5 Influência da concentração volumétrica de pigmentos ....................................38

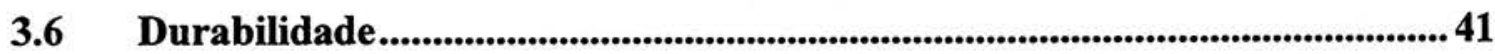


3.6.1 Metodologia de avaliação da durabilidade .................................................. 46

3.7 Influência da porosidade nas propriedades de transporte..............................51

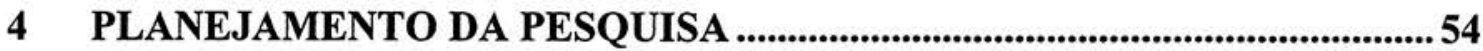

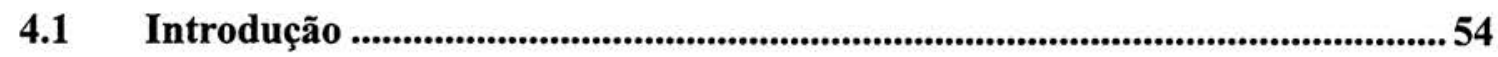

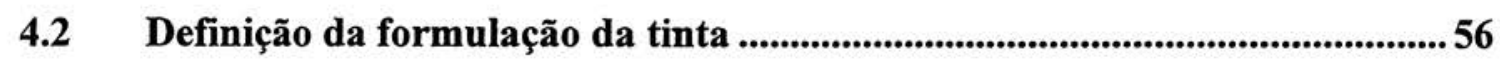

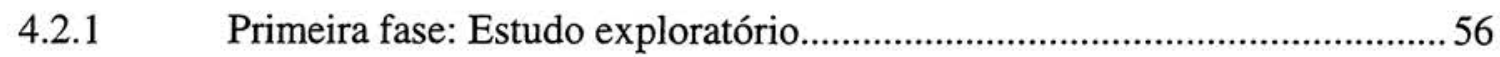

4.2.2 Segunda fase: Formulação estudada ............................................................ 58

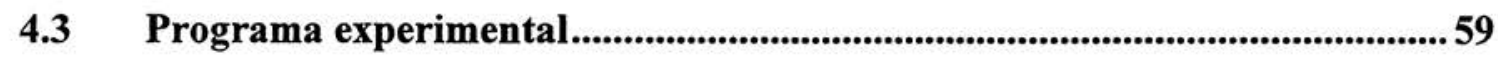

4.3.1 Preparação dos substratos de concreto..............................................................59

4.4 Caracterização dos polímeros ........................................................................59

4.4.1 Caracterização e avaliação preliminar do desempenho das tintas ............... 61

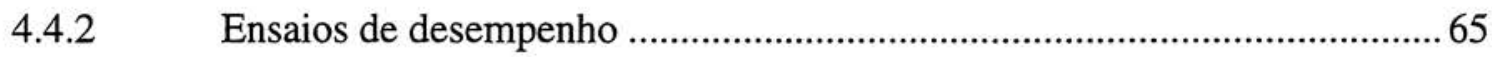

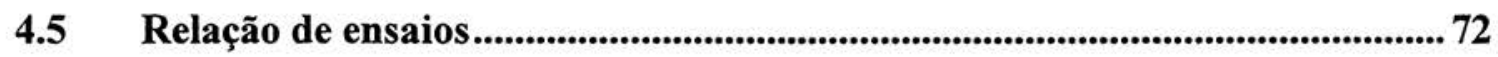

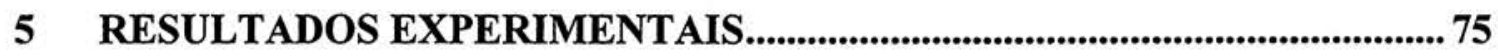

5.1 Preparação dos substratos de concreto .........................................................75

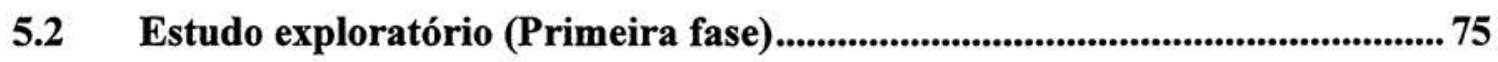

5.2.1 Caracterização das resinas ....................................................................... 75

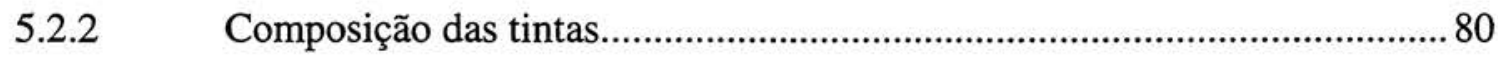

5.2.3 Caracterização e lavabilidade das tintas ....................................................... 81

5.2.4 Temperatura mínima de formação de filme (TMFF) ................................... 81

5.2.5 Permeabilidade ao vapor de água ............................................................... 82

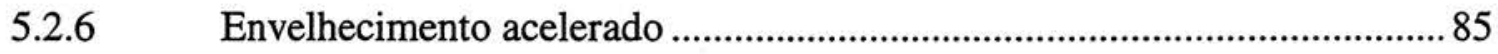

5.2.7 Comentários sobre o estudo exploratório (Primeira fase)............................ 91

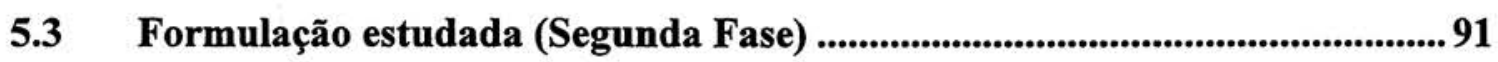

5.3.1 Caracterização das resinas ......................................................................... 92

5.3.2 Preparação de novas amostras de tintas ........................................................96

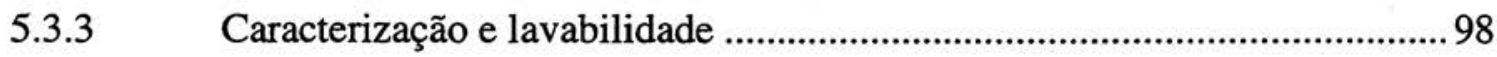

5.3.4 Temperatura mínima de formação de filme (TMFF)..................................99

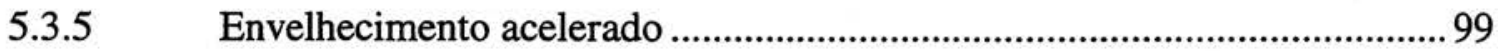

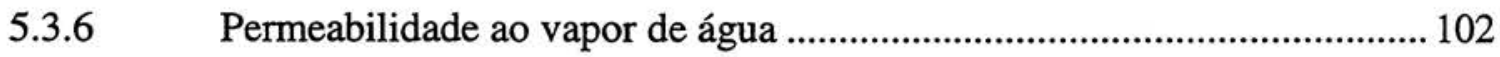




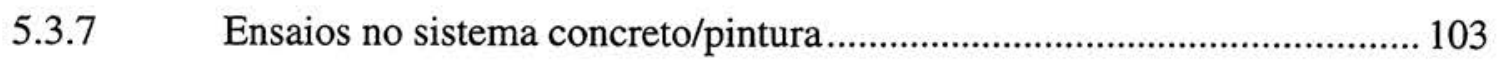

5.3.8 Porosidade e distribuição de poros ............................................................. 123

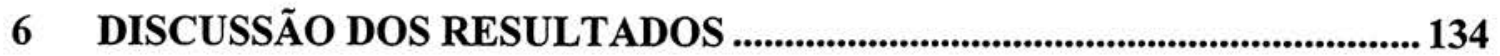

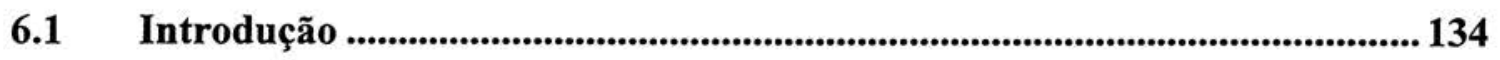

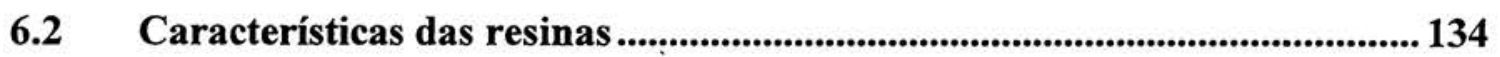

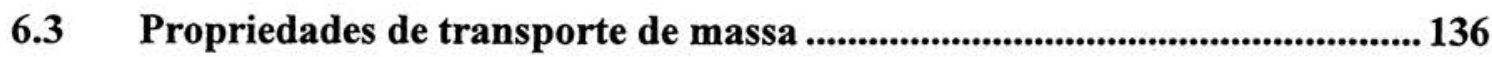

6.3.1 Discussão sobre o mecanismo de penetração de água e vapor de água.... 136

6.3.2 Discussão sobre o processo de penetração de agentes agressivos ............. 140

6.3.3 Influência do substrato .............................................................................. 141

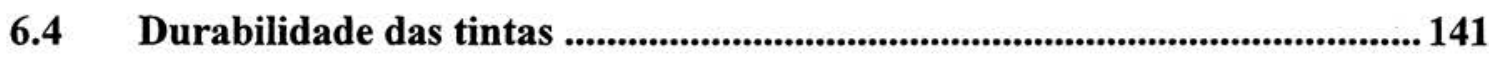

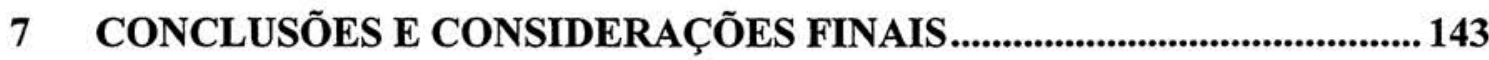

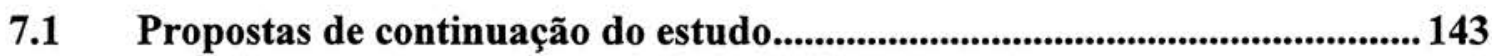

7.2 Transferência de resultados ao meio técnico.................................................... 144

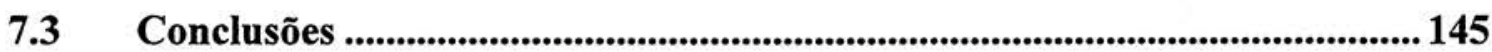

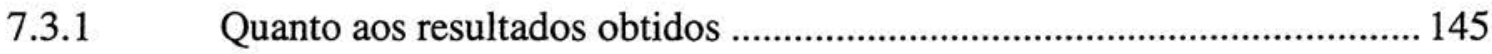

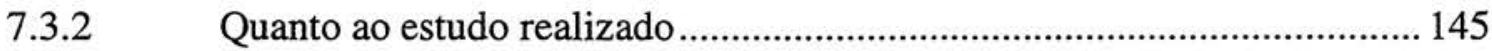

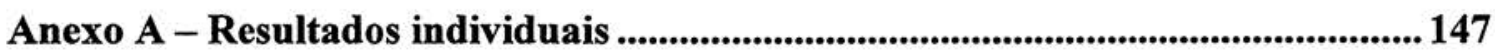

Anexo B - Preparação dos substratos de concreto ....................................................160

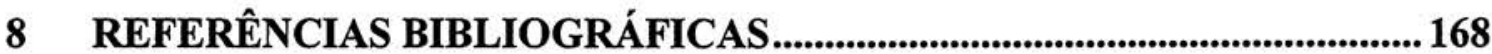




\section{LISTA DE FIGURAS}

Figura 3. 1 : Curva de distribuição diferencial (FELDMAN, 1989) ....................................30

Figura 3. 2 : Estrutura dos polímeros acrílicos (FRIEL, 1995) ..........................................32

Figura 3. 3 : Estágios da formação de ưm filme à base de dispersão aquosa (látex)

(WINNICK et al., 1992)

Figura 3. 4 : Influência da concentração volumétrica de pigmentos $(P V C)$ nas

propriedades da película de tinta (DINIZ; GNECCO, 1993)..

Figura 3. 5 : Efeito do CPVC nas características da tinta (ASBECK, 1992).

Figura 3. 6 : Os componentes dos polímeros e os fatores de intemperismo (KOCKOTT, 1989)

Figura 3. 7 : Falhas comuns (raiz e básicas) associadas a sistemas de pintura de edifícios

(MARTIN et al.; 1996)

Figura 3. 8 : Influência da faixa de dimensão dos raios dos poros nos fenômenos de transporte (MENG, 1994).

Figura 3. 9 : Classificação dos tipos de poros (BS 7591: Part4: 1993).

Figura 4. 1: Câmara climática usada na determinação da permeabilidade ao vapor de água.

Figura 4. 2 : Corpos-de-prova usados na determinação da permeabilidade ao vapor de água.

Figura 5. 1 : Espectro de infravermelho do polímero estireno-acrílico da fase exploratória.

Figura 5. 2 : Espectro de infravermelho do polímero "acrílico puro" da fase exploratória.

Figura 5. 3 : Curva de distribuição da massa molecular do polímero estireno-acrílico da fase exploratória.

Figura 5. 4 : Curva de distribuição da massa molecular do polímero "acrílico puro" da fase exploratória.

Figura 5. 5 : Curva de temperatura de transição vítrea do polímero estireno-acrílico da fase exploratória.

Figura 5. 6 : Curva de temperatura de transição vítrea do polímero "acrílico puro" da fase exploratória.

Figura 5. 7 : Aspecto das películas, obtidas com resina "acrílica pura" e com estirenoacrílico, após $300 \mathrm{~h}$ de envelhecimento acelerado.

Figura 5. 8 : Aspecto das películas obtidas com resina estireno-acrílico, após $600 \mathrm{~h}$ de envelhecimento acelerado.

Figura 5. 9 : Influência do $\mathrm{TiO}_{2}$ na exposição ao envelhecimento acelerado (300 h) 
Figura 5. 10 : Influência do $\mathrm{TiO}_{2}$ na exposição ao envelhecimento acelerado $(600 \mathrm{~h}) \ldots . . . . .90$

Figura 5. 11 : Espectro de infravermelho do polímero estireno-acrílico da segunda fase....92

Figura 5. 12 : Espectro de infravermelho do polímero acrílico puro da segunda fase.

Figura 5. 13 : Curva de distribuição da massa molecular do polímero estireno-acrílico da segunda fase.

Figura 5. 14 : Curva de distribuição da massa molecular do polímero acrílico puro da segunda fase.

Figura 5. 15 : Curva de temperatura de transição vítrea do polímero estireno-acrílico da segunda fase.

Figura 5. 16: Curva de temperatura de transição vítrea do polímero acrílico puro da segunda fase.

Figura 5. 17 : Absorção de água por capilaridade de concretos (fck $=20 \mathrm{MPa})$, com e sem pintura.

Figura 5. 18 : Absorção de água por capilaridade de concretos (fck = 40 MPa), com e sem pintura.

Figura 5. 19: Evaporação de água de concretos de fck=20 MPa, de referência e com pintura

Figura 5. 20 : Evaporação de água de concretos de fck=40 MPa, de referência e com pintura

Figura 5. 21 : Variação do teor de água ao longo do tempo, de concretos pintados (fck=20 MPa)

Figura 5. 22 : Variação do teor de água ao longo do tempo, de concretos pintados ( $\mathrm{fck}=40 \mathrm{MPa}$ )

Figura 5. 23 : Penetrabilidade do íon cloreto em concreto de $20 \mathrm{MPa}$, pintado e sem pintura.

Figura 5. 24 : Penetrabilidade do íon cloreto em concreto de $40 \mathrm{MPa}$, pintado e sem pintura.

Figura 5. 25 : Correlação entre a medida da corrente e teor de cloretos remanescentes ....120

Figura 5. 26 : Profundidade de penetração de $\mathrm{CO}_{2}$ em concreto de $20 \mathrm{MPa}$, após 28 dias de exposição e câmara..

Figura 5. 27 : Profundidade de penetração de $\mathrm{CO}_{2}$ em concreto de $40 \mathrm{MPa}$, após 28 dias de exposição e câmara.

Figura 5.28 : Micrografia da tinta de PVC $25 \%$, foto obtida com aumento de 10000 vezes.

Figura 5.29 : Micrografia da tinta de PVC $75 \%$, foto obtida com aumento de 10000 vezes.

Figura 5.30 : Micrografia da tinta de PVC 0\%, foto obtida com aumento de 500 vezes.

Figura 5.31 : Micrografia da tinta de PVC 0\%, foto obtida com aumento de 500 vezes. 
Figura 5.32 : Micrografia da tinta de PVC 0\%, foto obtida com aumento de 1500 vezes.

Detalhe da Figura 5.31.

Figura 5.33 : Micrografia da tinta de PVC 0\%, foto obtida com aumento de 250 vezes.

Figura 5.34 : Micrografia da tinta de PVC 40\%, foto obtida com aumento de 500 vezes

Figura 5.35 : Micrografia da tinta de PVC 40\%, foto obtida com aumento de 500 vezes.

Figura 5.36 : Micrografia da tinta de PVC 40\% analisada com o detector SE-1, com aumento de 1000 vezes.

Figura 5.37 : Micrografia da tinta de PVC $60 \%$ analisada com o detector SE-1, com

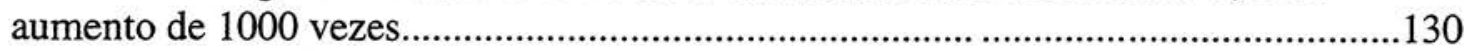

Figura 5.38 :Curvas de distribuição de volume de poros em películas de tinta...................133

Figura 6.1 :Influência do PVC das tintas na permeabilidade ao vapor de água..................140 


\section{LISTA DE TABELAS}

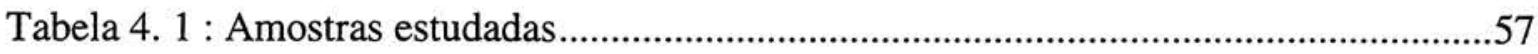

Tabela 4. 2 : Ensaios da primeira fase: Exploratória .............................................................73

Tabela 4. 3 : Ensaios da segunda fase: Formulaçoes estudadas ..........................................74

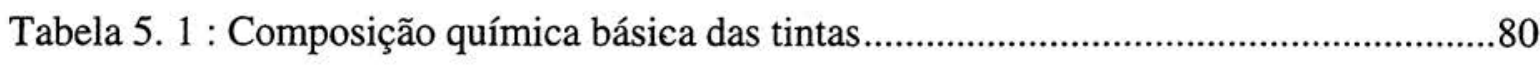

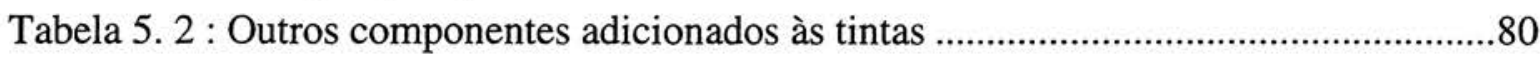

Tabela 5. 3 : Resultados de ensaios de caraterização e de desempenho ................................81

Tabela 5. 4 : Resultados de temperatura mínima de formação de filme (TMFF).................82

Tabela 5. 5 : Resultados de permeabilidade ao vapor de água..............................................83

Tabela 5. 6 : Determinaçao do brilho, sem e após envelhecimento acelerado......................87

Tabela 5. 7 : Avaliação visual após envelhecimento acelerado.............................................8

Tabela 5. 8 : Avaliação colorimétrica instrumental computadorizada .................................89

Tabela 5. 9 : Materiais usados no preparo das formulações de tintas...................................97

Tabela 5. 10 : Resultados de ensaios de caraterização e desempenho...................................98

Tabela 5. 11 : Determinação do brilho, sem e após envelhecimento acelerado ..................100

Tabela 5. 12 : Avaliação visual após envelhecimento acelerado........................................101

Tabela 5. 13 : Resultados de permeabilidade ao vapor de água .........................................102

Tabela 5. 14 : Absorção de água por capilaridade concreto / pintura

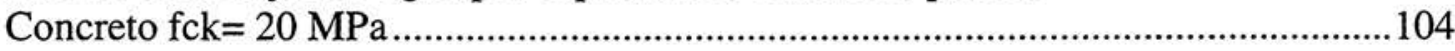

Tabela 5. 15 : Absorção de água por capilaridade concreto / pintura

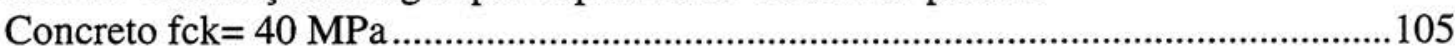

Tabela 5. 16 : Evaporação de água concreto / pintura - Concreto fck=20 MPa .................107

Tabela 5. 17 : Evaporação de água concreto / pintura -Concreto fck=40 MPa ..................107

Tabela 5. 18 : Penetrabilidade do íon cloreto em concreto com base na carga passante....113

Tabela 5. 19 : Resultados de resistência à penetração de íons cloreto

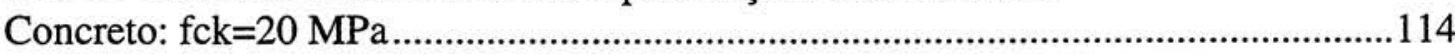

Tabela 5. 20 : Resultados de resistência à penetração de íons cloreto

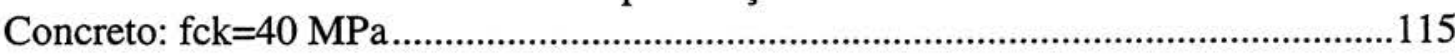

Tabela 5. 21 : Profundidade de carbonatação .....................................................................121

Tabela 5. 22 : Volume total de mercúrio penetrado.............................................................131

Tabela 6. 1 : Características das resinas.............................................................................134

Tabela 6. 2 : Dados usados na análise das propriedades de transporte de massa ...............136 


\section{RESUMO}

Uma forma de reduzir a difusão de agentes agressivos para o interior do concreto é através da aplicação de sistemas de pintura, que funcionam como uma barreira ao ingresso destes agentes. A difusão dos agentes através de películas de pintura está relacionada com a sua porosidade, que, por sua vez, depende principalmente do teor e estrutura química da resina e do teor e morfologia dos pigmentos. Esta tese teve por objetivo principal demonstrar que, com uma formulação adequada, as tintas à base de resina acrílica podem ser utilizadas como barreira de proteção eficiente contra a penetração de água e vapor de água, anidrido carbônico (C'O IND.2') e íons cloreto, em estruturas de concreto ou em outros tipos de substratos. As formulações das tintas foram definidas em função do tipo de acabamento final e obtidas pela variação da relação pigmento/resina. Foram realizados ensaios de caracterização nas tintas líquidas e nas resinas utilizadas na preparação das tintas estudadas, bem como ensaios de desempenho nas películas livres e em concretos pintados, que apresentavam resistência à compressão de 20 e 40 Mpa. Para a medida da resistência à penetração dos agentes agressivos no concreto, foram desenvolvidos ensaios acelerados, com base em metodologias de avaliação de argamassas e concretos, adaptados a substratos pintados. A microestrutura das películas de tinta foi correlacionada com as propriedades físicas das películas e dos concretos pintados. Os resultados obtidos mostram a importância da formulação das tintas nos fenômenos de transporte e, além disso, mostram que tintas acrílicas e as estirenoacrílicas com diferentes temperaturas vítreas (Tg) apresentam comportamento físico distinto. Tintas de acabamento semi-brilho conferem boa proteção contra a penetração de agentes agressivos no concreto, enquanto que as de acabamento fosco apresentam função mais decorativa do que de proteção.

Palavras chave: Proteção (concreto). Pintura acrílica. Formulação de tinta.

Durabilidade do concreto. 


\begin{abstract}
The diffusion of aggressive agents into concrete can be reduced by the application of painting systems which work as barriers to these agents. The capacity of these agents to pass through the paint is related to its porosity, which in turn is mainly dependent on the structure and content of the resin and on the morphology and content of the pigments. The main objective of this thesis is to demonstrate that with adequate formulation, paints based on acrylic resin polymers can be used as efficient barriers against the penetration of water and water vapour, carbon dioxide and chloride in concrete structures or any other porous substrate. Paint formulations were defined based on the final appearance (gloss) and obtained by varying the pigmentbinder ratio. Characterization tests on the liquid paints and polymers prepared for this study were done, as were performance tests on free dry films and painted concrete substrates, with compressive strength of $20 \mathrm{MPa}$ and $40 \mathrm{MPa}$. In order to determine the effectiveness of paint in inhibiting the diffusion of aggressive agents into concrete, accelerated tests based on methodologies for the evaluation of mortars and concrete were developed. The film's microstructures were correlated with their physical properties and with painted concrete. The results showed that the formulation of the paints has a important effect on the transport mechanism and also that acrylic and styrene-acrylic paints with different transition temperatures (Tg) do not present the same physical behavior. Glossy paints presented a high level of protection against the penetration of aggressive agents whereas matte finishes offered a more aesthetic function rather than protection.
\end{abstract}

Keywords: Protection of concrete. Acrylic paint. Paint formulation. 


\section{INTRODUÇÃO}

\subsection{Justificativa}

Por muitos séculos as tintas foram empregadas por razões estéticas mas quando foram introduzidas em países onde predominam condições climáticas muito mais severas, como a América do Norte e a Europa, foi iniciado o seu uso com fins de proteção de superfícies (FAZENDA; DINIZ, 1993). Na área da construção civil o seu emprego tem sido cada vez mais freqüente como barreira de proteção de superfícies externas de edificações como, por exemplo, o uso de pinturas na proteção de estruturas de concreto armado (HEWLETT, 1990), (LEEMING, 1990), (SWAMY; TANIKAWA, 1990).

Existem várias estratégias para o aumento da durabilidade do concreto e uma delas é evitar o contato com o meio ambiente através da aplicação de membranas e revestimentos. A penetração de agentes agressivos para o interior do concreto pode ser evitada através da aplicação de sistemas de proteção que funcionam como uma camada de separação entre o concreto e o meio agressivo, como o uso de sistemas de tratamento para evitar a difusão do cloreto (JONES et al., 1995) e do $\mathrm{CO}_{2}$ (DAVIES, 1993). Nos grandes centros urbanos, com o aumento da industrialização foi crescendo o nível de agressividade do ar atmosférico levando a uma redução na vida útil do concreto aparente. Este fenômeno levou a um uso crescente de revestimentos de proteção nas fachadas de edifícios em concreto aparente.

Estes sistemas de proteção por barreira têm grande importância no aumento da durabilidade do concreto devido à vantagem de poderem ser aplicados em estruturas recém-construídas, em superfícies de concreto de qualidade inferior ao previsto em projeto e também naquelas já existentes, como parte de um programa de manutenção e reparo de obras deterioradas (SWAMY; TANIKAWA, 1990). A vida útil desses 
materiais é geralmente menor do que aquela prevista para o concreto armado, devendo ser portanto periodicamente renovados.

A existência de uma grande variedade de produtos no mercado torna a seleção de sistemas de proteção por barreira uma tarefa difícil pois, produtos de mesma composição básica, dependendo da formulação, apresentam comportamentos distintos. O seu desempenho, relacionado às características de permeabilidade, e durabilidade são de grande importância na proteção do concreto e da sua armadura; portanto, eles devem ser selecionados com base nessas propriedades, quanto às características do concreto, das condições do meio ambiente, do projeto do edifício, como também na expectativa de manutenção do edifício.

Atualmente os produtos mais comuns para a proteção de superfícies em concreto de fachadas de edifícios residenciais e comerciais, são formulados com resinas estirenoacrílicas e poliuretânicas, em solventes orgânicos e vários tipos de silicones. No entanto, nas últimas décadas, o problema ambiental vem acarretando a necessidade de emprego de produtos à base de água em lugar de solventes orgânicos devido à emissão de menores teores de compostos orgânicos voláteis (VOC) ${ }^{1}$ (RYNDERS et al., 1995) para a atmosfera. As agências de proteção ambiental dos Estados Unidos (BREZINSKI, 1995), do Canadá e dos países Europeus (REPETTE, 1997) já impuseram restrições ao volume máximo de compostos voláteis nos revestimentos de proteção. Estas restrições levaram ao desenvolvimento de novas resinas (também chamada de veículo ${ }^{2}$ não volátil) ou resinas copolimerizadas com outras resinas as quais foram incorporadas às formulações antigas. Assim, as informações quanto ao desempenho e durabilidade dos

\footnotetext{
${ }^{1}$ Significa qualquer composto de carbono, excluindo monóxido e dióxido de carbono, ácido carbônico, carbonatos metálicos e de amônio e que participam de reações fotoquímicas na atmosfera ( BREZINSKI, 1995).
} 
produtos existentes em aplicações anteriores já não são mais aplicáveis aos produtos atuais do mercado. Além disso, as pesquisas têm sido direcionadas no sentido de produzir tintas de elevado desempenho mas de base aquosa que, além de serem menos tóxicas, não apresentam restrição quanto à aplicação sobre superfícies úmidas, como no caso de concreto recém executado, visto que a presença de umidade impede a penetração de produtos à base de solventes orgânicos.

No Brasil, as tintas acrílicas para aplicação em fachadas externas de edifícios são constituídas por resinas acrílicas de base aquosa, copolimerizadas com estireno, mas estes produtos não são muito utilizados para a proteção do concreto, prevalecendo ainda produtos à base de solvente orgânico. Hoje vêm sendo introduzidos pelas principais industrias de tinta produtos à base de acrílico puro pois, conforme resultados de uso em outros países e de estudos realizados pelos fabricantes de resina (ELFRING, 1995) e de tintas, estes resultam em películas de maior resistência ao intemperismo do que o estireno-acrílico, tradicionalmente usado no nosso país.

Os fenômenos de transporte de massa são importantes para a proteção do concreto, contra a penetração de agentes agressivos, principalmente no caso de estruturas de concreto armado. Até o momento, não existem conhecimentos suficientes quanto ao uso de tintas acrílicas puras, de base aquosa, na proteção do concreto contra a penetração de agentes agressivos, pois as informações em literatura ainda estão mais voltadas a produtos à base de solvente orgânico e a outros tipos de proteção superficial. Há necessidade de desenvolvimento de estudos com tipos de sistema de pintura, com o objetivo de estabelecer parâmetros para fornecer subsídios auxiliares na seleção e especificação de produtos para a proteção de edifícios de concreto aparente.

\footnotetext{
${ }^{2}$ Formador de filme ou a fração que aglutina as partículas de pigmento da tinta (MARTENS, 1981)
} 
Esta tese está relacionada com outra em andamento, que estuda as características dos substratos utilizados na aplicação das tintas desta tese, a ser defendida pela Física Neide Matiko Nakata Sato.

\subsection{Pesquisas em andamento no tema}

As pesquisas sobre revestimentos de proteção em concreto são relativamente recentes mesmo a nível internacional. Em 1985, HEWLETT; HURLEY (1985) apud REPETTE (1997) publicaram um artigo salientando o fato de que o tema proteção do concreto por revestimentos poliméricos era geralmente tratado de forma não-científica, resultando em pouco conhecimento básico fundamental sobre estes materiais e sua relação com o concreto e mecanismos de degradação. Observou-se que os estudos experimentais publicados na área de Engenharia Civil, sobre revestimentos de proteção, não utilizaram os conhecimentos científicos básicos existentes na área de tintas e na de polímeros, pois as avaliações eram realizadas por meio de ensaios comparativos com produtos de desempenho tradicionalmente conhecido.

Em 1990, o Departamento de Engenharia Civil da Universidade de Dundee, na Escócia, promoveu o primeiro Simpósio Internacional Sobre a Proteção do Concreto, onde foram reunidas as maiores empresas do ramo e os principais pesquisadores desta área e cujos Anais "Protection of Concrete" foram editados por DHIR; GREEN (1990). Os trabalhos publicados nestes anais procederam da Alemanha, Japão, Espanha e, na maioria, da Inglaterra. Este mesmo grupo de pesquisa promoveu outro Simpósio Internacional sobre Concreto, em 1996, cujos Anais "Concrete in the Service of Mankind-Concrete Repair, Rehabilitation and Protection" foram editados também por DHIR; JONES os quais contêm diversos trabalhos relacionados à proteção do concreto armado por sistemas de 
pintura. O ACI- American Concrete Institute ao longo de sua existência freqüentemente tem publicado trabalhos sobre este tema.

O Institute for Research in Construction do National Research Council, do Canadá, tem outro grupo que se destaca internacionalmente em reparo e proteção do concreto, sob a coordenação de Mailvaganam. Em 1992 , este pesquisador publicou "Repair and protection of concrete structures". Além dos grupos citados, o tema proteção de concreto por barreira tem sido freqüentemente abordado em eventos sobre durabilidade e recuperação de estruturas de concreto e durabilidade de materiais e componentes.

No Brasil, pelo fato da corrosão da armadura ser a principal causa de degradação de estruturas de concreto, em 1993 o Depto de Eng. Civil da Escola Politécnica da USP iniciou um projeto temático sob a coordenação do Prof. Paulo Helene intitulado "Pesquisa para Normalização de Materiais e Sistemas de Reparo de Estruturas de Concreto com Corrosão de Armaduras" o qual possui cinco grupos de pesquisa tendo um grupo estudado "Sistemas de Reparo por Barreira sobre o Concreto". Pela importância do tema este grupo possui um grande número de pesquisas, tendo já gerado duas teses de doutorado e conta com mais uma em andamento, e que são:

- Contribuição para a análise da eficiência de películas aplicadas sobre estruturas de concreto armado com objetivo de proteção contra a carbonatação, defendida pelo Eng.0 Claudio Kazmieczak, em 1995;

- Modelo de previsão de vida útil de revestimentos de proteção da superfície do concreto em meios de elevada agressividade, defendida pelo Eng.0 Wellington Longuini Repette, em 1997; 
- Avaliação de sistemas de proteção para o concreto aparente frente à penetração de cloretos, a ser defendida pela Eng ${ }^{\mathrm{a}}$ Renata Robinson de Campos Morais Ramos, em 1998.

\subsection{Objetivos}

O trabalho tem por objetivo principal demonstrar que com uma formulação adequada as tintas à base de resina acrílica podem ser utilizadas como barreira de proteção eficiente contra a penetração de vapor de água, água, anidrido carbônico $\left(\mathrm{CO}_{2}\right)$ e cloreto em estruturas de concreto ou em outros tipos de substratos. Além disso, tem como objetivos complementares:

- Desenvolver metodologia de ensaios acelerados para avaliação da permeabilidade das películas a agentes agressivos;

- Fornecer subsídios para a formulação de tintas com permeabilidade adequada para a proteção de estruturas de concreto;

- Estudar a influência da formulação, microestrutura e durabilidade de películas de tintas nos fenômenos de transporte de massa;

- Alertar o meio técnico sobre a importância da formulação da tinta nos fenômenos de transporte de massa e orientar os projetistas para a seleção dos produtos;

Do ponto de vista da aplicação prática os resultados devem contribuir para a especificação de requisitos e critérios de qualidade de tintas de proteção e elaboração de recomendações para a seleção de sistemas de pintura em programas de manutenção onde haja necessidade de reparo e proteção de elementos de fachada e de estruturas de concreto. 


\subsection{Apresentação do trabalho}

O presente trabalho está organizado em 5 partes, sendo a primeira parte constituída pela Introdução e Capítulo 2, que se inicia com dados obtidos da revisão da literatura, abrangendo aspectos genéricos da durabilidade do concreto e dos principais agentes de corrosão da armadura até os principais sistemas de pintura usados na proteção do concreto. Em seguida, são apresentados os critérios usados na avaliação das propriedades das películas quanto aos fenômenos de transporte de massa, os critérios de seleção dos produtos e as características das tintas acrílicas usadas na proteção do concreto.

O Capítulo 3 está organizado de forma didática, abrangendo conceitos básicos sobre tintas e polímeros, parâmetros que influenciam as propriedades da película que eles formam, com ênfase naquelas que afetam os fenômenos de transporte de massa. As informações obtidas foram tiradas da literatura específica neste tema.

No Capítulo 4 é discutida a metodologia da investigação experimental e os métodos de ensaios empregados e no Capítulo 5 são descritas as características dos polímeros usados na preparação das tintas, a formulação e as características das tintas estudadas, os resultados obtidos nos estudos de envelhecimento acelerado, de transporte de massa e de porosidade das películas. No Capítulo 6 é apresentada a análise dos resultados experimentais, comentários sobre as características das resinas, as correlações existentes entre microestrutura, porosidade, resultados de ensaios físicos e fenômenos de transporte de massa, durabilidade das tintas e finalmente, nas considerações finais é apresentada as conclusões e discutida a análise crítica do trabalho, meios para a transferência de resultados ao meio técnico e propostas para a continuação da pesquisa. 


\section{PROTEÇÃO DO CONCRETO COM SISTEMAS DE PINTURA}

\subsection{A durabilidade do concreto}

Para HEWLETT (1990) o concreto é um material muito versátil, fisicamente semelhante a uma rocha, freqüentemente assumido como sendo inerte e permanente como aqueles concretos geo-poliméricos ${ }^{3}$ utilizados na construção da esfinge e das pirâmides do Egito. Desde que bem executado o concreto pode ser considerado o material de construção mais durável (SWAMY; TANIKAWA, 1990).

O concreto armado, por natureza, já protege a sua armadura contra a corrosão (HELENE, 1992); a proteção baseia-se no impedimento do progresso da corrosão através de uma proteção química e de uma barreira física. Nas reações de hidratação do cimento há liberação do $\mathrm{Ca}(\mathrm{OH})_{2}$ que se dissolve na água intersticial presente nos poros e nos capilares do concreto, resultando em pH que varia de 12 a 13 , o qual confere ao concreto um caráter alcalino e que proporciona a passivação do aço. Já o cobrimento do concreto protege a camada passivante da armadura contra danos físicos e mecânicos (HELENE, 1993). A composição e as propriedades desta camada têm sido estudadas por diversos autores mas, de modo geral, sugerem diferentes composições para este filme passivador. As teorias mais aceitas são a da formação de uma monocamada constituída de uma solução sólida de $\mathrm{Fe}_{2} \mathrm{O}_{3}$ e $\mathrm{Fe}_{3} \mathrm{O}_{4}$ (LEEK; POOLE, 1990) ou da formação de um filme transparente, fino, aderente e estável, composto de duas camadas de óxido, uma interna onde predomina o $\mathrm{Fe}_{3} \mathrm{O}_{4}$ e outra externa de $\gamma$ - $\mathrm{Fe}_{2} \mathrm{O}_{3}$ (HELENE, 1993). Enquanto a camada de óxido está presente a armadura permanece intacta.

\footnotetext{
${ }^{3}$ Concretos geo-poliméricos são os concretos mais antigos e foram utilizados na construção das pirâmides do Egito (DAVIDOVITS, 1987).
} 
Vários fatores interferem no processo de corrosão e tem origem em diferentes fontes como por exemplo os fatores intrínsecos ao próprio concreto. Portanto, suas características e propriedades as quais estão relacionadas com a especificação e a qualidade do concreto, cuidados de execução como a espessura da camada de cobrimento, lançamento e cura, ou a fatores de projeto da estrutura.

O meio ambiente no qual está localizada a estrutura é outro fator que interfere na corrosão, é ele o agente promotor da corrosão. O ar atmosférico está cada vez mais poluído como resultado da industrialização, do tráfico intenso e do desenvolvimento tecnológico, resultando em teores de agentes agressivos em níveis bastante elevados, os quais aceleram a corrosão da armadura do concreto, inclusive deteriorando a superfície do próprio concreto e modificando a durabilidade prevista em projeto.

\subsection{Agentes agressivos e intervenientes}

$\mathrm{Na}$ atmosfera existem diferentes agentes agressivos que interferem na durabilidade do concreto sendo os principais: a umidade, quase sempre proveniente de águas pluviais; os poluentes, como os materiais particulados ácidos, o gás sulfídrico $\left(\mathrm{H}_{2} \mathrm{~S}\right)$, o anidrido sulfuroso $\left(\mathrm{SO}_{2}\right)$ e o carbônico $\left(\mathrm{CO}_{2}\right)$; os agentes biológicos como as bactérias, os fungos, as algas e os liquens (DERUELLE, 1991); (PERRICHET, 1984) e, na atmosfera marinha, também, os íons cloreto, aceleram a deterioração do concreto. Conforme SWAMY; TANIKAWA (1990) o íon cloreto e o $\mathrm{CO}_{2}$ são considerados os dois agentes agressivos mais importantes na deterioração de estruturas de concreto armado. A água e o vapor de água são os agentes intervenientes e são eles que transportam os íons agressivos necessários à corrosão eletroquímica.

Os íons cloreto possuem a capacidade de destruir a camada passivadora em presença de água e oxigênio, iniciando o processo de corrosão da armadura. Desenvolve-se uma 
diferença de potencial elétrico ao longo da armadura do concreto, devido ao aparecimento de regiões catódicas e anódicas, interligadas pela água dos poros da pasta de cimento que age como um eletrólito. Desta forma, em concreto seco não há corrosão da armadura e nem no concreto totalmente imerso em água, exceto quando o ar é incorporado à água, por exemplo, quando há ação de ondas na água do mar. A umidade relativa crítica para a corrosão está entre $70-80 \%$; acima destes valores de umidade relativa, a difusão de oxigênio é reduzida de modo considerável (NEVILLE, 1995).

O fenômeno de carbonatação inicia-se pela reação do $\mathrm{Ca}(\mathrm{OH})_{2}$ com o $\mathrm{CO}_{2}$ presente no ar, resultando em uma diminuição significativa da alcalinidade, o suficiente para permitir a despassivação da armadura. A principal reação envolvida no processo está ilustrada a seguir:

$$
\mathrm{Ca}(\mathrm{OH})_{2}+\mathrm{CO}_{2} \rightarrow \mathrm{CaCO}_{3}+\mathrm{H}_{2} \mathrm{O}
$$

A velocidade de carbonatação depende da relação água/cimento do concreto, do tempo, da concentração de $\mathrm{CO}_{2}$ do meio e das condições ambientais como temperatura e umidade (UOMOTO; TAKADA, 1993). Quando a penetração de $\mathrm{CO}_{2}$ atinge a armadura inicia-se a corrosão, principalmente quando há presença de umidade e salinidade. O concreto fissura e destaca devido ao aumento de volume da armadura e as regiões mais permeáveis e com menor recobrimento são as áreas mais afetadas. O processo de carbonatação é relativamente lento, em condições muito secas ou muito úmidas, e provoca uma série de alterações na estrutura da pasta endurecida; há aumento de volume de sólidos e redução do volume de poros (BOUNY, 1994).

Os compostos de enxofre e nitrogênio presentes na atmosfera podem reduzir o $\mathrm{pH}$ da água da chuva para valores abaixo de 2,5 . Estes poluentes influem principalmente nos mecanismos de degradação da superfície dos materiais de construção e têm menor 
importância nos estudos de durabilidade do concreto envolvendo a corrosão da armadura.

O fenômeno da corrosão de armaduras no Brasil é bastante freqüente. Na orla marítima predomina a corrosão causada por cloreto; em zona urbana a principal causa é a carbonatação do concreto e na zona urbana industrial causada por chuvas ácidas.

Os fatores intervenientes e os agentes agressivos atuam de modo interdependente e sinérgico, levando à deterioração prematura do concreto, o que resulta em vida útil inferior à prevista nos projetos nos quais não foram considerados esses fatores.

\subsection{Sistemas de pintura de proteção}

Existem poucas publicações sobre a proteção do concreto por sistemas de pintura. A pesquisa bibliográfica realizada mostrou que a maioria dos trabalhos, apresentados na última década, está concentrada num único Simpósio de vulto realizado na Escócia e publicados em anais sob o título "Protection of concrete", em 1990.

Os trabalhos mais antigos foram realizados por órgãos governamentais de vários estados americanos como aqueles dos Departamentos de Transportes e de Rodovias. Os resultados das pesquisas foram reunidos pelo ACI COMMITTEE 515 do ACIAmerican Concrete Institute. Este comitê foi organizado em 1936 e somente em 1966 foi publicado um guia de proteção de concreto intitulado "Guide for the protection of concrete against chemical attack by means of coatings and other corrosion resistant materials", e baseado em resultados de estudos publicados. Este guia foi posteriormente revisto e reeditado como "A guide to the use of waterproofing, dampproofing protective and decorative barrier systems for concrete", em 1977. Posteriormente foi publicado como norma ACI 515.1R-79 (revisada em 1985) e consta no "Manual of concrete practice", publicado em 1997. Os produtos citados no guia referiam-se a quase todos os 
produtos normalmente utilizados como revestimentos de proteção, desde os óleos como os de linhaça, revestimentos inorgânicos, diferentes tipos de silicone até a produtos à base de materiais poliméricos termoplásticos como as emulsões acrílicas e as de poliacetato de vinila (PVAc), termofixos, mono e bicomponentes como os epóxies e poliuretanas.

Um estudo realizado por PFEIFER; SCALI (1981) com diferentes revestimentos poliméricos, alguns desses produtos à base de resina epóxi, com diferentes teores de sólidos ${ }^{4}$, mostrou, com todos os produtos, diferentes resultados de absorção de água após 21 dias de imersão. O estudo mostrou que tintas de diferentes veículos não apresentam mesmo nível de absorção de água e que produtos do mercado constituídos por um mesmo tipo de resina, como as tintas à base de resina epóxi, constituídos por diferentes teores de sólidos também apresentam diferentes níveis de absorção de água. Todos os produtos estudados foram fornecidos por fabricantes de tinta e de produtos químicos.

\footnotetext{
${ }^{4}$ Todo o material não volátil, geralmente constituído por resina mais o pigmento
} 


\subsubsection{Tipos usuais}

Os tipos de pintura de proteção de concreto mais estudados são as tintas à base de monômeros acrílicos e metacrilatos, copolímeros de estireno/acrílicos dispersos na água ou dissolvidos em solvente orgânico (JONES et al. 1995), (MCGILL; HUMPAGE, 1990), (YASUI; FUKUSHIMA, 1990), (SASSE; HONSINGER, 1990), (HEWLETT, 1990), as tintas à base de resina epoxi isoladamente ou com alcatrão (JONES et al. 1995), o poliuretano, a borracha clorada, o Hypalon (polietileno clorossulfonado) e os vários tipos de silicones (HEWLETT, 1990), (BASHEER; MONTGOMERY; LONG; BATAYNEH, 1990) como os silanos e siloxanos.

As pinturas são classificadas como revestimentos de proteção que formam barreira enquanto que os silanos não formam barreira de proteção, mas produtos de tratamento de superficies incolores que não alteram o aspecto da estrutura; são sistemas hidrófobos que repelem a água e água contendo sais de cloreto (MCGILL; HUMPAGE, 1990) e não protegem o concreto por barreira; já os siloxanos formam películas incolores. Os silanos apresentam baixa resistência à penetração ao $\mathrm{CO}_{2}$, no entanto possuem boa resistência à absorção de água e à penetração de íons cloreto (SWAMY; TANIKAWA, 1990). A literatura mostra também o seu uso de modo combinado silano- $\beta$ siloxano e como sistema duplo combinado com resinas acrílicas (BASHEER; MONTGOMERY; LONG; BATAYNEH, 1990).

A formulação dos revestimentos de proteção afeta de modo acentuado o desempenho destes produtos quando aplicados em concreto. No entanto, na revisão da literatura realizada até o momento, só em um trabalho foram observados detalhes sobre a composição básica (SWAMY; TANIKAWA, 1990). Conforme ROBINSON (1986) apud LEEMING (1990) existe um grande número de formulações, não sendo possível a 
classificação destes materiais em grupos de composição básica, por exemplo, um produto à base de resina epóxi não se comporta de modo análogo a um outro produto com o mesmo veículo. O tipo de solvente utilizado, se o produto é ou não pigmentado parece ter muito maior importância no desempenho destes revestimentos do que o tipo de polímero. Os acabamentos fosco ou semi-brilho são obtidos modificando-se o teor de pigmento na tinta (TYSALL, 1964), no entanto, nas pesquisas realizadas não são discutidas estas diferenças de composição e nem a sua correlação com o desempenho e influência nos fenômenos de transporte de massa.

Ainda, os produtos de tratamento de superfície como os sistemas combinados silanossiloxanos são conhecidos como produtos que apresentam baixa resistência à penetração de $\mathrm{CO}_{2}$ (SWAMY; TANIKAWA, 1990) e (UEMOTO et al., 1995), entretanto, podem ser formulados com diferentes proporções de silanos e siloxanos e resultar em produtos com melhor proteção à ação de $\mathrm{CO}_{2}$, apesar de não ser citado em nenhuma das pesquisas efetuadas 5 .

Conforme experiência da autora, apesar de existir uma grande variedade de produtos, os sistemas mais usados para edificações não industriais são aqueles à base de resina acrílica e poliuretana. Os de base acrílica são encontrados na forma de tinta e de verniz, formulados como acabamentos foscos e semi-brilho. Formam filmes semi permeáveis ao vapor de água, com boa aderência ao substrato e, na forma de tinta apresentam também boa resistência à radiação UV e à alcalinidade. Outro grupo é constituído por tintas e vernizes poliuretânicos alifáticos e epoxídicos. Formam filmes de baixa

\footnotetext{
${ }^{5}$ No Brasil, normalmente é utilizada a proporção de $75 \%$ de silano para $25 \%$ de siloxano nos produtos vendidos como "silicone". Uma mudança para a proporção de $50 \%$ destas substâncias pode modificar o comportamento do produto combinado; os silanos são produtos com características hidrófobas, enquanto que, os siloxanos possuem capacidade de formação de filme. A mudança na formulação destes produtos pode alterar as características quanto à proteção contra a penetração de $\mathrm{CO}_{2}$, de modo que, produtos com desempenho ineficiente possam ser modificados para produtos adequados para esta finalidade.
} 
permeabilidade ao vapor de água e de elevada resistência mecânica. Pelo fato de serem bicomponentes são difíceis de serem aplicados; o mesmo não ocorre com tintas látex, tendo água como solvente. $\mathrm{O}$ fato dos produtos propiciarem um ou outro acabamento já altera a permeabilidade de suas películas resultando grandes diferenças no desempenho. Os vernizes apresentam menor resistência ao intemperismo devido à ausência de pigmentos os quais além de possuir a capacidade de esconder o substrato, protegem a tinta contra à ação da radiação solar.

\subsubsection{Critérios de seleção e de desempenho}

A seleção de cada um dos produtos é uma tarefa difícil (SWAMY; TANIKAWA, 1993) pois, além de existir os tipos genéricos de produtos que apresentam diferentes características de difusão, estes ainda são apresentados com um grande número possível de formulações (LEEMING, 1990). Isto significa que os produtos não podem ser selecionados apenas pelo tipo de resina básica e sim em função do seu desempenho, pois tintas acrílicas de um mesmo fabricante ou de fabricantes diferentes podem apresentar comportamentos muito diferentes devido a diferença na formulação, a ser discutido posteriormente.

O tipo de solvente, de dispersante, o teor de resina/pigmento e inclusive o tipo de monômero e a distribuição da massa molecular do polímero irão mudar o comportamento desses produtos. Os revestimentos de proteção contra a corrosão de armadura deveriam impedir a penetração de vapor de água, cloreto, $\mathrm{CO}_{2}$ e oxigênio, entretanto, as pinturas "anticarbonatação" não são necessariamente impermeáveis ao cloreto (ANDRADE, 1992). Cada um dos tipos de produto citados possui características que os tornam especialmente adequados para determinadas situações de uso e a seleção destes deve ser realizada levando-se em conta principalmente as características de 
permeabilidade, como a penetração dos agentes da atmosfera, principalmente a água, o oxigênio, o anidrido carbônico $\left(\mathrm{CO}_{2}\right)$ e a salinidade para o interior do concreto.

Atualmente, existem poucas normas que avaliam adequadamente os sistemas de proteção do concreto, mas os critérios adotados pelos pesquisadores para a avaliação dos produtos em geral são semelhantes (SWAMY; TANIKAWA, 1990), ( MOSS, 1988), (O'HARA, 1988), (SCHWAMBORN, 1993). Os estudos realizados por estes pesquisadores geralmente enfatizam a avaliação da pintura como barreira de proteção ao concreto e de sua armadura, sem avaliar as propriedades de proteção ao longo do tempo.

As características das pinturas consideradas relevantes quanto aos fenômenos de transporte de massa são:

- baixa permeabilidade ao $\mathrm{CO}_{2}$, tendo em vista que este agente reduz o $\mathrm{pH}$ do concreto;

- elevada permeabilidade ao vapor de água, para permitir a eliminação de água, na forma de vapor, presente no concreto fresco ou úmido;

- baixa permeabilidade à água líquida do meio ambiente, para evitar o transporte do íon cloreto e outros íons agressivos, para o interior do concreto;

Para estes pesquisadores, são também consideradas propriedades importantes para a proteção do concreto:

- elevada resistência da pintura à alcalinidade do concreto;

- durabilidade ao longo do tempo;

- baixo módulo de elasticidade para acompanhar os movimentos higrotérmicos do substrato resultantes de variações atmosféricas, e da retração do concreto; 
- facilidade de penetração no substrato para permitir boa aderência.

Além das propriedades referidas, são menos discutidas na literatura, outras características como:

- influência da temperatura de transição vítrea no módulo de elasticidade;

- comportamento quanto à curva de tensão-deformação e a capacidade da pintura acompanhar a fissuração do concreto sem romper a película;

- abrasão e compatibilidade térmica;

- facilidade de aplicação e aspecto do acabamento, tendo em vista exigências econômicas e estéticas.

Conforme discutido anteriormente, além das propriedades normalmente exigidas para as tintas tradicionais para aplicação em superfície externa de edificações, como boa penetração ao substrato, elevada aderência, resistência ao intemperismo, resistência à penetração de agentes agressivos, as tintas para a proteção do concreto ainda devem apresentar elevada resistência à alcalinidade e boa flexibilidade. 


\subsubsection{As pinturas acrilicas}

Conforme MARTORANO; WALDIE (1992) o conceito de proteção de edifícios contra a ação de água de chuva, através da aplicação de revestimentos, iniciou-se na França nos fins de 1960. Neste período, foi introduzido o concreto aparente como material para construção de edifícios, tendo como acabamento revestimentos à base de cimento ou à base de copolímeros de estireno-acrílico, com elevado teor de sólidos. Os materiais em questão não apresentavam compatibilidades entre si pelo fato do concreto ser um material rígido e apresentar elevada variação dimensional, tanto durante o endurecimento e cura quanto por exposição a intempéries e os revestimentos, por sua vez, por apresentarem elevado módulo de elasticidade (duro e quebradiço) não acompanhavam a movimentação higrotérmica dos substratos, de concreto ou de alvenarias.

A temperatura de transição vítrea $(\mathrm{Tg})$ é a temperatura na qual o polímero passa do estado rígido e vítreo para o estado viscoso e flexível. Os polímeros estireno-acrílicos, desta época, apresentavam $\mathrm{Tg}$ maior do que $10^{\circ} \mathrm{C}$ e resultavam em pinturas que não acompanhavam a movimentação destes substratos, especialmente em temperaturas próximas a $0^{\circ} \mathrm{C}$. Com o objetivo de aumentar a flexibilidade dos revestimentos foram introduzidos nas formulações plastificantes externos, como os ésteres ftálicos. O estireno, por ser uma resina dura, requer a adição de monômeros com características plastificantes como os ésteres acrílicos e os ftálicos. Estes monômeros amolecem o polímero o suficiente para aplicações em substratos que apresentam movimentos higrotérmicos. Esta adição resultou em dois problemas adicionais: a retenção de sujeira devido à migração do plastificante para a superfície do revestimento, causada pela ação 
do intemperismo e posterior redução de flexibilidade, devido à eliminação desta adição (MARTORANO; WALDIE, 1992).

Outro problema é que o estireno mesmo copolimerizado com o acrílico permanece fotoquimicamente ativo, podendo portanto amarelar e calcinar quando exposto a ambientes externos, mais do que os acrílicos puros, como os metacrilatos (SATTLER, 1988). A literatura cita que o acrílico puro após 2000 horas de exposição em WeatherO-meter (equipamento da marca Atlas) apresenta calcinação moderada enquanto que os estireno-acrílicos apresentam calcinação 2 a 3 vezes superior. Os polímeros constituídos por acetato de vinila, por outro lado, hidrolisam facilmente; assim, as formulações baseadas nestes polímeros apresentam baixo desempenho mesmo em substratos moderadamente alcalinos (ELFRING, 1995).

Em meados de 1970, iniciou-se o uso de polímeros $100 \%$ acrílicos com temperatura de transição vítrea $(\mathrm{Tg})$ ao redor de $-45^{\circ} \mathrm{C}$ e $P V C$ ( Pigment volume content) entre $25 \%$ e $40 \%$, sem plastificação externa, isto é, sem a adição de plastificantes, como os ésteres, na formulação da tinta. Estes polímeros resultaram em revestimentos com pegajosidade e baixa resistência à retenção de sujeira. Polímeros com temperatura de transição vítrea (Tg) inferior a zero são materiais macios ${ }^{6}$, com capacidade de produzir filmes de elevada elasticidade, os quais permitem acompanhar as expansões e contrações do concreto devido às variações térmicas ao longo do tempo, em uma grande faixa de temperatura (ELFRING, 1995). O decréscimo da Tg do polímero para valores muito baixos também leva à formação de películas de elevada pegajosidade, o que facilita a retenção de contaminantes do ar e baixa resistência à tração.

\footnotetext{
${ }^{6}$ Resina macia significa polímero que resulta em película de baixo módulo de elasticidade. Termo utilizado pelos fabricantes de tintas e de polímeros.
} 
No início de 1980 , foram tentados vários meios de obtenção de tintas de proteção, até chegar-se aos revestimentos elastoméricos de elevada espessura, à base de resina acrílica, para a proteção de edificações em concreto. Neste tipo de revestimento, as propriedades elastoméricas foram obtidas pelo uso de polímeros com baixa $\mathrm{Tg}$ e a pegajosidade evitada através do controle do nível de ligações cruzadas no polímero (MARTORANO; WALDIE, 1992). Este tipo de revestimento tem sido estudado por vários pesquisadores (SCHWAMBORN, 1993), (ELFRING, 1995), (SWAMY; TANIKAWA, 1990), os quais concluíram que este tipo de material atende às exigências necessárias para a aplicação em estruturas de concreto.

SWAMY; TANIKAWA (1990) estudaram um sistema de revestimento de elevada espessura (ao redor de $1000 \mu \mathrm{m}$ ), à base de borracha acrílica, com características muito elásticas. O produto tem como constituinte principal 2-etil-hexil acrilato; foi obtido pela reação do éster acrílico com outro componente formando uma emulsão de borracha acrílica onde o agente formador de ligação cruzada é adicionado posteriormente. Neste produto foi utilizado um monômero com características plastificantes, com temperatura de transição vítrea $(\mathrm{Tg})$ de $-65^{\circ} \mathrm{C}$ o que permite obter excelentes propriedades elásticas mesmo a baixas temperaturas devido ao seu baixo módulo de elasticidade. Os produtos obtidos com $54 \%$ em massa deste polímero, tendo como outros constituintes cargas inorgânicas e pigmentos, apresentaram películas de elevado desempenho quanto à ação de agentes agressivos, características adequadas de difusão, baixo módulo de elasticidade, resultando em produto que permite acomodar a presença de fissuras no substrato, sem resultar em rompimento da camada de revestimento. SWAMY e TANIKAWA continuam estudando este produto elastomérico até hoje e os resultados tem sido apresentados nos simpósios de durabilidade (SWAMY; TANIKAWA, 1991); (OSHIRO; SWAMY; TANIKAWA, 1994). 
Os revestimentos elastoméricos podem ser geralmente obtidos a partir de polímeros com $\mathrm{Tg}$ que varia de $-43^{\circ} \mathrm{C} \mathrm{a}-22^{\circ} \mathrm{C}$, constituídos por compostos de ácido acrílico ou metacrílico e seus ésteres e outros derivados (ELFRING, 1995).

Contatos no mercado mostraram que as tintas acrílicas convencionais da linha imobiliária do mercado brasileiro são os estireno-acrílicos obtidos pela copolimerização com estireno e com as características já citadas anteriormente. Hoje está sendo introduzida no Brasil tinta à base de acrílico puro, ainda não muito comercializada pelos fabricantes devido ao custo mais elevado do que a de estireno-acrílico. O acrílico puro existente não é equivalente ao citado na literatura, pois apresenta $\mathrm{Tg}$ ao redor de $20^{\circ} \mathrm{C}$ a $30^{\circ} \mathrm{C}$, indicando que possui propriedades diferentes daqueles com $\mathrm{Tg}$ inferior a $0^{\circ} \mathrm{C}$. No momento, no País, algumas companhias multinacionais pretendem aumentar a produção de tintas à base deste tipo de resina. É fundamental realizar estudos nesta área pois estes tipos chamados "puros" possuem propriedades diferentes das citadas em literatura e os dados existentes são resultados de pesquisas realizadas em outros países. Os resultados obtidos para as condições ambientais brasileiras irão auxiliar o mercado no conhecimento de suas características e orientar o seu emprego. 


\section{PARÂMETROS QUE INFLUEM NO DESEMPENHO DAS TINTAS}

Neste Capítulo são apresentados alguns conceitos básicos sobre as tintas e os polímeros. Pelo fato dos polímeros serem o constituinte principal das tintas as propriedades químicas e físicas desses materiais são extremamente significativas no desempenho destes produtos. O conhecimento destas propriedades é de fundamental importância para a previsão do comportamento dos respectivos materiais pois auxilia na seleção do sistema polimérico adequado para cada tipo de aplicação.

\subsection{Constituintes básicos das tintas}

De modo geral, as tintas são constituídas por três componentes principais: a resina ${ }^{7}$ ou polímero, também chamada de veículo não volátil, o pigmento, e o solvente, chamado veículo volátil. Nem sempre há necessidade de que a tinta seja constituída por estes três componentes; por exemplo, existem os vernizes que são películas transparentes e que geralmente não contêm pigmentos em sua composição. Além disso, existem os revestimentos que são aplicados em camadas muito espessas e que praticamente não precisam conter solvente em sua composição. Os três componentes geralmente estão presentes nas tintas, mas o que difere um tipo de tinta do outro é a formulação e o mecanismo de polimerização durante a formação de película (UEMOTO, 1992).

A resina, veículo não volátil, é o aglutinante das partículas de pigmento e é ele o agente formador de filme. A composição da resina tem elevada importância nas propriedades da película, apesar desta ser modificada pelo tipo e teor de pigmento presente.

\footnotetext{
${ }^{7}$ Os termos resina e polímero são usados indistintamente por LAMBOURNE (1987).
} 
O pigmento é o componente responsável pela cor, opacidade ou ação anticorrosiva, em caso de tintas para proteção de superfícies metálicas. O dióxido de titânio, por apresentar maior índice de refração, é o pigmento mais importante na formulação das tintas. É usado nas formulações para dar alvura, cobertura ${ }^{8}$ (opacidade) e durabilidade à tinta, através do seu poder de reflexão da luz. O uso de partículas na faixa de 0,2-0,25 $\mu \mathrm{m}$ e teor de $10 \%$ no filme seco, em volume, é a melhor condição para o espalhamento da luz. As partículas não atuam com eficiência em teores acima desse valor. Cada partícula tem uma esfera de influência e, em concentrações acima desse teor, existe sobreposição de influência observando-se menor eficiência no espalhamento da luz (BALFOUR; HUCHETTE, 1995).

O solvente é usado nas tintas com o objetivo de dissolver a resina e conferir viscosidade adequada para aplicação da tinta. Os solventes auxiliam na fabricação e na aplicação da tinta, mas não tem participação na sua vida útil (GNECCO, 1993). O seu teor geralmente é corrigido momentos antes da aplicação, conforme a necessidade, pois depende da sua velocidade de evaporação e da porosidade e capacidade de absorção do substrato. Normalmente, as tintas látex do mercado brasileiro, como as deste estudo, possuem em sua composição ao redor de $50 \%$ de água como solvente.

Além destes 3 principais componentes também entram na composição grande número de aditivos, adicionados em pequenas proporções e com funções diferenciadas. O aditivo é o ingrediente que adicionado às tintas proporciona características especiais às mesmas; por exemplo, modificam a reologia e a tensão superficial, estabilizam as emulsões, aumentam a resistência a fungos, alteram a temperatura mínima de formação de filme como a adição de agentes coalescentes.

\footnotetext{
${ }^{8}$ Propriedade da tinta de esconder o substrato no qual foi aplicado.
} 
Não só o tipo de polímero afeta as características da película de tinta mas o mecanismo de formação de filne; sendo as duas nas principais por evaporação do solvente ou por reação química com o catalisador ou endurecedor (LEEMING, 1990). A sua formulação também tem grande influência na porosidade da película de tinta e consequentemente no seu desempenho. Existe um grande número de formulações possíveis o que não permite classificar os produtos em grupos genéricos, por exemplo uma tinta á base de epóxi pode apresentar comportamento totalmente distinto de uma outra tinta conforme a sua formulação. O tipo de solvente utilizado na tinta ou se o produto é ou não pigmentado podem modificar mais o comportamento deste mater do que o tipo de polímero utilizado (LEEMING, 1990).

Os materiais utilizados na formulação devem ser bem proporcionados para a obtenção de tinta de boa qualidade. Até aditivos, como os espessantes, agentes coalescentes, agentes dispersantes e pigmentos têm papel decisivo na porosidade e no desempenho de um revestimento (VINK et al., 1995). Uma tinta é normalmente constituída por aproximadamente 15 substâncias químicas diferentes, algumas delas nem sempre possíveis de serem determinadas por análise química devido ao seu baixo teor, mas que afetam o seu desempenho.

O conhecimento da composição da tinta permite ter uma noção sobre alg u.uas propriedades da pintura, como por exemplo a porosidade do filme, estimar a durabilidade etc., mas para uma melhor previsão do comportamento destes materiais ainda há necessidade de complementar o conhecimento com a realização de ensaios de desempenho.

\subsection{Características das resinas}

As resinas são polímeros formados por moléculas gigantes, nas quais uma ou mais unidades básicas, chamadas de monômeros, repetem-se inúmeras vezes. Eles podem ser 
lineares, ramificad bidimensionalmente ou tridimensionalmente (cross-linked). Eles podem ser classif jos como termop cos quando no seu estado acabado podem ser repetidamente amolecidos e endurecidos, pelo aumento ou diminuição da temperatura, e classificados como termofixos quando em seu estado final são insolúveis e infusíveis. As características dos polímeros estão muito relacionadas à sua geometria, o que explica o seu comportamento e as suas propriedades (FELDMAN, 1989).

Um polímero linear geralmente é termoplástico e relativamente solúvel. No entanto, alguns tipos apresentam baixa solubilidade devido ao comprimento da cadeia ou à presença de grupos químicos ligados à cadeia. Num polímero ramificado, com poucas cadeias laterais, as cadeias praticamente não influem nas propriedades do material polimérico, afetando apenas em propriedades como solubilidade, ponto de amolecimento, trabalhabilidade, etc.

A estrutura bidimensional geralmente é obtida por reações químicas formando-se ligações cruzadas entre polímeros lineares. Mesmo a presença de poucas ligações cruzadas estas afetam muito as propriedades do material polimérico. Um aumento destas ligações pode elevar a resistência mecânica, o ponto de amolecimento e reduzir a solubilidade.

A estrutura tridimensional é obtida através de maior número de ligações cruzadas, formando uma rede. A insolubilidade, infusibilidade são propriedades atribuídas ao elevado grau de ligações cruzadas que é uma característica dos polímeros termofixos. Nas tintas, as ligações cruzadas são obtidas por meio de um agente de cura ou de ligação, também chamado de endurecedor, resultando em película de baixa porosidade.

As diferentes formas geométricas tem relação direta nas propriedades dos polímeros e resultam em películas de tinta de diferentes níveis de proteção ao substrato. 
As propriedades físicas do polímero endem da estrutura da cadeia polimérica, da massa molecular $\epsilon$ a natureza e mą̧ de das forças intermoleculares (forças de van der Waals) que se formam entre as cadeias (DANIELS, 1989). As propriedades químicas dependem da natureza química, da reatividade dos grupos, das energias de ligações, das ligações entre segmentos de cadeias e da reatividade dos grupos laterais e das terminações.

A temperatura de transição vitrea $(\mathrm{Tg})$ é definida como sendo a temperatura na qual o polímero passa do estado vítreo ou quebradiço para o estado viscoso ou similar ao da borracha (FAZENDA, 1993) e está associada à região amorfa dos polímeros (DANIELS, 1989). Os polímeros amorfos e a fração amorfa dos polímeros cristalinos são rígidos, duros e vítreos quando em temperaturas inferiores à $\mathrm{Tg}$, porém, tornam-se flexíveis, "macios"(dúcteis) e elásticos quando em temperaturas superiores a $\mathrm{Tg}$ (HARE, 1996 apud REPETTE, 1997).

A $\mathrm{Tg}$ representa a temperatura em que a mobilidade das cadeias moleculares devido à rotação de grupos laterais em torno de ligações primárias torna-se restrita pela coesão intermolecular. Em temperatura abaixo da $\mathrm{Tg}$ desaparece a mobilidade das cadeias macromoleculares e o material torna-se mais rígido. Todas as borrachas têm $\mathrm{Tg}$ abaixo da temperatura ambiente e nos polímeros de uso geral a $\mathrm{Tg}$ não ultrapassa $110^{\circ} \mathrm{C}$ (MANO, 1991).

As ramificações na cadeia aumentam a mobilidade do polímero e, assim, abaixam a $\mathrm{Tg}$ (MANO,1991) enquanto que os grupos $\mathrm{CH}_{2}$ extras nas substâncias como os metacrilatos dão impedimento estérico adicional elevando a $\mathrm{Tg}$. De modo geral, o aumento da massa molecular eleva a Tg do polímero (OLDRING; HAYWARD, 1987). Neste caso, moléculas de dimensões elevadas dificultam a mobilidade; 
conseqüentemente, é necessária mair temperatura para dar ao polímero energia suficiente para ser transformado a estado elástico. Um exemplo típico desta propriedade é a formação de ligações cruzadas no polímero produzindo moléculas maiores, de mesma composição química que o polímero original, mas com $\mathrm{Tg}$ mais elevada. A Tg aumenta linearmente com a formação de ligações cruzadas e a introdução de polímero de menor massa molecular reduz a $\mathrm{Tg}$, por exemplo, durante $\mathrm{o}$ processamento de um material polimérico (DANIELS, 1989).

A Tg é uma propriedade importante na caracterização de um polímero e está relacionada com a massa molecular e a sua distribuição (FELDMAN, 1989), a composição química, cristalinidade, estrutura espacial (FAZENDA, 1993). Rigidez da espinha dorsal ${ }^{9}$, presença de grupos laterais volumosos, ramificações, ligações cruzadas, simetria afetam a Tg (DANIELS, 1989).

A Tg está diretamente ligada às propriedades mecânicas e observa-se que com a redução da Tg há aumento de alongamento e diminuição da resistência mecânica, por exemplo, a resistência à tração (OLDRING; HAYWARD, 1987). A flexibilidade em escala macroscópica depende da mobilidade rotacional a nível molecular (ALLCOCK; LAMPE, 1990).

As diferenças marcantes existentes entre os polímeros podem ser explicadas através da teoria do volume livre, proposta por FOX; FLORY apud FRIEL (1995). De acordo com esta teoria, a $\mathrm{Tg}$ de dado polímero é a temperatura onde os espaços vazios existentes no seu interior atingem valor constante, abaixo desta temperatura. Quando há elevação de temperatura o volume livre aumenta, permitindo movimentação molecular e o polímero

\footnotetext{
${ }^{9}$ A série de átomos ligados linearmente e caracterizam a estrutura do polímero. A maioria dos polímeros são classificados pela composição dos átomos da espinha dorsal.
} 
torna-se viscoso.

A temperatura mínima de formação de filme (TMFF) está diretamente relacionada à temperatura de transição vítrea do polímero, da adição de plastificantes, agentes coalescentes, colóides, etc. Tanto a Tg e a TMFF estão diretamente influenciadas pela proporção de monômero no polímero (OLDRING \& HAYWARD, 1987). A TMFF de uma tinta deve ser baixa para facilitar a formação de filme em temperaturas baixas por que mesmo no Brasil é comum observar no inverno, no sul do país, pinturas que não conseguem formar filmes devido à baixa temperatura ambiente. Normalmente, a TMFF do polímero é diminuída pela adição de agentes coalescentes ${ }^{10}$ ou pela adição monômero de menor Tg. Ambas as propriedades são diretamente influenciadas pela proporção de monômero no polímero. Por exemplo se a Tg de um homopolímero estireno é de $100^{\circ} \mathrm{C}$ e a do homopolímero butilacrilato é $54^{\circ} \mathrm{C}$, o copolímero formado deverá possuir $\mathrm{Tg}$ entre estas duas temperaturas, dependendo da proporção relativa de cada um dos dois homopolímeros.

A massa molecular dos polímeros e a sua distribuição são características importantes na química dos materiais poliméricos. Nos compostos químicos convencionais cada espécie possui uma determinada massa molecular e o mesmo não ocorre com os polímeros. Eles são constituídos por uma mistura de macromoléculas de estrutura química similar mas com massas moleculares diferentes e esta característica pode alterar significativamente as propriedades do polímero. Ela normalmente é quantificada pelo número médio $\left(M_{n}\right)$ e pela massa molecular média $\left(M_{w}\right)$, calculadas pelas seguintes expressões 3.1 e 3.2 (FAZENDA, 1993).

\footnotetext{
${ }^{10}$ São solventes, de elevada temperatura de ebulição, incorporados às emulsões com o objetivo de auxiliar a formação de filme (MARTENS, 1981).
} 
$\dddot{M}_{n}=\frac{\sum N_{i} M_{i}}{\sum N_{i}}$

$M_{n}=$ média aritmética das massas moleculares das macromoléculas contidas numa determinada massa de polímero

$W=$ massa do polímero, em gramas

$\sum N_{i}=$ número total de macromoléculas existentes em W

$\dddot{M}_{w}=\frac{\sum W_{i} M_{i}}{\sum W_{i}}$

$M_{w}=$ média das massas de cada macromolécula existente em uma determinada massa do polímero

$W_{1}, W_{2}, W_{i}=$ massa das moléculas $1,2, i$, respectivamente.

O desempenho dos revestimentos acrílicos varia de modo acentuado conforme a estrutura do polímero (VINK et al., 1995). Estas diferenças de estrutura são importantes na formulação das tintas, pois influenciam fundamentalmente nas características da película como a velocidade de secagem e cura, a aplicabilidade (O'HARA, 1988), as propriedades mecânicas, a solubilidade, a reologia, a penetrabilidade no substrato, etc.

Outro conceito importante nos polímeros é o grau de polimerização que representa a distribuição dos vários comprimentos de cadeia. Este parâmetro tem grande efeito nas propriedades do material. Freqiientemente a relação $M_{w} / M_{n}$ é usada para determinar o grau de espalhamento da distribuição das massas moleculares.

O polímero é monodisperso quando $M_{w}=M_{n}$, sendo homogêneo e constituído por macromoléculas de mesma massa molecular; o polímero é polidisperso quando não é homogêneo e a relação $M_{w} / M_{n}$ é maior do que 1 . Na Figura 3. 1 a curva 1 ilustra uma 
relação $M_{w} / M_{n}$ baixa, isto é, uma polidispersidade inferior à da curva 2 que possui relação $M_{w} / M_{n}$ elevada (FELDMAN, 1989).

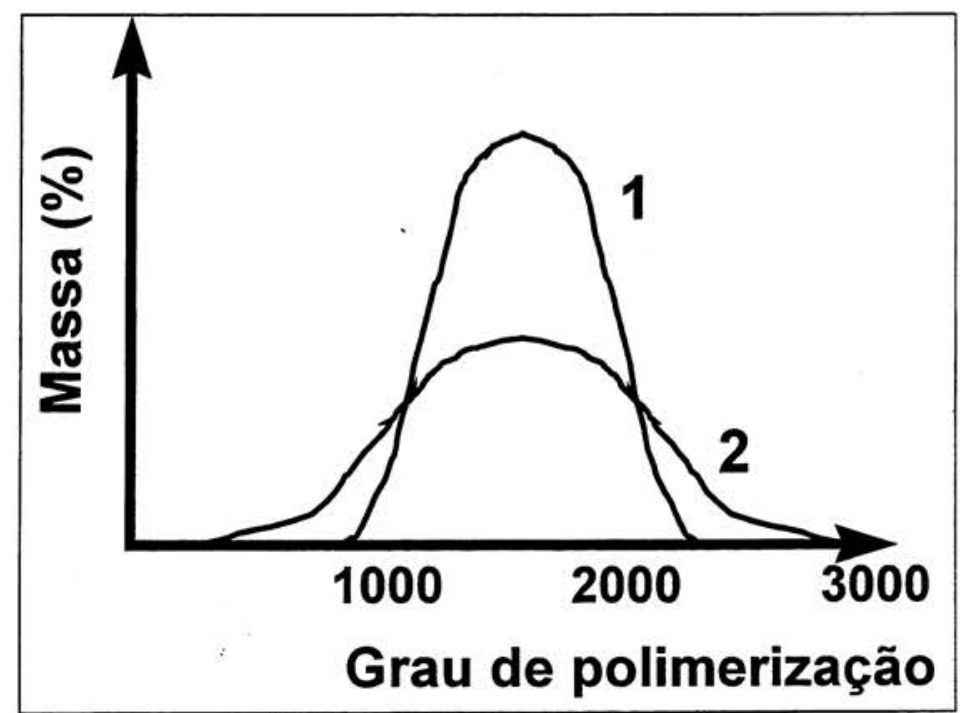

Figura 3. 1 : Curva de distribuição diferencial (FELDMAN, 1989)

A maioria das propriedades de um polímero esta relacionada principalmente ao tamanho das suas macromoléculas e depende muito mais das moléculas grandes do que das pequenas. A caracterização de um polímero é completa quando se relacionam os valores das massas moleculares médias $\left(M_{w}\right.$ e $\left.M_{n}\right)$ com a distribuição da sua massa molecular.

A polimerização pode resultar em polímeros de estrutura cristalina ou amorfa. Normalmente o grau de cristalinidade é avaliado com o objetivo de acompanhar os processos de cura e de envelhecimento dos materiais poliméricos.

Características como a geometria, massa molecular, polidispersidade refletem o tipo de agregação da cadeia polimérica. Se a macromolécula tem estrutura suficientemente regular pode haver algum grau de cristalização. Esta propriedade ocorre em polímeros lineares com poucas ramificações e com elevada regularidade na cadeia. O polietileno e poliamida são cristalinos pois suas macromoléculas têm elevada regularidade e simetria. 
Regiões cristalinas têm grande influência nas propriedades mecânicas como a resistência, massa específica, dureza, temperatura de fusão, etc. (FELDMAN, 1989). As estruturas amorfas são características dos elastômeros e da maioria dos revestimentos.

\subsubsection{Resinas acrilicas}

A sua principal característica é a resistência à radiação solar comparativamente a outros polímeros de mesmo custo. É uma das duas resinas mais utilizadas como revestimento de pintura. Ela é usada isoladamente ou combinada com outras resinas, sendo representada pela fórmula genérica $\mathrm{CH}_{2}=\mathrm{CRX}$, onde $\mathrm{R}$ geralmente é um átomo de $\mathrm{H}$ ou um grupo $\mathrm{CH}_{3}$ (OLDRING; HAYWARD, 1987). O termo acrílico é aplicado para produtos à base de monômero acrílico ou metacrílico, mas a indústria tem estendido a terminologia para os copolímeros. As duas séries de monômeros acrílicos mais usadas para a produção de tinta são derivadas do ácido acrílico e do ácido metacrílico e os derivados ésteres acrílicos, ésteres metacrílicos, butil acrilatos e metilmetacrilatos.

As resinas acrílicas possuem grande variedade de monômeros com propriedades totalmente diferentes e a seleção para a formulação dos produtos para cada aplicação é feita com base nas suas propriedades (OLDRING; HAYWARD, 1987). Poucas resinas homopoliméricas são usadas isoladamente na produção de tintas, pois geralmente são copolimerizadas com um ou mais tipos de monômero para formar um copolimero com as características desejadas. Como exemplo, o copolímero acetato de vinila-versatato, no qual o versatato que é um monômero do éster do ácido versático tem função plastificante, modificando os filmes de acetato de vinila quebradiços (frágeis) em filmes mais flexíveis. Um outro exemplo de copolimerização é o estireno acrílico utilizado no estudo; a presença de elevados níveis de estireno produz filmes duros e quebradiços, 
amarela quando exposto à radiação solar mas tem custo baixo, resultando em pintura economicamente mais acessível.

Conforme a literatura, os copolímeros acrílicos de modo geral apresentam durabilidade inferior aos acrílicos puros, mas existem trabalhos que mostram que a durabilidade de ambos é semelhante. Os acrilatos têm geralmente menor durabilidade em ambientes externos comparativamente aos metacrilatos, aos etilacrilatos e aos metacrilatos e todos eles com menor durabilidade do que os equivalentes butilmetacrilatos. Estudos realizados mostram que a resistência ao intemperismo dos polímeros acrílicos decresce na seguinte ordem: metilmetacrilato (MMA) > butilmetacrilato > MMA/butilmetacrilato> MMA/ etilacrilato (VINK et al., 1995).

O monômero que forma a espinha dorsal é o que determina a $\mathrm{Tg}$ do polímero e influencia nas propriedades como flexibilidade, dureza, durabilidade etc. Os monômeros como o etil e butilacrilato são usados para plastificar a espinha dorsal do polímero (O'HARA, 1988). Os dois monômeros principais que formam as resinas acrílicas empregadas em tintas são os acrilatos e metacrilatos; suas respectivas formas estruturais estão ilustradas na Figura 3. 2 (FRIEL, 1995).

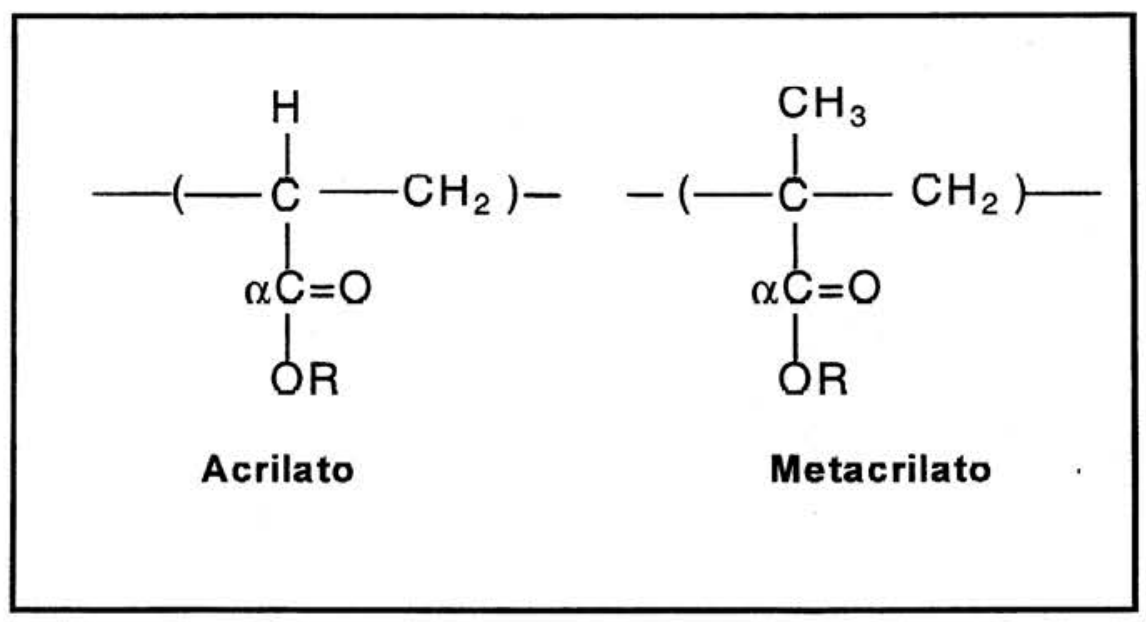

Figura 3.2 : Estrutura dos polímeros acrílicos (FRIEL, 1995) 
O polietilacrilato possui uma $\mathrm{Tg}$ de $-22^{\circ} \mathrm{C}$. Um aumento do grupo metila (-CH3) no $\mathrm{C} \alpha$ da cadeia principal aumenta a $\operatorname{Tg}$ para $8^{\circ} \mathrm{C}$ devido ao aumento da rigidez do polímero. A mobilidade é obtida pelo aumento de temperatura e consequentemente a Tg é alterada. Um polímero obtido a partir de metilacrilato apresenta alongamento de $750 \%$ enquanto que um polímero obtido com monộmero metilmetacrilato, com aproximadamente mesma massa molecular, é mais duro e rígido com alongamento de apenas $4 \%$ (FRIEL, 1995).

As propriedades gerais dos monômeros acrílicos e metacrílicos e seus copolímeros, geralmente a flexibilidade e dureza, podem ser deduzidas a partir dos dados de massa molecular e da $\mathrm{Tg}$ dos monômeros usados na preparação do polímero. De modo geral o grupo éster dos polímeros pode ser constituído por metil, etil e até butil. O grupo éster com cadeia maior do que butil forma polímeros macios, mais flexíveis mas também forma películas mais pegajosas e com $\mathrm{Tg}$ baixas. Quanto menor a $\mathrm{Tg}$ maior é a pegajosidade, resultando em polímeros adequados para a fabricação de colas e adesivos.

\subsubsection{Mecanismos de formação de filme acrílico}

Os polímeros acrílicos mais usados para produção de tintas são os ésteres acrílicos e o ácido metacrílico, e são encontrados na forma de solução e de emulsão.

Os polímeros acrílicos em solução geralmente são copolímeros de ésteres acrílicos e metacrílicos, preparados pela polimerização direta em solvente, como o tolueno, o xileno, as cetonas e os ésteres. Existem dois tipos de polímeros acrílicos, os termoplásticos, os quais curam pela evaporação do solvente, e o reagrupamento dos polímeros anteriormente dissolvidos, scm mudança da natureza química durante a secagem, e os termofixos, tambèm conhecidos por termorigidos, os quais contêm 
grupos funcionais monômeros acrílicos que reagem com grupos funcionais, como o epóxi, a melamina, o isocianato, com capacidade de formação de ligações cruzadas, para formar uma rede tridimensional (FRIEL, 1995), (OLDRING; HAYWARD, 1987). Estes últimos formam um emaranhado de macromoléculas bem interpenetrado, que após a evaporação do solvente resulta em filme de baixa permeabilidade e de elevado desempenho (WINNICK et al., 1992).

Nos polímeros acrílicos em emulsão, também conhecidos no mercado como látex, o filme forma-se através da coalescência de partículas que é um fenômeno físico e não químico. Diferente das tintas à base de solvente orgânico temos uma suspensão heterogênea, descontínua, onde as partículas poliméricas estão dispersas em um meio aquoso descontínuo. Esta dispersão é estável devido à presença de emulsionantes e colóides na superfície da partículas. Na Figura 3. 3 são ilustrados os vários estágios da formação de um filme durante a secagem de uma dispersão aquosa de um látex macio (WINNICK et al., 1992). 


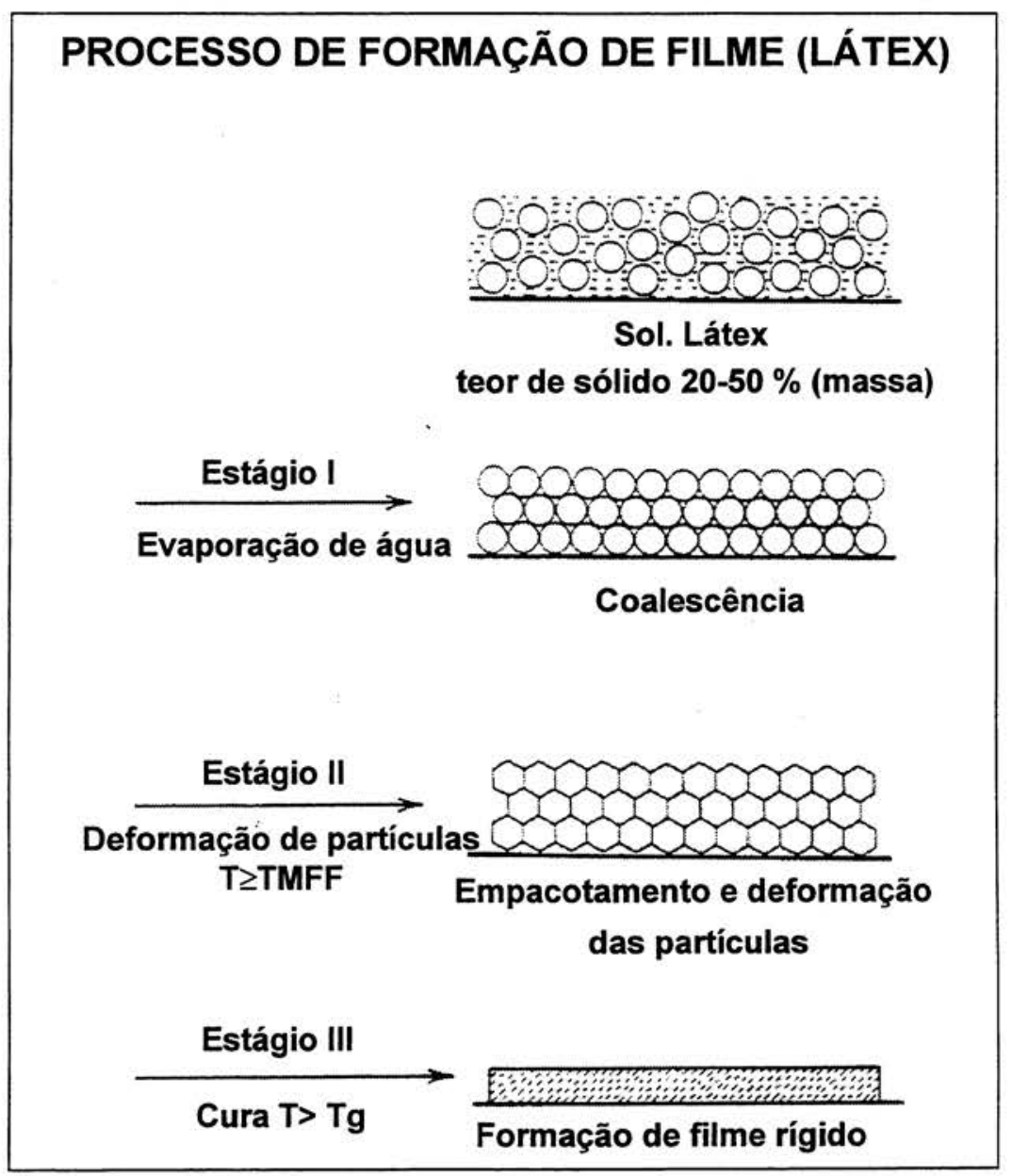

Figura 3. 3 : Estágios da formação de um filme à base de dispersão aquosa (látex) (WINNICK et al., 1992)

Há uma fase polimérica separada na forma de esferas individuais dispersas em um meio aquoso. No estágio I a água é evaporada ou absorvida pela porosidade do substrato e as partículas poliméricas esféricas tendem a se fundir entre si (coalescer). A coalescência ocorre devido à ação de forças capilares e de tensão superficial; ocorre a saída da água no interior das partículas poliméricas (FAZENDA, 1993). Conforme a literatura (WINNICK et al., 1992), (RYNDERS et al., 1995), a obtenção de filme contínuo e isento de vazios é obtida pela deformação de esferas de polímero (estágio II). Existem forças de atração e repulsão de inúmeras fontes entre as partículas, incluindo forças capilares intersticiais e resistência à deformação. A coalescência ocorre quando as 
forças de atração entre as partículas é maior do que as de repulsão (RYNDERS et al., 1995). O filme é formado em temperaturas iguais ou pouco acima da temperatura mínima de formação de filme (TMFF). O potencial de formação de filme está relacionado com a capacidade de deformação e, desta forma, as emulsões de polímeros mais duros são mais resistentes à deformação do que as emulsões de polímeros mais macios. A deformação é resultado da combinação de forças de tensão superficial das partículas de polímero, de forças de atração e repulsão provenientes de fontes variadas e do módulo de elasticidade do látex. A deformação estando dificultada não se forma filme de baixa porosidade após a evaporação da água (MARTENS, 1981). Quando a maior parte da água foi eliminada pela evaporação as partículas estão muito próximas umas das outras; neste estágio (III), a emulsão tem a forma de um gel e o filme formado já não pode ser reemulsionado com adição de mais água. É este ponto onde ocorre a coalescência propriamente dita; a velocidade de evaporação da água é bem mais lenta e o processo é irreversível.

Os polímeros acrílicos termoplásticos, em solução, são mais utilizados na produção de tintas da linha industrial e automotiva. Pelo fato destes polímeros constituírem um emaranhado bem interpenetrado, após a evaporação do solvente, formam filmes de baixa porosidade. Já os polímeros acrílicos em emulsão formam filmes bem mais porosos e de maior permeabilidade ao vapor de água do que os polímeros acrílicos em solução correspondentes, resultando em menor proteção ao substrato. Até o momento, os produtos tendo água como solvente não alcançam o desempenho obtido para os tradicionais sistemas com solvente orgânico. No entanto, devido às restrições quanto ao VOC o uso de produtos com solvente aquoso está sendo ampliado para outras áreas; os estudos de mecanismo de formação de filme por coalescência estão se tornando cada vez mais importantes por ser o estágio onde se pode influenciar a redução da porosidade 
do filme de tinta (WINNICK et al., 1992). Nem sempre há necessidade de uso de revestimentos estanques à água, mas um revestimento de proteção é considerado de elevado desempenho quando apresenta baixa permeabilidade.

\subsection{Agentes coalescentes e seu efeito na temperatura mínima de formação de filme (TMFF)}

São solventes de elevada temperatura de ebulição, incorporados às emulsões com o objetivo de auxiliar a formação de filme (WINNIK et al., 1992). Existem muitos tipos de emulsões poliméricas, alguns tipos são macios e formam filmes de baixo módulo e sem pegajosidade à temperatura ambiente, outros tipos são duros e necessitam de adição de agentes coalescentes com a finalidade de amolecer essas emulsões, baixando a sua temperatura de formação do filme. Normalmente, a resina polimérica deve ser suficientemente macia para coalescer em temperatura baixa, por exemplo, inferior a $8^{\circ} \mathrm{C}$, e suficientemente dura para formar filme sem pegajosidade após a evaporação da água (MARTENS, 1981) e garantir uma película sem problemas de retenção de sujeira, após a secagem. Os agentes coalescentes não são retidos pela película, apesar de permanecerem na mesma por longo tempo (FAZENDA, 1993); eles auxiliam a formação do filme de tinta abaixando a temperatura de formação do filme à temperaturas inferiores à temperatura de transição vítrea.

O tamanho das partículas de agente coalescente têm grande influência na porosidade da película de tinta (FAZENDA, 1993). Os desenvolvimentos nessa área estão voltados ao estudo do mecanismo de formação de filme e a influência destes agentes na porosidade das películas (WINNICK et al., 1992) devido à necessidade de obtenção de tintas à base de água, de baixa permeabilidade à difusão de agentes agressivos. Uma coalescência insatisfatória pode resultar em filmes com fissuras e trincas, elevada porosidade e inclusive com problemas de calcinação (RYNDERS et al., 1995). 


\subsection{Permeabilidade das películas ao vapor e a gases}

Pelo fato do polímero ser o constituinte principal das tintas, as suas características afetam de modo acentuado as películas resultantes; são eles que formam na pintura uma barreira contra gases e vapores. A difusão dos agentes através da película ocorre devido à passagem de moléculas pequenas, de vapor e de gases, através dos vazios e falhas entre as moléculas dos polímeros (FELDMAN, 1989).

A difusão é medida pela permeabilidade da película a estes agentes e depende principalmente da sua estrutura que, por sua vez, depende da composição química, teor de resina, teor e morfologia dos pigmentos, dos aditivos usados na sua formulação, da espessura do filme e até da forma de aplicação. O transporte ocorre intersticialmente, através de poros permanentes ou transitórios. A permeação de moléculas pequenas através da película se dá nas regiões amorfas, onde as cadeias macromoleculares estão mais afastadas. A presença de regiões cristalinas reduz a permeabilidade (MANO, 1991).

Qualquer tinta oferece proteção por barreira mas algumas são mais eficientes do que outras em função de sua porosidade. Quanto mais fina a camada de pintura e menor for a penetração dos agentes do meio maior é a eficiência da barreira. BENTZ; NGUYEN (1990) observaram que a relação entre a espessura de um meio homogêneo e a difusão em um plano deste meio é de natureza quadrática. Assim, o tempo gasto para atingir uma determinada condição é multiplicado por um fator quatro quando se dobra a espessura da película.

\subsection{Influência da concentração volumétrica de pigmentos}

Um dos parâmetros mais utilizados para descrever a composição (formulação) de uma tinta é a concentração volumétrica de pigmentos, denominado internacionalmente por 
PVC (Pigment volume content). O PVC é definido como sendo a fração volumétrica percentual do pigmento sobre o volume total de sólidos do filme seco:

$$
P V C=\frac{V p}{V p+V v} x 100
$$

onde,

$V p=$ volume de pigmento

$V v=$ volume de veículo sólido

O teor de pigmento presente na formulação da tinta é um fator que influi de modo significativo na porosidade e permeabilidade de um sistema de proteção por barreira. Um elevado teor de pigmento significa proporcionalmente um baixo teor de resina; desta forma, numa tinta de alto $P V C$ há muito pigmento para pouca resina. Como a resina é responsável pela permeabilidade da tinta, quanto maior o teor de pigmento mais porosa é a película de tinta e quanto menor o teor de pigmento mais eficiente a proteção. Na Figura 3. 4 é ilustrada a influência do $P V C$ nas características da película de tinta (DINIZ; GNECCO, 1993).

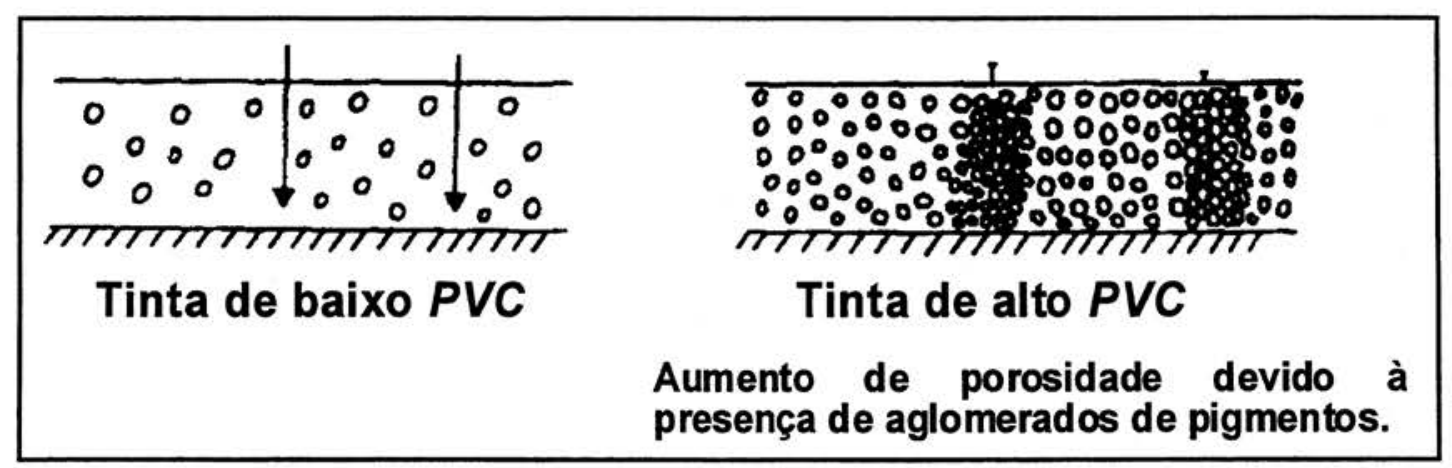

Figura 3. 4 : Influência da concentração volumétrica de pigmentos $(P V C)$ nas propriedades da película de tinta (DINIZ; GNECCO, 1993) 
Com um elevado teor de veículo não volátil (resina) e baixo teor de pigmento, todas as partículas ficam envolvidas pela resina; aumentando-se o teor de pigmento pode-se chegar a um ponto onde não existe resina suficiente para preencher todos os vazios existentes entre as partículas de pigmento. Neste ponto, no filme, os pigmentos ficam aglutinados somente em alguns pontos e a película de tinta sofre uma variação acentuada em suas propriedades (MARTENS, 1981), por exemplo, elevado aumento na permeabilidade a gases como o $\mathrm{CO}_{2}$, vapor de água e outros líquidos. Em 1949, ASBECK e VAN LOO introduziram o conceito de concentração volumétrica crítica de pigmento (CPVC) como sendo de importância fundamental na formulação das tintas. $\mathrm{O}$ PVC Crítico (CPVC) tem sido definido como o ponto onde a porcentagem em volume de pigmentos no filme tem veículo suficiente para preencher todos os vazios existentes entre as partículas de pigmento, após a evaporação do solvente (ASBECK, 1992). Um aumento adicional de pigmento leva o PVC a um ponto acima do crítico, resultando em película sem coesão, descontínua e de elevada porosidade. As tintas não são formuladas para serem comercializadas no $C P V C$. $\mathrm{O}$ valor é apenas usado como referência na avaliação do desempenho do produto e muitas vezes são formuladas com valores de CPVC pouco acima, para a melhoria da qualidade do filme, ou pouco abaixo do valor crítico, para aumentar a opacidade (NOLAN; KAVANAGH, 1995).

Em geral, quanto maior o teor de veículo na formulação, maior é a resistência aos efeitos deletérios da radiação solar por que a degradação da película ocorre superficialmente. A pintura possuindo alto teor de veículo tem menor possibilidade de calcinação e maior resistência à alteração de cor. $\mathrm{O}$ aumento da relação pigmento/resina reduz o brilho, sendo a variação nesta propriedade mais significativa na faixa entre $0,9: 1$ até 1,1:1 (TYSALL, 1964). A Figura 3. 1 mostra o efeito do CPVC nas características da tinta (ASBECK, 1992). 


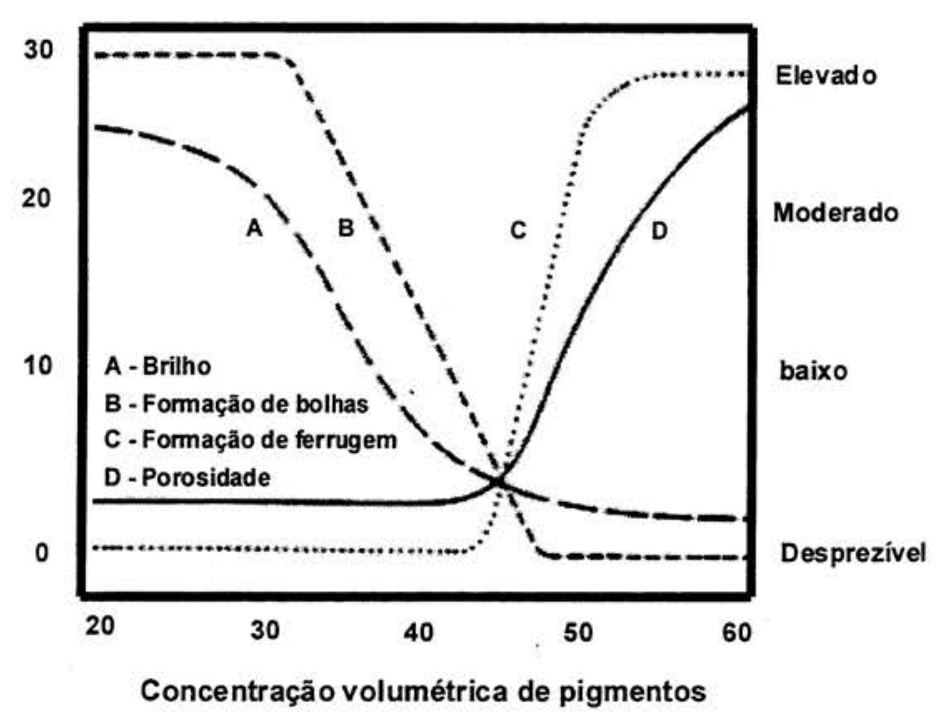

Figura 3.5 : Efeito do CPVC nas características da tinta (ASBECK, 1992).

Portanto, o $P V C$ é de grande importância na qualidade do produto além de ser o principal responsável pelo aspecto de acabamento da película. Na prática, os dados de $P V C$ dão uma noção da permeabilidade do filme de tinta além de permitir distinguir os acabamentos brilhante, semi-brilho e fosco. As tintas foscas possuem um $P V C$ elevado enquanto que uma tinta semi-brilho possui um $P V C$ baixo.

\subsection{Durabilidade}

A resistência dos materiais poliméricos ao intemperismo, como as tintas, depende basicamente do tipo, da composição básica e microestrutura dos seus polímeros, sendo os amorfos os mais sensíveis. A estrutura dos polímeros termoplásticos, que é o caso do polímero acrílico, é caracterizada pelo grau de cristalinidade, isto é, pela proporção de cadeias organizadas. Quando as cadeias são organizadas os polímeros são cristalinos e quando irregulares são amorfos, sendo os últimos os mais susceptíveis à degradação. 
O envelhecimento pode ser definido como um processo de deterioração de materiais poliméricos, resultado de efeitos combinados de radiação solar, calor, oxigênio, água, agentes biológicos e outros fatores atmosféricos como os gases e os poluentes, conforme ilustrado na Figura 3. 6 (KOCKOTT, 1989).

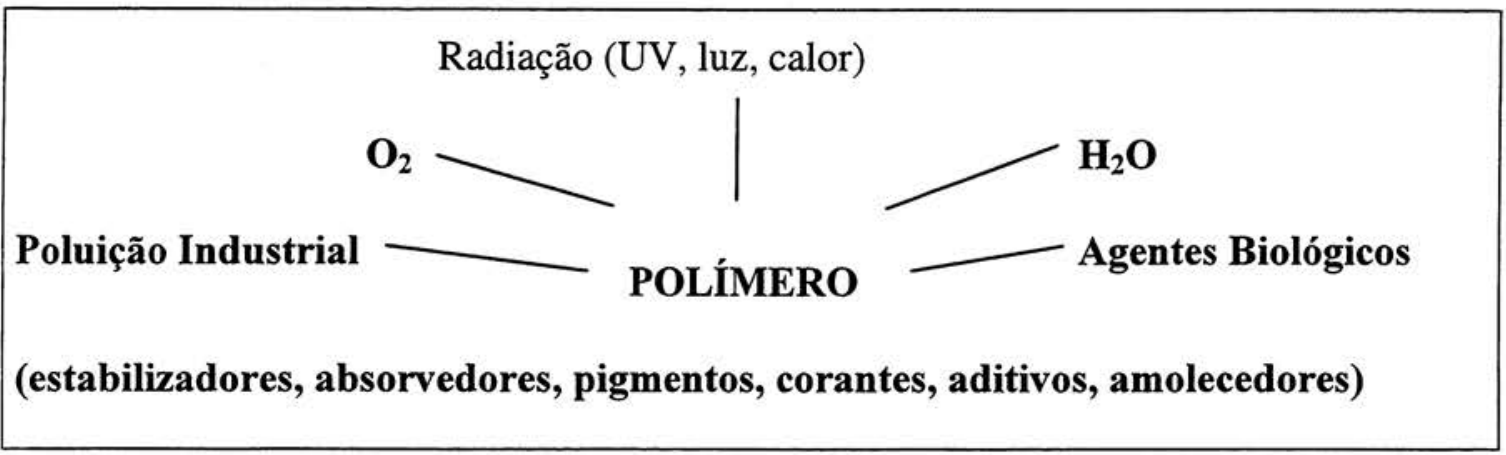

Figura 3. 6 : Os componentes dos polímeros e os fatores de intemperismo (KOCKOTT, 1989)

Estes materiais contêm em sua composição grande número de aditivos com diferentes funções, os quais também são afetados pelos efeitos citados. Por exemplo, o uso de fotoestabilizadores pode aumentar a vida útil de um material polimérico em um fator maior do que dez. Para diferentes compostos macromoleculares contendo outros constituintes a influência de fatores ambientais atua de modo diferente. Por isso, a previsão do comportamento ao longo do tempo destes materiais é uma tarefa difícil, principalmente quando se tenta fazer uma previsão de durabilidade para 20 anos (FELDMAN, 1989).

O fenômeno de degradação envolve ruptura de ligações da cadeia principal que é a espinha dorsal da macromolécula. Em polímeros lineares como as emulsões acrílicas este tipo de reação leva à redução da massa molecular, isto é, uma diminuição do comprimento da cadeia. Quimicamente a degradação envolve a deterioração da funcionalidade dos materiais poliméricos e quanto às propriedades físicas ocorre a 
ruptura das ligações da espinha dorsal além de ocorrerem em modificações na cadeia lateral. Com exceção de reações de reticulações, isto é, formação de ligações cruzadas entre moléculas, as reações na cadeia lateral de polímeros lineares afetam em menor extensão propriedades físicas comparativamente às reações na cadeia principal. A formação de ligações de reticulação como no caso da resina epóxi pode ser considerada o oposto da degradação, considerando-se que no primeiro caso há um aumento de massa molecular e dimensão do polímero enquanto que no segundo caso há ruptura de ligações na cadeia principal dos polímeros lineares e redução da massa molecular (FELDMAN, 1989).

Nos materiais poliméricos não só o polímero é afetado mas também os outros constituintes, que, no caso de tintas são os seus pigmentos e aditivos. Os aditivos plastificantes e os biocidas podem ser lixiviados pela água de chuva.

Para os materiais poliméricos os tipos de degradação mais comuns causados pelos agentes do meio são fotodegradação, degradação química, mecânica, térmica e biodegradação (FELDMAN, 1989). Para as pinturas os tipos mais comuns são:

\section{- Fotodegradação}

O polímero sofre modificações químicas e físicas causadas pela ação da radiação U.V. ou a luz visível. Os grupos cromóforos presentes nas macromoléculas ou nos aditivos absorvem U.V. e iniciam-se reações fotoquímicas. O material torna-se quebradiço e há alteração de cor. A luz solar que atinge a superfície da terra tem comprimento de onda de 290 a 3.000 nm e os grupos cromóforos absorvem na faixa de U.V., isto é, em comprimento de onda abaixo de $400 \mathrm{~nm}$. O efeito fotoquímico é o parâmetro decisivo na degradação dos polímeros, e nesse processo o teor de UV entre 300-400 nm é a radiação decisiva. 
- Degradação química

É ocasionada por agentes químicos do meio, sendo os mais comuns o oxigênio resultando em reações de oxidação, a água causando a hidrólise e os ácidos causando a acidólise dos polímeros. Existe uma grande dependência destas reações com a temperatura, assim como os efeitos destes agentes se sobrepõem.

- Biodegradação

Está relacionada com degradação química causada por ataque microbiológico. Os microrganismos produzem uma variedade de enzimas que reagem com os polímeros.

A temperatura é importante nos fenômenos de degradação. Em polímeros amorfos e semicristalinos, a temperatura de transição vítrea $(\mathrm{Tg})$ tem grande influência, pois a mobilidade das cadeias e dos radicais livres aumentam acima do valor de $\mathrm{Tg}$ e, simultaneamente, a difusão de gases como oxigênio ocorre com maior velocidade. Além disso, em temperaturas acima do valor da $\mathrm{Tg}$ o polímero ainda tem maior volume livre (DANIELS, 1989). O efeito na velocidade de degradação depende do material e do processo de degradação específica.

Conforme citado anteriormente, pelo fato das tintas terem como um dos constituintes principais os polímeros, a sua resistência aos agentes do meio depende basicamente do tipo desses polímeros, da microestrutura deles e da formulação das tintas. Qualquer que seja a microestrutura, o polímero sólido consiste de um emaranhado de cadeias. 
As pinturas, quando expostas à radiação solar, à umidade e à temperatura elevada, sofrem transformações na composição química; há alteração das propriedades físicoquímicas e mecânicas tais como coloração, brilho, calcinação ${ }^{11}$, aparecimento de fissuras, aumento de porosidade da película etc. A previsão da vida útil de uma pintura é um parâmetro importante nos fenômenos de transporte de massa pelo fato das alterações observadas modificar a velocidade de penetração do agentes presentes na atmosfera ao interior do concreto.

A exposição ao ar ou a um meio oxidante leva à formação de ligações cruzadas por meio do oxigênio (MANO, 1991): as moléculas ficam ligadas de forma que a deformação elástica é dificultada. A película de tinta aplicada no concreto ao longo do tempo perde flexibilidade, torna-se rígida e quebradiça, e não consegue acompanhar os movimentos de contração e expansão da base resultando no aparecimento de microfissuras. A resistência à tração na ruptura ${ }^{12}$ ou tenacidade e alongamento na ruptura $^{13}$ são propriedades mecânicas comuns para obter-se informações sobre a durabilidade dos materiais poliméricos. Estas propriedades estão relacionadas com a capacidade da pintura em acomodar-se às tensões existentes em um edifício em movimentação devido às ações higrotérmicas ou do vento.

A velocidade de degradação depende das características do meio no qual está exposta a pintura e da susceptibilidade da tinta decorrente da sua composição química e microestrutura, da cor dos pigmentos e do tipo de acabamento, brilhante ou fosco. As tintas acrílicas com solvente aquoso por serem mais porosas tem maior facilidade à

\footnotetext{
${ }^{11}$ Depósito esbranquiçado e pulverulento formado na superfície do filme causada pela sua degradação. ${ }^{12}$ É avaliada pela carga aplicada ao material por unidade de área, no momento da ruptura (MANO, 1991). ${ }^{13}$ Representa o aumento percentual do comprimento da peça sob tração, no momento da ruptura (MANO, 1991).
} 
penetração de agentes agressivos, à deposição de poluentes do ar e de microorganismos. Além disso, por conterem maiores quantidades de nutrientes provenientes de aditivos estabilizadores e espessantes, que são as celuloses modificadas, ainda são mais susceptíveis a agentes biológicos (MORTON, 1990). Este tipo de tinta quando formulado com alto PVC possui acabamento fosco e textura mais rugosa, facilitando o depósito de sujeiras e de materiais orgânicos, acelerando a sua biodeterioração.

O pigmento também pode sofrer degradação, principalmente os de base orgânica, enquanto que os inorgânicos constituídos por óxidos minerais são mais resistentes.

A função protetora geralmente é muito mais duradoura do que a função decorativa. Muitas vezes uma deterioração superficial altera muito o aspecto da pintura, sendo no entanto mantidas as propriedades como barreira de proteção.

Assim, a durabilidade de uma pintura aplicada corretamente varia em função de uma série de parâmetros como a natureza da tinta, as características do substrato, as condições do meio ambiente e o uso. $\mathrm{Na}$ exposição ao meio ambiente há efeito da radiação solar combinado com os fatores climáticos, agentes biológicos, agentes poluentes, etc. alterando as propriedades do material ao longo do tempo. Os mecanismos são complexos e a ação dos agentes têm efeito sinérgico.

\subsubsection{Metodologia de avaliação da durabilidade}

A previsão da vida útil é difícil de ser efetuada, face aos inúmeros fatores de degradação que interferem na durabilidade do material. Apesar das dificuldades apontadas existem metodologias para o estudo do problema. Faz-se necessário o conhecimento de suas propriedades físicas e químicas, das características do meio ambiente na qual serão utilizadas, bem como dos mecanismos de deterioração em relação às condições de exposição a que estarão submetidas. 
A avaliação da durabilidade de modo geral baseia-se na determinação das suas propriedades antes e após envelhecimento natural e acelerado, ou sob condições de uso simuladas, de forma que possa ser previsto o seu comportamento ao longo do tempo. Conforme MARTIN et al. (1996) os dados necessários para previsão do comportamento ao longo do tempo podem ser gerados através de:

- ensaios acelerados sob condições de uso simuladas;

- exposição em estação de envelhecimento natural ou em uso (serviço);

- estudos dos mecanismos fundamentais.

Nos ensaios acelerados e nos estudos de mecanismo é possível controlar a dos fatores de intemperismo, gerando resultados experimentais reprodutíveis e informações fundamentais sobre o modo e mecanismo de falha da pintura, enquanto que, nos estudos de longa duração em serviço pode-se assegurar uma degradação real, no entanto, raramente fornece informações sobre a causa e o fator que levou à ocorrência da falha.

A análise da árvore de falha ${ }^{14}$ é uma ferramenta importante para a previsão da vida útil de pinturas. É uma técnica de análise dedutiva a qual fornece uma estrutura formal relacionando graficamente e logicamente as falhas básicas com as falhas da raiz. Na Figura 3.7 é ilustrada a árvore de falhas de um sistema de pintura de edifícios (MARTIN et al.; 1996). As falhas do sistema de pintura podem ser atribuídas a um número de falhas na raiz as quais estão associadas a técnicas de aplicação, projeto da estrutura a ser pintada, fabricação do produto, propriedades do material e condições do meio ambiente. As falhas da raiz ainda podem ser subdivididas em subfalhas até chegar na falha básica que é definida como limite de resolução da causa de uma falha.

\footnotetext{
${ }^{14}$ A técnica de análise da árvore de falhas parte do efeito e analisa os modos e causas prováveis de falhas.
} 


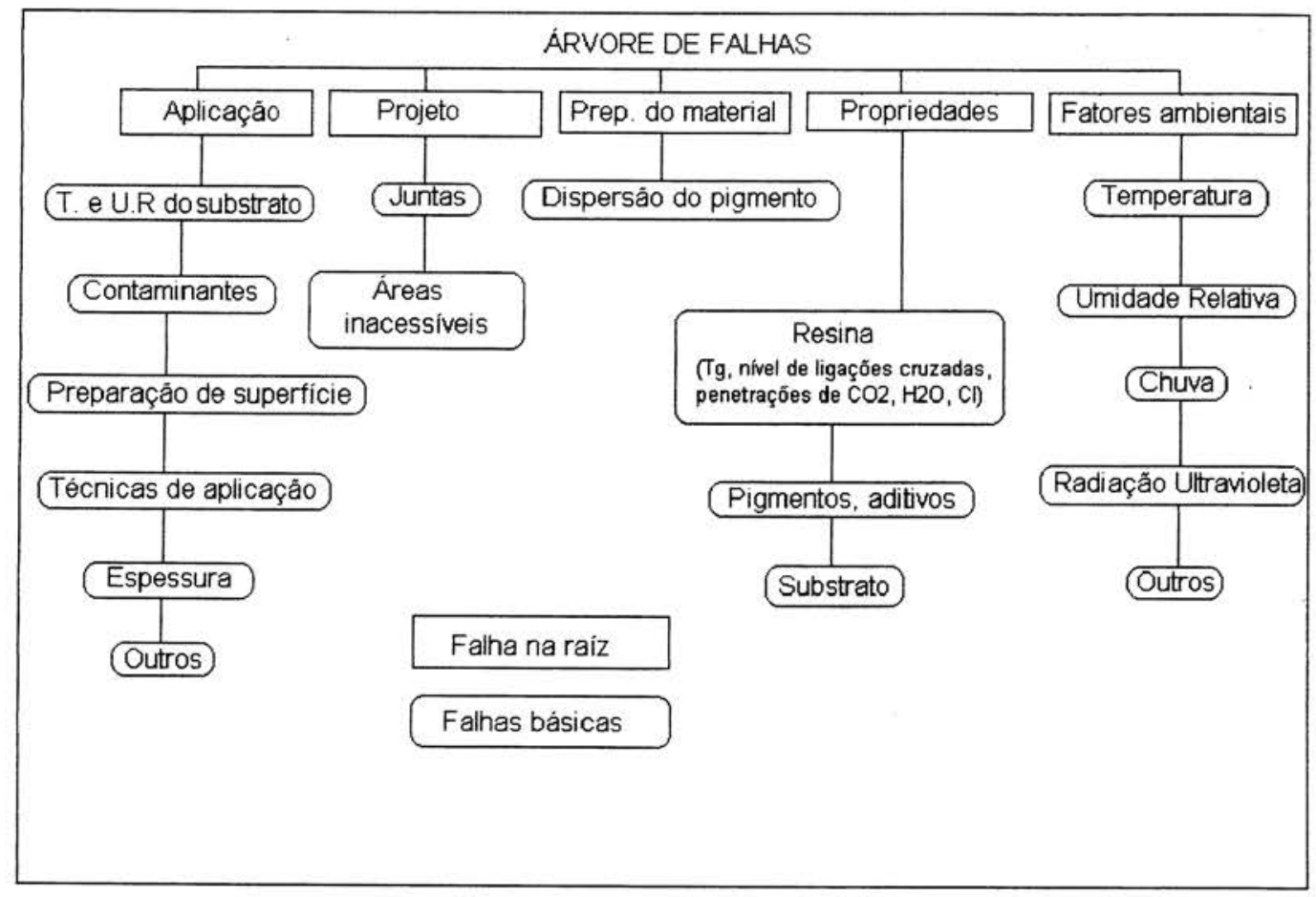

Figura 3. 1 : Falhas comuns (raiz e básicas) associadas a sistemas de pintura de edifícios (MARTIN et al.; 1996)

A metodologia sugerida por FLAUZINO (1983) válida até hoje, amplamente discutida na sua dissertação de mestrado, teve como diretrizes a norma da ASTM E 632-82 (1988) 'Practice for developing accelerated tests to aid prediction of the service life of building components and materials" para a avaliação de materiais e componentes de construção civil e, foi especialmente adaptada para avaliação de pinturas, conforme discutido nos itens a seguir:

a) definição dos requisitos de desempenho, isto é, identificação das suas propriedades mais significativas para que possa cumprir suas funções decorativas e/ou de pré 
definição dos requisitos de desempenho, isto é, identificação das suas propriedades mais significativas para que possa cumprir suas funções decorativas e/ou de proteção como:

- proteger a base contra a penetração dos agentes agressivos como a água, a névoa salina, o anidrido carbônico, etc.;

- manter a estética não alterando em serviço a cor, o brilho, não apresentar manchas, empolamentos, fissuras, descolamentos, etc.

b) identificação dos indicadores de degradação, que podem ser propriedades físicas, químicas, mecânicas ou de aparência a serem medidas como por exemplo:

- variação da permeabilidade da película aos agentes do meio;

- variação da resistência mecânica como a aderência, dureza, flexibilidade, etc.;

- alteração do aspecto como cor, brilho, manchas causadas por fungos, umidade, eflorescência, fissuras, etc.

c) identificação dos agentes de degradação, que são aqueles agentes do meio ambiente desde os climatológicos até os presentes no substrato.

$\Rightarrow$ agentes do intemperismo (atmosfera) natural:

- radiação solar, principalmente a U.V. que é a mais agressiva aos materiais orgânicos;

- temperatura, principalmente as variações cíclicas;

- água na forma de chuva, vapores do meio, condensação, neblina, névoa salina.

- gases como o $\mathrm{O}_{2}$ e $\mathrm{O}_{3}$;

- agentes de poluição como os gases ácidos contendo $\mathrm{SO}_{2}, \mathrm{SO}_{3}, \mathrm{NO}_{2}$; 
- partículas ácidas, poeiras;

- agentes biológicos como as algas, fungos, musgos, bactérias.

$\Rightarrow$ agentes químicos presentes em ambientes internos de indústrias químicas como os ácidos sulfúrico, nítrico, clorídrico, láctico, os solventes, etc.;

$\Rightarrow$ agentes agressivos provenientes do substrato como a alcalinidade do concreto fresco e resinas exsudadas de madeiras resinosas.

d) identificação dos possíveis mecanismos, que no caso dos revestimentos externos são aqueles causados pela ação conjunta dos agentes listados anteriormente, prejudicando a estética e a salubridade do edifício, como no caso a presença de microrganismos biológicos.

e) definição do programa de ensaios, que se baseia na determinação das propriedades do sistema pintura/substrato, consideradas relevantes, sem e após envelhecimento natural ou artificial.

- envelhecimento artificial: são ensaios realizados sob condições de uso simuladas e de modo acelerado. Têm sido realizados através da exposição do revestimento estudado em câmaras onde se empregam condições não encontradas na natureza, consequentemente, nem sempre reproduzem processos de degradação real, mas têm a vantagem de serem realizados em condições controladas e padronizadas em qualquer lugar do mundo. Os tipos mais comuns são: câmara de condensação/UV, névoa salina, etc.;

- exposição em estação de envelhecimento natural: o ensaio pode ser realizado sob condições normais de uso ou condições que favoreçam maior incidência da radiação U.V. ou permanência de água. A exposição em diferentes estações não permite 
condições padronizadas devido às diferenças climáticas que variam de uma região para outra.

f) avaliação dos resultados, a partir dos resultados obtidos nos ensaios, sem e após envelhecimento natural ou artificial avalia-se o estado da pintura:

- comparando-se os resultados obtidos com os requisitos propostos que podem ser avaliações quantitativas ou qualitativas, que são mais subjetivas usando padrões fotográficos com os defeitos típicos, como no caso de grau de ferrugem, empolamento, craqueamento, calcinação, erosão, etc.;

- correlacionado-se os resultados da exposição natural e acelerado por meio da realização de ensaios físicos.

\subsection{Influência da porosidade nas propriedades de transporte}

Os materiais quando expostos ao intemperismo sofrem degradação devido a ação de vários mecanismos de transporte complexos interligados e quase sempre inseparáveis. Os principais mecanismos de transporte são: a difusão gasosa, a permeabilidade e a absorção capilar, e estes ocorrem em função da dimensão e da forma da estrutura dos poros dos materiais; e este é o meio por onde penetram os agentes agressivos do ambiente.

A análise das interrelações entre a estrutura do poro e coeficiente de transporte baseia se hoje em um novo conceito; por razões físicas e químicas a natureza do processo de transporte de massa depende da faixa de dimensão do raio do poro, conforme ilustrado na Figura 3. 8 (MENG, 1994). A Figura mostra a relevância da dimensão do poro nos fenômenos de transporte; observa-se que, a difusão gasosa ocorre em poros com raios 
maiores do que $0,001 \mu \mathrm{m}$, a absorção capilar em poros entre $0,1 \mu \mathrm{m}$ a $1000 \mu \mathrm{m}$ e a permeabilidade em poros maiores do que 0,1 . Os poros são classificados em:

- macroporos, poros $>0,050 \mu \mathrm{m}$

- mesoporos; poros entre 0,002 a 0,050

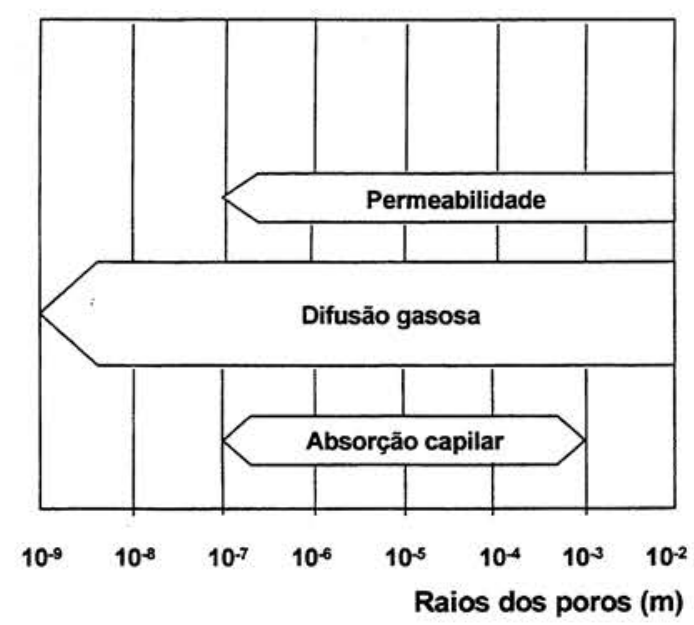

Figura 3. 8 : Influência da faixa de dimensão dos raios dos poros nos fenômenos de transporte (MENG, 1994).

A porosidade de qualquer material sólido é definida como sendo a razão entre o volume dos poros e vazios deste material em relação ao seu volume total (ADDLESON, 1972), isto é, qualquer espaço entre as microunidades é maior do que as dimensões atômicas da molécula de água ou de outro gás qualquer. Por exemplo, a molécula de água tem $35 \mathrm{~nm}$ ${ }^{15}$ de diâmetro, dessa forma, ela penetra em qualquer poro com dimensão maior do este valor (SEREDA, 1970). Como os poros geralmente possuem tamanhos superiores às dimensões moleculares os agentes presentes no meio ambiente conseguem penetrar nos materiais e causar a sua deterioração.

\footnotetext{
${ }^{15}$ Valor obtido com base no raio atômico.
} 
A medida da porosidade isoladamente nem sempre tem uso prático pois não fornece informação suficiente quanto à estrutura dos poros dos materiais pois, em muitos casos, as propriedades desses dependem muito mais do arranjo dos seus poros, isto é, da dimensão e forma dos poros, que podem serem fechados não passantes ou abertos passantes, interligados e formando canais (ADDLESON, 1972) do que da quantidade de poros. As propriedades físicas e mecânicas dos materiais são influenciadas pela natureza de suas microunidades, de suas formas e dimensões.

A Figura 3. 9 ilustra os vários tipos de poros, com base na classificação da norma BS 7591: Part4: 1993).

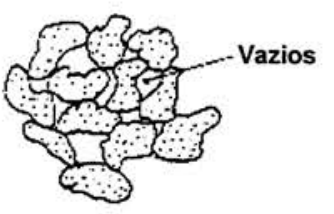

a) Vazios entre particulas

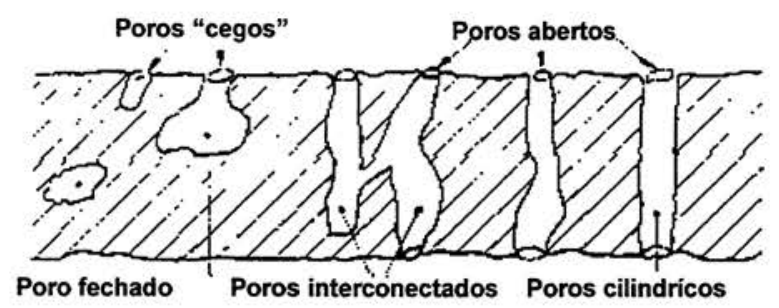

b) Tipos de poros

Figura 3. 9 : Classificação dos tipos de poros (BS 7591: Part4: 1993).

A caracterização detalhada da estrutura dos poros envolve a utilização de várias técnicas de medida e observação, pois cada uma delas fornece um tipo de informação e inclusive a faixa de dimensão do poro. O detalhamento do processo de determinação destes dados, bem como maiores comentários estão no item 4.3.4. 


\section{PLANEJAMENTO DA PESQUISA}

\subsection{Introdução}

O estudo foi estruturado a partir de revisão bibliográfica e de pesquisa de mercado, com o objetivo de conhecer os sistemas de pintura mais utilizados, para a proteção de estruturas de concreto, e também de conhecer os resultados experimentais já obtidos, a respeito das técnicas de caracterização e avaliação desses materiais, e desempenho desses sistemas com relação às propriedades de transporte de massa.

A revisão bibliográfica mostrou a ausência de informações quanto à correlação entre a formulação da tinta e as características de desempenho e propriedades de transporte de massa. Os estudos publicados mostram que tintas de um mesmo tipo de veículo, mas com diferentes teores de sólidos, não apresentam a mesma absorção de água por capilaridade (PFEIFER; SCALI, 1981). Esses estudos foram realizados com sistemas de pintura de diferentes tipos de resina, obtidos no mercado ou fornecidos por fabricantes de tinta, não existindo dados quanto à influência da formulação na proteção do concreto contra a corrosão de armadura. Os resultados obtidos para uma determinada amostra são restritos a ela; os estudos indicam o tipo de veículo mas não informam detalhes da composição da tinta. A revisão da literatura também mostrou que um dos polímeros mais estudados atualmente é a resina acrílica elastomérica, de base aquosa, com $\mathrm{Tg}$ inferior a zero graus centígrados.

Esses dados mostraram a importância da realização de estudo com tintas de composição conhecida, todas preparadas com um mesmo veículo, mas formuladas variando-se as relações entre o pigmento e veículo, preparadas com base nas relações de $P V C$ usuais em tintas do mercado. Esses dados também direcionaram a seleção da composição básica da tinta do estudo, tendo sido escolhida a resina acrílica. 
Para que a pesquisa representasse os materiais possíveis de serem comercializados também foram realizados contatos com fabricantes de tintas imobiliárias para a definição da formulação. Os contatos mostraram que um dos polímeros mais utilizados no mercado nacional para fins de proteção de fachadas de concreto, de edifícios residenciais e comerciais, é a resina acrílica copolimerizada com estireno, com solvente aquoso, e que na América do Norte a resina mais utilizada para esta finalidade é a resina acrílica pura com plastificação interna, também com solvente aquoso, analogamente aos dados de literatura. $\mathrm{O}$ concreto recém executado ou exposto à chuva contém elevado teor de água, não permitindo boa penetração da tinta no substrato, sendo que os produtos com solvente orgânico são por isso mesmo menos adequados para concreto úmido do que produtos com solvente aquoso.

Com base nas informações obtidas ficou definido que o estudo seria realizado com amostras de tinta preparadas em laboratório, variando-se especificamente a relação volumétrica de pigmentos $(P V C)$ previamente estabelecida. Foi realizada uma avaliação exploratória da formulação que teve como referência as amostras de tinta à base de resina estireno/acrílica, com os mesmos PVCs. Como os sistemas de pintura nos projetos são escolhidos pelo tipo de acabamento, selecionaram-se formulações que resultassem em acabamentos semi-brilho ou fosco, que são as usuais do mercado para edificações. A variação na relação de $P V C$ significa na prática a obtenção de produtos com acabamentos de aspecto diferenciado: brilhante, semi-brilho ou fosco. Foi incluído no estudo o verniz (PVC 0\%) a fim de se obter uma indicação sobre a durabilidade da resina isoladamente, sem a influência do pigmento. 


\subsection{Definição da formulação da tinta}

A definição teve como objetivo principal avaliar os fatores que interferem no transporte de massa, estudando especificamente a influência da porosidade de diferentes formulações de tinta quanto à penetração de agentes agressivos como o $\mathrm{CO}_{2}$, íon cloreto e de agentes intervenientes como a água e vapor de água quando aplicadas em concretos de baixa e elevada porosidade.

O estudo foi subdividido em duas fases:

- a primeira fase, exploratória, de determinação das características do polímero e dos PVCs escolhidos no preparo das amostras e,

- a segunda fase, de estudo dos fenômenos de transporte de massa, com tintas formuladas especialmente segundo indicação de fabricantes.

\subsubsection{Primeira fase: Estudo exploratório}

As tintas à base de resina "acrílica pura"16 foram preparadas com PVC de $50 \%$ e de $30 \%$ e as tintas à base de resina estireno/acrílica foram preparadas com PVC entre $50 \%$ e $0 \%$. As amostras com PVC de 50\% são constituídas por tintas com maior teor de pigmentos do que $P V C$ de $30 \%$ e a amostra de $P V C$ igual a zero \% é, na verdade, um verniz que é um revestimento sem pigmentos. Foi preparado maior número de formulações para a resina estireno/acrílica com o objetivo de se verificar a influência do teor de pigmentos, principalmente do dióxido de titânio, na resistência à radiação ultravioleta. As duas resinas em questão são originárias de um mesmo fabricante e todas as tintas foram preparadas no laboratório de um único fabricante de tinta. Na Tabela 4.1 estão relacionadas as amostras estudadas.

\footnotetext{
${ }^{16}$ A caracterização por espectrofotometria no infravermelho mostrou que esta resina é um copolímero de poli(acrilato) com estireno.
} 
Tabela 4. 1 : Amostras estudadas

\begin{tabular}{|l|c|c|}
\hline Tipo de resina & Tipo de acabamento & PVC \% \\
\hline \multirow{4}{*}{ "Acrílica pura" } & semi - brilho & 30 \\
\cline { 2 - 3 } & fosca & 50 \\
\hline \multirow{4}{*}{ Estireno/acrílica } & semi - brilho & 0 \\
\cline { 2 - 3 } & semi - brilho & 10 \\
\cline { 2 - 3 } & semi - brilho & 20 \\
\cline { 2 - 3 } & semi - brilho & 30 \\
\cline { 2 - 3 } & fosca & 50 \\
\cline { 2 - 3 } & & \\
\cline { 2 - 3 }
\end{tabular}

\section{a) Avaliação preliminar}

Para verificar se as amostras de tinta apresentavam características semelhantes aos produtos disponíveis no mercado foram programados alguns ensaios prévios para uma avaliação preliminar do seu desempenho, como também verificar se as formulações usadas eram adequadas para a continuação do estudo. Os ensaios químicos realizados foram os normalmente utilizados para verificar a composição e controle de uniformidade de lotes, e além disso, determinadas a resistência à lavabilidade e a temperatura mínima de formação de filme, adotados como indicadores de desempenho.

\section{b) Conclusão}

O estudo exploratório permitiu concluir que as tintas acrilicas puras após a cura, em ambiente de laboratório, e envelhecimento acelerado, resultaram em películas rígidas $e$ quebradiças. Pelo fato dos resultados obtidos não terem sido considerados satisfatórios houve necessidade de redirecionamento da pesquisa. 


\subsubsection{Segunda fase: Formulação estudada}

Os conhecimentos adquiridos no estudo preliminar mostraram que a resina acrílica pura usada, com $\mathrm{Tg}$ ao redor de $30^{\circ} \mathrm{C}$, apresentava características inadequadas para a formulação de tintas de aplicação em substratos como o concreto, onde há necessidade de propriedades elásticas, para melhor acomodação dos efeitos de contração e expansão desse substrato, e além disso, os PVCs escolhidos não representavam aqueles usuais do mercado.

Optou-se pela investigação de tintas preparadas com resina acrílica mais macia ${ }^{17}$, o que pode ser obtido por meio de polímeros de $\mathrm{Tg}$ inferior ao estudado na primeira fase. Uma referência relevante é a de SWAMY; TANIKAWA (1990) que estudou tintas à base de polímero acrílico elastomérico, de $\mathrm{Tg}$ inferior a $0^{\circ} \mathrm{C}$. Pelo fato de não ter sido encontrado fabricante de resina acrílica pura no mercado brasileiro, com valores de $\mathrm{Tg}$ inferior a zero, os estudos foram continuados com resina acrílica pura importada da Alemanha, com $\mathrm{Tg}$ ao redor de $20^{\circ} \mathrm{C}$, portanto, uma resina mais macia que a resina utilizada no estudo exploratório.

Ficou decidido que as novas amostras de tinta seriam preparadas com $P V C$ na faixa do acabamento semi-brilho existente no mercado, que compreende PVCs de $25 \%$ a $40 \%$ (inferior ao $C P V C$ ), e na faixa do acabamento fosco do mercado que compreende $P V C s$ de $60 \%$ a $75 \%$ (superior ao $C P V C$ ), e o verniz com $P V C$ de $0 \%$, devido à ausência de pigmentos na formulação. As amostras foram preparadas com fórmula-proposta, fornecidas pelo fabricante de polímero, e indicadas para o preparo de tintas estirenoacrílicas.

\footnotetext{
${ }^{17}$ Resina macia significa polímero que resulta em películas de baixo módulo de elasticidade. Termo utilizado pelos fabricantes de tintas e de polímeros.
} 


\subsection{Programa experimental}

\subsubsection{Preparação dos substratos de concreto}

Tendo como objetivo o estudo dos fenômenos de transporte de massa em concretos de baixa e elevada porosidade, com e sem película de proteção, foram adquiridos no mercado cimento, areia e brita como matéria prima para o preparo dos corpos-de-prova a serem usados como referência no estudo.

\section{a) Caracterização dos materiais}

Os materiais (cimento, areia e brita) usados no preparo dos substratos de concreto, foram caracterizados conforme normas brasileiras.

\section{b) Preparação e moldagem dos concretos}

Foi levantada a curva de dosagem experimental para a determinação dos traços de concreto e moldagem em forma de painéis, visando a obtenção de superfície que simula o acabamento do concreto obtido em obra e conforme os traços definidos na dosagem.

\subsection{Caracterização dos polímeros}

Os polímeros foram caracterizados conforme os ensaios listados abaixo, para a correlação de suas características com desempenho e durabilidade das tintas.

\section{a) Identificação da composição}

Uma substância química pode ser identificada qualitativamente, por espectrofotometria no infravermelho, pelo tipo de ligação covalente existente nos grupos funcionais, por exemplo, as ligações $\mathrm{C}=\mathrm{C}, \mathrm{N}-\mathrm{H}, \mathrm{C}-\mathrm{N}, \mathrm{C}=\mathrm{O}, \mathrm{O}-\mathrm{H}$. 
As ligações químicas podem ser excitadas por meio de radiações eletromagnéticas na região do infravermelho; parte da energia aplicada é absorvida por estas ligações e através da alteração da quantidade de energia aplicada obtêm-se espectros de infravermelho do material a ser identificado. Conforme WUNDERLICH (1993), o espectro de infravermelho representa as bandas de absorção, também chamada de impressão digital, e permite a caracterização da estrutura do composto.

Os espectros das resinas, as bandas de absorção, foram obtidos em espectrofotômetro com transformada de Fourier (FTIR) ${ }^{18}$, marca Nicolet, modelo Protegé 460 . A técnica consiste na obtenção do espectrograma da resina e identificação por comparação com espectro padrão ou de referência, do banco de espectros para pesquisa, da biblioteca de padrões do Hummel de polímero e aditivos, usando o programa OMNIC 3.1a.

\section{b) Temperatura de transição vítrea (Tg)}

As análises térmicas medem mudanças de propriedades físicas e químicas em função de aumento ou diminuição de temperatura. A $\mathrm{Tg}$ foi determinada por calorimetria de varredura (exploratória) diferencial, em um equipamento Perkin Elmer, modelo 3700 Data Station. A técnica consiste na medida da variação de fluxo de calor entre uma amostra de estudo e a de referência, em uma mesma velocidade, e, qualquer diferença de temperatura entre ambos resulta em um fluxo de calor que é exatamente proporcional à esta diferença.

\section{c) Temperatura mínima de formação de filme (TMFF)}

É a temperatura abaixo da qual a película não se forma de maneira adequada. Ela depende da composição do polímero, isto é, da sua Tg e da presença de adições como

\footnotetext{
${ }^{18}$ No infravermelho dispersivo as freqüências são medidas sucessivamente, enquanto que na FTIR as freqüências são medidas simultaneamente, resultando em maior sensibilidade e velocidade de medida.
} 
plastificantes, coalescentes, colóide, etc. Esta determinação mede indiretamente a Tg e, por isso, muitas vezes é confundida com esta propriedade.

O ensaio foi realizado conforme diretrizes da norma ASTM D 2354-91 em equipamento de medida de "Minimum Film Formation Temperature" (MFFT)- Bar.60, marca Gardco, à temperatura ambiente de $25^{\circ} \mathrm{C}$ e umidade relativa de $70 \%$, em 3 condições de escala de temperatura de calor/frio $\left(18^{\circ} \mathrm{C}\right.$ a $4^{\circ} \mathrm{C} ; 13^{\circ} \mathrm{C}$ a $-5^{\circ} \mathrm{C}$ e $50^{\circ} \mathrm{C}$ a $\left.23^{\circ} \mathrm{C}\right)$ e extensor com vão de $75 \mu \mathrm{m}$.

\section{d) Tamanho médio e distribuição das partículas}

A dimensão das partículas de polímeros influi na capacidade de aglomeração do pigmento e na formação de filme; esta característica não afeta a viscosidade da emulsão, pois, a dimensão média elevada de partículas está associada a baixa viscosida (FRIEL, 1995). O tamanho médio e a sua distribuição foram determinadas em um equipamento de marca Malvern, modelo Autosizer IIc, pela técnica de espectroscopia de correlação fotônica. O princípio do método consiste na passagem de um feixe de raio laser através de uma suspensão de partículas sem haver interação.

\subsubsection{Caracterização e avaliação preliminar do desempenho das tintas}

\section{a) Ensaios de caracterização química}

As tintas foram caracterizadas quanto aos teores de sólidos, de veículo (perda de massa a $450^{\circ} \mathrm{C}$ ) e de pigmentos, conforme a norma ASTM D-3723. Os resultados obtidos dão indicações quanto aos teores relativos de solvente, que neste caso é a água, de veículo (resina) e de pigmentos. Os valores obtidos não fornecem a quantidade real destes constituintes devido à limitação do método utilizado, mas, permitem controlar a uniformidade entre os lotes de produtos e são usados para a aceitação e recebimento de 
amostras. As quantidades reais de resina e pigmento são aquelas obtidas por cálculo e apresentados na Tabela 5.2.

\section{b) Resistência à lavabilidade}

Este ensaio teve por objetivo verificar se as tintas acrílicas puras, de desempenho desconhecido, preparadas com as fórmulas-proposta para tintas estireno-acrílicas, apresentam desempenho dentro dos padrões aceitos pelos fabricantes de tinta. A lavabilidade das tintas foi determinada conforme a norma ASTM D- 2486-89, a qual mede a resistência, de películas de tinta, à lavagem e ao esfregamento; indiretamente, mede também a força de coesão entre. as partículas de pigmento. De modo geral, tintas formuladas com teores insuficientes de veículo apresentam baixa resistência à lavabilidade.

\section{c) Temperatura mínima de formação de filme}

Já discutido anteriormente. Pode-se acrescentar que, na tecnologia das emulsões, que para as tintas objeto do estudo, a formação do filme é um fenômeno de elevada importância. O ensaio realizado permite verificar qual é a temperatura mínima necessária para que a tinta forme um filme contínuo e uniforme.

\section{d) Permeabilidade ao vapor de água}

Este ensaio permite determinar a velocidade na qual o vapor de água atravessa a película de pintura livre, sem a influência do substrato. A determinação teve por objetivo verificar a influência da variação do $P V C$ de tintas, à base de resina acrílica pura e estireno/acrílica, nesta propriedade. O ensaio foi realizado conforme a norma ASTM 1653-91a, expondo os corpos-de-prova em uma câmara climática, nas condições de umidade e temperatura recomendadas por esta norma. Nas Figura 4 . 1 e Figura 4. 2 estão ilustradas a câmara e os corpos-de-prova pintados usados na realização do ensaio. 


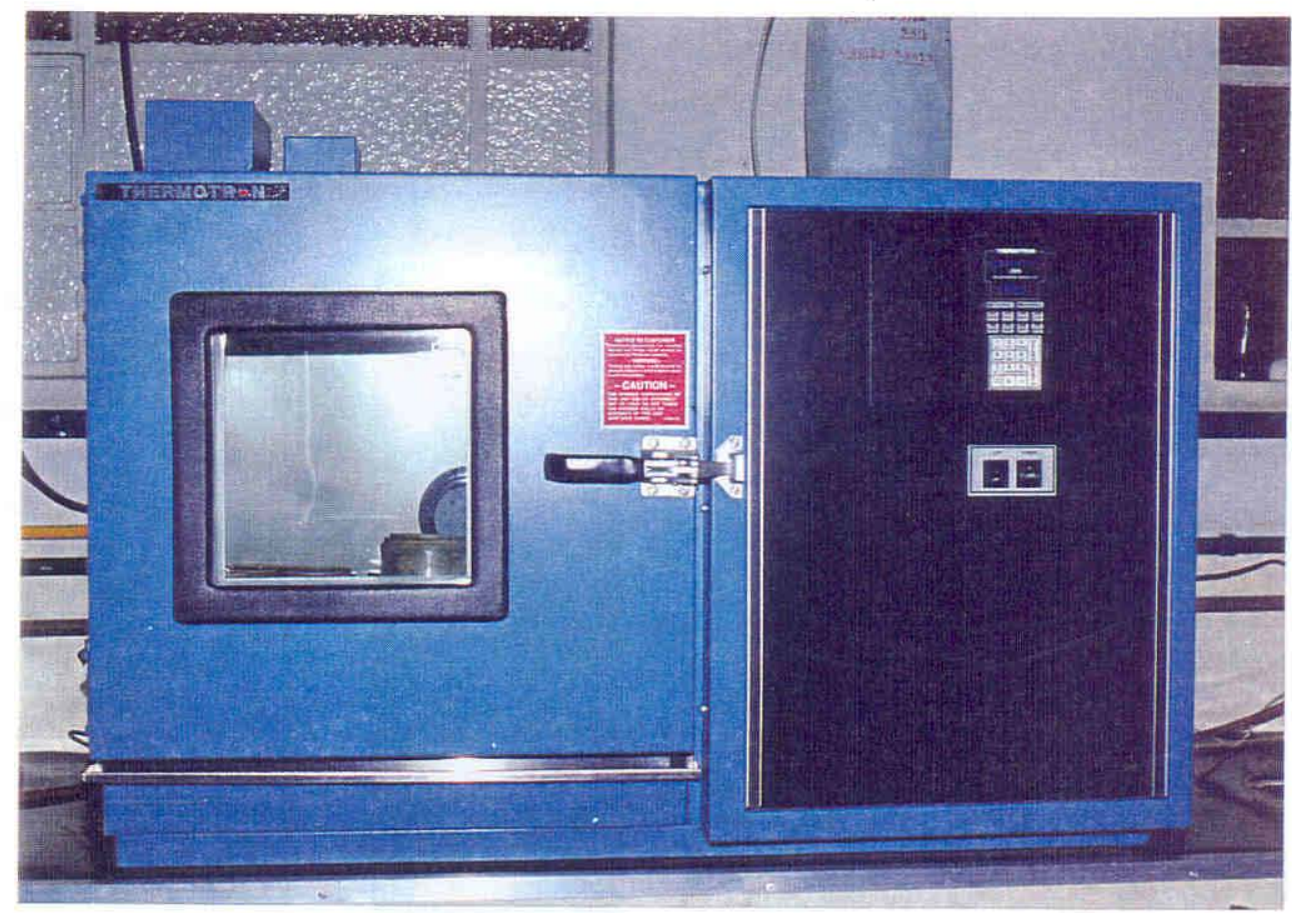

Figura 4. 1: Câmara climática usada na determinação da permeabilidade ao vapor de água.

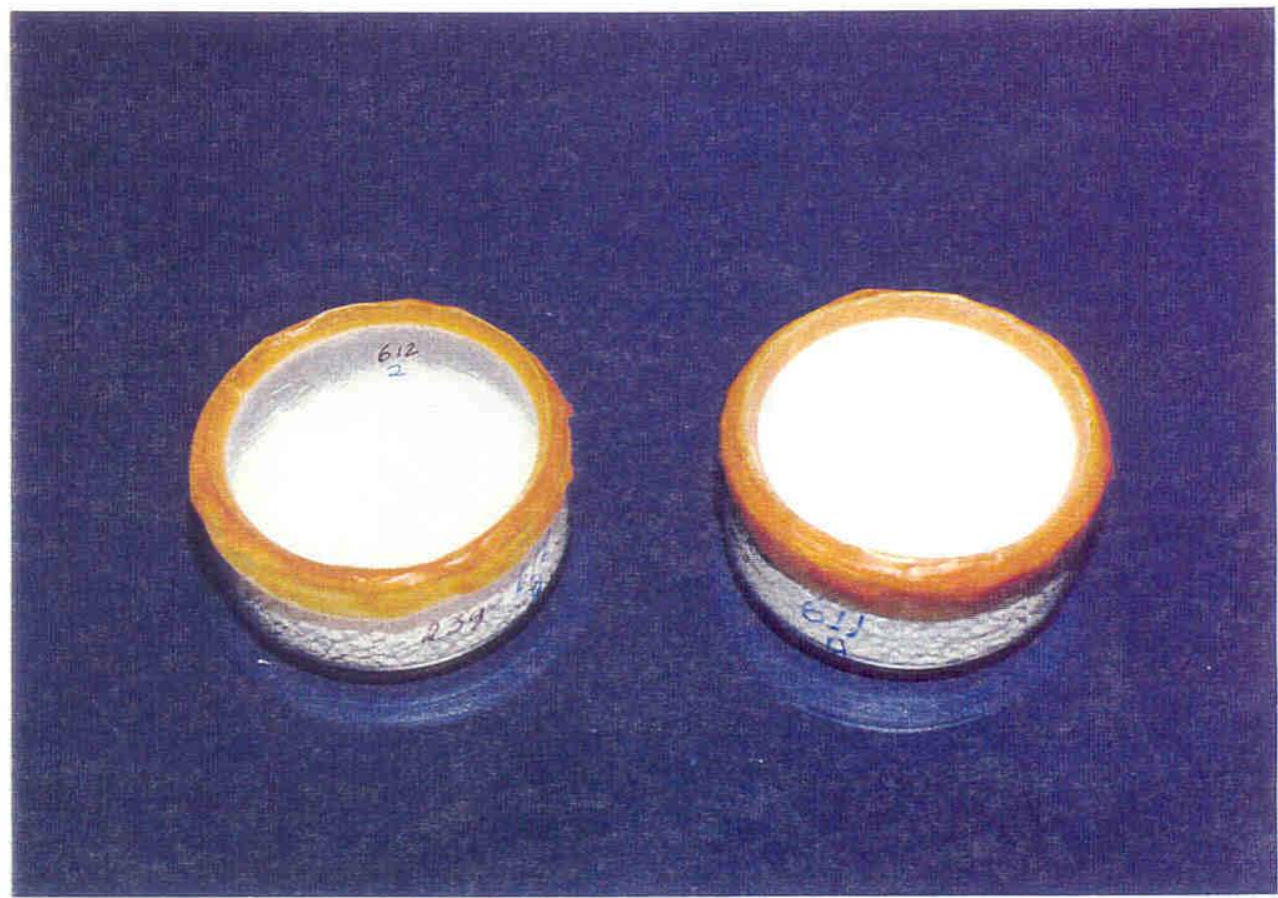

Figura 4. 2 : Corpos-de-prova usados na determinação da permeabilidade ao vapor de água. 


\section{e) Envelhecimento acelerado}

A durabilidade foi verificada expondo películas livres de pintura em câmara, com ciclos alternados de: 4 horas ao ultra violeta (UV-B), com temperatura de $60^{\circ} \mathrm{C} ; 4$ horas de condensação, com temperatura de $50^{\circ} \mathrm{C}$, durante 300 e 600 horas. $\mathrm{O}$ ensaio foi realizado conforme a norma ASTM G 53-89, e os dois períodos de exposição, de 300 h para o verniz e $600 \mathrm{~h}$ para tintas látex, foram escolhidos com base na proposta da norma da CE-02:002.29-Comissão de Estudo de Tintas para Edificações não Industriais da ABNT-Associação Brasileira de Normas Técnicas.

Para estudar a evolução do envelhecimento foram consideradas relevantes, nesta pesquisa, características como o aspecto, o brilho e a cor. As propriedades físicas que descrevem o aspecto dos materiais são importantes como indicadores de degradação do processo de envelhecimento ( RILEM, 1981), principalmente pelo fato das pinturas serem usadas em fachadas de edifícios. As alterações observadas, após exposição na câmara, foram determinadas comparativamente aos corpos-de-prova sem exposição conforme os ensaios descritos a seguir:

- Alteração do brilho

O método de avaliação consiste em dirigir um feixe de luz de um determinado ângulo sobre a superfície, e medir a intensidade do feixe refletido, com uma célula fotoelétrica. O ensaio foi realizado conforme a norma ASTM - D 523-89 com um medidor de brilho, marca Byk-Gardner, Inc., com angulo de $60^{\circ}$.

- Alteração da cor com base na escala cinza

A avaliação colorimétrica visual foi realizada conforme as diretrizes da norma ASTM D 2616, com auxílio da escala cinza, sob luz artificial $\mathrm{D}_{65}$, em câmara-padrão de 
observação, posicionados em frente aos corpos-de-prova e com ângulo de observação visual de $45^{\circ}$.

- Alteração da cor por colorimetria instrumental computadorizada

Foi determinada por método instrumental, em um colorímetro computadorizado, marca Macbeth. Como a principal alteração de cor observada era o amarelecimento das películas também foi medido este índice, conforme a norma ASTM E 313-73 (1993), neste mesmo equipamento.

Condições de ensaio

$\Rightarrow$ Área de medida no corpo-de-prova : $0,5 \mathrm{~mm}^{2}$.

$\Rightarrow$ Iluminante primário $\mathrm{D}_{65}$

\subsubsection{Ensaios de desempenho}

A intensidade de degradação do concreto depende da velocidade de penetração de substâncias agressivas ao seu interior. A estrutura e distribuição do tamanho dos poros do concreto são alguns dos fatores que mais influenciam os mecanismos de transporte de agentes agressivos. Normalmente os poros são classificados em microporos, poros capilares e macroporos (ar aprisionado e ar incorporado) sendo os dois últimos os de maior relevância em relação à durabilidade do concreto (CEB, 1989).

A cinética da penetração de agentes no concreto pode ser modificada pela aplicação de tinta; desta forma uma película que possui dimensões de poros inferiores, funcionando como uma barreira que altera o mecanismo de transporte. Os ensaios de desempenho das tintas estão direcionados de modo a verificar o efeito destes materiais nos poros do concreto. A influência das diferentes formulações de tinta, como barreira de proteção ao concreto, foi estudada realizando-se ensaios que simulam diferentes mecanismos de 
transporte de agentes. Os ensaios foram realizados em corpos-de-prova de concreto, de $\mathrm{fck}=20 \mathrm{MPa}$ e de $\mathrm{fck}=40 \mathrm{MPa}$, pintados e sem pintura, conforme relacionados a seguir:

\section{a) Absorção de água por capilaridade e evaporação de água}

Em geral, a resistência do concreto a agentes químicos e físicos é influenciada pela quantidade de poros capilares, por isso, a importância da determinação da influência da formulação da pintura na absorção capilar do concreto. O método de absorção de água por capilaridade teve como objetivo simular a penetração de água, em fachada exposta à chuva, durante 7 dias consecutivos. $O$ ensaio teve como base as diretrizes apresentadas na norma BS-6477-92 "Water repellents for masonry surfaces, item 5.3 Absorption of water". O procedimento consiste na imersão parcial de corpos-de-prova de concreto, de dimensões de $10 \times 10 \times 2,5 \mathrm{~cm}$, sem e com pintura, em água. Após períodos de exposição pré-fixados, de $1 \mathrm{~h}, 3 \mathrm{~h}, 5 \mathrm{~h}, 7 \mathrm{~h}$ e a cada $24 \mathrm{~h}$ até $168 \mathrm{~h}$, é determinada a quantidade de água absorvida pela superfície em contato com a água, por diferença de massa. Os ensaios foram realizados à temperatura de $25^{\circ} \mathrm{C}$ e umidade relativa de $50-60 \%$.

O concreto tem a capacidade de absorver água e de secar. O processo de secagem é bastante complexo e depende principalmente do teor inicial de água presente no interior do material, de sua distribuição, do teor crítico de água, do transporte de vapor e das dimensões do próprio elemento de concreto. Essa propriedade normalmente é determinada traçando-se a curva de evaporação de água do material ao longo do tempo (RILEM, 1981).

O método de determinação da evaporação de água teve como diretrizes o ensaio proposto pela BS-6477-92 "Water repellents for masonry surfaces, item 5.4 Evaporation of water". O ensaio normalmente é realizado nos mesmos corpos-de-prova, utilizados 
no ensaio anterior, e consiste na evaporação da água absorvida pelos corpos-de-prova saturados de água. No estudo, com o objetivo de determinar a velocidade de perda de água absorvida no ensaio anterior, os corpos-de-prova contendo água, usados no ensaio anterior, tiveram as faces não pintadas (lateral e face oposta à pintada) impermeabilizadas com selante á base de silicone. A água presente no interior desses corpos-de-prova é evaporada através da face pintada, à temperatura de $25^{\circ} \mathrm{C}$ e umidade relativa de 50-60\%. O fluxo de água que evapora através da pintura aplicada na superfície dos corpos-de-prova é determinado por diferença de massa, ao longo do tempo, durante 15 dias. Este método teve como objetivo simular o mecanismo de perda de água, absorvida por capilaridade pela exposição à chuva, durante 7 dias. Desta forma, o ensaio não foi realizado com corpos-de-prova saturados com água conforme recomendado pela BS-6477.

\section{b) Resistência à penetração do íon cloreto, método acelerado}

A penetração do íon cloreto através dos poros do concreto ocorre em forma de solução, com estes íons dissolvidos em água, como aquela decorrente da maresia. Os cloretos do ambiente penetram no interior do concreto através de mecanismos clássicos de penetração de água e transporte de íons, sendo eles o de absorção capilar, de difusão, de permeabilidade ou de migração de íons, por ação de um campo elétrico ( HELENE, 1993).

Foram desenvolvidos procedimentos de ensaio para a avaliação da resistência à penetração do íon cloreto através dos poros do concreto, sendo o mais difundido o proposto pela Norma ASTM 1202-94 que é um ensaio acelerado, podendo ser realizado em algumas horas. No estudo, foi definido o uso deste procedimento pelo fato das pinturas serem uma barreira de proteção que reduz a velocidade de penetração do 
cloreto, com a vantagem deste método acelerado permitir obter resultados em poucas horas. O procedimento de medida consiste em expor a face pintada dos corpos-de-prova de concreto, de $10 \mathrm{~cm}$ de diâmetro e $5 \mathrm{~cm}$ de espessura, a uma solução de cloreto de sódio e a outra face não pintada a uma solução de hidróxido de sódio. É aplicada uma tensão de $60 \mathrm{~V}$ entre as faces e mede-se a corrente que passa através dos corpos-deprova, a cada 30 minutos, durante 6 horas. A diferença de potencial gera um fluxo de elétrons e, como consequiência, gera uma corrente elétrica. A partir da integração da curva de corrente em função do tempo é calculada a carga elétrica total que passa pelo corpo-de-prova durante esse período. A carga está relacionada com a resistência dos materiais à penetração do íon cloreto, que no estudo são os concretos pintados e sem pintura usados como referência.

Conforme a literatura (ANDRADE, 1993) este método não mede apenas a permeabilidade do concreto ao íon cloreto. O registro da corrente total que passa através da célula é função da quantidade e tipo de íons, e não apenas do fluxo dos íons cloreto. Assim, para corrigir o efeito do método eletrométrico, determinou-se o teor de cloreto presente na solução de cloreto de sódio inicial, antes e após a aplicação da tensão, usando eletrodo de íon seletivo (UEMOTO et al,1995).

\section{c) Profundidade de carbonatação}

A carbonatação é uma das principais formas de deterioração de estruturas de concreto armado no Brasil. Com o objetivo de estudar o efeito da composição das tintas na proteção ao concreto quanto à penetração do $\mathrm{CO}_{2}$, foram expostos em câmara com elevado teor deste agente agressivo, corpos-de-prova, sem e com pintura, com dimensões de $5 \mathrm{~cm} \times 5 \mathrm{~cm} \times 10 \mathrm{~cm}$, extraídos de painéis de concreto. A câmara de carbonatação é de circuito aberto e alimentação contínua por meio de um cilindro de gás 
e ar atmosférico (JOHN, 1995), tendo sido mantida em ambiente à temperatura de 21,5 $\pm 1,5^{\circ} \mathrm{C}$ e umidade no interior da câmara de $80 \%$. Embora muitos ensaios acelerados tenham sido realizados com níveis de concentração mais elevados (PAPADAKIS et al., 1991), a concentração de $\mathrm{CO}_{2}$ no ensaio foi mantida em $5 \%$, de forma a poder ter um maior número de medidas, antes da ocorrência da carbonatação total. A espessura carbonatada do concreto é medida com solução alcoólica de fenolftaleína a 1\%. A faixa de viragem de cor da fenolftaleína é de 8,3 a 10 , sendo vermelho-carmim acima dessa faixa e incolor abaixo dessa faixa, que representa a "frente de carbonatação" (HELENE, 1993). Apesar dos concretos apresentarem agregados graúdos com dimensão característica inferior a $19 \mathrm{~mm}$ a presença destes próxima à superfície de concreto torna a avaliação apenas qualitativa.

\section{d) Exposição ao envelhecimento natural}

O efeito da atmosfera no processo de envelhecimento das tintas e como consequiência a sua influência nos fenômenos de transporte de massa em concretos pintados está sendo estudada através da exposição ao envelhecimento natural. As tintas e o verniz foram aplicados em corpos-de-prova extraídos dos painéis de concreto, de $20 \mathrm{MPa}$ e $40 \mathrm{MPa}$, e expostos na Estação de Envelhecimento Natural (EEN) localizado no IPT - Cidade Universitária - São Paulo- latitude $23^{\circ} 30^{\prime}$ s e longitude $46^{\circ} 37^{\prime} \mathrm{W}$, na posição vertical e inclinada de $30^{\circ}$ em relação à horizontal, ambas voltadas para a face norte.

A posição vertical simula melhor as condições das fachadas dos prédios e a posição inclinada é mais agressiva por estar mais exposta à ação da água de chuva, resultando em maior tempo de permanência da água sobre a superfície, maior facilidade de deposição de partículas do meio ambiente, seja daquelas causadas pela poluição como de esporos de microrganismos biológicos. 
Os resultados obtidos nas duas condições devem ser correlacionados entre si e com os outros resultados de ensaios. Após 12 e 24 meses de exposição devem ser realizadas avaliações de cor e brilho e após os 24 meses de exposição serão realizados os seguintes ensaios:

- exposição na vertical

Os produtos aplicados em painéis de $20 \mathrm{MPa}$ e $40 \mathrm{MPa}$ devem ser avaliados quanto ao aspecto da superfície ( cor, brilho, calcinação, etc.) e profundidade de carbonatação.

- exposição inclinada

Os produtos aplicados nos painéis e nos corpos-de-prova de $10 \times 10 \times 2,5 \mathrm{~cm}$, de $20 \mathrm{MPa}$ e de $40 \mathrm{MPa}$ devem ser avaliados quanto à absorção de água por capilaridade, evaporação de água, carbonatação e avaliação quanto ao aspecto da superfície (cor, brilho, calcinação etc.).

Os corpos-de-prova foram expostos recentemente, em agosto de 1997, sendo assim, a primeira avaliação só será realizada em agosto de 1998. Conforme recomendação de normas estrangeiras, a previsão da durabilidade deve ser realizada com um mínimo de 2 anos de exposição ao envelhecimento natural pois, com um ano de exposição, existe o risco de se obter resultados de exposição em ano atípico. Dentro deste contexto, nesta pesquisa os resultados de durabilidade só serão obtidos após o término da Tese.

Os ensaios de penetração de agentes agressivos foram realizados em concretos recém tratados. Como as pinturas geralmente se degradam ao longo do tempo, os ensaios devem ser repetidos em corpos-de-prova pintados após a exposição ao envelhecimento natural, que melhor simula as condições de uso. 


\section{e) Determinação da porosidade e distribuição de poros das películas de tinta}

A distribuição do tamanho dos poros das tintas influencia o grau de proteção da tinta, afetando o tipo e a velocidade dos mecanismos de transporte. Com o objetivo de correlacionar a microestrutura, de diferentes formulações de tintas, com os fenômenos de transporte de íons agressivos e capacidade de proteção das pinturas, a dimensão e a distribuição dos poros das películas de tinta foram determinadas por duas técnicas diferentes, que permitem obter dados complementares, as quais são:

\section{f) por microscopia eletrônica de varredura (MEV)}

A técnica está sendo utilizada para a determinação do tamanho e distribuição de poros, através de programa analisador de imagens. A análise das tintas foi efetuada no microscópio eletrônico de varredura marca Leica, modelo Stereoscan 440, por imagens de elétrons secundários (SE-1), as que são obtidas pelo espalhamento inelástico dos elétrons incidentes (SHEEHAN, 1995). Foram utilizados três procedimentos para o preparo das amostras de tinta, conforme detalhado a seguir:

- a superfície da película analisada foi obtida por corte de uma seção no micrótomo. A energia de aceleração do feixe de elétrons foi de $20 \mathrm{KV}$;

- a película analisada foi obtida pela aplicação de tinta, com extensor, sobre papel tratado com silicone. A película é descolada do papel e a análise da imagem foi efetuada no lado em contato com este papel. A energia de aceleração do feixe de elétrons foi de $20 \mathrm{KV}$;

- a superfície analisada foi obtida por fratura, tendo sido usadas 2 lâminas de alumínio para a fixação das amostras de tinta, em forma de "Sandwich". Apenas com a tinta de $P V C 0 \%$ a fratura foi realizada após o congelamento da película com nitrogênio 
líquido à temperatura de $-196^{\circ} \mathrm{C}$. A energia de aceleração do feixe de elétrons foi de $5 \mathrm{KV}$; a criopreparação de amostras é uma técnica muito utilizada em estudos biológicos (ALLEMAN et al, 1985); hoje já existem microscópios (crio-MEV) equipados com um estágio de congelamento por nitrogênio líquido para o estudo de microestrutura de formulações de tinta (SHEEHAN, 1995).

\section{g) porosimetria por intrusão de mercúrio}

A técnica consiste na determinação do espectro de dimensões de poros de uma película de tinta, injetando mercúrio sob aumento gradual de pressão na amostra submetida a vácuo e medindo-se o volume do mercúrio absorvido a uma dada pressão o qual é convertido em volume de poro de uma determinada faixa de porosidade. Conforme a norma BS 7591-1992 a faixa ótima de medida é de $0,1 \mu \mathrm{m}$ a $100 \mu \mathrm{m}$; o método se aplica à medição de poros na faixa de $0,003 \mu \mathrm{m}$ a $400 \mu \mathrm{m}$ e mede a porosidade inter e intra partícula, não sendo possível a diferenciação entre um tipo e outro.

\subsection{Relação de ensaios}

Nas Tabela 4. 2 e Tabela 4. 3 está apresentada a relação de ensaios da primeira e da segunda fase, com indicações das propriedades avaliadas, dos métodos de ensaio empregados, das condições das amostras e sua finalidade. 
Tabela 4. 2 : Ensaios da primeira fase: Exploratória

\begin{tabular}{|c|c|c|c|}
\hline \multicolumn{4}{|c|}{ Ensaios na tinta liquida } \\
\hline Propriedades & Método de ensaio & Amostras & Finalidade \\
\hline $\begin{array}{l}\text { Caracterização (sólidos, } \\
\text { veículo e pigmentos) }\end{array}$ & ASTM-D 3723-84 & $\begin{array}{c}\text { Tintas à base de resina } \\
\text { acrílica "pura" e } \\
\text { estireno-acrilica } \\
\end{array}$ & \multirow{2}{*}{$\begin{array}{l}\text { Avaliação comparativa } \\
\text { entre os dois tipos de } \\
\text { tintas e de vernizes, para } \\
\text { seleção da formulação }\end{array}$} \\
\hline $\begin{array}{c}\text { Temperatura mínima } \\
\text { de formação de filme } \\
\text { (TMFF) }\end{array}$ & ASTM-D 2354-91 & $\begin{array}{l}\text { Tintas e polímeros à base } \\
\text { de resina "acrílica pura" e } \\
\text { estireno-acrílica }\end{array}$ & \\
\hline \multicolumn{4}{|c|}{ Ensaios na película } \\
\hline Lavabilidade & ASTM-D 2486-89 & \multirow{6}{*}{$\begin{array}{l}\text { Tintas à base de resina } \\
\text { "acrilica pura" e } \\
\text { estireno-acrilica }\end{array}$} & \multirow{6}{*}{$\begin{array}{l}\text { Avaliação comparativa } \\
\text { entre os dois tipos de } \\
\text { tintas e de vernizes }\end{array}$} \\
\hline $\begin{array}{l}\text { Permeabilidade ao } \\
\text { vapor de água }\end{array}$ & ASTM-D 1653-91a & & \\
\hline $\begin{array}{c}\text { Envelhecimento } \\
\text { acelerado }\end{array}$ & ASTM- G 53-89 & & \\
\hline Brilho & ASTM-D 523-89 & & \\
\hline Cor (Método visual) & ASTM-D 2616-88 & & \\
\hline $\begin{array}{l}\text { Cor (Método } \\
\text { instrumental) }\end{array}$ & ASTM-D 313-73 & & \\
\hline
\end{tabular}

Na Tabela 4.3 está apresentada a relação de ensaios, com indicações das propriedades avaliadas, dos métodos empregados, das condições das amostras e finalidades dos ensaios. 
Tabela 4. 3 : Ensaios da segunda fase: Formulações estudadas

\begin{tabular}{|c|c|c|c|}
\hline \multicolumn{4}{|c|}{ Ensaios no polímero básico } \\
\hline Propriedades & Método de ensaio & Amostras & Finalidade \\
\hline $\begin{array}{l}\text { Identificação da } \\
\text { composição }\end{array}$ & $\begin{array}{l}\text { Espectrofotometria no } \\
\text { infravermelho }\end{array}$ & \multirow{4}{*}{$\begin{array}{l}\text { Resina acrilica e } \\
\text { estireno-acrilica }\end{array}$} & \multirow{4}{*}{$\begin{array}{c}\text { Correlação das } \\
\text { propriedades com } \\
\text { desempenho e durabilidade }\end{array}$} \\
\hline $\begin{array}{c}\text { Massa molecular e } \\
\text { distribuição da massa } \\
\text { molecular }\end{array}$ & $\begin{array}{l}\text { Espectroscopia por } \\
\text { correlaçāo fotônica }\end{array}$ & & \\
\hline $\begin{array}{c}\text { Temperatura de } \\
\text { transição vitrea (Tg) }\end{array}$ & $\begin{array}{c}\text { Calorimetria de varredura } \\
\text { diferencial }\end{array}$ & & \\
\hline $\begin{array}{l}\text { Temperatura mínima de } \\
\text { formação de filme } \\
\text { (TMFF) }\end{array}$ & ASTM-D 2354-91 & & \\
\hline \multicolumn{4}{|c|}{ Ensaios na tinta líquida } \\
\hline $\begin{array}{l}\text { Caracterização (sólidos, } \\
\text { veículo e pigmentos) }\end{array}$ & ASTM-D 3723-84 & \multirow{2}{*}{$\begin{array}{c}\text { Tintas à base de resina } \\
\text { acrílica e } \\
\text { estireno- acrílica }\end{array}$} & \multirow{2}{*}{$\begin{array}{l}\text { Avaliação comparativa } \\
\text { entre os dois tipos de tinta, } \\
\text { para aceitação da } \\
\text { formulação }\end{array}$} \\
\hline $\begin{array}{l}\text { Temperatura mínima de } \\
\text { formação de filme } \\
\text { (TMFF) }\end{array}$ & ASTM-D 2354-91 & & \\
\hline \multicolumn{4}{|c|}{ Ensaios na película } \\
\hline Lavabilidade & ASTM- D 2486-89 & \multirow{6}{*}{$\begin{array}{l}\text { Tintas à base de resina } \\
\text { acrílica e estireno-acrilica }\end{array}$} & \multirow{6}{*}{$\begin{array}{l}\text { Avaliação comparativa } \\
\text { entre os dois tipos de tinta }\end{array}$} \\
\hline $\begin{array}{l}\text { Permeabilidade ao vapor } \\
\text { de água }\end{array}$ & ASTM-D 1653-91a & & \\
\hline $\begin{array}{l}\text { Envelhecimento } \\
\text { acelerado }\end{array}$ & ASTM- G 53-89 & & \\
\hline Brilho & ASTM- D 523-89 & & \\
\hline Cor (Método visual) & ASTM-D 2616-88 & & \\
\hline $\begin{array}{l}\text { Cor (Método } \\
\text { instrumental) }\end{array}$ & ASTM-D 313-73 & & \\
\hline $\begin{array}{c}\text { Tamanho e distribuiçāo } \\
\text { dos poros }\end{array}$ & $\begin{array}{c}\text { Porosimetria por intrusão } \\
\text { de mercúrio }\end{array}$ & \multirow{2}{*}{$\begin{array}{l}\text { Tintas à base de resina } \\
\text { acrílica pura }\end{array}$} & \multirow{2}{*}{$\begin{array}{l}\text { Correlação da } \\
\text { microestrutura com } \\
\text { transporte de massa }\end{array}$} \\
\hline Morfologia & $\begin{array}{l}\text { Microscopia eletrônica de } \\
\text { varredura }\end{array}$ & & \\
\hline \multicolumn{4}{|c|}{ Ensaios no sistema concreto/pintura } \\
\hline $\begin{array}{l}\text { Absorção de água por } \\
\text { capilaridade }\end{array}$ & BS-6477-92 (item 5.3) & \multirow{5}{*}{$\begin{array}{c}\text { Tintas à base de resina } \\
\text { acrílica pura }\end{array}$} & \multirow{4}{*}{$\begin{array}{l}\text { Influência das tintas na } \\
\text { proteção dos concretos }\end{array}$} \\
\hline Evaporação de água & BS-6477-92 (item 5.4) & & \\
\hline $\begin{array}{c}\text { Penetração de ion } \\
\text { cloreto }\end{array}$ & ASTM C 1202-94 & & \\
\hline $\begin{array}{l}\text { Profundidade de } \\
\text { carbonatação }\end{array}$ & $\begin{array}{l}\text { Exposição em câmara de } \\
\qquad \mathrm{CO}_{2}\end{array}$ & & \\
\hline Envelhecimento natural & ASTM G 7-89 & & Durabilidade das tintas \\
\hline
\end{tabular}




\section{RESULTADOS EXPERIMENTAIS}

\subsection{Preparação dos substratos de concreto}

Os resultados dos ensaios de caracterização dos materiais e os métodos usados para a dosagem e moldagem dos substratos estão apresentados no ANEXO B.

\subsection{Estudo exploratório (Primeira fase)}

\subsubsection{Caracterização das resinas}

\section{a) Identificação da composição}

Os espectrogramas obtidos do resíduo de evaporação a $105^{\circ} \mathrm{C}$, sobre cristal de $\mathrm{KBr}$, estão apresentados nas Figura 5. 1 e Figura 5. 2, sendo o primeiro da amostra analisada e os restantes os respectivos espectros de referência. A análise feita por comparação em banco de espectros mostrou com $81 \%$ de probabilidade de certeza que, a resina adquirida no mercado como sendo estireno-acrílico, é basicamente um copolímero de poli(acrilato) com estireno, enquanto que, a resina adquirida como sendo "acrílico puro" é basicamente um poli(ester acrilato) com estireno ${ }^{19}$, com $75 \%$ de probabilidade de certeza.

\footnotetext{
${ }^{19}$ Existe um conceito no mercado de se denominar resina "acrílica pura" àquela copolimerizada com teor de estireno inferior a $50 \%$.
} 


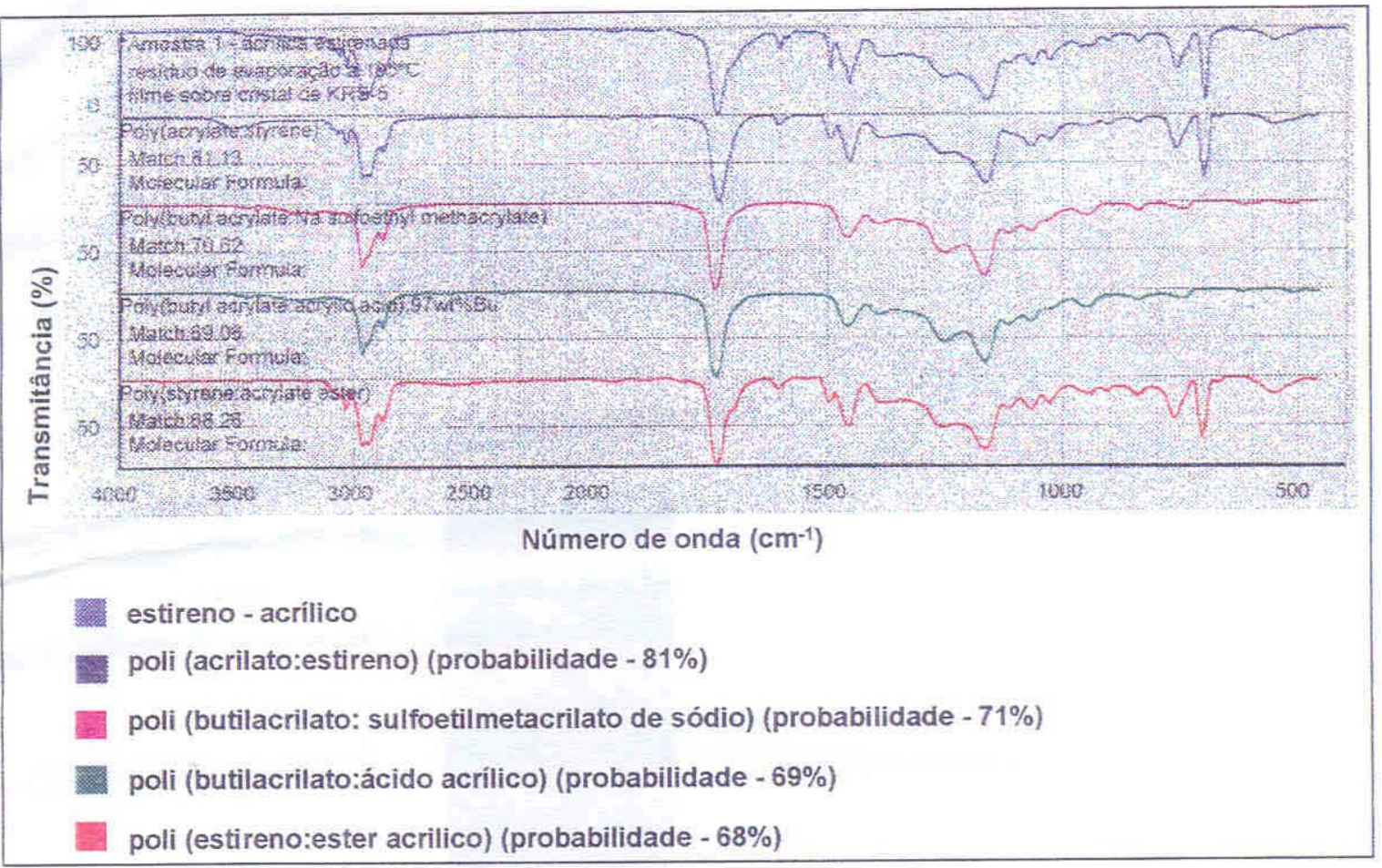

Figura 5.1 : Espectro de infravermelho do polímero estireno-acrílico da fase exploratória.

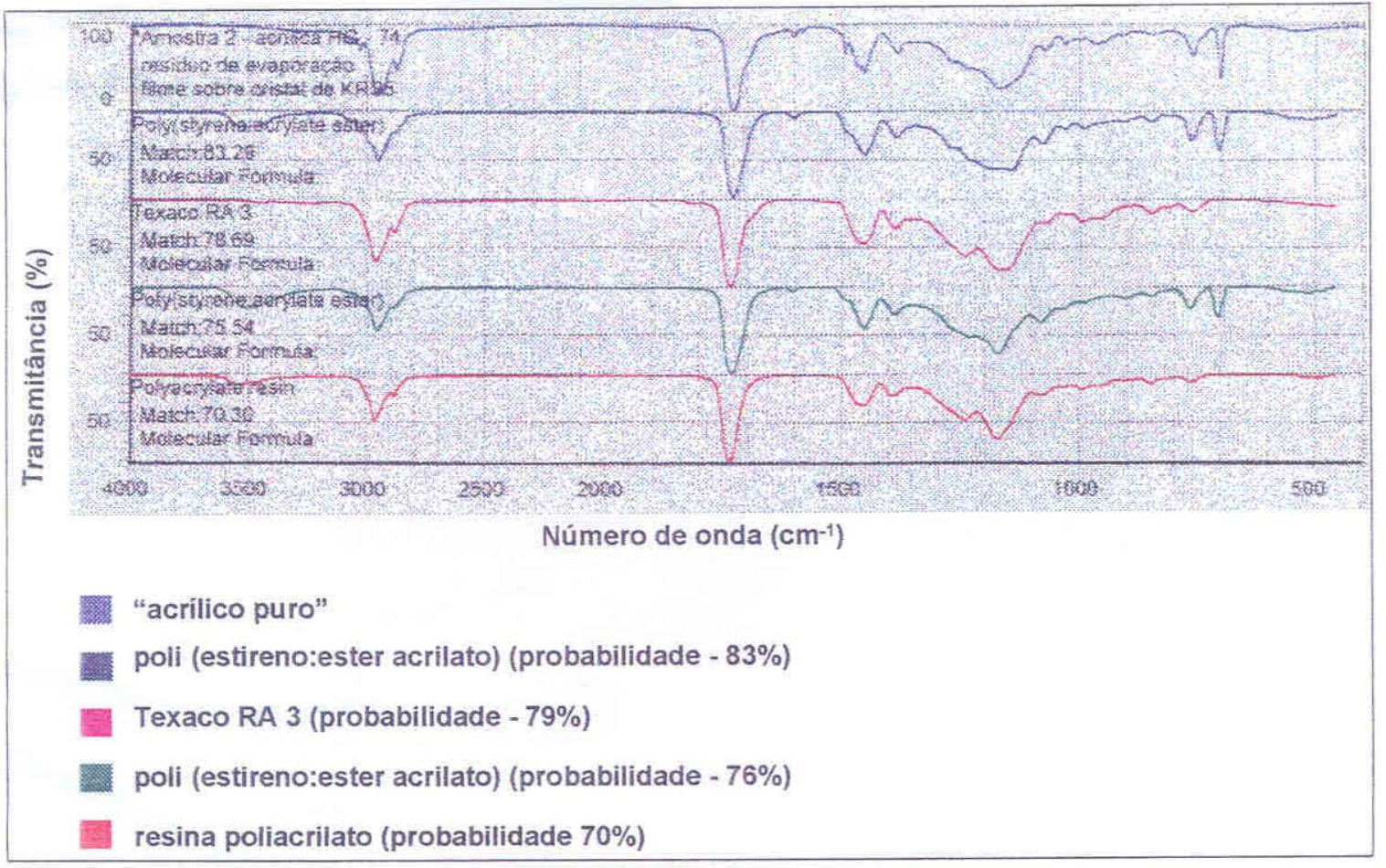

Figura 5. 2 : Espectro de infravermelho do polímero "acrílico puro" da fase 


\section{b) Tamanho médio e distribuição da massa molecular}

Nas Figura 5. 3 e Figura 5. 4 estão ilustradas as intensidades de distribuição. A resina estireno-acrílico possui dimensão média de partículas de $112 \pm 2 \mathrm{~nm}$ e polidispersidade igual a $0,12 \pm 0,03$, enquanto que a resina acrílica "pura" possui dimensão média de partículas de $94 \pm 0,7 \mathrm{~nm}$ e polidispersidade igual a $0,05 \pm 0,02$. Os resultados obtidos mostram que a dimensão média de partículas da resina estireno/acrílica é superior ao acrílico puro e também maior dispersidade ${ }^{20}$.

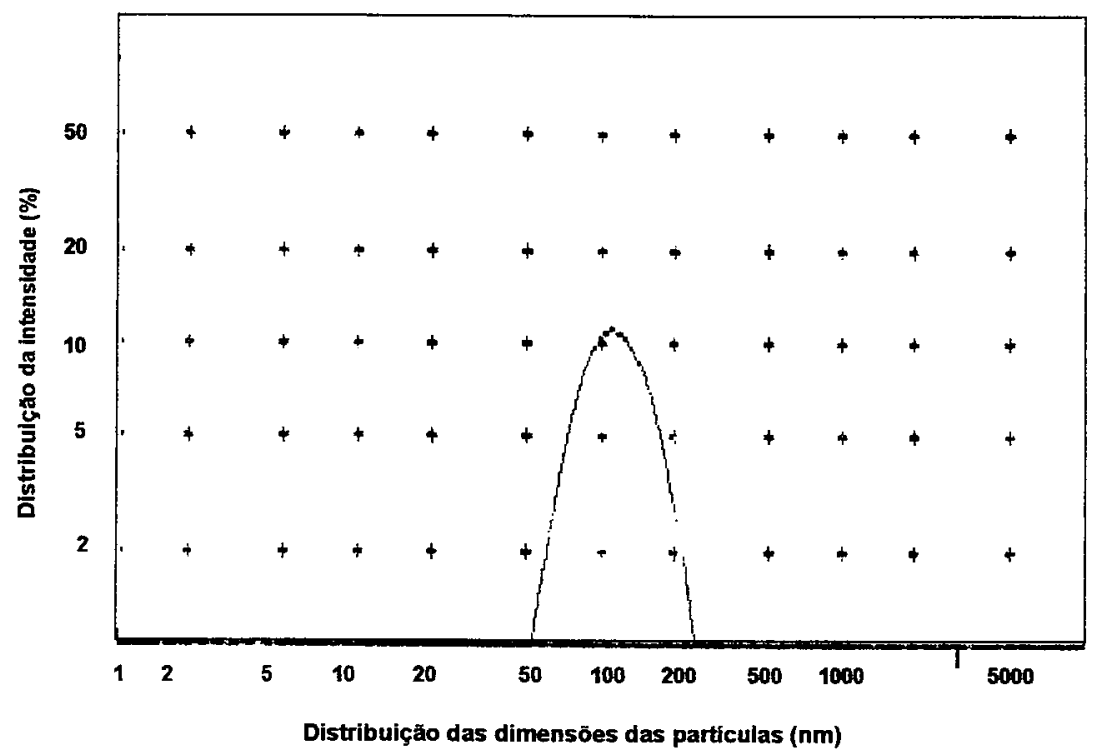

Figura 5. 3 : Curva de distribuição da massa molecular do polímero estirenoacrílico da fase exploratória.

\footnotetext{
${ }^{20}$ Maior heterogeneidade nas massas moleculares.
} 


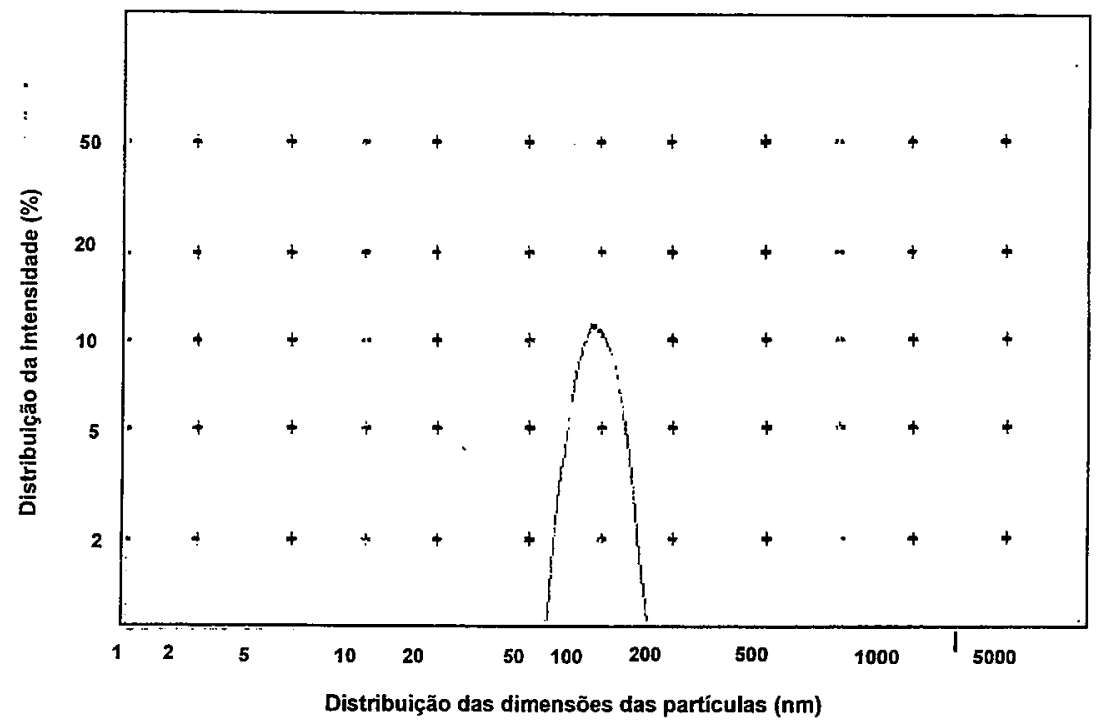

Figura 5. 4 : Curva de distribuição da massa molecular do polímero "acrílico puro" da fase exploratória.

\section{c) Temperatura de transição vítrea (Tg)}

O polímero foi aplicado em uma placa de vidro e seco a $100^{\circ} \mathrm{C}$ e a determinação realizada na faixa de temperatura de $-20^{\circ} \mathrm{C}$ a $70^{\circ} \mathrm{C}$. As curvas de $\mathrm{Tg}$ obtidas estão apresentadas nas Figuras 5.5 e Figura 5.6, mostrando para o estireno-acrílico valor de $19,6^{\circ} \mathrm{C}$ e para o "acrílico puro" de $28,1^{\circ} \mathrm{C}$. A Tg do "acrílico puro" é bem superior ao do estireno-acrílico, indicando que esta resina apresenta módulo de elasticidade bem superior à outra resina. 


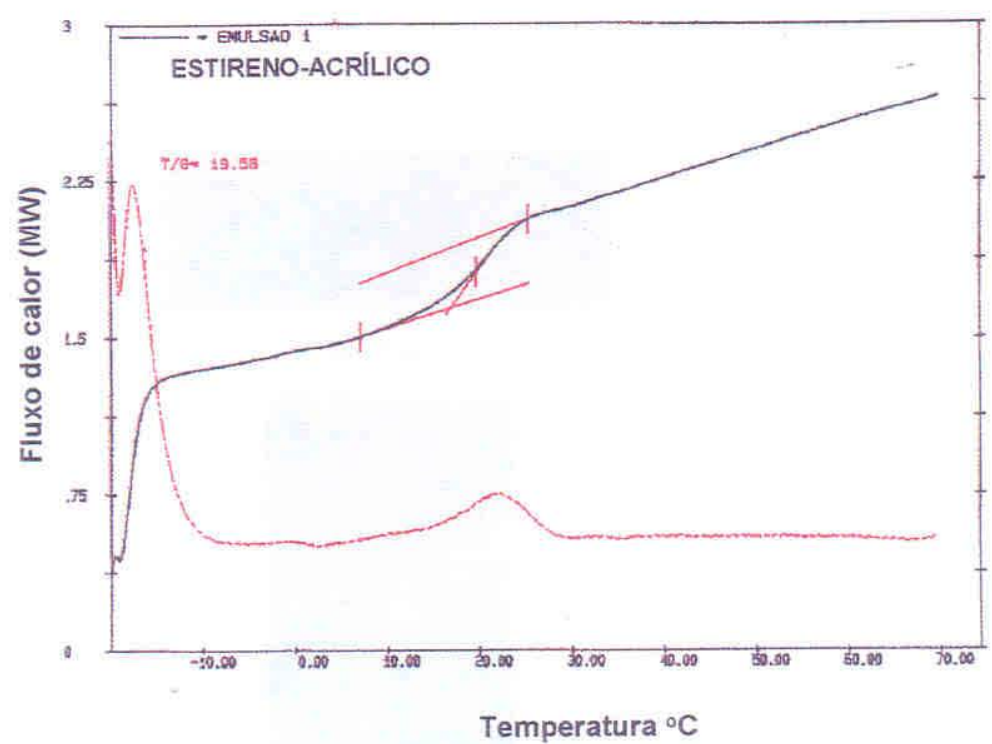

Figura 5. 5 : Curva de temperatura de transição vítrea do polímero estirenoacrílico da fase exploratória.

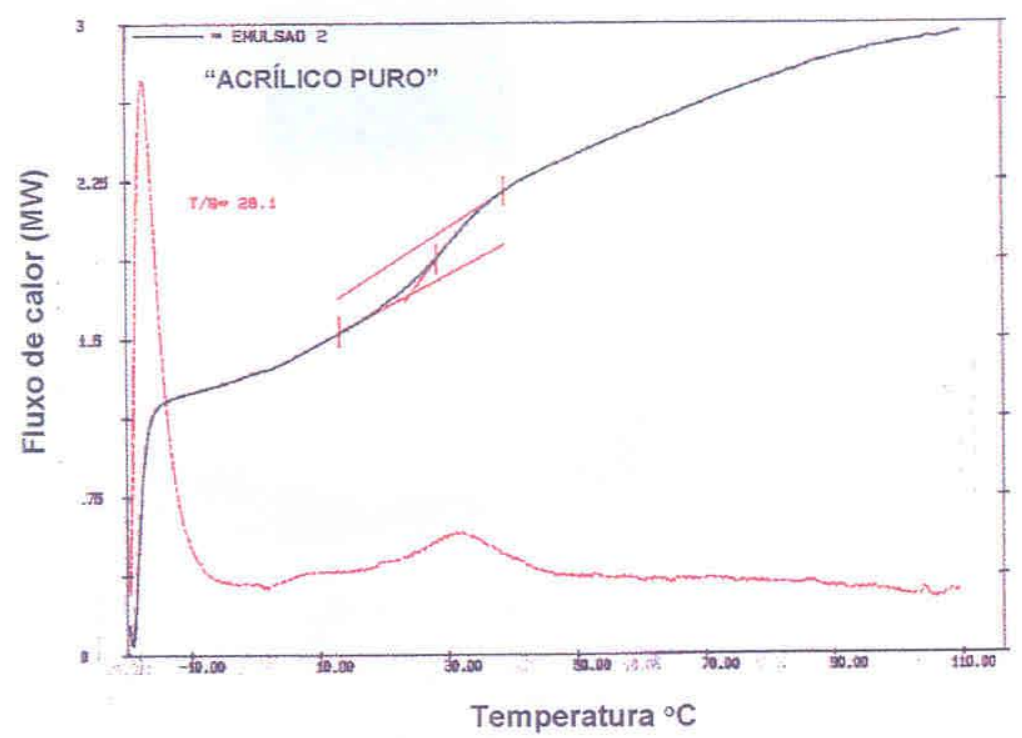

Figura 5. 6 : Curva de temperatura de transição vítrea do polímero "acrílico puro" da fase exploratória.

d) Temperatura mínima de formação de filme (TMFF)

$\mathrm{O}$ ensaio foi realizado na escala de temperatura de calor/frio de $50^{\circ} \mathrm{C}$ a $23^{\circ} \mathrm{C}$. Os resultados obtidos para a resina "acrílica pura" e o estireno-acrílico estão apresentados na Tabela 5. 4. 


\subsubsection{Composição das tintas}

As amostras foram preparadas no laboratório de pesquisa de um fabricante de tinta e, conforme declarado, possuem a composição química básica apresentada nas Tabela 5.1 e Tabela 5.2.

Tabela 5.1 : Composição química bấsica das tintas

\begin{tabular}{|c|c|c|c|c|c|c|c|}
\hline \multirow{2}{*}{$\begin{array}{l}\text { Tipo de resina } \\
(\text { PVC, em } \%)\end{array}$} & \multicolumn{2}{|c|}{ "Acrilico puro" } & \multicolumn{5}{|c|}{ Estireno-acrilico } \\
\hline & 30 & 50 & 50 & 30 & 20 & 10 & Zero \\
\hline \multicolumn{8}{|c|}{ Componentes $(\%)$} \\
\hline Emulsão $^{21 \text { (a) }}$ & 40,3 & 28,9 & 27,9 & 39,0 & 46,3 & 54,0 & 62,2 \\
\hline Dióxido de titânio & 21,5 & 10,2 & 10,6 & 21,5 & 14,7 & 7,6 & - \\
\hline Mica & 4,48 & 6,0 & 6,0 & 4,48 & 3,08 & 1,6 & - \\
\hline Agalmatolito & - & 3,51 & 3,5 & - & - & - & - \\
\hline Caulim & - & 11,4 & 11,4 & - & - & - & - \\
\hline Carbonato de cálcio & - & 2,7 & 2,7 & - & - & - & - \\
\hline Água & 33,7 & 36,9 & 37,9 & 35,1 & 35,9 & 36,8 & 37,8 \\
\hline Pigmento (carga) ${ }^{(b)}$ & 26,0 & 34,2 & 34,2 & 26,0 & 17,8 & 9,2 & - \\
\hline $\operatorname{Resina}^{(b)}$ & 17,1 & 12,3 & 12,3 & 17,1 & 20,4 & 23,8 & 27,4 \\
\hline
\end{tabular}

Observação: (a) Teor de sólidos da emulsão: "Acrílico puro": 42,5 \% e Estireno-acrilico: 44,0 \%;

(b) Valores obtidos por cálculo

Tabela 5. 2 : Outros componentes adicionados às tintas

\begin{tabular}{|c|c|c|c|c|c|}
\hline Tpoderesina & \multicolumn{2}{|c|}{ 64colice puro } & \multicolumn{2}{|c|}{ Whineno-morico } & Whang \\
\hline PVC\% & 50 & 30 & 50 & 30 & $7 \times x$ \\
\hline (1) & $\sqrt{x}$ & dentes & 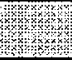 & & 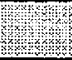 \\
\hline Butil glicol & - & - & 0,60 & 0,91 & - \\
\hline Propileno glicol & 1,77 & 2,56 & - & - & - \\
\hline Dowanol PPH & - & - & 0,60 & 0,90 & - \\
\hline Dowanol DPNB & 1,65 & 2,36 & - & - & - \\
\hline Dowanol DPN & - & - & - & - & 0,52 \\
\hline Aguarrás & - & - & 0,60 & 0,90 & - \\
\hline óleo de pinho & - & - & 0,20 & 0,20 & - \\
\hline
\end{tabular}

\footnotetext{
${ }^{21}$ Dispersão aquosa de polímero acrílico.
} 


\subsubsection{Caracterização e lavabilidade das tintas}

Os resultados de caracterização e da resistência à lavabilidade estão apresentados na Tabela 5. 3.

Tabela 5. 3 : Resultados de ensaios de caraterização e de desempenho

\begin{tabular}{|c|c|c|c|c|c|}
\hline \multirow{2}{*}{ Determinações } & \multicolumn{5}{|c|}{ Amostras } \\
\cline { 2 - 6 } & \multicolumn{2}{|c|}{ “Acrílico puro" } & \multicolumn{3}{|c|}{ Estireno-acrílico } \\
\cline { 2 - 6 } & PVC 50\% & PVC 30\% & PVC 50\% & PVC 30\% & PVC 0\% \\
\hline Teor de sólidos (\%) & 49,6 & 47,8 & 49,4 & 46,6 & 30,3 \\
\hline Teor de resinas (\%) & 17,9 & 21,7 & 18,0 & 20,9 & 30,2 \\
\hline Teor de pigmentos (\%) & 31,8 & 22,1 & 31,4 & 25,7 & 0,28 \\
\hline $\begin{array}{c}\text { Resistência à } \\
\text { lavabilidade (ciclos) }\end{array}$ & 335 & 180 & 311 & 276 & - \\
\hline
\end{tabular}

Os resultados mostram que as tintas possuem composição química bastante semelhante aos produtos encontrados no mercado, inclusive comercializados como de primeira linha. A única exceção observada foram os resultados de lavabilidade onde foram encontrados valores normalmente apresentados para acabamentos semi-brilho ( $P V C$ $30 \%$ ) no lugar de acabamentos fosco (PVC 50\%). De modo geral, quanto maior o teor de resina maior é a resistência à lavabilidade; no entanto, os resultados mostram para PVC 50\% há maior resistência à lavabilidade do que para $P V C 30 \%(17,1 \%)$, apesar de ter sido formulado com menor teor de resina $(12,3 \%)$. Os resultados obtidos também serviram para a aceitação destas tintas e continuação do estudo.

\subsubsection{Temperatura minima de formação de filme (TMFF)}

$\mathrm{O}$ ensaio foi realizado em 2 condições de escala de temperatura de calor/frio $\left(18^{\circ} \mathrm{C}\right.$ a $4^{\circ} \mathrm{C}$ e $13^{\circ} \mathrm{C} \mathrm{a}-5^{\circ} \mathrm{C}$ ). Os resultados obtidos para as tintas e os polímeros "acrílico puro" e estireno-acrílico estão apresentados na Tabela 5. 4. 
Tabela 5. 4 : Resultados de temperatura mínima de formação de filme (TMFF)

\begin{tabular}{|c|c|c|c|c|}
\hline \multirow{2}{*}{$\begin{array}{c}\text { Tipo } \\
\text { de tinta e/ou resina }\end{array}$} & \multirow{2}{*}{$\begin{array}{l}\text { PVC } \\
(\%)\end{array}$} & \multicolumn{3}{|c|}{ Temperatura mínima de formação de filme $\left({ }^{\circ} \mathrm{C}\right)$} \\
\hline & & $18^{\circ} \mathrm{C}$ a $4^{\circ} \mathrm{C}$ & $13^{\circ} \mathrm{C}$ a $-5^{\circ} \mathrm{C}$ & $50^{\circ} \mathrm{C}$ a $23^{\circ} \mathrm{C}$ \\
\hline \multirow{3}{*}{ Tinta estireno/acrílica } & 50 & - & 0 & - \\
\hline & 30 & - & 0 & - \\
\hline & $\mathbf{0}$ & 15 & $>13$ & - \\
\hline \multirow[b]{2}{*}{ Tinta "acrílica pura" } & 50 & Nãò formou filme & $-2,5$ & - \\
\hline & 30 & Não formou filme & $-2,5$ & - \\
\hline Resina "acrílica pura" & - & - & - & 26 \\
\hline Resina estireno/acrilica & - & - & - & $<23$ \\
\hline
\end{tabular}

Os resultados obtidos mostraram que os dois tipos de tinta não apresentam os mesmos valores de TMFF; a tinta "acrílica pura" apresenta TMFF inferior a $0^{\circ} \mathrm{C}\left(-2,5^{\circ} \mathrm{C}\right)$ enquanto que a estireno-acrílica apresenta valor usual de mercado que é de $0^{\circ} \mathrm{C}$. Ambas apresentam TMFF adequada para uso em qualquer região do país. As duas resinas, acrílica pura e estireno-acrílica, apresentaram valores de $26^{\circ} \mathrm{C}$ e de $<23^{\circ} \mathrm{C}$, respectivamente e que são considerados valores usuais de mercado.

\subsubsection{Permeabilidade ao vapor de água}

Foi determinada à temperatura de $23^{\circ} \mathrm{C}$, em duas condições de umidade relativa (UR = $30 \%$ e 50\%). Os resultados obtidos estão apresentados na Tabela 5.5 . 
Tabela 5.5 : Resultados de permeabilidade ao vapor de água

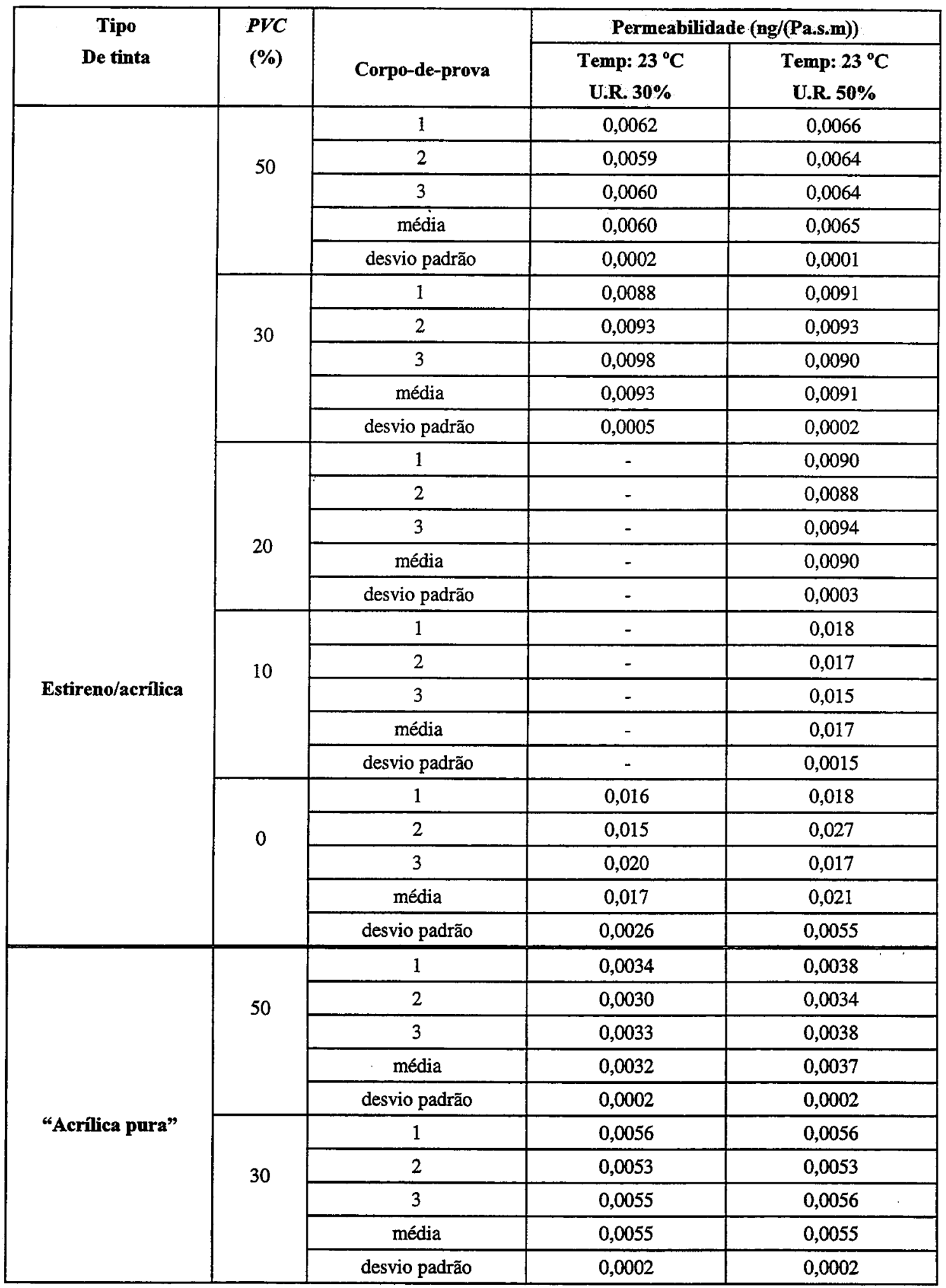


Comparando-se as médias obtidas nos dois níveis de umidade relativa de ensaio, verifica-se através da análise de variância (ANOVA) que, a um nível de significância de $5 \%$, não existe diferença entre as permeabilidades medidas com umidade relativa de $30 \%$ ou $50 \%$. Este comportamento foi observado nos dois tipos de tinta com diferentes PVCs. A única exceção observada foi na película obtida com tinta estireno-acrílica de PVC 50\%. Sendo assim, na continuação da pesquisa, os ensaios foram realizados em apenas uma única condição de umidade relativa.

Os resultados mostram que as tintas de mesmo PVC, à base de resina "acrílica pura", formam películas de menor permeabilidade ao vapor de água do que aquelas à base de estireno-acrílica, apesar de terem sido produzidas com o mesmo teor de resina e de pigmentos, com exceção dos valores de produtos coalescentes citados na Tabela 5.2. Através da mesma análise verifica-se que, a um nível de significância de 5\%, a permeabilidade ao vapor de água da tinta "acrílica pura" é significativamente diferente da tinta estireno-acrílica, tanto com PVC 30\% como com PVC 50\%.

Os resultados obtidos mostram para ambos os tipos de resina, as tintas com PVC 30\%, que contem em sua composição maior teor de veículo não volátil, de $21 \%$, apresenta maior permeabilidade ao vapor de água do que a de PVC 50\%, que possui menor teor de veículo não volátil, de $18 \%$. Para o verniz, PVC 0\%, a permeabilidade é maior ainda, confirmando de certa forma os valores obtidos para as tintas.

A análise dos resultados obtidos com as tintas à base de estireno-acrílica mostram que quanto maior o teor de resina e menor o PVC maior a permeabilidade ao vapor de água, com exceção das tintas de PVC $20 \%$ e $+30 \%$ que apresentaram valores de permeabilidade muito próximos. 


\subsubsection{Envelhecimento acelerado}

Após a exposição as películas obtidas com a resina "acrílica pura" tornaram-se quebradiças, sendo o mesmo fenômeno observado com o estireno-acrílico, mas com menor intensidade. A Figura 5.7 mostra o aspecto das películas obtidas com resina "acrílica pura" e com estireno-acrílico, após 300 h de envelhecimento acelerado. A Figura 5. 8 mostra o aspecto das películas obtidas com estireno-acrílico, após 600 h de envelhecimento acelerado.

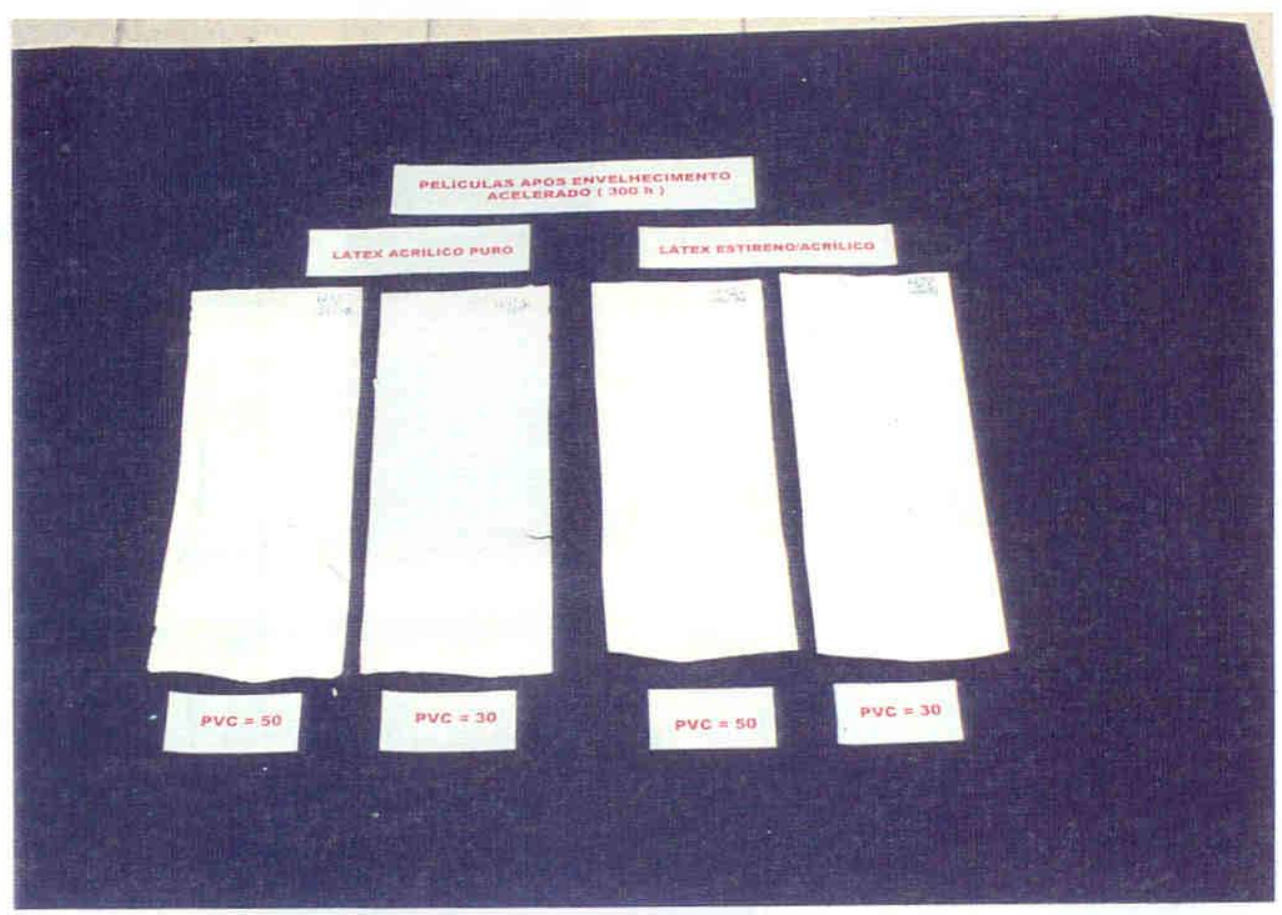

Figura 5. 7 : Aspecto das películas, obtidas com resina "acrílica pura" e com estireno-acrílico, após $300 \mathrm{~h}$ de envelhecimento acelerado. 


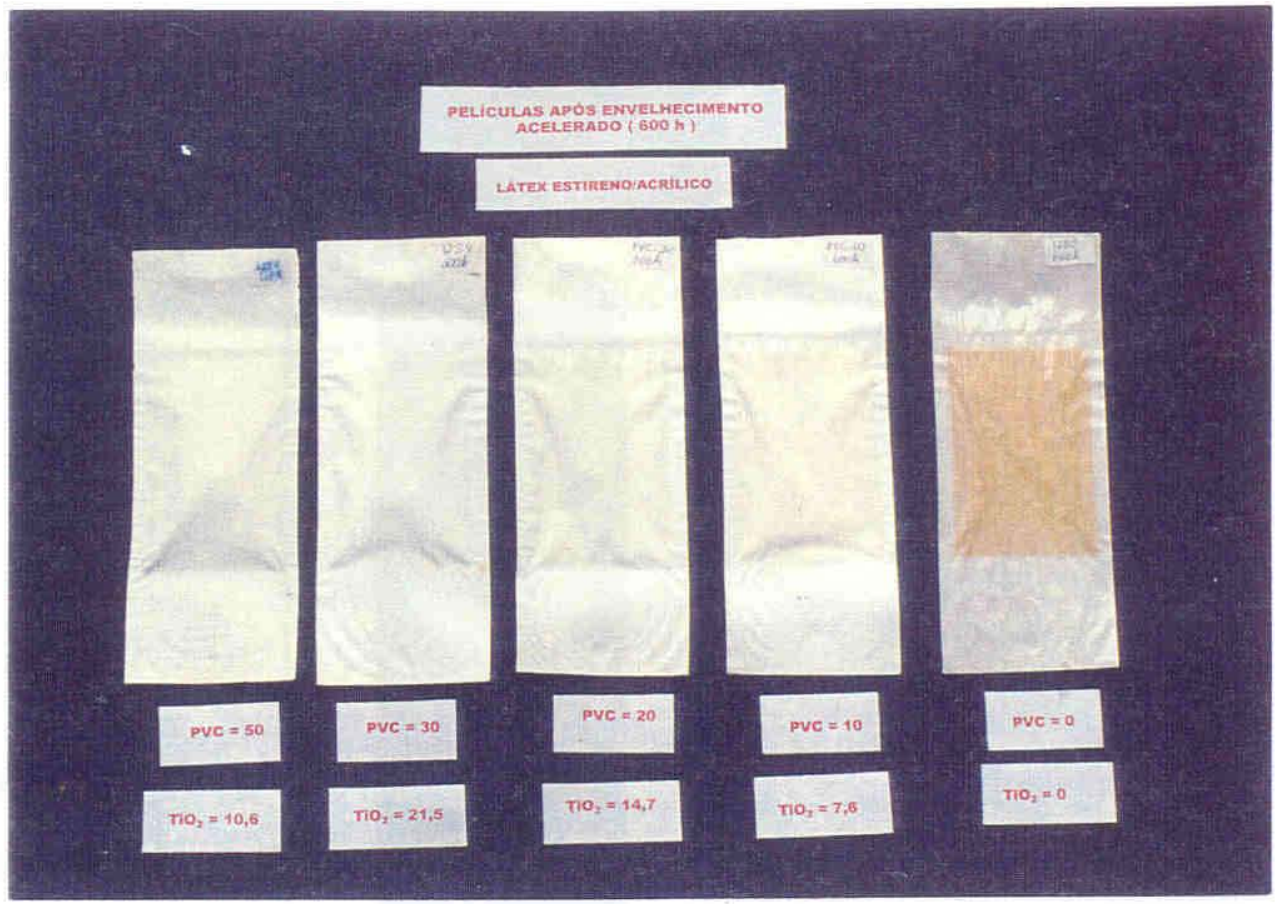

Figura 5. 8 : Aspecto das películas obtidas com resina estireno-acrílico, após $600 \mathrm{~h}$ de envelhecimento acelerado.

Observa-se que quanto menor o valor de PVC e menor o teor de pigmento maior é a alteração de cor e de índice de amarelecimento. $\mathrm{O}$ verniz que não contêm adição de pigmentos apresentou elevado índice de amarelecimento. O ensaio mostrou que as duas tintas, formuladas com os dois tipos de resinas e com os mesmos teores e composição de pigmentos, apresentaram baixa resistência a esta condição de exposição, entretanto, não foram observados os mesmos tipos de alteração.

\section{a) Avaliação da alteração do brilho}

Os resultados médios obtidos, de 6 determinações, e os respectivos desvios-padrão encontram-se apresentados na Tabela 5.6 e os resultados individuais apresentados na Tabela A.I, no ANEXO A. 
Tabela 5. 6 : Determinação do brilho, sem e após envelhecimento acelerado

\begin{tabular}{|c|c|c|c|c|c|c|c|}
\hline \multirow[b]{3}{*}{ Timas. } & \multirow{3}{*}{$\begin{array}{l}P Q C \\
(\%)\end{array}$} & \multirow{2}{*}{\multicolumn{2}{|c|}{ emelhecimento }} & \multicolumn{4}{|c|}{ após envelhecimento } \\
\hline & & & & \multicolumn{2}{|c|}{$=: 300 h$} & \multicolumn{2}{|c|}{$600 \%$} \\
\hline & & media & $\begin{array}{l}\text { desvio } \\
\text { padrão }\end{array}$ & media & $\begin{array}{l}\text { destio } \\
\text { padráo. }\end{array}$ & meghe & $\begin{array}{l}\text { desvio } \\
\text { padrio }\end{array}$ \\
\hline \multirow{5}{*}{ Estireno-acrílico } & 50 & 2,60 & 0,00 & 1,98 & 0,30 & 2,23 & 0,14 \\
\hline & 30 & 26,6 & 0,80 & 6,77 & 1,16 & 4,13 & 0,86 \\
\hline & 20 & 37,8 & 2,13 & 9,47 & 1,84 & 7,47 & 1,42 \\
\hline & 10 & 47,4 & 3,79 & 12,8 & 1,98 & 5,07 & 0,62 \\
\hline & 0 & 71,0 & 4,12 & 11,0 & 3,02 & 4,40 & 1,19 \\
\hline \multirow[t]{2}{*}{ "Acrilica pura" } & 50 & 2,78 & 0,26 & 2,27 & 0,40 & 2,32 & 0,39 \\
\hline & 30 & 23,6 & 1,49 & 7,78 & 2,12 & 9,55 & 1,84 \\
\hline
\end{tabular}

Os resultados obtidos mostram que nos dois tipos de tintas, de PVC 50\% e acabamento fosco, não apresentaram alterações significativas no brilho, enquanto que, as tintas de PVC inferiores, de acabamento semi-brilho, perderam o brilho; observou-se que quanto maior o brilho e o periodo de exposição (600 horas) mais intensa a alteração.

\section{b) Avaliação da alteração da cor com base na escala cinza}

Os resultados médios obtidos, da avaliação feita em 3 diferentes corpos-de-prova, estão apresentados na Tabela 5.7. 
Tabela 5.7 : Avaliação visual após envelhecimento acelerado

\begin{tabular}{|c|c|c|c|c|c|}
\hline \multirow[t]{2}{*}{ Tintas } & \multirow{2}{*}{$\begin{array}{l}\text { PVC } \\
(\%)\end{array}$} & \multicolumn{2}{|c|}{$\begin{array}{c}\text { Avaliação colorimétrica } \\
\text { visual, com base na escala } \\
\text { cinza }\end{array}$} & \multicolumn{2}{|c|}{ Alterações observadas } \\
\hline & & $300 \mathrm{~h}$ & $600 \mathrm{~h}$ & $300 \mathrm{~h}$ & $600 \mathrm{~h}$ \\
\hline \multirow{5}{*}{$\begin{array}{l}\text { Estireno- } \\
\text { acrilico }\end{array}$} & 50 & 4 & 4 & as; $\mathrm{fm}$ & as; $\mathrm{fm}$ \\
\hline & 30 & 4 & 4 & as; fm; bi & as; $\mathrm{fm}$; bi \\
\hline & 20 & 4 & $4 / 5$ & as; fm; bi & as; $\mathrm{fm}$; bi \\
\hline & 10 & $3 / 4$ & 4 & $\mathrm{am} ; \mathrm{fm} ; \mathrm{bi}$ & $\mathrm{am} ; \mathrm{fm} ; \mathrm{bi}$ \\
\hline & $\mathbf{0}$ & $2 / 3$ & 2 & ai; fi; bi & ai; fi; bi \\
\hline \multirow[t]{2}{*}{ "Acrílica pura" } & 50 & $<4 / 5$ & $<4 / 5$ & as; $\mathrm{fi}$ & as; fi \\
\hline & 30 & 5 & 5 & as; fi; bs & as; fi ; bm \\
\hline
\end{tabular}

\section{Legenda:}

Classificação:

$5=$ sem alteração de cor

$4=$ suave alteração de cor

3 = notável alteração de cor

2 = elevada alteração de cor

$1=$ muito elevada alteração de cor $\mathrm{a}=$ amarelecimento

$\mathrm{b}=$ perda de brilho

$\mathrm{f}=$ perda de flexibilidade

$s=$ suave

$\mathrm{m}=$ moderado

$\mathrm{i}=$ intenso

A avaliação qualitativa realizada mostrou que as tintas formuladas com os dois tipos de resinas, com os mesmos teores e composição de pigmentos, apresentaram baixa resistência a ciclos alternados de radiação ultravioleta e à condensação. Após a exposição, as tintas à base de resina "acrílica pura" perderam a flexibilidade e tornaramse quebradiças; o mesmo fenômeno é observado com tintas à base de estireno/ acrílico, mas com menor intensidade. Estas apresentaram maior alteração de cor e de brilho e quanto maior o teor de veículo maior é a alteração observada. O verniz, que é constituído praticamente só de veículo, foi aquele que apresentou maior alteração de cor. 
c) Avaliação da alteração de cor por método instrumental computadorizado

Os resultados médios, obtidos de 6 determinações, e os respectivos desvios-padrão encontram-se apresentados na Tabela 5.8 e os resultados individuais apresentados na Tabela A.II, do ANEXO A.

Tabela 5. 8 : Avaliação colorimétrica instrumental computadorizada

\begin{tabular}{|c|c|c|c|c|c|c|c|c|c|}
\hline \multirow{3}{*}{ Tintas } & \multirow{3}{*}{$\begin{array}{l}\text { PVC } \\
(\%)\end{array}$} & \multicolumn{4}{|c|}{$300 \mathrm{~h}$} & \multicolumn{4}{|c|}{$600 \mathrm{~h}$} \\
\hline & & \multicolumn{2}{|c|}{$\begin{array}{c}\text { Alteração de } \\
\text { cor }\end{array}$} & \multicolumn{2}{|c|}{$\begin{array}{l}\text { Indice de } \\
\text { amarelecimento }\end{array}$} & \multicolumn{2}{|c|}{$\begin{array}{c}\text { Alteração de } \\
\text { cor }\end{array}$} & \multicolumn{2}{|c|}{$\begin{array}{l}\text { Indice de } \\
\text { amarelecimento }\end{array}$} \\
\hline & & média & $\begin{array}{l}\text { desvio } \\
\text { padrão }\end{array}$ & $\begin{array}{c}\text { Médi } \\
\text { a }\end{array}$ & $\begin{array}{l}\text { desvio } \\
\text { padrāo }\end{array}$ & média & $\begin{array}{l}\text { desvio } \\
\text { padrão }\end{array}$ & média & $\begin{array}{l}\text { desvio } \\
\text { padrão }\end{array}$ \\
\hline \multirow{5}{*}{$\begin{array}{l}\text { Estireno } \\
\text {-acrílico }\end{array}$} & 50 & 1,44 & 0,026 & 2,06 & 0,049 & 1,29 & 0,022 & 1,80 & 0,058 \\
\hline & 30 & 1,49 & 0,018 & 2,21 & 0,028 & 1,44 & 0,018 & 2,09 & 0,046 \\
\hline & 20 & 2,50 & 0,145 & 3,68 & 0,200 & 2,26 & 0,096 & 3,33 & 0,149 \\
\hline & 10 & 4,20 & 0,383 & 6,18 & 0,558 & 3,93 & 0,125 & 5,79 & 0,187 \\
\hline & 0 & 15,1 & 0,099 & 22,5 & 0,161 & 19,2 & 0.307 & 28,1 & 28,1 \\
\hline \multirow{2}{*}{$\begin{array}{l}\text { "Acrílica } \\
\text { pura" }\end{array}$} & 50 & 0,62 & 0,026 & 0,52 & 0,148 & 0,67 & 0,043 & 0,48 & 0,014 \\
\hline & 30 & 0,68 & 0,046 & 1,01 & 0,022 & 0,76 & 0,021 & 0,90 & 0,038 \\
\hline
\end{tabular}

O método instrumental computadorizado permite correlacionar o teor de dióxido de titânio nas alterações de cor e amarelecimento.

Os dados de alteração de cor observadas nas tintas à base de resina estireno-acrílica, indicados na Tabela 5. 1, foram correlacionados com os teores de dióxido de titânio referidos na Tabela 5.2, presentes nas tintas de PVC 30\%, 20\% e 10\%, e no verniz, sem esta adição. A influência do dióxido de titânio na alteração de cor é mostrada nas Figura 5. 9 e Figura 5. 10. 

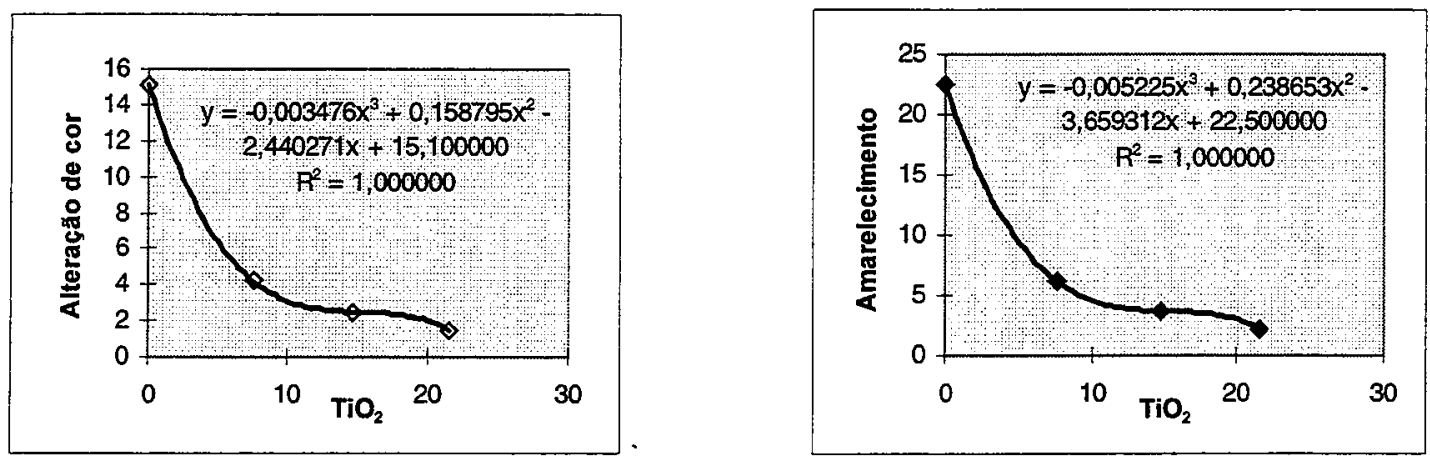

Figura 5.9 : Influência do $\mathrm{TiO}_{2}$ na exposição ao envelhecimento acelerado (300 h)
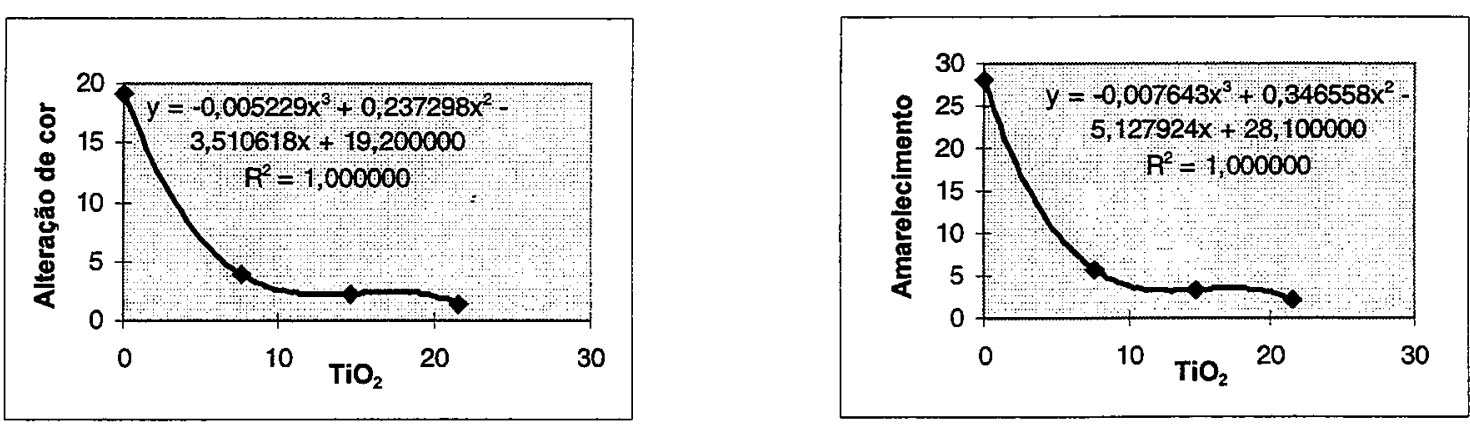

Figura 5. 10 : Influência do $\mathrm{TiO}_{2}$ na exposição ao envelhecimento acelerado (600 h)

Nestes gráficos estão apresentados os valores medidos e a curva ajustada aos mesmos através do método de mínimos quadrados. Os coeficientes de correlação obtidos mostram que a equação do $3^{\circ}$ grau explica a variação do comportamento de alteração de cor e do índice de amarelecimento em relação ao teor de titânio.

Estas curvas mostram que o efeito do titânio é mais significativo para baixos teores de adição e que, a partir de certo nível, a sua influência diminui significativamente no desempenho das películas quanto à influência da radiação UV, nos ensaios de envelhecimento natural ou acelerado. Os resultados obtidos confirmam os dados da literatura (BALFOUR \& HUCHETTE, 1995) conforme discutido anteriormente nas considerações sobre a formulação. 
Portanto, os resultados mostram que quanto menor o valor de PVC e de dióxido de titânio maior é a alteração da cor e do indice de amarelecimento. O verniz que não contem adição de pigmentos apresentou elevado índice de amarelecimento e quanto maior o tempo de exposição mais intenso é o índice.

\subsubsection{Comentários sobre o estudo exploratório (Primeira fase)}

De acordo com os resultados e comentários anteriormente apresentados as tintas "acrílicas pura" após a cura e envelhecimento acelerado resultaram em filmes quebradiços. Polímeros de temperatura de transição vítrea ( $\mathrm{Tg}$ ) elevada de $28,1^{\circ} \mathrm{C}$, conforme determinada no item 5.2.1, resultam em filmes rígidos e quebradiços. As tintas mostraram características inadequadas para aplicações onde havia necessidade de propriedades elásticas para melhor acomodação dos efeitos de contração e expansão do concreto.

O estudo exploratório mostrou que havia a necessidade de redirecionar a pesquisa, preparando novas amostras, com polímeros de $\mathrm{Tg}$ inferior ao estudado, objetivando a obtenção de tintas com menor módulo de elasticidade. Também foram redefinidas as relações de PVC, pois a série estudada era composta por somente uma tinta de acabamento fosco e o restante por acabamento semi-brilho, não sendo muito representativas do mercado.

\subsection{Formulação estudada (Segunda Fase)}

Foram realizados alguns ensaios de caracterização dos polímeros básicos usados na preparação das tintas; da mesma forma que no estudo exploratório foi realizada a avaliação comparativa entre os dois tipos de tinta; análise da microestrutura das tintas à base de resina acrílica pura e ensaios para verificar o efeito das tintas acrílicas na 
penetração de íons cloreto, água e vapor de água e $\mathrm{CO}_{2}$ em concretos de baixa e de elevada resistência mecânica.

\subsubsection{Caracterização das resinas}

\section{a) Identificação da composição}

Os espectrogramas obtidos do resíduo de evaporação a $105^{\circ} \mathrm{C}$, sobre cristal de $\mathrm{KBr}$, estão apresentados nas Figura 5. 11 e Figura 5. 12, sendo o primeiro a amostra padrão e os demais os respectivos espectros de referência usados para a pesquisa. A análise feita por comparação em banco de espectros, confirmou com probabilidade de certeza de $68 \%$, que a resina declarada pelo fabricante como sendo estireno-acrílico, é basicamente um copolímero de polietilacrilato com estireno e, que a resina declarada como sendo acrílico puro, com probabilidade de certeza de $84 \%$, é basicamente um poli(metilmetacrilato:butilacrilato). Pode-se concluir que ambas as resinas apresentam a composição declarada pelo fabricante.

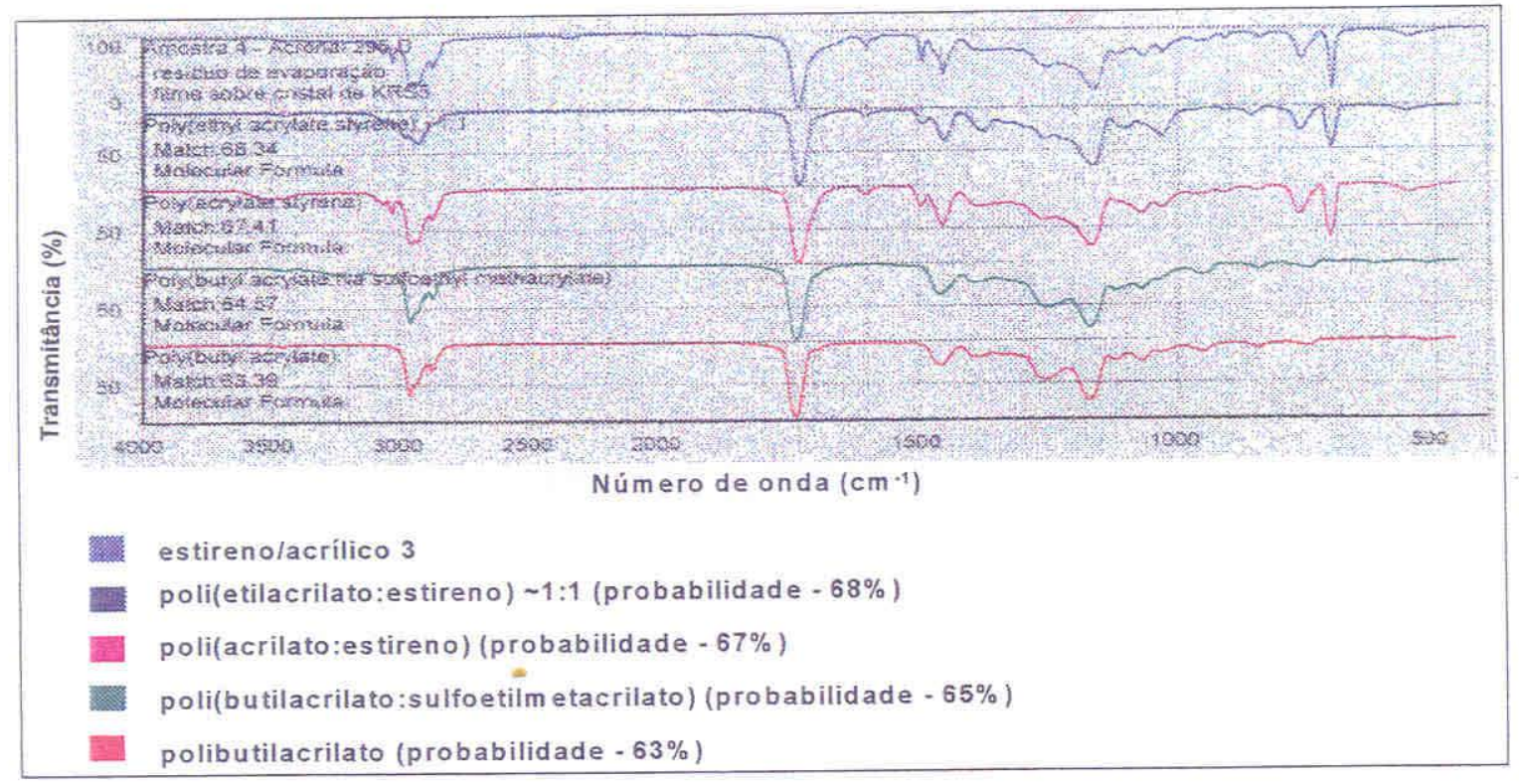

Figura 5. 11 : Espectro de infravermelho do polímero estireno-acrílico da segunda fase. 


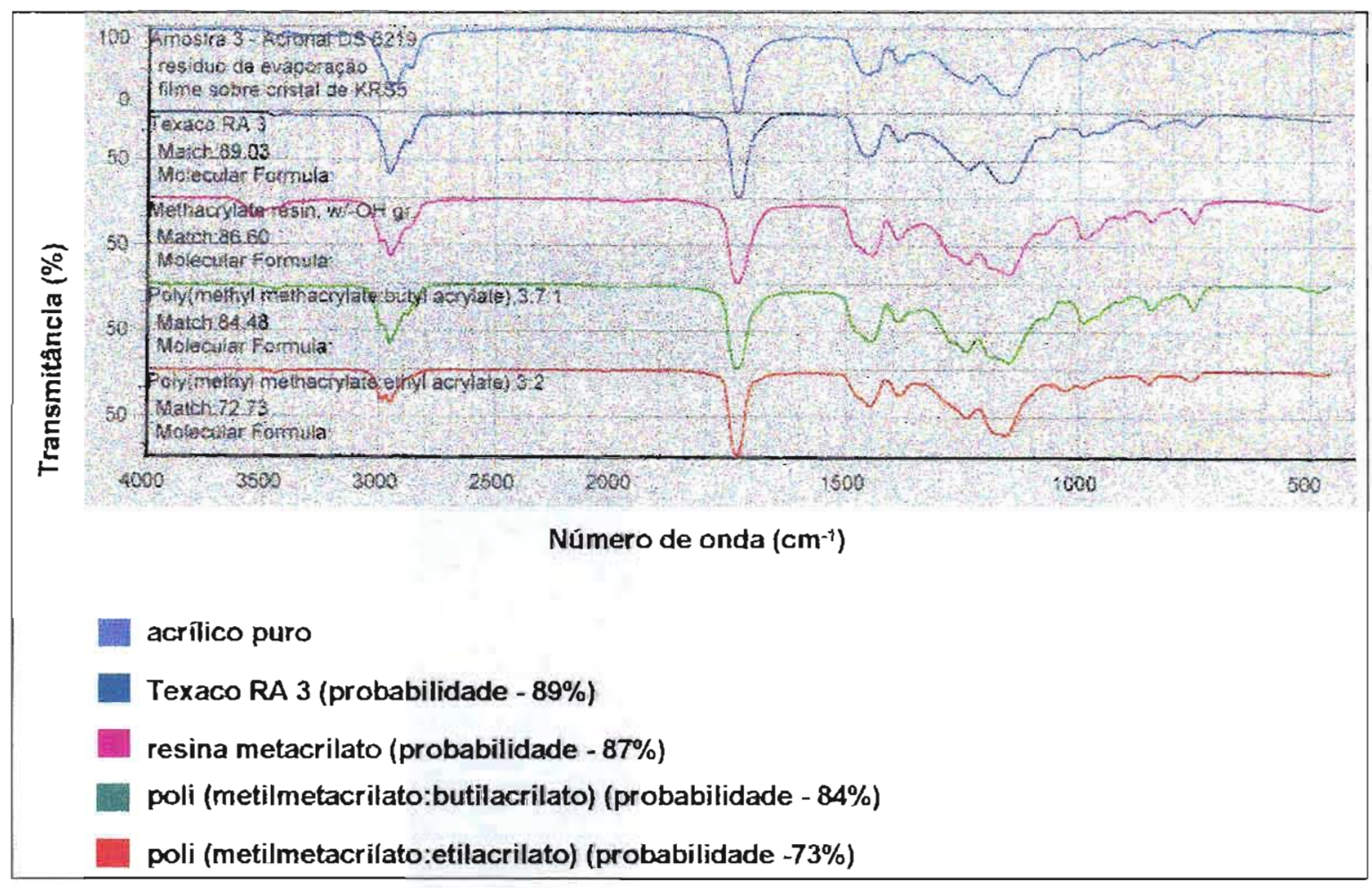

Figura 5. 12 : Espectro de infravermelho do polímero acrílico puro da segunda fase.

\section{b) Tamanho médio e distribuição da massa molecular}

Nas Figura 5. 13 e Figura 5. 14 estão ilustradas as intensidades de distribuição. A resina acrílica pura possui dimensão média de partículas de $204 \pm 0,9 \mathrm{~nm}$ e polidispersidade de igual a $0,03 \pm 0,01$, enquanto que a resina estireno-acrílico possui dimensão média de partículas de $142 \pm 1 \mathrm{~nm}$ e polidispersidade igual a $0,06 \pm 0,02$. Os resultados obtidos mostram que a dimensão média de partículas da resina estireno/acrílica é inferior ao acrílico puro e maior dispersidade, isto é maior heterogeneidade nas massa moleculares. 


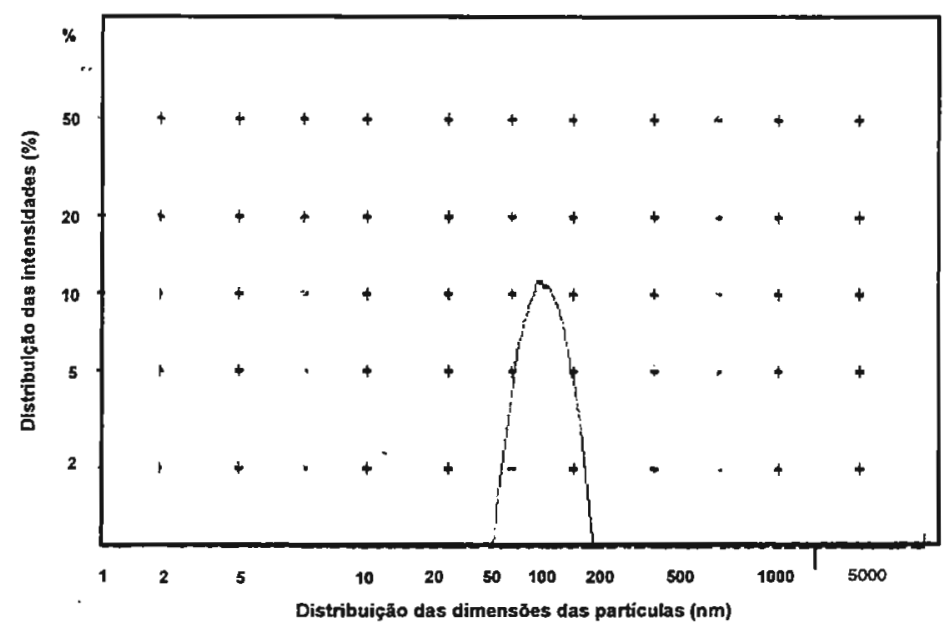

Figura 5. 13 : Curva de distribuição da massa molecular do polímero estirenoacrílico da segunda fase.

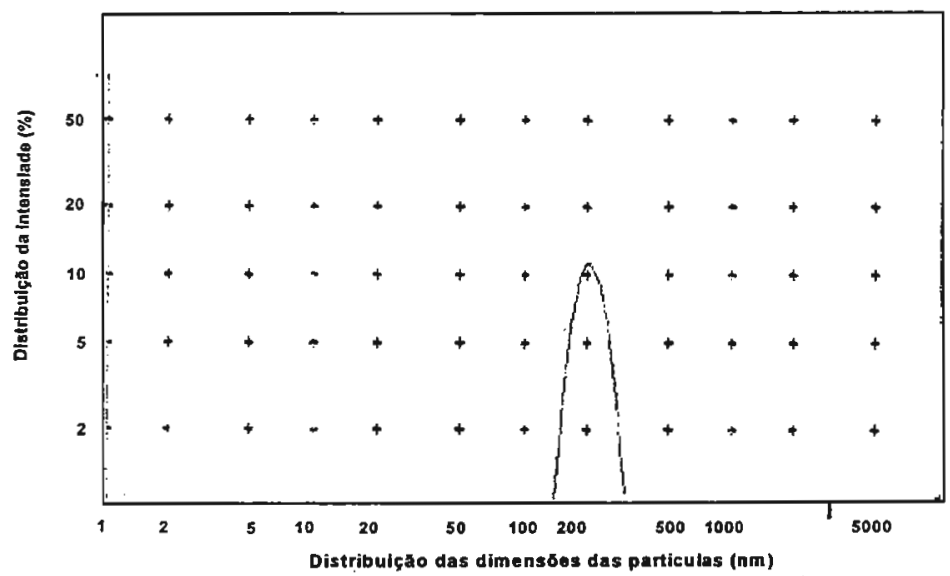

Figura 5. 14 : Curva de distribuição da massa molecular do polímero acrílico puro da segunda fase.

\section{c) Temperatura de transição vítrea $(\mathrm{Tg})$}

As curvas de Tg obtidas estão apresentadas nas Figura 5. 15 e Figura 5. 16, mostrando para o estireno-acrílico valor de $23,6^{\circ} \mathrm{C}$ e para o "acrílico puro" de $21,4^{\circ} \mathrm{C}$. A Tg do "acrílico puro" é próximo ao do estireno-acrílico, indicando que ambas as resinas 
apresentam módulo de elasticidade semelhantes e, além disso, inferior ao da resina "acrílica pura" da fase exploratória.

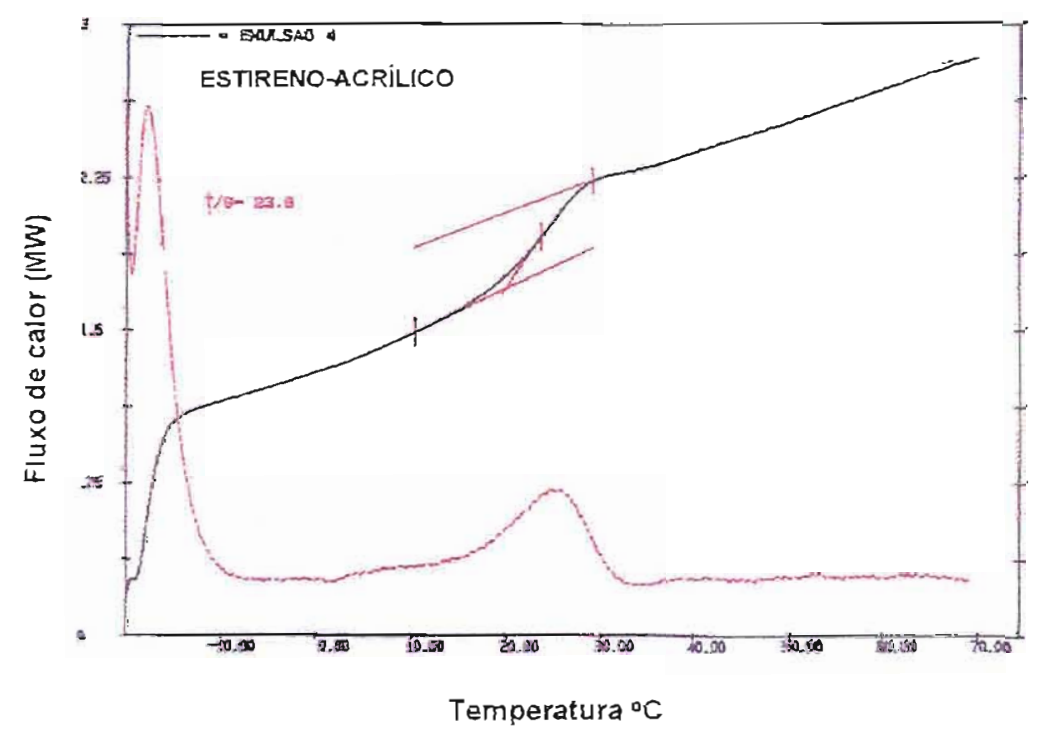

Figura 5, 15: Curva de temperatura de transição vítrea do polímero estirenoacrílico da segunda fase.

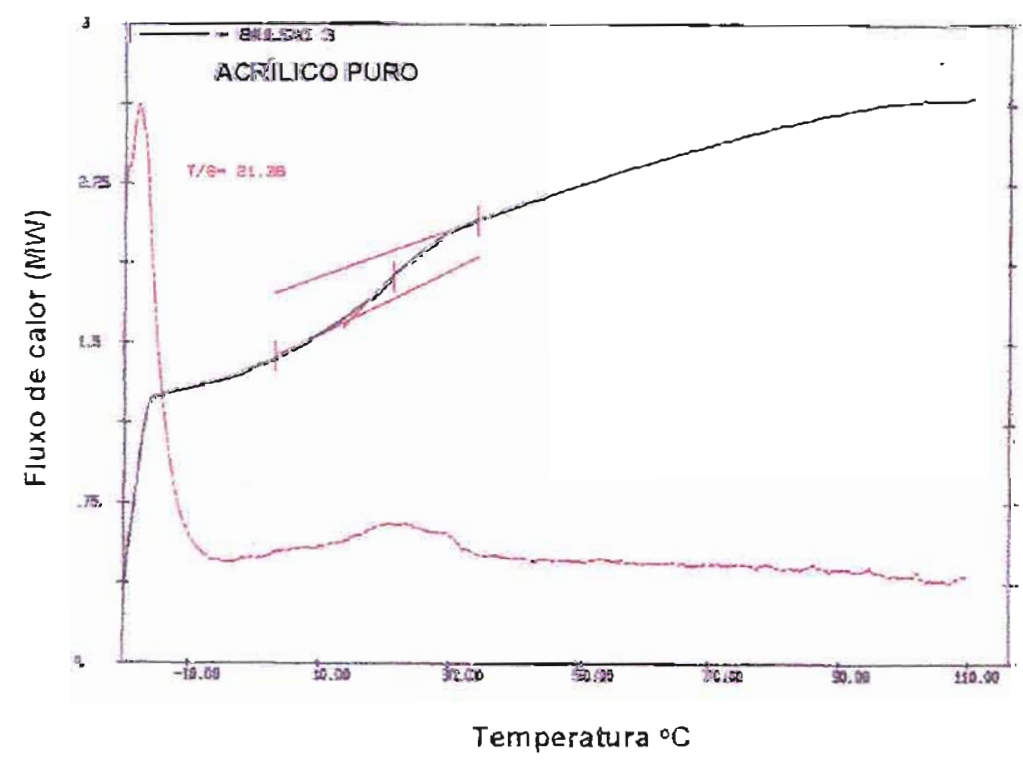

Figura 5. 16 : Curva de temperatura de transição vítrea do polímero acrílico puro da segunda fase. 


\section{d) Temperatura mínima de formação de filme (TMFF)}

Os resultados mostraram que as duas resinas apresentam temperaturas mínimas de formação de filme de $22^{\circ} \mathrm{C}$. Conforme apresentada na literatura (HOY, 1996) existe uma relação entre a TMFF e a $\mathrm{Tg}$, nos polímeros e os homopolímeros, conforme a equação a seguir:

$\operatorname{TMFF}\left(\mathrm{K}^{\circ}\right) / \mathrm{Tg}\left(\mathrm{K}^{\circ}\right)=0,935$

Portanto, o valor da $\mathrm{Tg}$ esta próximo ao valor de TMFF. Os resultados obtidos mostraram que a resina acrílica pura apresentava valor de TMFF um pouco acima do valor da $\mathrm{Tg}$ declarado pelo fabricante, durante os contatos realizados inicialmente. Conforme informação do fabricante, a faixa de variação aceita normalmente está entre $18^{\circ} \mathrm{C}$ a $22^{\circ} \mathrm{C}$; a obtida é de $22^{\circ} \mathrm{C}$, assim, as amostras foram aceitas para o preparo das tintas da segunda fase conforme programado, no entanto, com polímero de $\mathrm{Tg}$ pouco acima do valor previsto.

\subsubsection{Preparação de novas amostras de tintas}

As amostras de tinta foram preparadas usando as fórmulas-sugestão do fabricante, para tintas à base de resina estireno/acrílica, as quais foram preparadas junto com as outras amostras à base de acrílico puro para a realização de avaliação de desempenho comparativo prévio. Toda a matéria prima usada no preparo das amostras foi fornecida por este fabricante e as tintas produzidas em seu laboratório de pesquisa. As tintas e o verniz à base de resina acrílica pura e estireno-acrílica foram preparadas com os materiais listados na Tabela 5.9. 
Tabela 5. 9 : Materiais usados no preparo das formulações de tintas

\begin{tabular}{|c|c|c|c|c|c|}
\hline \multirow[b]{2}{*}{ Componentes } & \multicolumn{5}{|c|}{ Quantidades em massa (g) de componentes $/ 1000$ (g) de tinta } \\
\hline & $\begin{array}{l}P V C \\
75 \%\end{array}$ & $P V C 60 \%$ & PVC $40 \%$ & $P V C 25 \%$ & PVC 0\% \\
\hline \multicolumn{6}{|c|}{$11^{2}$ parte } \\
\hline Água & 200,00 & 215,00 & 128,00 & 40,00 & - \\
\hline Cellosize QP 100m & 2,00 & - & - & - & - \\
\hline Cellosize 15000 & & 2,00 & 51,00 & 100,00 & - \\
\hline Amoníaco & 0,50 & 0,50 & 1,75 & 3,00 & - \\
\hline Nitrito de Sódio & 0,04 & 0,05 & 0,05 & 0,05 & - \\
\hline Antarol TS 709 & 0,50 & 1,50 & 1,00 & 0,50 & - \\
\hline Polysal MD 20 & 6,00 & 6,00 & 6,00 & 6,00 & - \\
\hline Renex 100 & 2,00 & 2,00 & 2,00 & 2,00 & - \\
\hline \multicolumn{6}{|c|}{$2^{\mathrm{a}}$ parte } \\
\hline Caulim Micronizado & 60,00 & - & 17,50 & 35,00 & - \\
\hline $\begin{array}{c}\text { Carbonato de Cálcio } \\
\text { ptdo }\end{array}$ & 105,00 & 70,00 & 40,00 & 10,00 & - \\
\hline $\begin{array}{c}\text { Dióxido de Titânio } \\
\text { (Rutilo) }\end{array}$ & 80,00 & 150,00 & 178,00 & 205,00 & - \\
\hline Talco & 30,00 & 45,00 & 22,50 & - & - \\
\hline Calcita (\#325) & 120,00 & - & - & - & - \\
\hline Calcita (\#400) & - & 130,00 & 65,00 & - & - \\
\hline Silica Diatomácia & 14,50 & 15,00 & 7,50 & - & - \\
\hline Água para lavagem & 48,50 & 40,00 & 45,00 & 50,00 & - \\
\hline \multicolumn{6}{|c|}{$3^{\text {a }}$ parte } \\
\hline Água & 11,00 & 15,00 & 12,5 & 10,00 & 150,00 \\
\hline Amoníaco (25 \%) & 1,00 & - & - & - & 4,65 \\
\hline Degresal ES 002 & - & - & - & - & 0,25 \\
\hline Óleo de pinho & - & - & - & - & 0,25 \\
\hline Querosene & 12,80 & 15,00 & 15,00 & 15,00 & - \\
\hline Butildiglicol & 4,00 & 8,00 & 11,50 & 15,00 & - \\
\hline Antarol TS 709 & 1,65 & 0,44 & 0,97 & 1,50 & - \\
\hline Resina Acronal ${ }^{(1)}$ & 90,00 & 180,00 & 290,00 & 400,00 & 850,00 \\
\hline \multicolumn{6}{|c|}{4 parte } \\
\hline Água & 70,00 & 80,00 & 70,00 & 60,00 & - \\
\hline Latekoll BX 2284 & 15,00 & 15,00 & 17,5 & 20,00 & - \\
\hline Amoníaco (25\%) & 3,50 & 3,50 & 3,40 & 3,30 & $=$ \\
\hline \multicolumn{6}{|c|}{ S. parte } \\
\hline Água & 100,00 & - & - & - & - \\
\hline Cellosize QP 100M & 1,50 & - & - & - & - \\
\hline Amoníaco (25\%) & 0,50 & - & - & - & - \\
\hline \multicolumn{6}{|c|}{6 parte } \\
\hline Água & 14,00 & - & 6,32 & 12,64 & - \\
\hline Matizante & 0,01 & 0,01 & 0,01 & 0,01 & - \\
\hline Busan 1024 & 5,00 & 5,00 & 5,00 & 5,00 & - \\
\hline \multicolumn{6}{|l|}{ Busan 1030} \\
\hline
\end{tabular}

Observação: (1) Teor de sólidos da emulsão:

Acrilico puro: 50,0 \% (DS 6219 - alemã)

Estireno-acrilico: 50,5 \% (295 D - nacional) 


\section{Procedimento de preparo das tintas}

Os materiais relacionados na $1^{\mathrm{a}}$ parte são pesados e misturados até a formação de gel e submetidos à agitação à 1200 rpm durante 5 minutos. Posteriormente são adicionados lentamente os materiais (as cargas) da $2^{a}$ parte usando a mesma agitação durante 30 minutos. As outras partes são misturadas separadamente sob agitação à $600 \mathrm{rpm}$ e adicionadas à $2^{\mathrm{a}}$ parte.

Todas as tintas foram preparadas com este procedimento com exceção do verniz que foi elaborado misturando-se todos os componentes em uma única vez, sob agitação.

\subsubsection{Caracterização e lavabilidade}

Conforme definido, as tintas devem estar bem proporcionadas e apresentar características semelhantes aos produtos disponíveis no mercado. Da mesma forma que no estudo exploratório foram realizados alguns ensaios prévios para a aceitação das mesmas. As amostras obtidas com os dois tipos de polímero foram caracterizadas quanto aos teores de sólidos, de resina (perda de massa a $450^{\circ} \mathrm{C}$ ) e de pigmentos (ASTM D-3723). Também foi determinada a resistência à lavabilidade, que fornece indicações quanto às propriedades de formação da película (ASTM D- 2486-89). Este ensaio não é significativo para o verniz. Os valores médios obtidos de duas determinações estão apresentados na Tabela 5.10 a seguir:

Tabela 5. 10 : Resultados de ensaios de caraterização e desempenho

\begin{tabular}{|c|c|c|c|c|c|c|c|c|c|c|}
\hline \multirow{3}{*}{ Beterminacoes } & \multicolumn{10}{|c|}{ Amostmas } \\
\hline & \multicolumn{5}{|c|}{ IStireno-acentico } & \multicolumn{5}{|c|}{ scrileo puro } \\
\hline & $75 \%$ & $60 \%$ & $40 \%$ & $25 \%$ & $0 \%$ & $75 \%$ & $60 \%$ & $40 \%$ & $25 \%$ & $0 \%$ \\
\hline Sólidos (\%) & 46,1 & 51,5 & 48,5 & 45,2 & 42,5 & 47,1 & 51,6 & 49,0 & 45,0 & 42,3 \\
\hline Resinas (\%) & 7,02 & 10,6 & 16,3 & 23,0 & 42,2 & 7,10 & 10,8 & 16,8 & 21,6 & 42,1 \\
\hline Pigmentos (\%) & 39,1 & 41,0 & 32,2 & $22 ; 2$ & 0,30 & 40,0 & 40,8 & 32,2 & 23,4 & 0,21 \\
\hline Lavabilidade (ciclos) & 50 & 313 & 600 & 604 & - & 31 & 432 & 725 & 1086 & - \\
\hline
\end{tabular}


Os resultados obtidos mostraram que os produtos apresentavam características normalmente encontradas no mercado e além disso, ambos os tipos de tinta apresentaram resultados de lavabilidade comparativos e dentro do esperado pelo fabricante do polímero.

\subsubsection{Temperatura mínima de formação de filme (TMFF)}

Os dois tipos de tintas foram aplicados sobre um substrato com gradiente de temperatura controlada e foi determinada a temperatura de formação de filme. O ensaio foi realizado, conforme diretrizes da norma ASTM D 2354-91, em equipamento de marca Coesfeld Thermostair, na faixa de temperatura de $-3^{\circ} \mathrm{C}$ a $25^{\circ} \mathrm{C}$. Os resultados mostraram que as tintas apresentam temperaturas mínimas de formação de filme de $0^{\circ} \mathrm{C}$.

\subsubsection{Envelhecimento acelerado}

As propriedades avaliadas após o envelhecimento foram aspecto, brilho, cor e os resultados estão apresentados a seguir:

\section{a) Avaliação de alteração do brilho}

Determinada em um medidor de brilho, marca Byk-Gardner, Inc., com angulo de $60^{\circ}$ (ASTM-D 523-89). Os resultados médios obtidos, de 6 determinações, e os respectivos desvios-padrão encontram-se apresentados na Tabela 5.11 e os resultados individuais apresentados na Tabela A.III, no ANEXO A. 
Tabela 5. 11 : Determinação do brilho, sem e após envelhecimento acelerado

\begin{tabular}{|c|c|c|c|c|c|c|c|}
\hline \multirow{3}{*}{$\begin{array}{l}\text { Tipo de } \\
\text { resina }\end{array}$} & \multirow{3}{*}{$\begin{array}{c}\text { Thintas } \\
(P V C \\
\%)\end{array}$} & \multicolumn{2}{|c|}{$\begin{array}{l}\text { sem } \\
\text { envelhecimento }\end{array}$} & \multicolumn{4}{|c|}{ após envelhecimento } \\
\hline & & media & \multirow[b]{2}{*}{$\begin{array}{l}\text { desvio } \\
\text { padrão }\end{array}$} & \multicolumn{2}{|c|}{$300 \mathrm{~h}$} & \multicolumn{2}{|c|}{$600 \mathrm{~h}$} \\
\hline & & media & & média & $\begin{array}{l}\text { desvio } \\
\text { padrão }\end{array}$ & média & $\begin{array}{l}\text { desvio } \\
\text { padrão }\end{array}$ \\
\hline \multirow{4}{*}{$\begin{array}{l}\text { Estireno } \\
\text {-acrílico }\end{array}$} & 75 & 2,20 & 0,05 & 2,20 & 0,10 & 2,30 & 0,16 \\
\hline & 60 & 2,00 & 0,04 & 2,00 & 0,00 & 2,10 & 0,00 \\
\hline & 25 & 30,1 & 1,68 & 14,5 & 1,80 & 11,0 & 0,85 \\
\hline & 0 & 119,4 & 5,96 & 89,4 & 6,94 & - & - \\
\hline \multirow{5}{*}{$\begin{array}{l}\text { Acrílico } \\
\text { puro }\end{array}$} & 75 & 2,40 & 0,10 & 2,20 & 0,15 & 2,20 & 0,00 \\
\hline & 60 & 2,20 & 0,05 & 2,20 & 0,05 & 2,20 & 0,00 \\
\hline & 40 & 2,50 & 0,04 & 2,50 & 0,04 & 3,70 & 0,12 \\
\hline & 25 & 24,0 & 0,22 & 10,6 & 1,12 & - & - \\
\hline & 0 & 114,6 & 2,36 & 107,4 & 1,54 & - & - \\
\hline
\end{tabular}

Os resultados obtidos mostram que tintas de $P V C$ elevados (60\% e $75 \%$ ), de acabamento fosco não apresentaram alteração significativa no brilho, enquanto que, tintas de $P V C$ baixos $(P V C<40 \%$ e resina superior a $17 \%)$ apresentaram alteração significativa do brilho. Nota-se que quanto menor o PVC, maior o teor de polímero, maior a susceptibilidade à ação da radiação ultravioleta.

b) Avaliação visual da alteração da cor com base na escala cinza

Os resultados médios obtidos, da avaliação feita em 2 corpos-de-prova, estão apresentados na Tabela 5.12. 
Tabela 5. 12 : Avaliação visual após envelhecimento acelerado

\begin{tabular}{|c|c|c|c|}
\hline \multirow[t]{2}{*}{ Tipo de resina } & \multirow{2}{*}{$\begin{array}{l}\text { Tinta } \\
(P V C \%)\end{array}$} & \multicolumn{2}{|c|}{$\begin{array}{c}\text { Avaliaça colorimetrica visual, } \\
\text { com base na escala cinza }\end{array}$} \\
\hline & & $300 \mathrm{~h}$ & $600 \mathrm{~h}$ \\
\hline \multirow{5}{*}{ Estireno-acrílico } & 75 & 5 & 5 \\
\hline & 60 & 5 & 5 \\
\hline & 40 & 5 & 5 \\
\hline & 25 & $4 / 5$ & 4 \\
\hline & $\mathbf{0}$ & $4 / 5$ & 4 \\
\hline \multirow{5}{*}{ Acrílico puro } & 75 & 5 & 5 \\
\hline & 60 & 5 & 5 \\
\hline & 40 & 5 & 5 \\
\hline & 25 & 5 & 5 \\
\hline & 0 & 5 & 5 \\
\hline
\end{tabular}

Legenda: $5=$ sem alteração

4 = suave alteração

Esta propriedade foi avaliada apenas visualmente por não ter sido observadas visualmente alterações significativas na cor; todas as tintas à base de resina acrílica pura e as tintas à base de estireno-acrílico de $P V C$ 40\%, 60\% e 75\% não apresentaram nenhuma alteração visível. Apenas as tintas de $P V C 25 \%$ e $0 \%$, à base de estirenoacrílico, apresentaram suave alteração na cor.

O ensaio de envelhecimento artificial mostrou que as tintas e o verniz à base de resina estireno/acrílica apresentam maior susceptibilidade à radiação ultravioleta do que a resina acrílica pura, e que de modo geral ambos os tipos de tinta, de PVC baixo, são susceptíveis à radiação ultravioleta.

Os resultados obtidos também mostram que os dois tipos de tintas, do estudo exploratório, não apresentam as mesmas características dos dois tipos de tintas equivalentes estudados nesta fase, mostrando que tintas de mesmo tipo genérico mas constituídos por diferentes monômeros acrílicos não apresentam o mesmo desempenho, 
conforme indicado pelos diferentes valores de $\mathrm{Tg}$. Os resultados obtidos devem ser correlacionados aos resultados obtidos na exposição ao intemperismo natural.

\subsubsection{Permeabilidade ao vapor de água}

Da mesma forma que no estudo exploratório o ensaio foi realizado conforme a norma ASTM 1653-91a e os resultados obtidos estão apresentados na Tabela 5.13 a seguir:

Tabela 5. 13 : Resultados de permeabilidade ao vapor de água

\begin{tabular}{|c|c|c|}
\hline \multirow{2}{*}{$\begin{array}{l}\text { Tintas } \\
(P V C \%)\end{array}$} & \multirow{2}{*}{$\begin{array}{c}\text { Corpo-de-prova } \\
\mathrm{N}^{\mathrm{o}}\end{array}$} & Permeabilidade (ng/(Pa,s,m)) \\
\hline & & Temp. $23 \%$ e U.R. $50 \%$ \\
\hline \multirow{5}{*}{75} & 1 & 0,2329 \\
\hline & 2 & 0,3193 \\
\hline & 3 & 0,2829 \\
\hline & média & 0,2783 \\
\hline & Desvio padrão & 0,04 \\
\hline \multirow{5}{*}{60} & 1 & 0,0076 \\
\hline & 2 & 0,0081 \\
\hline & 3 & 0,0092 \\
\hline & média & 0,0083 \\
\hline & Desvio padrão & 0,0008 \\
\hline \multirow{5}{*}{40} & 1 & 0,0111 \\
\hline & 2 & 0,0103 \\
\hline & 3 & 0,0103 \\
\hline & média & 0,0106 \\
\hline & Desvio padrão & 0,0005 \\
\hline \multirow{5}{*}{25} & 1 & 0,0115 \\
\hline & 2 & 0,0110 \\
\hline & 3 & 0,0104 \\
\hline & média & 0,0110 \\
\hline & Desvio padrão & 0,0006 \\
\hline \multirow{5}{*}{$\mathbf{0}$} & 1 & 0,0185 \\
\hline & 2 & 0,0172 \\
\hline & 3 & 0,0170 \\
\hline & média & 0,0176 \\
\hline & Desvio padrão & 0,0008 \\
\hline
\end{tabular}


Os resultados obtidos para a tinta acrílica pura mostram que a permeabilidade ao vapor de água é função da sua formulação e que quanto maior o teor de resina e menor o $P V C$ maior é a permeabilidade ao vapor de água, com exceção da tinta de $P V C 75 \%$. A tinta com a relação de $P V C$ mais próxima que é a de $60 \%$ apresenta permeabilidade 33 vezes inferior à de $P V C$ 75\%, mostrando que nesta faixa houve uma inversão desta propriedade que pode ser resultado das dimensões dos poros da película de tinta, os quais foram determinados posteriormente. Os resultados parecem mostrar que a tinta de $P V C 75 \%$ esta abaixo do valor do $P V C$ crítico, que é o ponto onde não há resina suficiente para preencher os vazios existentes entre as partículas de pigmento, resultando em película de elevada porosidade e baixa coesão, conforme mostrado pelo resultado de lavabilidade que é baixo, de 31 ciclos.

\subsubsection{Ensaios no sistema concreto/pintura}

Em todos os corpos-de-prova para ensaio foram aplicadas duas demãos de tinta de $P V C$ $25 \%, 40 \%, 60 \%$ e $75 \%$, resultando em espessura da película úmida de $200 \mu \mathrm{m} /$ demão equivalentes a aproximadamente $380 \mathrm{~g} / \mathrm{m}^{2}$ de material. Para a tinta de $P V C \quad 0 \%$ (verniz) foram aplicadas duas demãos do material, resultando em espessura da película úmida de $160 \mu \mathrm{m} /$ demão equivalentes a aproximadamente $250 \mathrm{~g} / \mathrm{m}^{2}$ de material. A quantidade de tinta aplicada foi controlada por pesagem e a espessura úmida determinada por meio de medidor com dentes em forma de degraus.

Todos os corpos-de-prova, extraídos de painéis de concreto (moldados conforme apresentado no ANEXO B) foram estucados com uma argamassa de cimento e areia fina, na proporção de 1,0:2,8 para concreto de $F$ ck=20MPa e 1,0:1,4 para concreto com Fck=40MPa, visando o tamponamento das irregularidades provocadas pelo "efeito forma", evitando assim a descontinuidade da pintura . 


\subsubsection{Absorção de água por capilaridade}

Os resultados médios e os desvios-padrão, de 4 determinações, obtidos em concretos de fck $=20 \mathrm{MPa}$, sem e com pintura, encontram-se apresentados na Tabela 5. 14 ilustrados na Figura 5. 17 e os resultados individuais apresentados na Tabela A.IV, no ANEXO A. Os resultados médios e os desvios-padrão, de 4 determinações, obtidos para concretos de fck $=40 \mathrm{MPa}$, sem e com pintura, apresentados na Tabela 5.15 e ilustrados na Figura 5. 18 e os resultados individuais apresentados na Tabela A.V, no ANEXO A.

Tabela 5. 14: Absorção de água por capilaridade concreto/ pintura Concreto $\mathrm{fck}=20 \mathrm{MPa}$

\begin{tabular}{|c|c|c|c|c|c|c|c|c|c|}
\hline \multirow{3}{*}{$\begin{array}{c}\text { Tipe de tinta } \\
(P V C \%)\end{array}$} & \multicolumn{9}{|c|}{ Valores médios de absorcão de água por capilaridade $(\%)$} \\
\hline & \multicolumn{9}{|c|}{ Horas de exposicão } \\
\hline & 1 & 3 & 5. & 6. & 24 & 48 & 72 & 96 & 168 \\
\hline Referência & 1,58 & 2,24 & 2,55 & $2, \overline{55}$ & 3,36 & 3,50 & 3,55 & 3,56 & 3,64 \\
\hline 75 & 0,43 & 0,65 & 0,86 & 0,94 & 2,21 & 2,93 & 3,21 & 3,28 & 3,42 \\
\hline 60 & 0,17 & 0.25 & 0,36 & 0.39 & 0.91 & 1,42 & 1.82 & 2.09 & 2,51 \\
\hline 40 & 0,07 & 0,13 & 0,19 & 0,23 & 0,51 & 0,85 & 1,16 & 1,41 & 1,97 \\
\hline 25 & 0,05 & 0,11 & 0,15 & - & 0,50 & 0,68 & 0,89 & 1.09 & 1,52 \\
\hline 0 & 0,05 & 0,05 & 0,11 & $0, \overline{09}$ & 0,11 & 0,17 & 0,22 & 0.25 & 0,32 \\
\hline
\end{tabular}

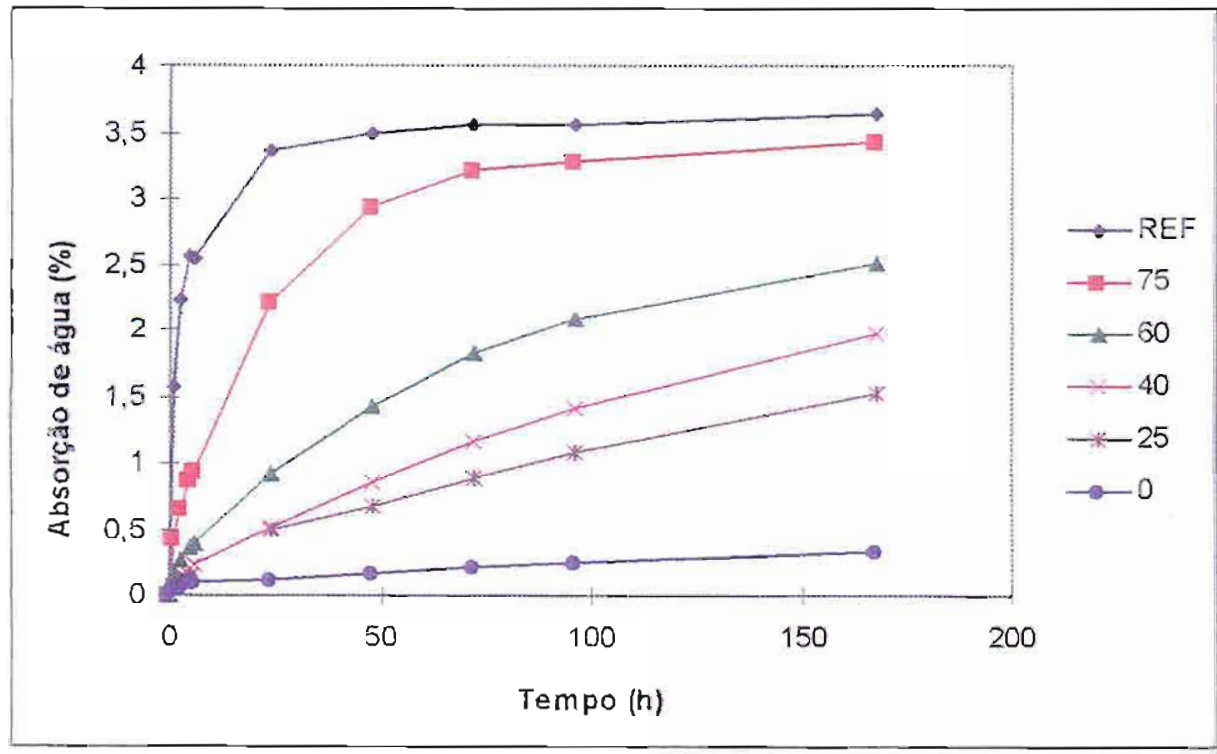

Figura 5. 17 : Absorção de água por capilaridade de concretos (fck $=20 \mathrm{MPa}$ ), com 
Tabela 5, 15 : Absorção de água por capilaridade concreto / pintura

\section{Concreto fck $=40 \mathrm{MPa}$}

\begin{tabular}{|c|c|c|c|c|c|c|c|c|c|}
\hline \multirow{3}{*}{$\begin{array}{c}\text { Tipo de tinta } \\
(P / C \%)\end{array}$} & \multicolumn{9}{|c|}{ Valores médios de absorcăo de agua por capilaridade (\%) } \\
\hline & \multicolumn{9}{|c|}{ Horas de exposiçáo } \\
\hline & 1 & 3 & 5 & 6 & 24 & 48 & 72 & 96 & 168 \\
\hline Referência & 0,48 & 0,61 & 0,69 & 0,78 & 1,21 & 1,43 & 1,52 & 1,56 & 1,64 \\
\hline 75 & 0,28 & 0,34 & 0,41 & 0,45 & 0,70 & 0,91 & 1,06 & 1,16 & 1,28 \\
\hline 60 & 0,16 & 0,19 & 0,25 & 0,27 & 0,48 & 0,70 & 0,87 & 0.97 & 1,13 \\
\hline 40 & 0,07 & 0,12 & 0,16 & 0,20 & 0,39 & 0,65 & 0,84 & 0,96 & $\mathrm{I}, 2 \mathrm{I}$ \\
\hline 25 & 0,06 & 0,13 & 0,18 & - & 0,47 & 0,59 & 0,75 & 0,89 & 1,17 \\
\hline 0 & 0,04 & 0,05 & 0,07 & 0,08 & 0,11 & 0,15 & 0,20 & 0,24 & 0,33 \\
\hline
\end{tabular}

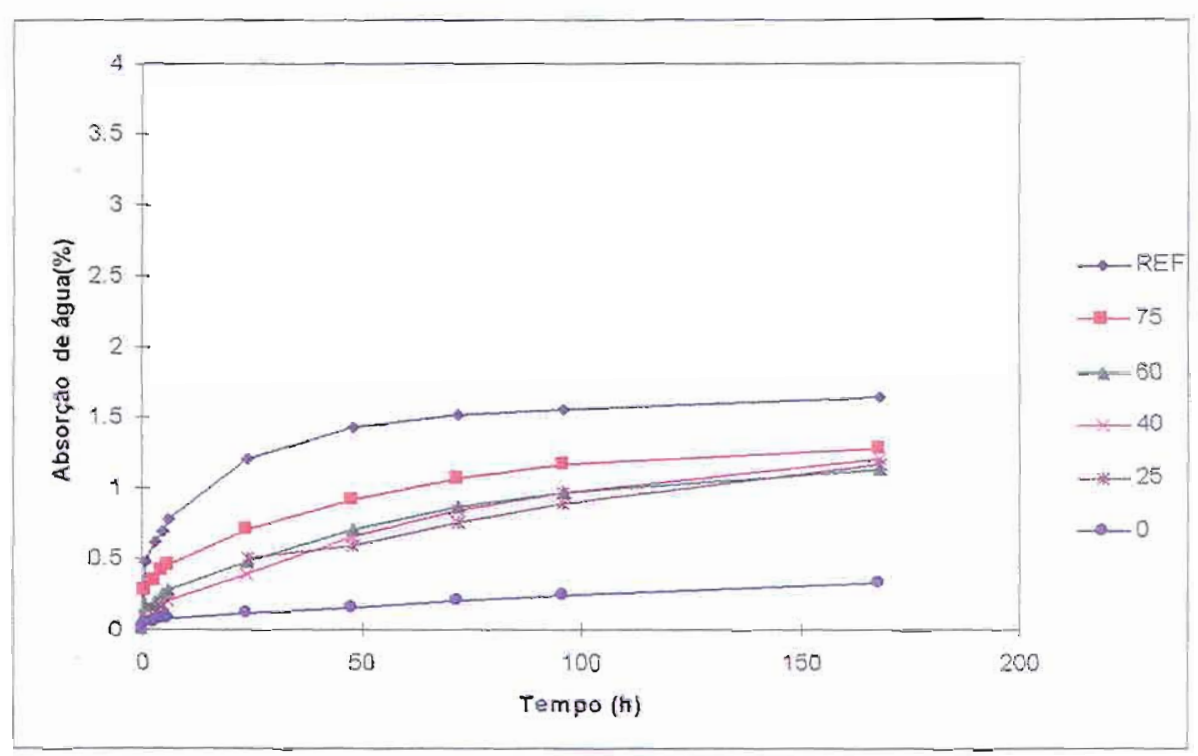

Figura 5. 18 : Absorção de água por capilaridade de concretos (fck $=40 \mathrm{MPa}$ ), com

\section{e sem pintura}

Os resultados obtidos, em concretos com fck $=20 \mathrm{MPa}$, mostram que corpos-de-prova pintados com as 4 tintas ( PVC 25\%, 40\%, 60\% e 75\%) apresentam absorção de água inferior ao concreto não pintado. Quanto menor o $P V C$ da tinta, maior o teor de resina e menor a absorção de água por capilaridade. A tinta de PVC $0 \%$, que na realidade é o verniz, praticamente não apresentou absorção de água; a redução é superior a 10 vezes. Em concretos com fck $=40 \mathrm{MPa}$, comparando-se as médias obtidas nos ensaios, verificase através da análise de variância (ANOVA) que, a um nivel de significância de 5\%, 
não existe diferença de absorção entre concretos pintados com as 4 tintas. Verifica-se também que, existe diferença de absorção entre os concretos pintados com as 4 tintas e a referência sem pintura. Todas as tintas reduzem a absorção de água por capilaridade dos concretos de fck=40 MPa; entretanto, não se observa uma diferenciação nítida de absorção entre o uso de um ou outro tipo de pintura. O verniz, do mesmo modo que no caso anterior, reduziu a absorção de água por capilaridade de modo significativo; de 2 a 3 vezes.

Pode-se concluir que as pinturas protegem os concretos contra a penetração de água por capilaridade e que em concretos de fck=20 MPa o grau de proteção das tintas varia em função da composição. Quanto maior o teor de resina, menor o $P V C$, maior a proteção contra a penetração de água por capilaridade. Para concretos de fck $=40 \mathrm{MPa}$, as pinturas oferecem proteção contra a penetração de água por capilaridade, no entanto, não se observa diferenciação nítida na capacidade de proteção. $\mathbf{A}$ análise de variância realizada não mostrou diferenças entre os diferentes tipos de pintura. $O$ concreto de fck $=40 \mathrm{MPa}$ por si só já apresenta menor velocidade de absorção de água por capilaridade.

\subsubsection{Evaporação de água}

Os resultados médios e os desvios-padrão de 4 determinações, obtidos em concretos de $\mathrm{fck}=20 \mathrm{MPa}$, sem e com pintura, encontram-se apresentados na Tabela 5. 16 e ilustrados na Figura 5. 19 e os resultados individuais apresentados na Tabela A.VI, no ANEXO A. Os resultados médios e os desvios-padrão, de 4 determinações, obtidos para concretos de fck=40 MPa, sem e com pintura, estão apresentados na Tabela 5. 17 e ilustrados na Figura 5. 20 e os resultados individuais apresentados na Tabela A.VII, no ANEXO A. 

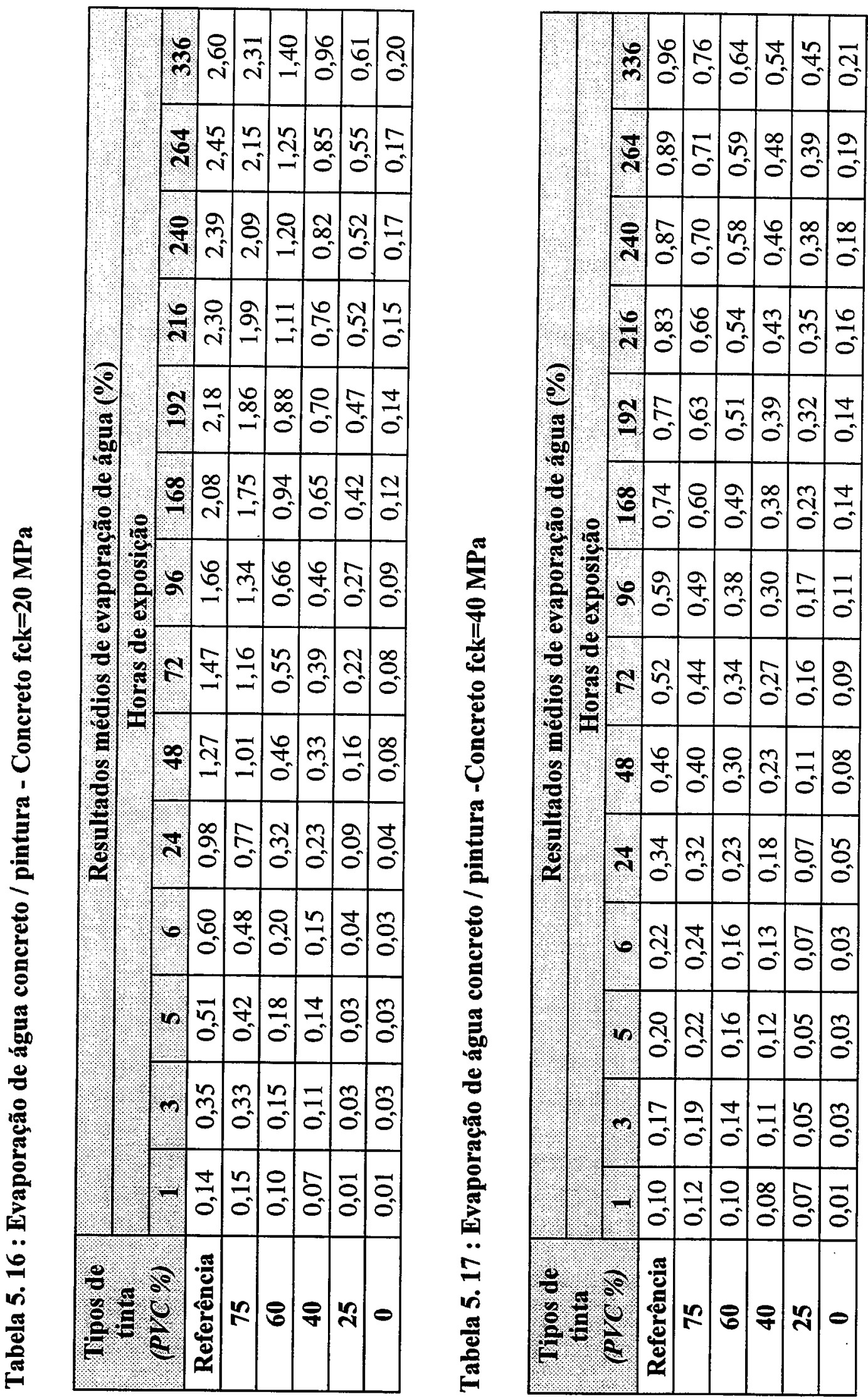


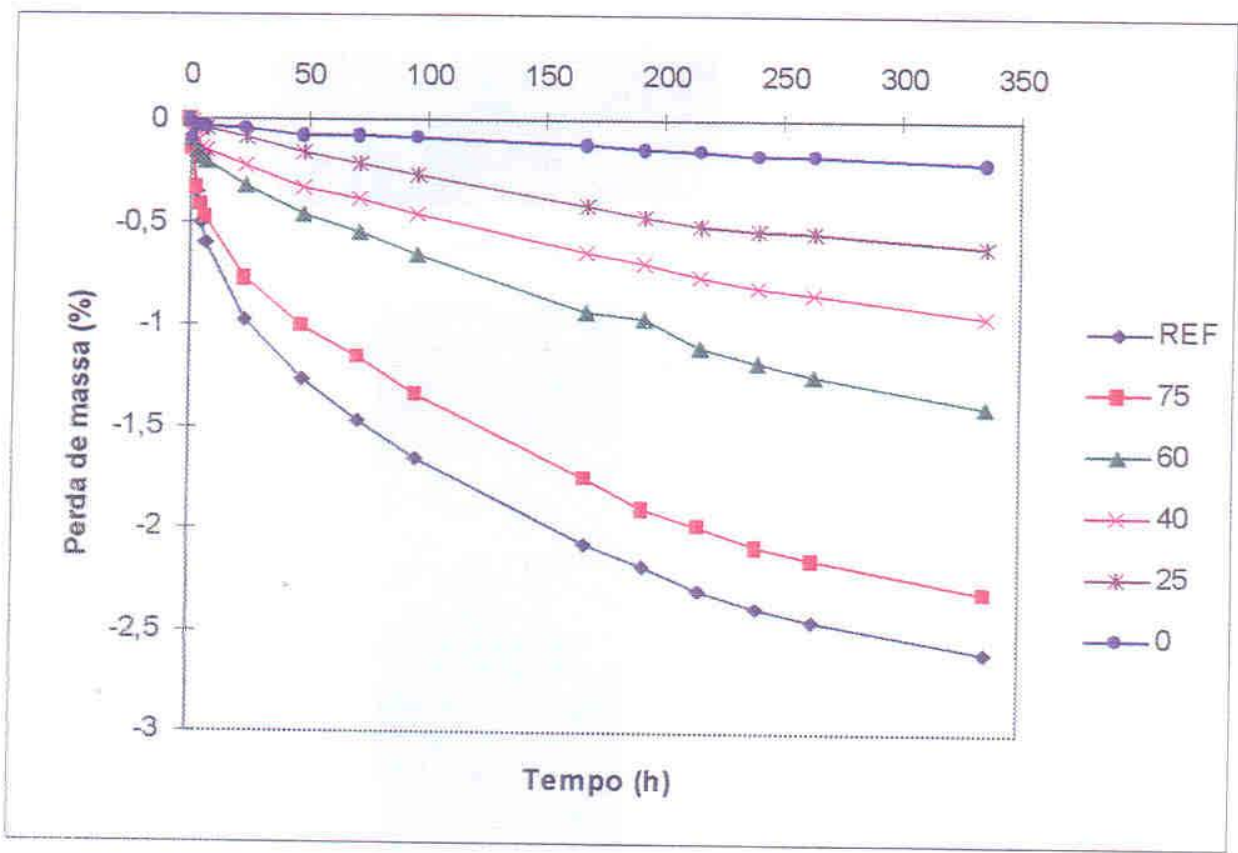

Figura 5. 19: Evaporação de água de concretos de fck=20 $\mathrm{MPa}$, de referência e com pintura

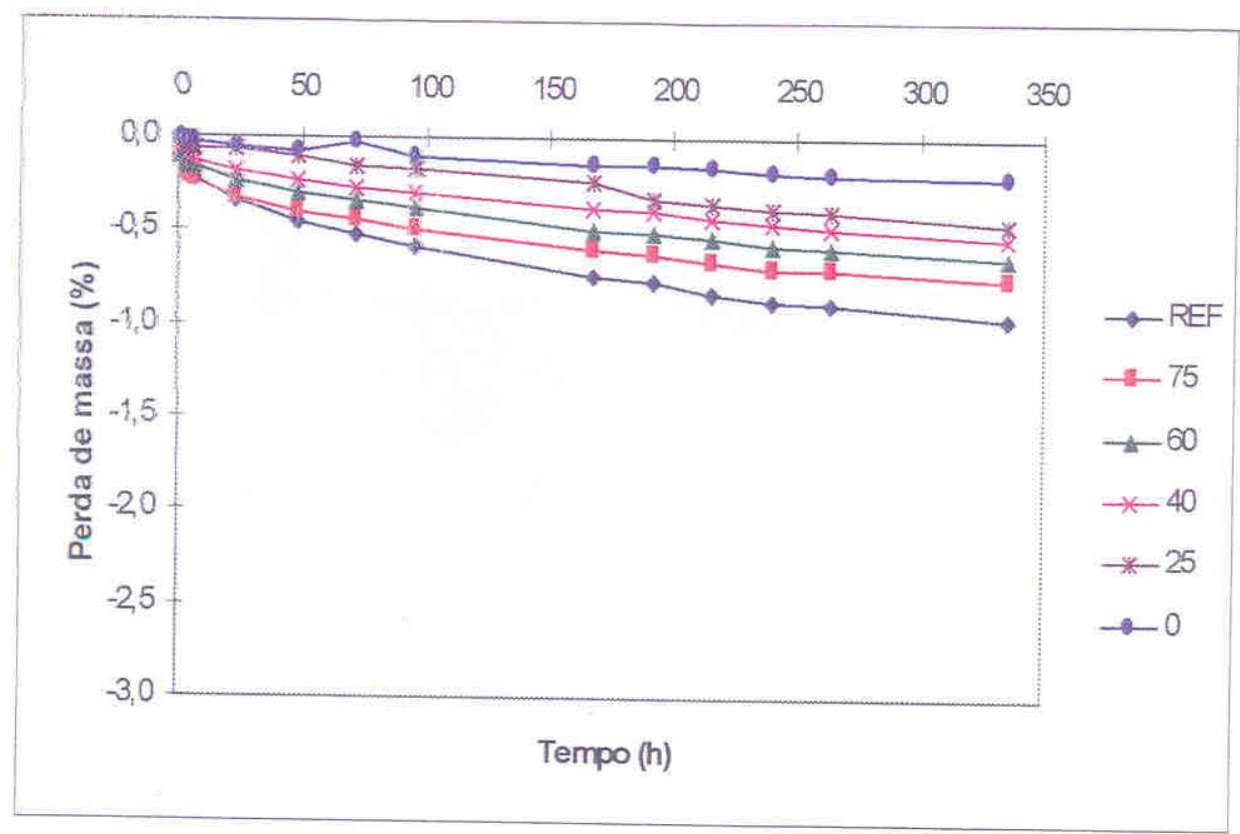

Figura 5. 20 : Evaporação de água de concretos de fck=40 MPa, de referência e com pintura 
Conforme mostrado no ensaio de absorção de água por capilaridade, a aplicação de tinta reduz a velocidade de penetração de água; os resultados obtidos mostram que os concretos pintados com tinta de $P V C 75 \%$ quase consegue chegar à saturação após 168 horas de contato com um filme de água, enquanto que os concretos pintados com as outras tintas não conseguem chegar à saturação após o mesmo período de exposição. Desta forma, com exceção dos corpos-de-prova pintados com tinta de $P V C 75 \%$, o ensaio de evaporação foi iniciado com corpos-de-prova não saturados com água.

Os resultados obtidos neste ensaio mostram que corpos-de-prova pintados com tintas de baixo PVC apresentam menor velocidade de perda de água comparativamente aos corposde-prova sem pintura, usados como referência, tanto em concretos de fck $=20 \mathrm{MPa}$ como os de $40 \mathrm{MPa}$. Quanto menor o PVC da tinta, maior o teor de resina e menor a velocidade de perda de massa por evaporação. A perda de massa determinada nesse ensaio representa apenas parte da água existente no interior dos corpos-de-prova; a outra parte devido a gradiente de concentração de umidade, é redistribuída no interior dos mesmos.

O procedimento usado não foi o mais adequado para estudar o mecanismo de perda de água através da pintura, pelo fato dos corpos-de-prova ensaiados não terem atingido a condição de saturação, onde existe uma condição de umidade uniforme. Para que o ensaio de evaporação seja válido, os corpos-de-prova deveriam ser mantidos em contato com a água até a saturação. Pelo fato da absorção de água por capilaridade, em concretos pintados com tintas de $P V C$ inferior a $60 \%$, ser muito lenta, a condição de saturação só seria atingida após meses ou anos, o que inviabilizou este procedimento. 
Nas Figura 5.21 e Figura 5.22 estão reunidas as curvas de absorção de água e de perda de água, expressos em $\mathrm{kg} / \mathrm{m}^{2}$. Observa-se que tanto os concretos sem pintura ou pintados, com as diferentes formulações de tinta, apresentam velocidade de absorção de água maior do que de perda de água; além disso, o concreto de fck=40 $\mathrm{MPa}$ apresenta menor capacidade de absorção de água por capilaridade e, portanto, de perda de água do que o concreto de $f c k=20 \mathrm{MPa}$. A baixa velocidade de perda de água leva a concluir que a água residual presente no concreto só é possivel de ser eliminada após meses de secagem, em ambiente com umidade relativa inferior a 70\%. O fenômeno da sucção capilar já foi estudado por diversos autores e, conforme SASSE; HONSINGER (1990) é resultado de forças capilares ou adsorptivas e verificada em casos onde a molhagem da superficie ocorre sem pressão externa. Para eles o estudo da secagem é de extrema importância em concretos tratados pelo fato da água líquida acumular se abaixo da área tratada devido à condensação o que pode resultar no aparecimento de falhas em pintura, como fungos e empolamentos. As curvas de absorção e de secagem obtidas neste estudo apresentam o mesmo comportamento que do observado por LEEMING (1990). Conforme esse autor o fenômeno de "respiro" ou melhor o de entrada e saída de água no concreto é de elevada importância na compreensão dos mecanismos de transporte; no entanto, existem poucos métodos para a sua medida. 


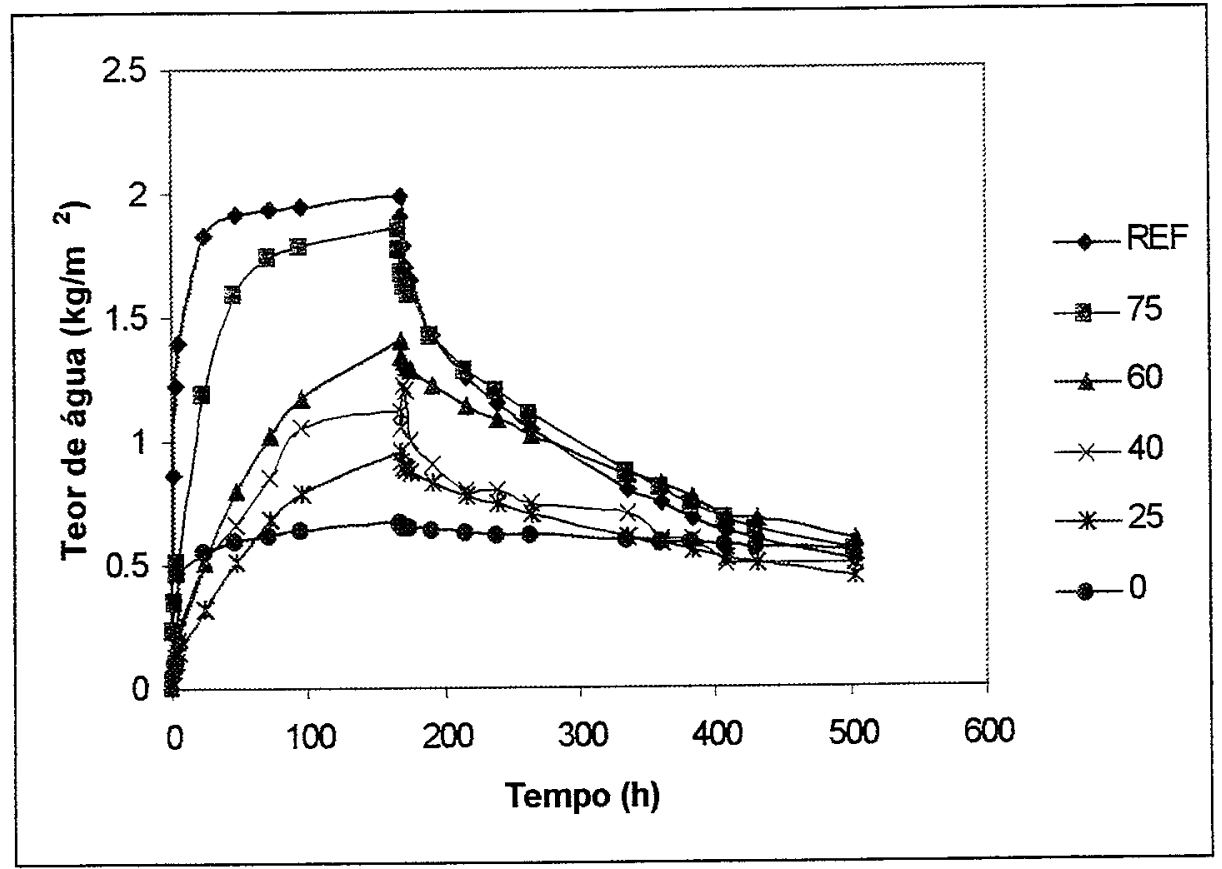

Figura 5. 21 : Variação do teor de água ao longo do tempo, de concretos pintados (fck=20 MPa)

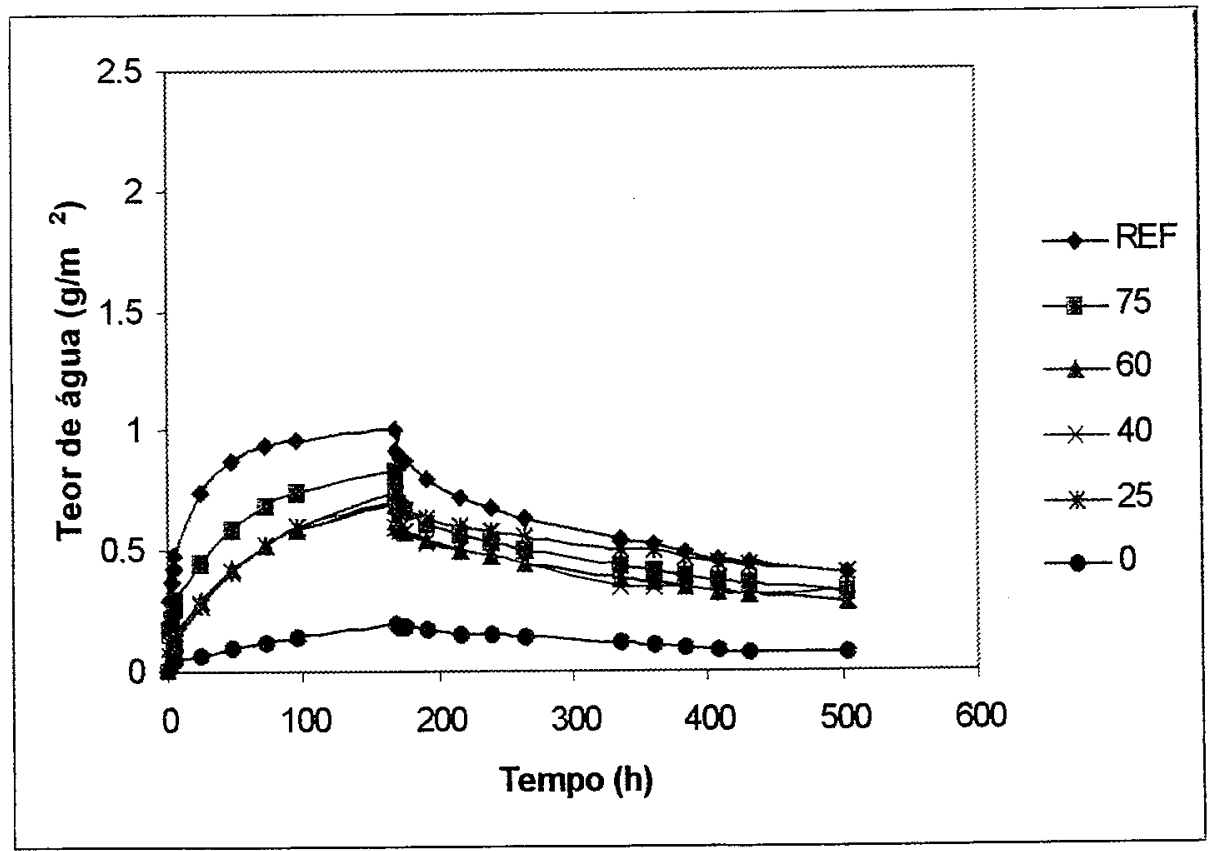

Figura 5. 22 : Variação do teor de água ao longo do tempo, de concretos pintados

$$
(\mathbf{f c k}=40 \mathrm{MPa})
$$




\subsubsection{Resistência à penetração de íons cloreto}

A penetração de íons cloretos através dos poros do concreto ocorre em forma de solução, com estes íons dissolvidos em água, como aquela decorrente da maresia. Os principais mecanismos de transporte de água ou de soluções para o interior do concreto ocorrem por absorção capilar e por difúsão de agentes dissolvidos.

Foram desenvolvidos procedimentos de ensaio para a avaliação da resistência à penetração dos íons cloreto através dos poros do concreto, sendo a mais difundida a proposta pela Norma ASTM 1202-94 que é um ensaio acelerado, podendo ser realizado em algumas horas. No estudo, foi definido o uso deste procedimento pelo fato das pinturas serem uma barreira de proteção que reduz a velocidade de penetração do cloreto e por que este método acelerado permite obter resultados em poucas horas. $\mathrm{O}$ procedimento de medida consiste em expor a face pintada dos corpos-de-prova de concreto, de $10 \mathrm{~cm}$ de diâmetro e $5 \mathrm{~cm}$ de espessura, a uma solução de cloreto de sódio e a outra face não pintada a uma solução de hidróxido de sódio. É aplicada uma tensão de $60 \mathrm{~V}$ entre as faces e mede-se a corrente que passa através dos corpos-de-prova a cada 30 minutos, durante 6 horas. A diferença de potencial gera um fluxo de elétrons e, como conseqüência, gera uma corrente elétrica. A partir da integração da curva de corrente em função do tempo é calculada a carga elétrica total que passa pelo corpo-deprova durante esse período. A carga está relacionada com a resistência dos materiais à penetração de íons cloreto que, neste estudo, são os concretos pintados com as tintas e, sem pintura, usados como referência.

Conforme a literatura (ANDRADE, 1993), este método não mede apenas a permeabilidade do concreto ao íon cloreto. O registro da corrente total que passa atravês da célula é função da quantidade e tipo de íons, e não apenas do fluxo dos íons cloreto. 
Assim, para corrigir o efeito do método eletrométrico, determinou-se o teor de cloreto presente na solução de cloreto de sódio, antes e após a aplicação da tensão, usando eletrodo de íon seletivo (UEMOTO et al,1995).

A norma ASTM C 1202-94 apresenta critérios qualitativos para avaliar a penetração de íons cloreto através de concretos, com base na carga passante, conforme apresentado na Tabela 5. 18. Com base nesses critérios pode-se dizer que os concretos usados no estudo, de resistência à compressão de $20 \mathrm{MPa}$ e de $40 \mathrm{MPa}$, são classificados respectivamente como de elevada e de moderada penetrabilidade ao íon cloreto.

Tabela 5. 18 : Penetrabilidade do íon cloreto em concreto com base na carga passante

\begin{tabular}{|c|c|c|}
\hline Carga passante (Coulombs) & Cloretos migrados (ppm) & Penetrabilidade dos ions cloreto \\
\hline$>4000$ & $>5200$ & elevada \\
\hline $2000-4000$ & $2600-5200$ & moderada \\
\hline $1000-2000$ & $1300-2600$ & baixa \\
\hline $100-1000$ & $130-1300$ & muito baixa \\
\hline$<100$ & $<130$ & desprezível \\
\hline
\end{tabular}

Os resultados de penetração de íon cloreto, em concretos de $20 \mathrm{MPa}$ e de $40 \mathrm{MPa}$, obtidos pelo método eletrométrico e analítico estão apresentados Tabela 5. 19 na Tabela 5. 20. Constam nestas Tabelas os valores de medida de carga passante e de teor de cloreto remanescente presente na solução de cloreto de sódio. A penetração também foi expressa como teor de cloreto migrado, valor obtido pela diferença entre a concentração inicial de cloreto e os cloreto remanescente, após a aplicação da tensão. 
Tabela 5. 19 : Resultados de resistência à penetração de íons cloreto - Concreto: $f c k=20$ MPa

\begin{tabular}{|c|c|c|c|c|c|}
\hline \multirow{2}{*}{$\begin{array}{l}\text { Tipos de } \\
\text { tinta } \\
(P V C \%)\end{array}$} & \multirow{2}{*}{$\begin{array}{l}\text { CP } \\
\mathbf{N}^{\circ}\end{array}$} & \multicolumn{2}{|c|}{$\begin{array}{c}\text { Permeabilidade com base em } \\
\text { carga passante }\end{array}$} & \multicolumn{2}{|c|}{$\begin{array}{l}\text { Permeabilidade com base } \\
\text { em cloretos migrados }\end{array}$} \\
\hline & & $\begin{array}{l}\text { Carga } \\
\text { (Coulombs) }\end{array}$ & $\begin{array}{c}\text { Avaliacão } \\
\text { qualitativa } \\
\text { (ASTM C1202) }\end{array}$ & $\begin{array}{l}\text { Cloretos } \\
\text { remanescente } \\
\text { s (ppm) }\end{array}$ & $\begin{array}{l}\text { Cloretos } \\
\text { migrados } \\
\text { (ppm) }\end{array}$ \\
\hline \multirow{5}{*}{ Referência } & 1 & 4706 & - & 12000 & 6300 \\
\hline & 2 & 4703 & - & 12200 & 6100 \\
\hline & 3 & 4982 & - & 12100 & 6200 \\
\hline & média & 4797 & elevada & 12100 & 6200 \\
\hline & desvio padrão & 160 & - & 100 & 100 \\
\hline \multirow{5}{*}{75} & 1 & 3363 & - & 13200 & 5100 \\
\hline & 2 & 3876 & - & 12500 & 5800 \\
\hline & 3 & 3810 & - & 12700 & 5600 \\
\hline & média & 3683 & moderada & 12800 & 5500 \\
\hline & desvio padrão & 279 & - & 360 & 360 \\
\hline \multirow{5}{*}{60} & 1 & 3782 & - & 13100 & 5200 \\
\hline & 2 & 3943 & - & 13000 & 5300 \\
\hline & 3 & 3918 & - & 12900 & 5400 \\
\hline & média & 3881 & moderada & 13000 & 5300 \\
\hline & desvio padrão & 87 & - & 100 & 100 \\
\hline \multirow{5}{*}{40} & 1 & 2253 & & - & - \\
\hline & 2 & 2070 & & - & - \\
\hline & 3 & 1513 & & - & - \\
\hline & média & 1945 & baixa/moderada & - & - \\
\hline & desvio padrão & 385 & & - & - \\
\hline \multirow{5}{*}{25} & 1 & 2864 & - & 14000 & 4300 \\
\hline & 2 & 2670 & - & 14200 & 4100 \\
\hline & 3 & 1178 & - & 16200 & 2100 \\
\hline & média & 2091 & baixa/moderada & 14800 & 3500 \\
\hline & desvio padrão & 652 & - & 1216 & 1216 \\
\hline \multirow{5}{*}{$\mathbf{0}$} & 1 & 1480 & - & 15700 & 2600 \\
\hline & 2 & 1815 & - & 15100 & 3200 \\
\hline & 3 & 854 & - & 16900 & 1400 \\
\hline & média & 1383 & baixa & 15900 & 2400 \\
\hline & desvio padrão & 488 & - & 916 & 916 \\
\hline
\end{tabular}


Tabela 5. 20 : Resultados de resistência à penetração de íons cloreto - Concreto: fck=40 MPa

\begin{tabular}{|c|c|c|c|c|c|}
\hline \multirow{2}{*}{$\begin{array}{c}\text { Tipos de } \\
\text { tinta } \\
(P V C \%)\end{array}$} & \multirow{2}{*}{$\begin{array}{l}\mathbf{C P} \\
\mathrm{N}^{\circ}\end{array}$} & \multicolumn{2}{|c|}{$\begin{array}{c}\text { Permeabilidade com base em } \\
\text { carga passante }\end{array}$} & \multicolumn{2}{|c|}{$\begin{array}{l}\text { Permeabilidade com base } \\
\text { em cloretos migrados }\end{array}$} \\
\hline & & $\begin{array}{c}\text { Carga } \\
\text { (Coulombs) }\end{array}$ & $\begin{array}{l}\text { Avaliacão } \\
\text { qualitativa } \\
\text { (ASTM C1202) }\end{array}$ & $\begin{array}{l}\text { Cloretos } \\
\text { remanescentes } \\
(\text { ppm) }\end{array}$ & $\begin{array}{c}\text { Cloretos } \\
\text { migrados } \\
\text { (pppo) }\end{array}$ \\
\hline \multirow{5}{*}{ Referência } & 1 & 2618 & - & 14600 & 3700 \\
\hline & 2 & 3213 & - & 13700 & 4600 \\
\hline & 3 & 2651 & - & 14600 & 3700 \\
\hline & média & 2827 & moderada & 14300 & 4000 \\
\hline & desvio padrão & 334 & - & 520 & 520 \\
\hline \multirow{5}{*}{75} & 1 & 3066 & - & 13600 & 4700 \\
\hline & 2 & 3180 & - & 13700 & 4600 \\
\hline & 3 & 2030 & - & 14900 & 3400 \\
\hline & média & 2759 & moderada & 14066 & 4233 \\
\hline & desvio padrão & 634 & - & 723 & 723 \\
\hline \multirow{5}{*}{60} & 1 & 2542 & - & 14700 & 3600 \\
\hline & 2 & 2402 & - & 14500 & 3800 \\
\hline & 3 & 3731 & - & 13600 & 4700 \\
\hline & média & 2892 & moderada & 14267 & 4033 \\
\hline & desvio padrão & 730 & - & 586 & 586 \\
\hline \multirow{5}{*}{40} & 1 & 1686 & & & \\
\hline & 2 & 2155 & & & \\
\hline & 3 & 1633 & & & \\
\hline & média & 1825 & baixa & & \\
\hline & desvio padrão & 287 & & & \\
\hline \multirow{5}{*}{25} & 1 & $1540 *$ & - & 15900 & 2400 \\
\hline & 2 & 797 & - & 17000 & 1300 \\
\hline & 3 & 808 & - & 16900 & 1400 \\
\hline & média & 802 & muito baixa & 16600 & 1700 \\
\hline & desvio padrão & 8 & - & 608 & 608 \\
\hline \multirow{5}{*}{$\mathbf{0}$} & 1 & 288 & - & 16200 & 2100 \\
\hline & 2 & 993 & - & 17500 & 800 \\
\hline & 3 & 756 & - & 16500 & 1800 \\
\hline & média & 679 & muito baixa & 16733 & 1567 \\
\hline & desvio padrão & 359 & - & 681 & 681 \\
\hline
\end{tabular}

* Valor descartado com base no critério de Dixon, usando $\alpha=0,05$ 
As tintas de $P V C$ elevado ( $P V C$ de $60 \%$ e de $75 \%$ ) quando aplicadas em concreto de 20 MPa reduzem a penetrabilidade ao íon cloreto, mudando a classificação da ASTM C 1202, de concreto de elevada para moderada penetrabilidade ao íon cloreto. Avaliandose os resultados do ensaio para concretos pintados com tintas de $P V C \quad 60 \%$ e $75 \%$, através da Análise de Variância (ANOVA) a um nível de significância de 5\%, observase que não existe diferença entre as medidas de carga passante do concreto pintado com as essas tintas comparativamente ao concreto de referência sem pintura. A diferença existente no teor de veículo não volátil entre as tintas, de $10,8 \%$ e de $7,10 \%$, não foi suficiente para aumentar a proteção ao concreto de $20 \mathrm{MPa}$.

A aplicação de tinta de $P V C 40 \%$ e $25 \%$, com respectivamente $16,8 \%$ e $21,6 \%$ de veículo não volátil, conforme determinado nos ensaios de caracterização, reduziram a penetrabilidade do íon cloreto no concreto de modo significativo. Com base na classificação da norma ASTM C 1202, o concreto que era classificado como de elevada penetrabilidade ao íon cloreto, com a aplicação da tinta, muda para baixa penetrabilidade a este íon.

Para o concreto de $40 \mathrm{MPa}$, avaliando-se os resultados do ensaio através da Análise de Variância (ANOVA), a um nível de significância de 5\%, observa-se que não existe diferença entre as medidas de carga passante do concreto de referência comparativamente aos concretos pintados com tintas de $P V C 60 \%$ e $75 \%$. Este concreto mesmo sendo protegido com estes dois tipos de pintura, com respectivamente $10,8 \%$ e $7,10 \%$, continuam sendo classificados como de moderada penetrabilidade a cloreto. A aplicação de tintas de $P V C$ baixo, de $40 \%$ e de $25 \%$, com teores de veículo não volátil de $16,8 \%$ e de $21,6 \%$, reduziu a penetrabilidade do ín cloreto, resultando em boa proteção a este concreto. 
A aplicação de tinta de $P V C 0 \%$ (verniz) em concretos de resistência à compressão, de $20 \mathrm{MPa}$ e de $40 \mathrm{MPa}$, reduziu a penetrabilidade do ín cloreto de modo acentuado. Conforme os critérios adotados pela norma ASTM C 1202, os concretos protegidos com o verniz do estudo são classificados como de baixa penetrabilidade ao íon cloreto, provavelmente, devido ao elevado teor de veículo não volátil presente, de $42,1 \%$. De modo geral, a maioria dos vernizes do mercado possuem teores de veículo não volátil entre $10 \%$ a $20 \%$, provavelmente, estes devem apresentar menor capacidade de proteção contra a penetração deste agente agressivo do que este do estudo.

O ensaio permitiu concluir que ambos os concretos, classificados como de elevada e moderada penetrabilidade ao íon cloreto resultaram em sistema de baixa permeabilidade a este ion quando pintados com tintas de baixo $P V C$, de acabamento semi-brilho ou verniz. Os resultados mostram que concretos pintados com tintas de elevado $P V C$, com teores de resina inferior a $11 \%$ de resina, conforme determinado nos ensaios de caracterização, não protegem o concreto contra a penetração do íon cloreto. $O$ estudo realizado anteriormente pela autora com outros sistemas de pintura mostraram que um aumento de número de demãos melhora a proteção ao concreto, principalmente em concretos de baixa resistência mecânica (UEMOTO et al., 1995).

As Figuras 5.23 e Figura 5. 24 ilustram a penetrabilidade do íon cloreto em concretos, sem pintura e pintados, de resistências à compressão de $20 \mathrm{MPa}$ e $40 \mathrm{MPa}$. 


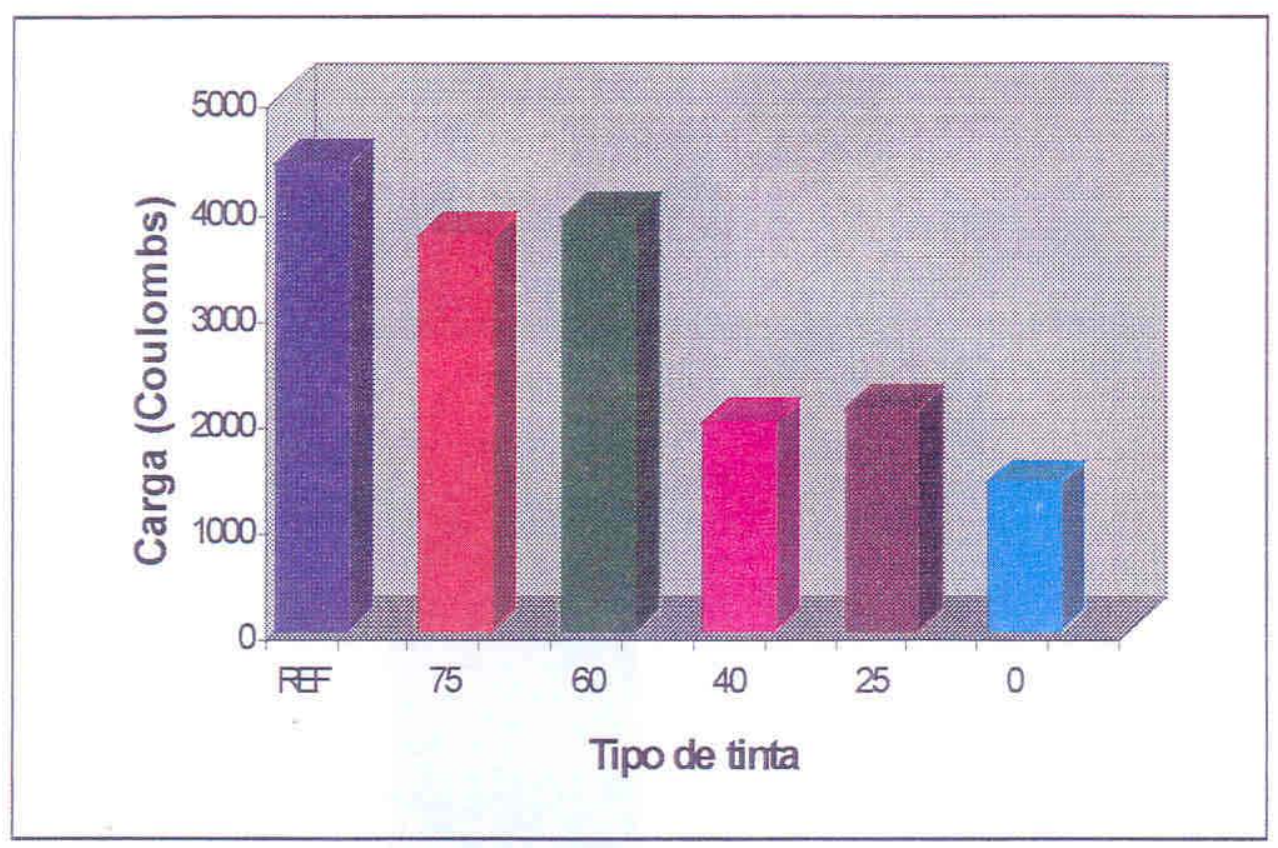

Figura 5. 23 : Penetrabilidade do íon cloreto em concreto de $20 \mathrm{MPa}$, pintado e sem pintura.

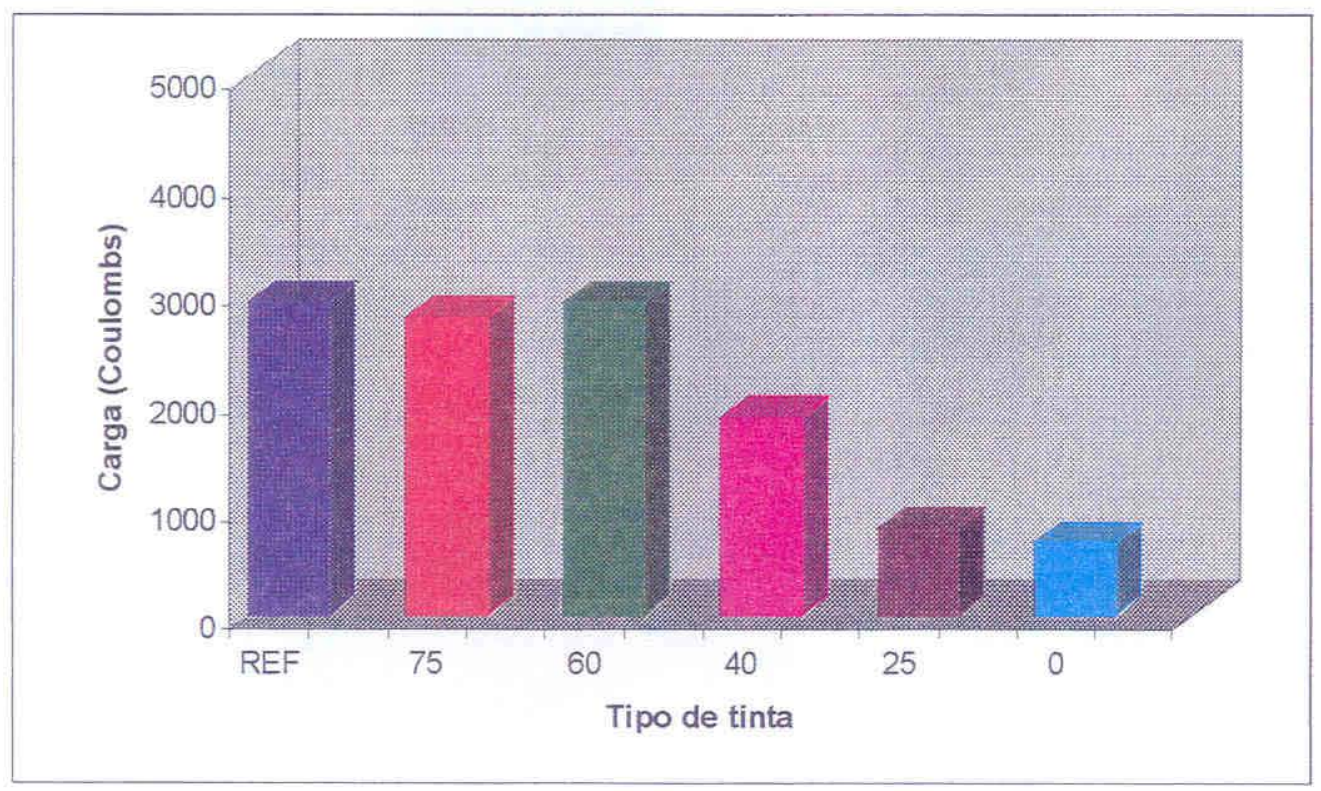

Figura 5. 24 : Penetrabilidade do íon cloreto em concreto de $40 \mathrm{MPa}$, pintado e sem pintura. 
Tendo a norma ASTM C 1202 como critério para a avaliação da permeabilidade ao íon cloreto e com base no estudo realizado pode-se concluir que as pinturas de acabamento fosco, de alto $P V C$, não protegem o concreto contra a penetração deste íon, podendo o efeito ser considerado predominantemente decorativo e não de proteção. A proteção somente é obtida pela aplicação de tintas de acabamento semi-brilho, com baixo PVC. Em caso de necessidade de uso de acabamento fosco pode-se aplicar como $1^{\mathrm{a}}$ demão a tinta semi-brilho e nas outras demãos o acabamento fosco.

\section{Correlação entre a medida da corrente e teor de cloretos remanescentes}

Conforme a revisão da literatura a metodologia apresentada pela norma ASTM C 1202 é questionável. Assim, para corrigir a medida da corrente total, decorrente das migrações, determinou-se também a concentração do teor de cloretos remanescentes. Para estabelecer a correlação existente entre os cloretos remanescentes e a carga passante os 2 conjuntos de dados obtidos nos concretos de referência sem pintura e com pintura, foi traçada uma curva usando a técnica dos mínimos quadrados, cujo coeficiente de correlação obtido é $\mathrm{R}^{2}=0,94$. A equação e a curva resultante apresentada na Figura 5. 25 mostra uma correlação linear positiva entre os dois procedimentos de ensaio. Com base em estudos anteriores realizados com outros concretos e tipos de pintura e com base neste diagrama de dispersão conclui-se que a correlação independe do traço do concreto e do tipo de tinta (UEMOTO et al., 1995).

A partir do diagrama de regressão obteve-se o teor de cloretos migrados equivalentes à carga passante, e apresentado na Figura 5. 18. Estes dados permitem adotar o teor de cloreto, expresso em ppm, para classificar a sua penetrabilidade no concreto. 


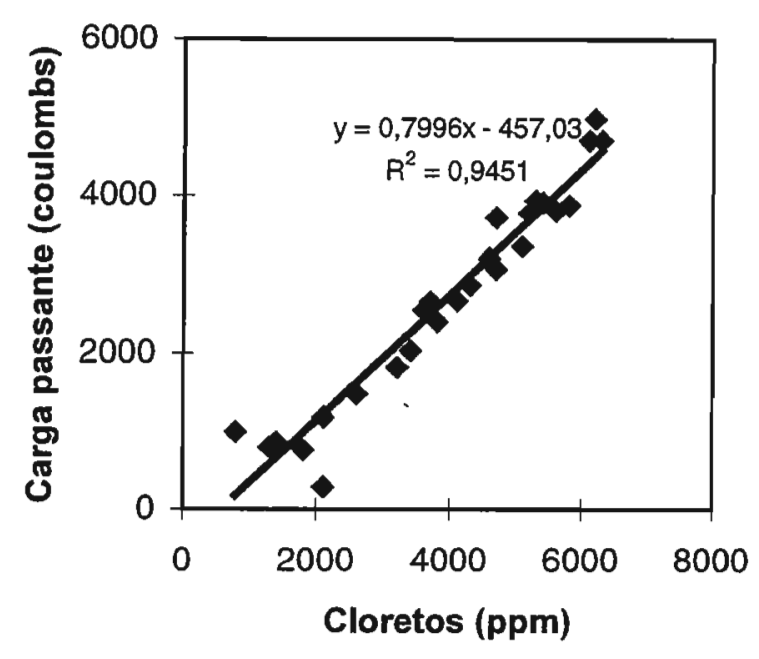

Figura 5. 25 : Correlação entre a medida da corrente e teor de cloretos remanescentes

Apesar da norma americana não determinar o cloreto ele parece válido como medida quantitativa. Os resultados obtidos mostram que existe correlação entre teor de cloreto e carga passante. Provavelmente, pelo fato da migração do cloreto ser muito superior a outras migrações estas últimas não interferem muito na medida.

\subsubsection{Profundidade de carbonatação}

A carbonatação é uma das principais formas de degradação de estruturas de concreto armado no Brasil. Com o objetivo de estudar o efeito da composição das tintas na proteção ao concreto quanto à penetração do $\mathrm{CO}_{2}$, corpos-de-prova, sem e com pintura, com dimensões de $5 \mathrm{~cm} \times 5 \mathrm{~cm} \times 10 \mathrm{~cm}$, extraídos de painéis de concreto, foram expostos em câmara com elevado teor de $\mathrm{CO}_{2}$. A câmara de carbonatação é de circuito aberto e alimentação contínua por meio de um cilindro de gás e ar atmosférico (JOHN, 1995), e foi mantida em ambiente à temperatura de $21,5 \pm 1,5^{\circ} \mathrm{C}$ e umidade no interior da câmara de 80 \%. Embora muitos ensaios acelerados sejam realizados com níveis de concentração mais elevados ( PAPADAKIS et al., 1991), a concentração de $\mathrm{CO}_{2}$ no ensaio foi mantida em $5 \%$, de forma a poder ter um maior número de medidas, antes da 
ocorrência da carbonatação total. A espessura carbonatada do concreto é medida com solução alcoólica de fenolftaleína a 1\%. A faixa de viragem da fenolftaleína é de 8,3 a 10, sendo vermelho-carmim acima dessa faixa e incolor abaixo dessa faixa, que representa a "frente de carbonatação" (HELENE, 1993). A faixa média de 6 determinações de profundidade de penetração, em 3 corpos-de-prova, após 7 dias, 14 dias e 28 dias de exposição na câmara, está apresentada na Tabela 5. 21.A profundidade de penetração de $\mathrm{CO}_{2}$ nos corpos-de-prova de $20 \mathrm{MPa}$ e de $40 \mathrm{MPa}$ está ilustrada na Figura 5. 26 e Figura 5. 27.

Tabela 5. 21 : Profundidade de carbonatação

\begin{tabular}{|c|c|c|c|c|c|c|}
\hline \multirow{3}{*}{$\begin{array}{l}\text { Tipos } \\
\text { detinta } \\
(\mathrm{PVC} \%)\end{array}$} & \multicolumn{6}{|c|}{ Profundidade de carbonatação (mm) } \\
\hline & \multicolumn{2}{|c|}{7 dias de exposição } & \multicolumn{2}{|c|}{14 dias de exposição ${ }^{(2)}$} & \multicolumn{2}{|c|}{28 dias de exposição ${ }^{(2)}$} \\
\hline & $20 \mathrm{MPa}$ & $40 \mathrm{MPa}$ & $20 \mathrm{MPa}$ & $40 \mathrm{MPa}$ & $20 \mathrm{MPa}$ & $40 \mathrm{Mpa}$ \\
\hline Referência & $5-8$ & 1 & $7-8$ & 0 & $8-15$ & 0 \\
\hline 75 & 4-7 & 1 & $5-8$ & 0 & $8-12$ & 0 \\
\hline 60 & $2-3$ & 1 & 2 & 0 & $3-5$ & 0 \\
\hline 40 & - & - & 1 & 0 & $2-4$ & 0 \\
\hline 25 & $2-3$ & 1 & 0 & & $1-2$ & 0 \\
\hline $\mathbf{0}$ & $1-2$ & 0 & 0 & 0 & 1 & 0 \\
\hline
\end{tabular}

Observações:

(1) Ensaio realizado em corpos-de-prova curados durante 6 meses em câmara úmida, e secos durante 3 meses em câmara seca, com umidade relativa de $50 \%$ e temperatura de $25^{\circ} \mathrm{C}$. A pintura foi curada durante 1 mês em ambiente de laboratório.

(2) Ensaio realizado em corpos-de-prova curados durante 1 ano em câmara úmida, e secos durante 15 dias em câmara seca, com umidade relativa de $50 \%$ e temperatura de $25^{\circ} \mathrm{C}$ e 15 dias em estufa à temperatura de $50{ }^{\circ} \mathrm{C}$. A pintura foi curada durante 10 dias em ambiente de laboratório. 


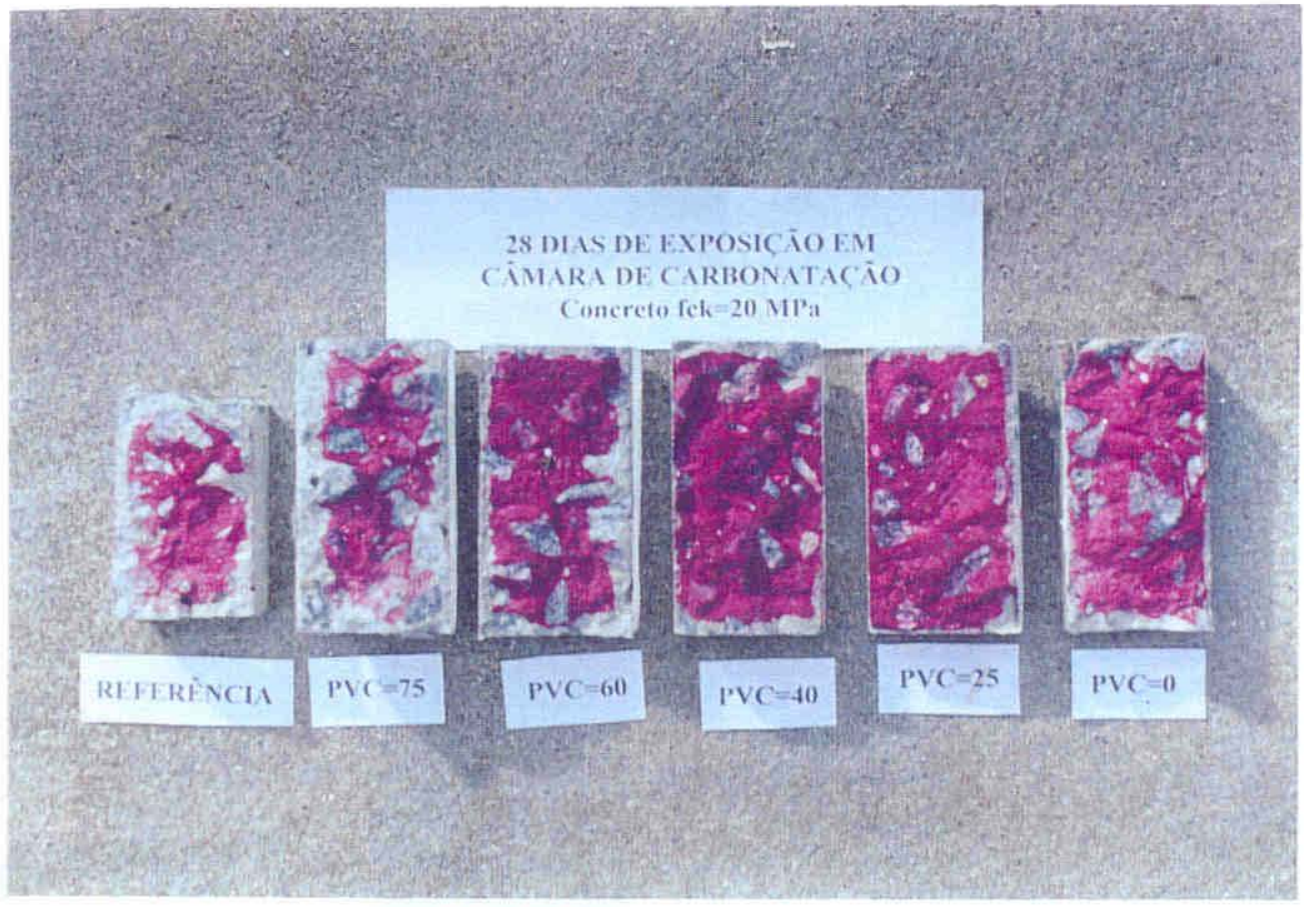

Figura 5. 26 : Profundidade de penetração de $\mathrm{CO}_{2}$ em concreto de $20 \mathrm{MPa}$, após 28 dias de exposição e câmara

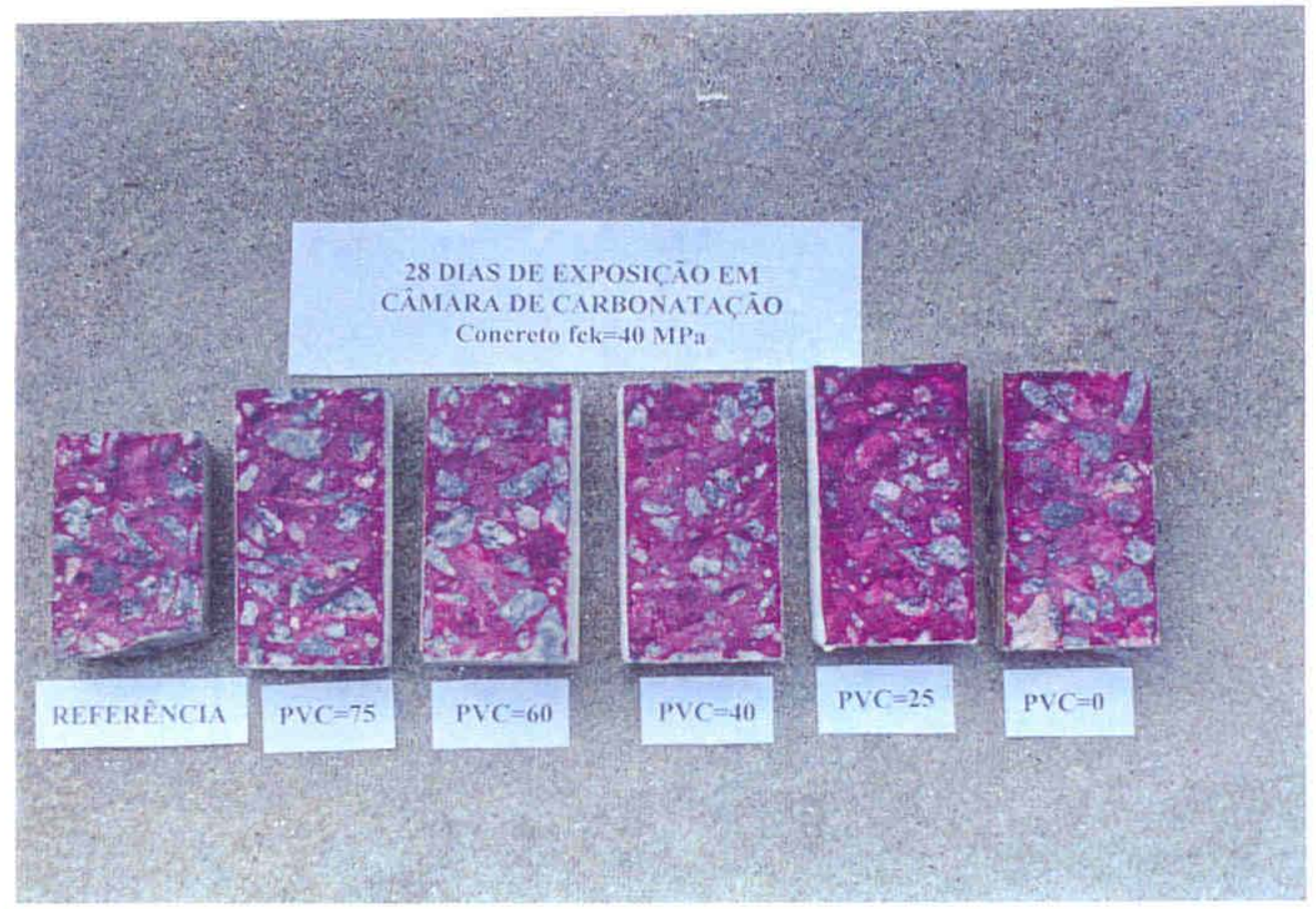

Figura 5. 27 : Profundidade de penetração de $\mathrm{CO}_{2}$ em concreto de $40 \mathrm{MPa}$, após 28 dias de exposição e câmara 
Apesar dos concretos apresentarem agregados graúdos, com dimensão característica inferior a $19 \mathrm{~mm}$, a presença destes próxima à superfície de concreto torna a avaliação, através da medida da profundidade de penetração, apenas qualitativa. A dificuldade observada na realização do ensaio, provavelmente, deve-se ao fato dos corpos-de-prova terem sido moldados em forma de painéis, de apenas $5 \mathrm{~cm}$ de espessura, visando a obtenção de superfícies que simulam o acabamento obtido em obra.

Os resultados obtidos mostram que a tinta de $P V C 75 \%$ praticamente não protege o concreto de fck $=20 \mathrm{MPa}$ contra a penetração do $\mathrm{CO}_{2} ;$ mostram também que a tinta de PVC 60\% já apresenta melhor proteção, apesar de não ser muito significativa. Já as tintas de $P V C 40 \%$ e $25 \%$ apresentam melhor proteção ao concreto. Os resultados obtidos mostram que realmente tintas de $P V C$ elevado não protegem o concreto contra a penetração do $\mathrm{CO}_{2}$, são basicamente decorativas, enquanto que as tintas de $P V C$ baixo apresentam boa proteção. Além disso, o ensaio mostrou que os concretos ricos por si só já apresentam boa resistência à penetração deste agente agressivo.

\subsubsection{Porosidade e distribuição de poros}

\subsubsection{Microscopia eletrônica de varredura (MEV)}

As Figura 5.28 e 5.29, imagem com aumento de 10.000 vezes, ilustram o aspecto das tintas de $P V C 25 \%$ e $75 \%$, respectivamente, obtida pela aplicação de tinta sobre papel tratado com silicone. A micrografia mostra que na tinta, de PVC 25\% (Figura 5.28), a fração resina tem aspecto de uma pasta que envolve quase todos os grãos de pigmento. Os poros maiores observados apresentam diâmetro da ordem de $1 \mu \mathrm{m}$. Na tinta de $P V C 75 \%$ observam-se nitidamente grãos de pigmentos, dando a impressão de não existir a presença de resina e 
que a tinta é descontínua. Essa tinta possivelmente possui o $P V C$ (concentração volumétrica de pigmento) acima do valor crítico. A imagem obtida mostra uma superfície na qual observa-se apenas o empacotamento de pigmentos. Estes dados ilustram porque o $C P V C$ tem sido considerado de importância fundamental nas formulações de tinta pois é neste ponto que as propriedades são abruptamente alteradas (NOLAN \& KAVANAGH, 1995).

As Figuras 5.30 e 5.31, mostra a imagem com aumento de 500 vezes, alguns aspectos da tinta de $P V C$ 0\% (verniz), obtida por fratura após congelamento da amostra. A micrografia, da seção transversal, mostra a presença de vazios típicos que dão a impressão de poros de forma alongada, com elevada frequiência. A Figura 5.32, mostra o detalhe do vazio da Figura 5.30, imagem com aumento de 1500 vezes. A Figura 5.33, imagem com aumento de 250 vezes, mostra outro aspecto da tinta; pode se observar uma seção de poro, de forma alongada, dando uma noção de sua dimensão. Apenas a área central das Figuras mostra a superfície das amostras, as laterais mostram as lâminas de alumínio utilizadas no preparo dos corpos-de-prova. As saliências observadas sobre a superfície são provavelmente lascas de tinta depositadas sobre a superfície de fratura.

As Figuras 5.34 e 5.35 ilustram alguns aspectos típicos da seção transversal da amostra de tinta $P V C$ 40\%, imagem com aumento de 500 vezes, à base de resina acrílica pura, acabamento semi-brilho. Observa-se nas micrografias a presença de cristais, provavelmente dos vários tipos de pigmentos, e de pequeno número de poros rasos; não tendo sido observados poros com forma alongada como no caso da tinta de PVC 0\%. As micrografias parecem mostrar que os pigmentos existentes na tinta interromperam a formação de poros alongados na resina. A Figura 5.36, imagem com aumento de 1000 vezes, mostra a existência de microfissuras na interface pigmento/resina. 
A Figura 5.37 ilustra o aspecto típico da amostra de tinta de $P V C 60 \%$, imagem com aumento de 1000 vezes, à base de resina acrílica pura, acabamento fosco; observa-se na micrografia uma superfície bastante similar à da tinta de $P V C 40 \%$, não sendo observados poros com forma alongada, mas a presença de fissuras na interface pigmento/resina como no caso anterior.

As imagens obtidas indicam que a MEV pode ser utilizada para a determinação do $C P V C$, que hoje é estimada indiretamente pela determinação da adsorção de óleo. Os dados da microestrutura são importantes para complementar as determinações efetuadas no porosímetro de mercúrio, permitindo verificar a morfologia dos microporos não observáveis com esta última técnica.

Destes resultados pode-se dizer que as técnicas utilizadas não permitiram a obtenção de amostras suficientemente planas para análise de imagens e determinação da porosidade. A técnica por corte com micrótomo, que permite a obtenção de superfície plana, esmagou a superfície de tinta que ficou deformada pela pressão da lâmina.

Existem ultramicrótomos com maior capacidade de corte mas ainda não disponíveis na Universidade; assim, a medida da porosidade só pode ser executada após o desenvolvimento de uma técnica adequada de preparação de amostra. 


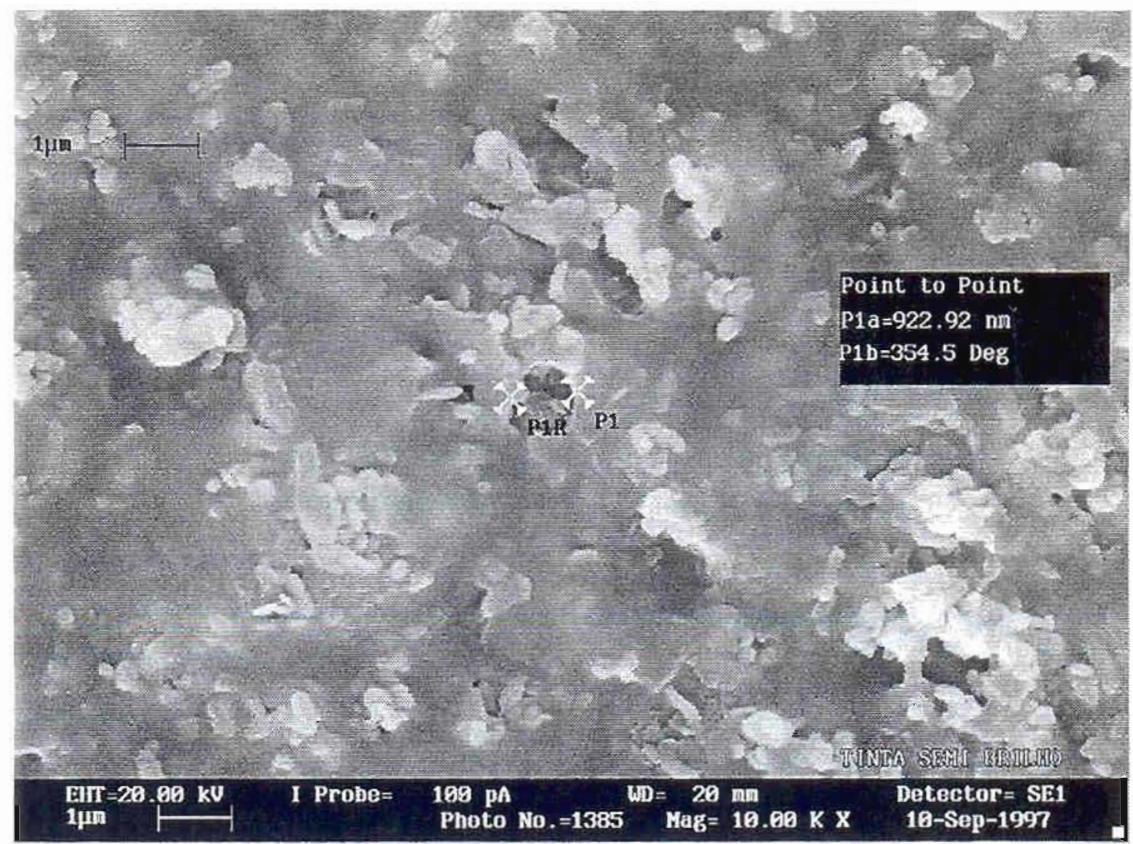

Figura 5.28: Micrografia da tinta de PVC $25 \%$, foto obtida com aumento de 10000 vezes

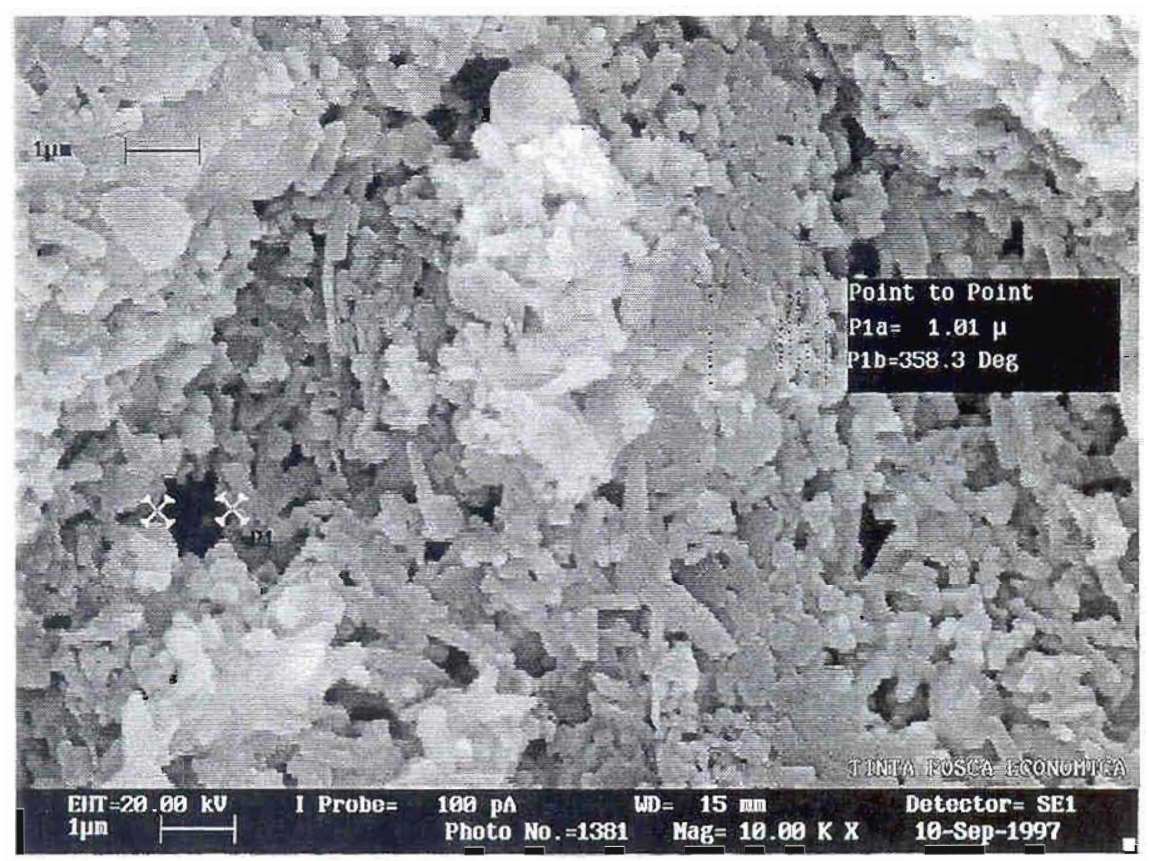

Figura 5.29: Micrografia da tinta de PVC $75 \%$, foto obtida com aumento de 10000 vezes 


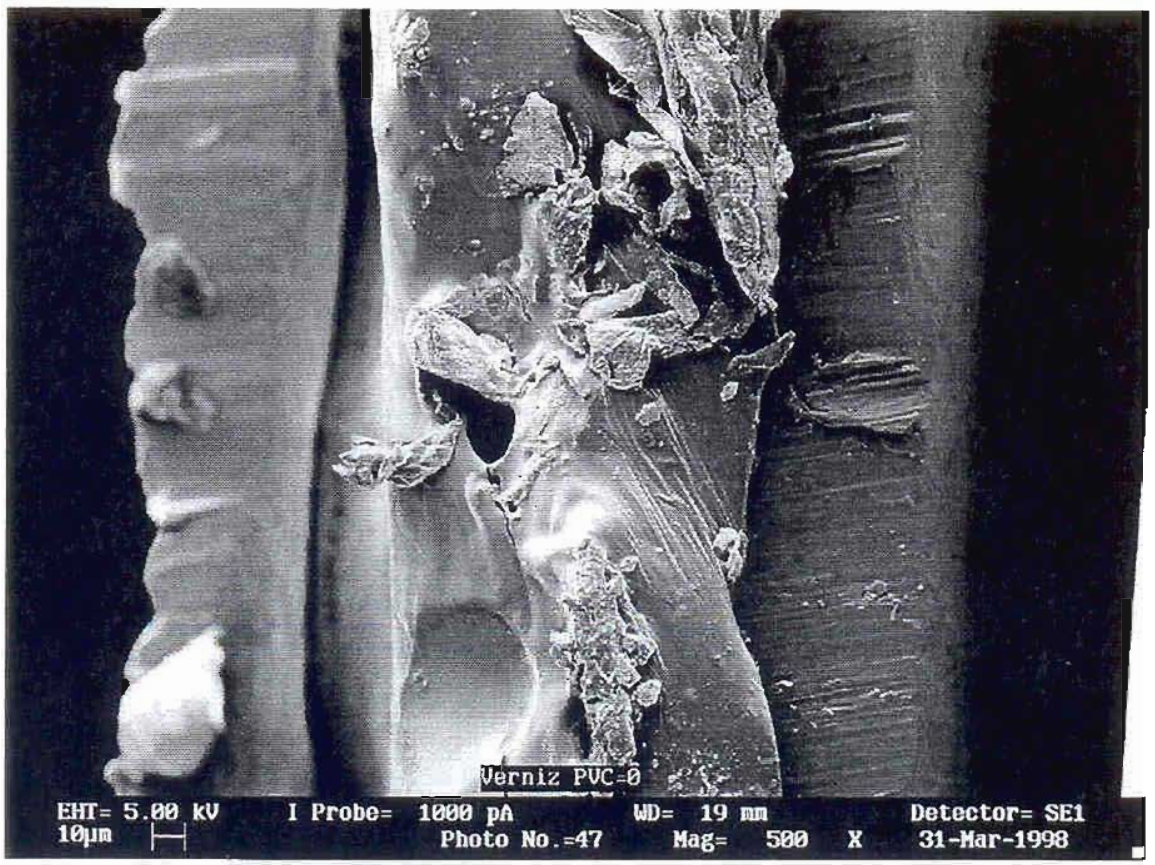

Figura 5.30: Micrografia da tinta de $P V C 0 \%$, foto obtida com aumento de 500 vezes

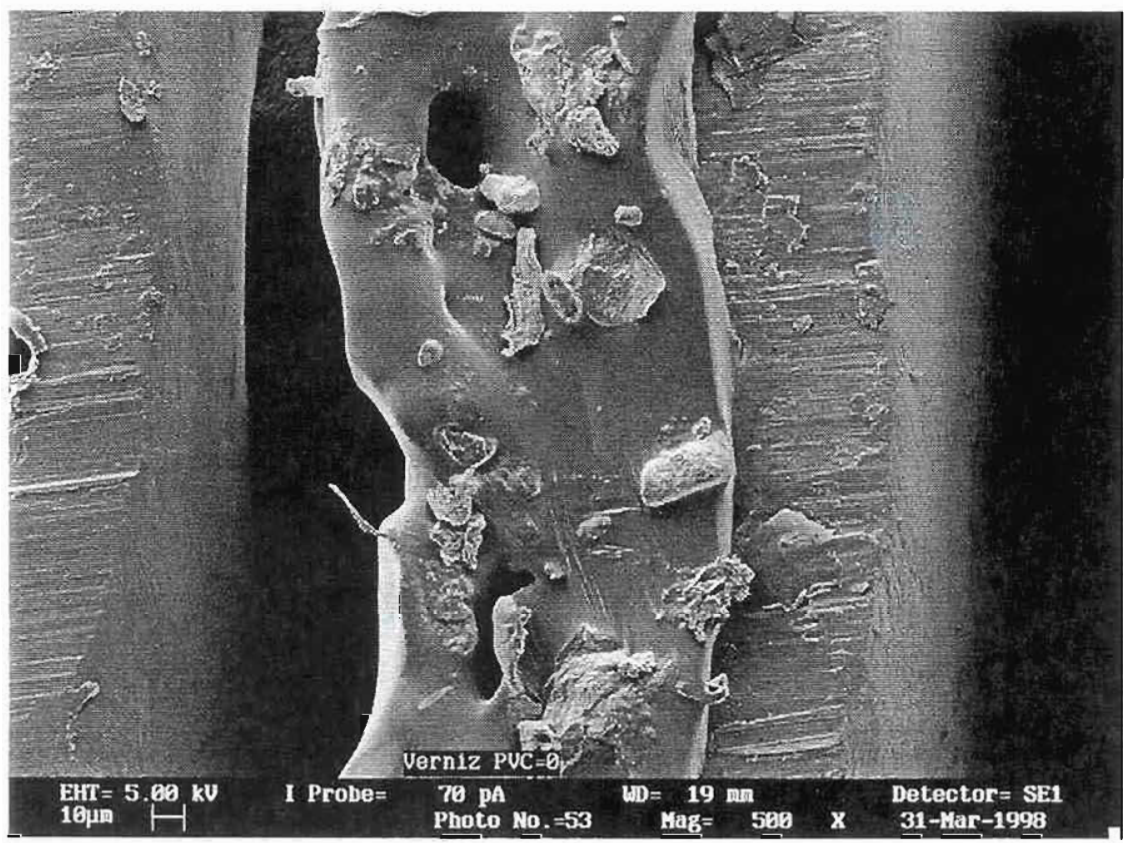

Figura 5.31: Micrografia da tinta de $P V C 0 \%$, foto obtida com aumento de 500 vezes 


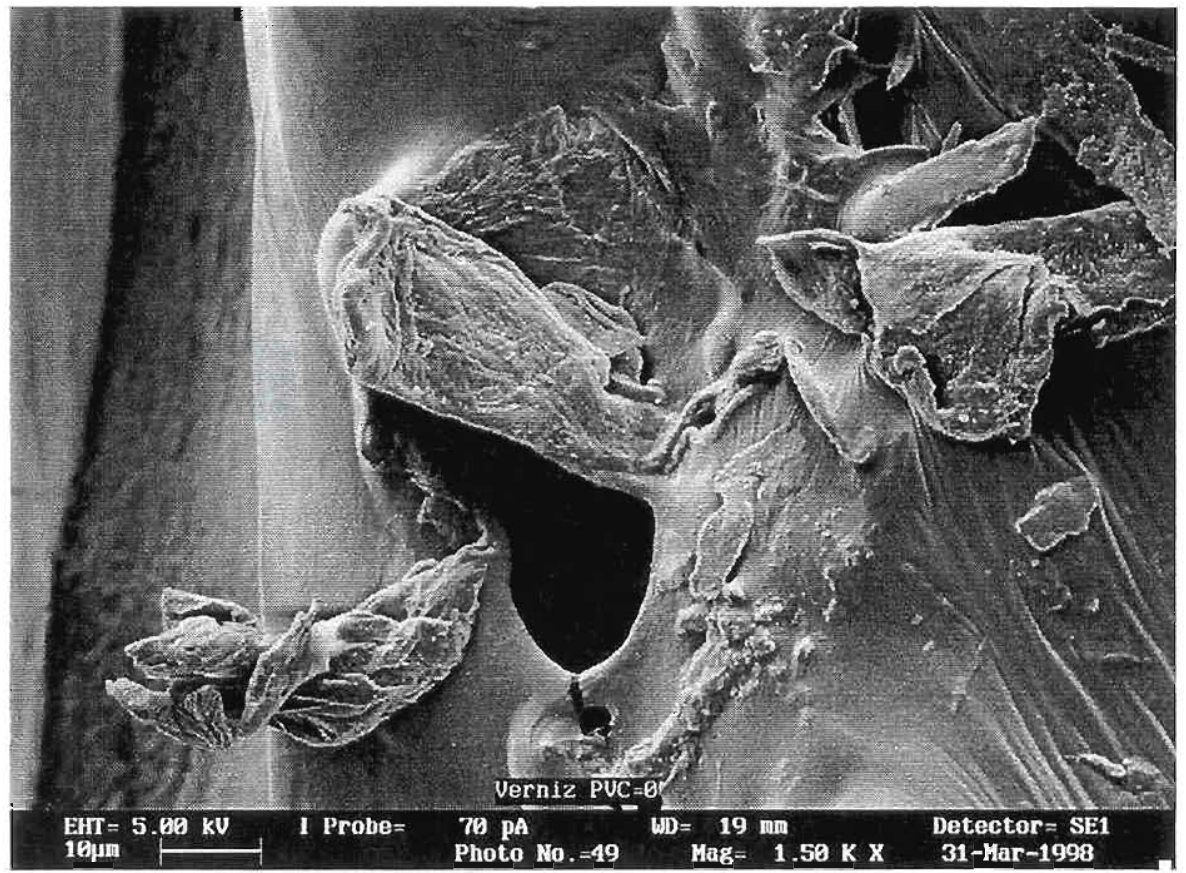

Figura 5.32: Micrografia da tinta de $P V C 0 \%$, foto obtida com aumento de 1500 vezes. Detalhe da Figura 5.31

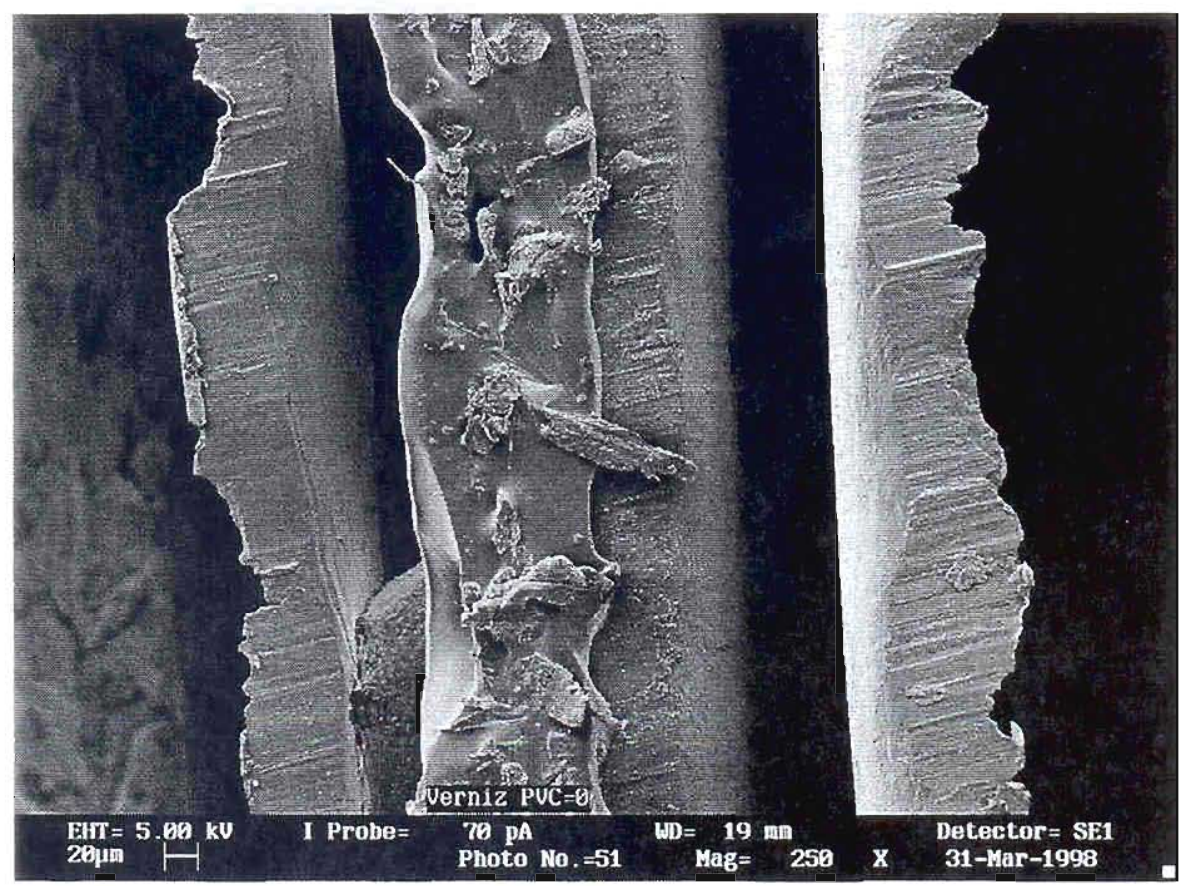

Figura 5.33: Micrografia da tinta de $P V C 0 \%$, foto obtida com aumento de 250 vezes 


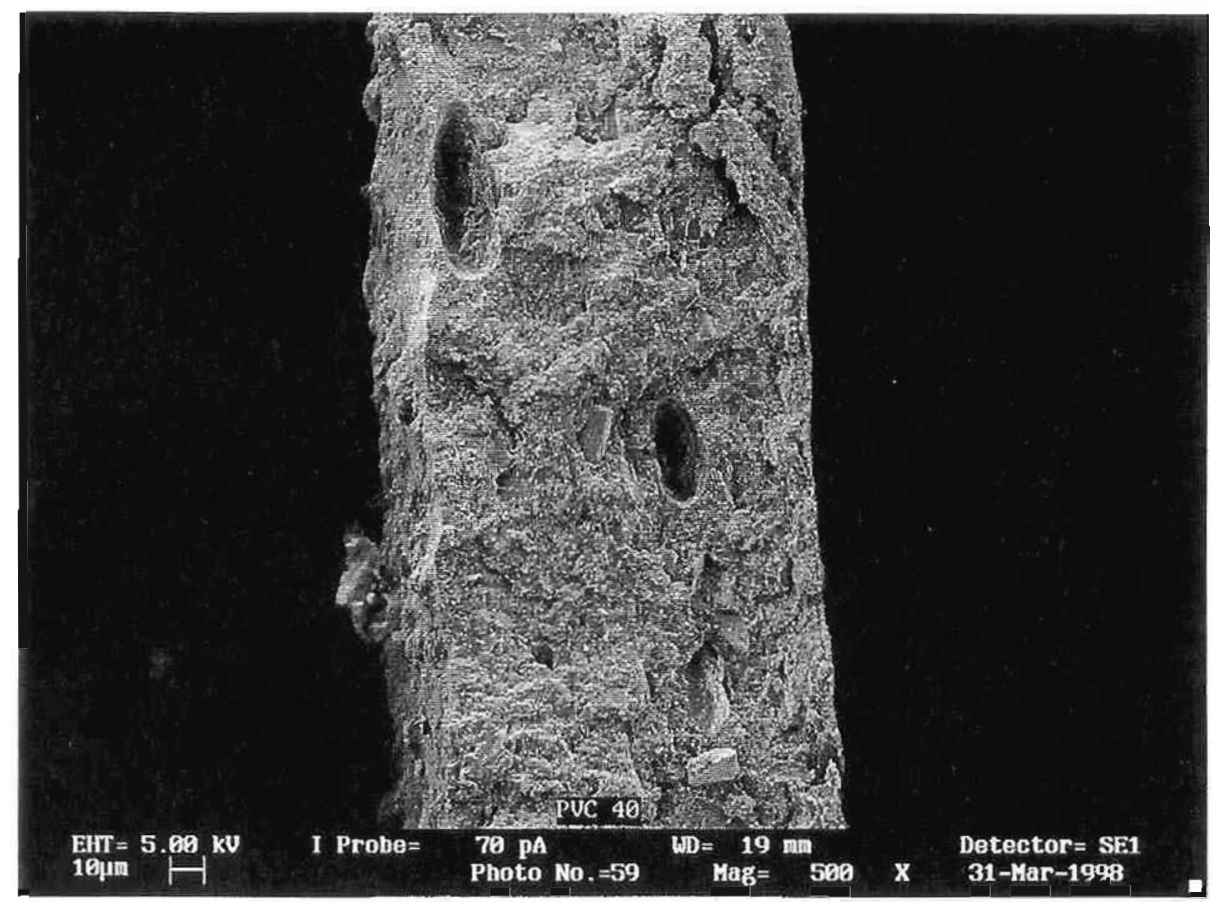

Figura 5.34: Micrografia da tinta de $P V C 40 \%$, foto obtida com aumento de 500 vexes

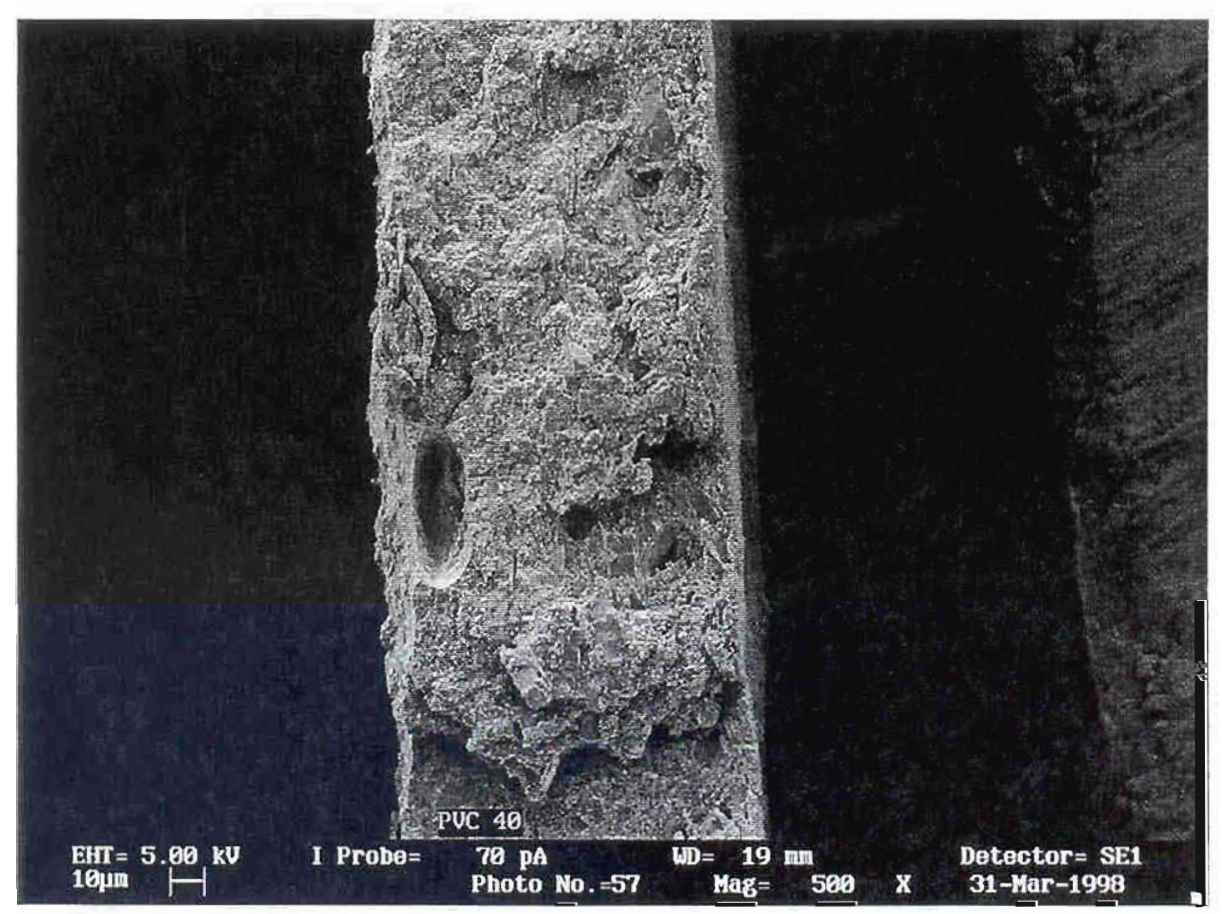

Figura 5.35: Micrografia da tinta de $P V C 40 \%$, foto obtida com aumento de 500 vezes 


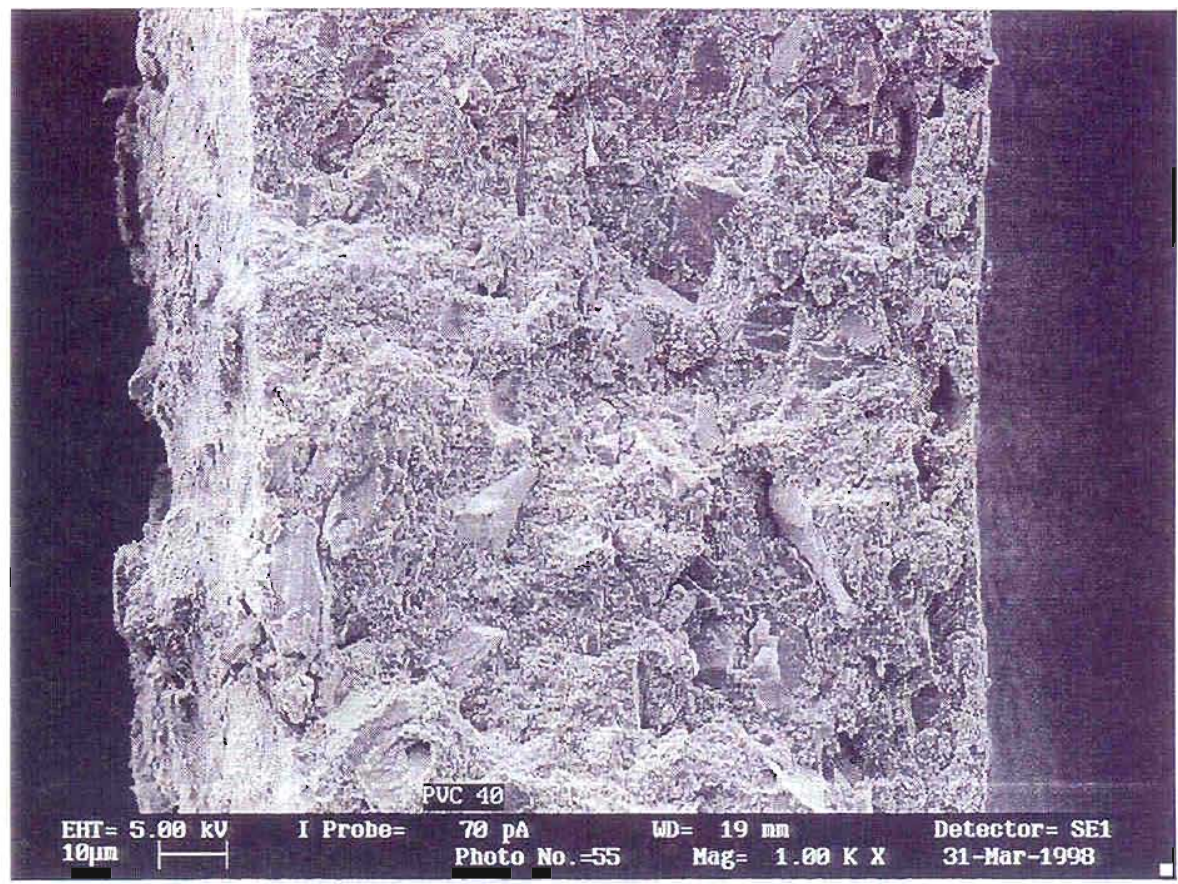

Figura 5.36: Micrografia da tinta de $P V C$. $40 \%$ analisada com 0 detector $\mathrm{SE}-1$, com aumento de 1000 vezes

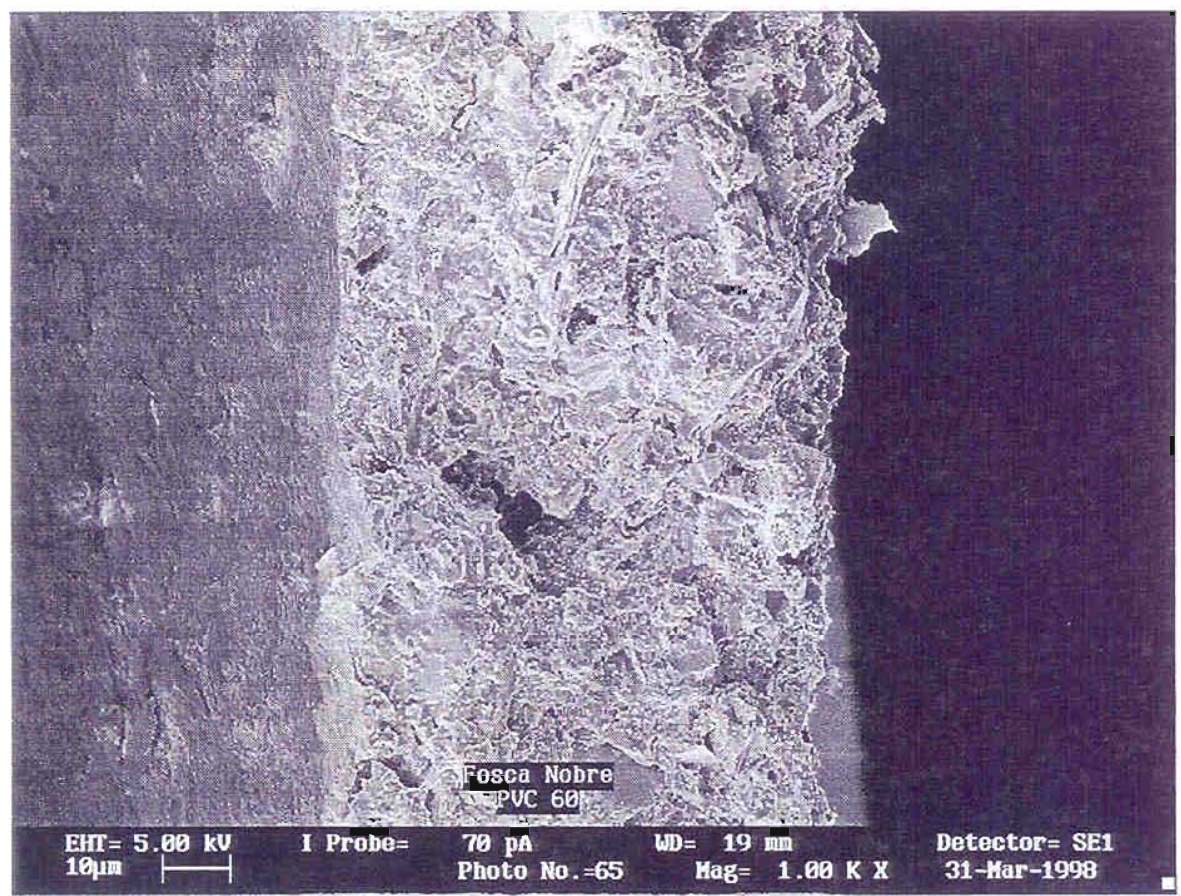

Figura 5.37: Micrografia da tinta de $P V C 60 \%$ analisada com o detector SE-1, com aumento de 1000 vezes 


\subsubsection{Determinação de porosidade de películas de tinta por intrusão de mercúrio}

Na Tabela 5.22 estão apresentados os valores de porosidade total e de poros grandes das películas de tinta, com dimensões maiores do que $0,2 \mu \mathrm{m}$, na Tabela A.VIII no ANEXO A, os valores de porosidade das tintas, e na Figura 5.38 está apresentada a distribuição do volume de poros das películas com os valores expressos em volume de mercúrio penetrado em relação à massa de tinta ensaiada $(\mathrm{mL} / \mathrm{g})$.

Tabela 5. 22 : Volume total de mercúrio penetrado

\begin{tabular}{|c|c|c|}
\hline $\begin{array}{r}\text { Tipos de tinta } \\
\text { (PVC \%) }\end{array}$ & $\begin{array}{c}\text { Porosidade total } \\
\text { (mL/g) }\end{array}$ & $\begin{array}{c}\text { Poros grandes } \\
\text { (macroporos) (mL/g) }\end{array}$ \\
\hline $\mathbf{0}$ & 1,98 & 0,50 \\
\hline $\mathbf{2 5}$ & 0,19 & 0,11 \\
\hline $\mathbf{4 0}$ & 0,18 & 0,12 \\
\hline $\mathbf{6 0}$ & 0,31 & 0,22 \\
\hline $\mathbf{7 5}$ & 0,29 & 0,25 \\
\hline
\end{tabular}

Os resultados apresentados na Tabela 5. 22 : Volume total de mercúrio penetrado mostram que as tintas de baixo $P V C$, acabamento semi-brilho, apresentam porosidade total e poros grandes, maiores do que $0,2 \mu \mathrm{m}$, de mesma ordem de grandeza, e que as tintas de alto PVC, acabamento fosco, também apresentam porosidade total e poros grandes de mesma ordem de grandeza. No caso da tinta de $P V C 0 \%$, que é o verniz, apresenta porosidade total e poros grandes bem superiores às demais tintas. 
As tintas de PVC 25\%, $40 \%$ e $60 \%$ apresentam curvas de distribuição de porosidade bastante semelhantes; primeiro, observa-se uma $\operatorname{moda}^{22}$ na faixa de poros grandes na ordem de 5 a $100 \mu \mathrm{m}$, depois, uma ausência de poros na faixa de 0,1 a $5 \mu \mathrm{m}$ e finalmente, uma moda na faixa de poros pequenos inferior a $0,1 \mu \mathrm{m}$.

Já as tintas, de PVC $0 \%$ e 75\%, apresentam curvas bem diferentes das demais; a tinta de PVC 75\% apresenta modas na faixa de poros grandes e pequenos, respectivamente, entre 5 a $100 \mu \mathrm{m}$ e inferior a $0,1 \mu \mathrm{m}$, depois uma ausência de poros na faixa de 1 a $5 \mu \mathrm{m}$ e ainda apresenta poros na faixa onde as outras tintas não apresentam, isto é, entre 0,1 a $1 \mu \mathrm{m}$. A tinta de PVC $0 \%$ apresenta poros entre $0,004 \mu \mathrm{m}$ (limite de detecção do aparelho utilizado) e pouco superior a $100 \mu \mathrm{m}$. Existe grande quantidade de poros grandes, maiores do que 7 $\mu \mathrm{m}$, e poros pequenos, menores do que $0,1 \mu \mathrm{m}$.

Esta técnica, embora seja muito utilizada para o estudo de porosidade, ela não tem sido muito usada para os estudos em tinta; os resultados obtidos, isoladamente, não são suficientes para explicar os fenomenos de transporte de massa, estes devem ser complementados com os de permeabilidade ao vapor de água, absorção de capilaridade e de MEV para explicar a influência da microestrutura nestes fenômenos.

\footnotetext{
${ }^{22}$ Maior frequência de ocorrência de poros.
} 


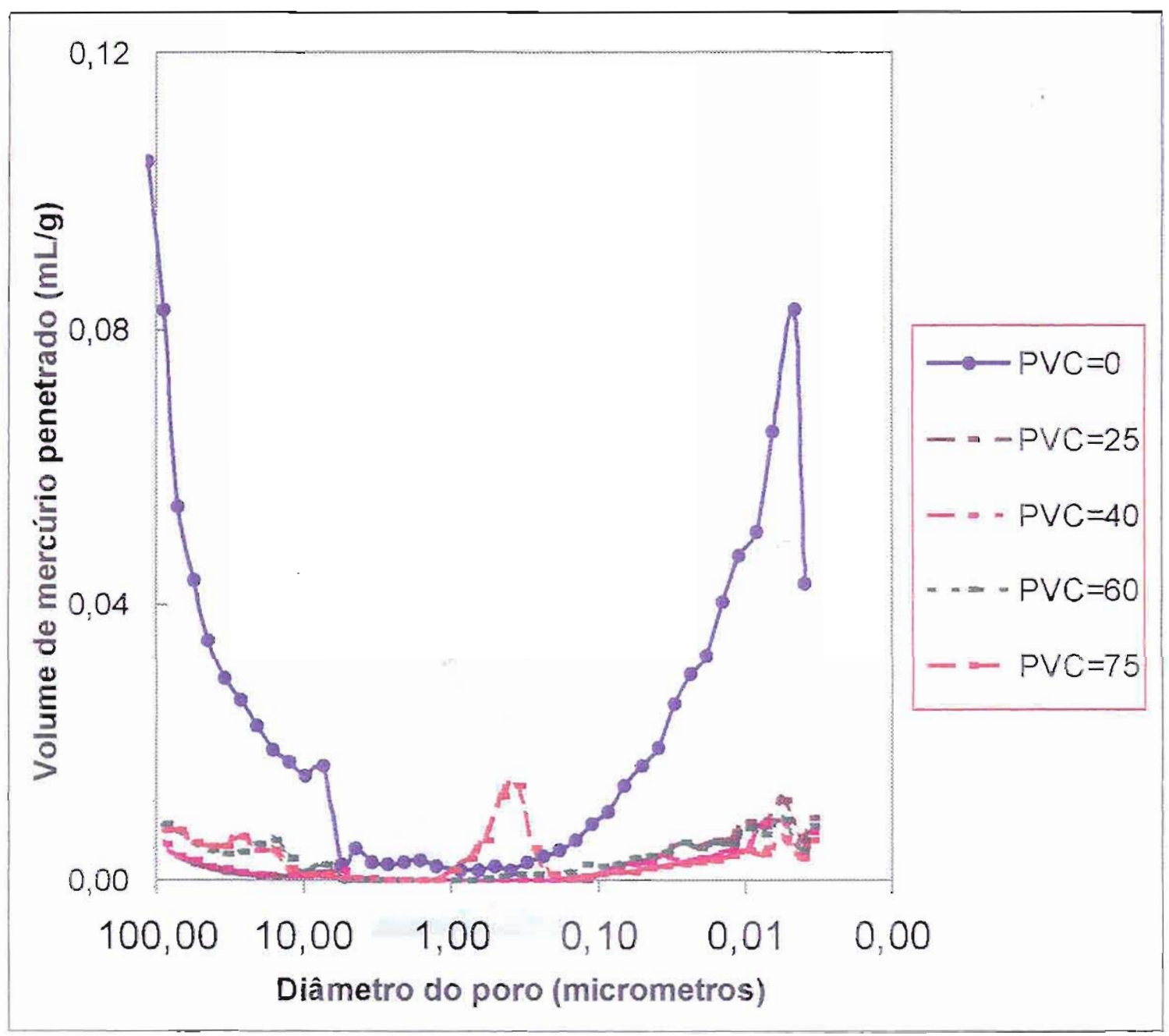

Figura 5.38: Curvas de distribuição de volume de poros nas películas de tinta 


\section{DISCUSSÃO DOS RESULTADOS}

\subsection{Introdução}

Neste Capítulo, são discutidas a influência das características da resina nas propriedades das tintas, a influência da formulação no seu desempenho como barreira de proteção, contra a penetração de água, vapor de água, anidrido carbônico $\left(\mathrm{CO}_{2}\right)$ e íon cloreto para o interior do concreto, e discutidas algumas considerações exploratórias sobre a influência da microestrutura das tintas nos fenômenos de transporte, observações estas até o momento não encontradas na literatura, bem como sobre a durabilidade das tintas.

\subsection{Características das resinas}

Os resultados obtidos nos ensaios mostraram que as características das resinas afetam de modo acentuado o desempenho das tintas. Na Tabela 6. 1 : Características das resinas estão reunidas algumas características das resinas estudadas na fase exploratória e na segunda fase.

Tabela 6. 1 : Características das resinas

\begin{tabular}{|c|c|c|c|c|}
\hline \multirow[t]{2}{*}{ Características } & \multicolumn{2}{|c|}{ fase exploratora } & \multicolumn{2}{|c|}{ Segunda fase } \\
\hline & 4acrilico puro' & estreno-acrilico & estureno acrilico & acrilico puro \\
\hline Massa mol. (nm) & 112 & 94 & 142 & 204 \\
\hline Polidispersidade & 0,10 & 0,05 & 0,06 & 0,03 \\
\hline $\mathrm{Tg}^{\circ} \mathrm{C}$ & 19,6 & 28,1 & 23,6 & 21,4 \\
\hline $\mathrm{TMFF}^{\circ} \mathrm{C}$ & $<23$ & 26 & 22 & 22 \\
\hline
\end{tabular}

A identificação da composição por comparação, em banco de espectros da biblioteca de padrões, mostrou que as 4 resinas estudadas não são provenientes de mesmos monômeros, conforme espectrogramas apresentados nas Figuras 5.1, 5.2, 5.12 e 5.13. Ambas as resinas 
da fase exploratória são copolímeros de acrílico com estireno bem como uma da segunda fase. A análise comparativa dos espectrogramas mostra picos com número de onda entre 700 e $760\left(\mathrm{~cm}^{-1}\right)$ característicos de estireno. A análise comparativa entre os espectros mostram indícios que a resina designada "acrílica pura" provavelmente possui baixo teor em estireno.

É comum no mercado, denominar "acrílico puro" copolímeros com relação $20-30 \%$ de estireno: 70-80\% de acrílico; entretanto, o aumento de oferta de acrílico puro nos últimos anos tem levado ao desaparecimento deste tipo de copolímero.

Conforme observado nos resultados de ensaios, pelo fato das resinas serem constituídas por diferentes monômeros, não apresentam o mesmo Tg; este fato levou à formulação de tintas de mesmo PVC, no entanto, com diferenças no desempenho, como pode ser observado nos resultados de ensaios de permeabilidade ao vapor e resistência à radiação solar. As tintas da fase exploratória formuladas com resina estireno-acrílico, após o envelhecimento, resultaram em películas que apresentaram amarelecimento, enquanto que, tintas formuladas com resina estireno-acrílico, designado por "acrílico puro", resultaram em películas duras e quebradiças. A diferença existente na $\mathrm{Tg}$ mostra que as resinas não apresentam o mesmo módulo de elasticidade, conforme confirmado nos resultados de envelhecimento acelerado.

Os dois tipos de tinta da fase exploratória não foram formuladas com mesmos teores de agentes coalescentes, pelo fato de serem obtidas a partir de resinas de $\mathrm{Tg}$ muito diferentes, de $19,6^{\circ} \mathrm{C}$ e de $28,1^{\circ} \mathrm{C}$. Para a formulação de tintas com TMFF ao redor de $0^{\circ} \mathrm{C}$ foi necessária a adição de diferentes tipos e teores de agentes coalescentes para a formulação das tintas de PVC $30 \%$ e 50\%. Já na segunda fase, pelo fato da $\mathrm{Tg}$ das resinas serem 
próximas, foram mantidos os mesmos tipos e teores de agentes coalescentes. Diferentes tipos de coalescentes podem resultar em películas de tintas de mesmo $P V C$, no entanto, com diferença na porosidade, o que irá influir nos fenômenos de transporte de massa.

Existe um conceito no mercado de que, tintas à base de resina estireno/acrílica possuem menor resistência à radiação solar. No entanto, os resultados de envelhecimento acelerado (exposição à UV e condensação) mostraram que as tintas obtidas com a resina estireno/acrílica da segunda fase não apresentaram significativa susceptibilidade a esta condição. Isto permite concluir que os resultados obtidos para determinada amostra de tinta são restritos a ela e que os mesmos nem sempre é possível extrapolá-los a outras tintas; a seleção de produto com base somente no tipo de resina básica nem sempre é segura, sempre havendo necessidade de realização de ensaios laboratoriais para a avaliação do seu desempenho.

A avaliação realizada com as tintaș à base de resina acrílica pura, da segunda fase, mostrou que esta realmente apresentou resistência à radiação UV superior a todas as outras estudadas.

\subsection{Propriedades de transporte de massa}

\subsubsection{Discussão sobre o mecanismo de penetração de água e vapor de água}

A influência da microestrutura nos fenômenos de transporte foi estudada com base nos resultados da determinação da porosidade por intrusão de mercúrio junto com os resultados de ensaios físicos, de determinação da permeabilidade ao vapor de água de películas de pintura e absorção de água por capilaridade no sistema concreto/pintura. Os resultados obtidos estão resumidos na Tabela 6.2 . 
Tabela 6. 2 : Dados usados na análise das propriedades de transporte de massa

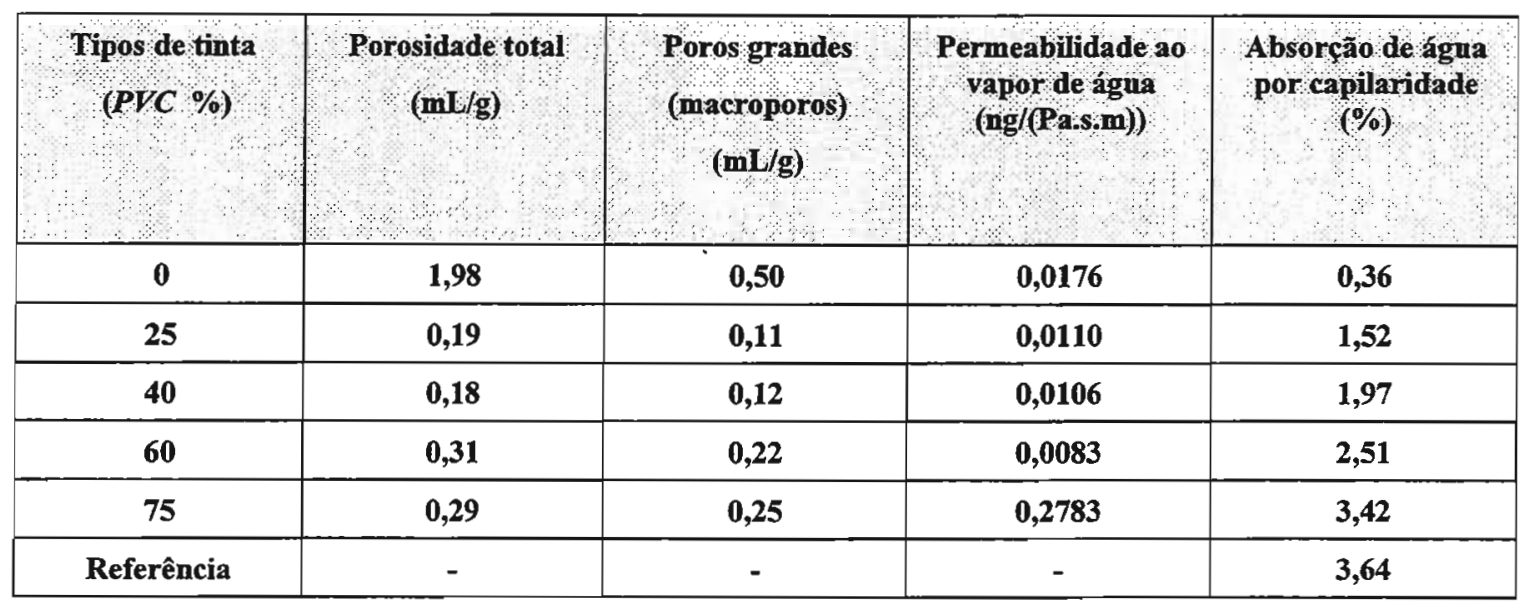

O movimento das moléculas de qualquer substância no estado sólido é bem limitado devido à força de atração; já no estado líquido, há uma redução desta força entre as moléculas, o que lhes permite maior mobilidade e é o que influi em propriedades como a tensão superficial existente nos líquidos. No estado gasoso, as forças de atração são tão fracas que as moléculas são livres, independentes e extremamente móveis. Os fluidos não têm forma e nem volume definidos e as partículas estão longe uma das outras, diferentemente do caso de sólidos. As forças de atração entre as partículas de gás são desprezíveis e, pelo fato de estarem livres e em temperaturas mais elevadas possuem maior energia cinética; como resultado fluem em todas as direções (ADDLESON, 1972).

Os vapores apresentam o mesmo comportamento dos gases. Os gases e o vapor de água passam por poros grandes e pequenos. A ausência de tensão superficial e sua reduzida viscosidade nos gases e no vapor de água permitem sua passagem através de poros pequenos, enquanto que a água líquida, devido à tensão superficial, só consegue passar através de poros grandes. A água no estado líquido tem suas moléculas ligadas uma às 
outras através de forças de van der Waals, devido à formação de pontes de hidrogênio entre as moléculas.

Os dados de porosidade mostram que a tinta de $P V C 0 \%$ possui poros grandes e pequenos; assim, ela é muito mais permeável a gases e ao vapor de água do que as tintas de $P V C 25 \%$, $40 \%$ e $60 \%$, conforme mostrado pelos resultados de ensaio de permeabilidade, com exceção da tinta de PVC $75 \%$.

A observação da sua microestrutura por meio de MEV (Figuras 5.31 e 5.32) mostra que esta tinta realmente possui grande quantidade de poros grandes. Entretanto, os resultados obtidos nos ensaios físicos mostram que ela apresenta baixa absorção de água por capilaridade, isto é, não permite a passagem de água líquida. Estes resultados levam a crer que os poros determinados na porosimetria $(0,50 \mathrm{~mL} / \mathrm{g})$, com dimensões maiores do que 0,2 $\mu \mathrm{m}$, e observados por MEV são poros grandes e, provavelmente, a maioria são do tipo “fechado" ${ }^{23}$, não passante. O transporte de massa ocorre na forma de vapor de água, através dos poros pequenos, que são passantes, e na forma de líquidos por poucos poros grandes passantes, os quais foram determinados pelo ensaio de permeabilidade ao vapor de água e absorção de água por capilaridade. Os poros não passantes são definidos pela BS 7591: Part 4: 1993 como sendo “cegos". Os poros pequenos devem ser aqueles resultantes do volume livre, isto é, da fração não ocupada da estrutura do polímero. Este volume geralmente é pequeno em temperaturas abaixo da $\mathrm{Tg}$, e aumenta com a elevação da temperatura. A "porosidade cega" observada nesta tinta deve ter sido formada durante o processo de coalescência, no processo de secagem da tinta.

\footnotetext{
${ }^{23}$ No trabalho poro "fechado" significa de difícil acesso à água no estado líquido.
} 
A permeabilidade ao vapor de água depende da porosidade total, dos grandes e dos pequenos. A tinta de $P V C 75 \%$, apesar de apresentar maior valor de poros grandes do que a tinta de PVC 0\%, possui elevada permeabilidade ao vapor de água, de 0,2783 ng/(Pa.s.m), e elevada absorção de água por capilaridade. Os resultados levam a crer que os poros determinados na porosimetria são suficientemente grandes e que são do tipo passante permitindo a passagem de água líquida e vapor.

As micrografias ( Figưras 5.33 e 5.34) obtidas parecem mostrar que os poros "cegos" de forma alongada, observados na tinta de PVC 0\%, foram interrompidos pela adição dos pigmentos nas tintas. A porosidade cega desta tinta com a adição de pigmentos tornou-se passante e quanto maior o teor de pigmento maior é a porosidade passante, conforme mostrado pelos resultados de absorção de água por capilaridade.

Nas tintas, a resina que envolve as partículas de pigmento se deforma, durante o processo de formação de filme. Se a resina (polímero) é muito rígida ela não consegue se deformar suficientemente de modo a formar um filme isento de poros e, como resultado formam fissuras na interface pigmento/resina. Nas Figuras 5.37 e 5.38 pode-se observar a presença de fissuras na interface pigmento/resina nas tintas de $P V C 40 \%$ e $60 \%$, resultando em absorção de água por capilaridade. Em sendo o $P V C$ acima do crítico, é comum ocorrer aglomerados de pigmentos em que a resina não consegue penetrar, ficando um espaço vazio que é o poro (DINIZ, F. D.; GNECCO, C., 1993), por onde pode passar a água líquida como no caso da tinta de PVC 75\%; a Figura 6. 1 ilustra o ponto onde há uma mudança radical da permeabilidade ao vapor de água, que é o ponto do $P V C$ crítico. 


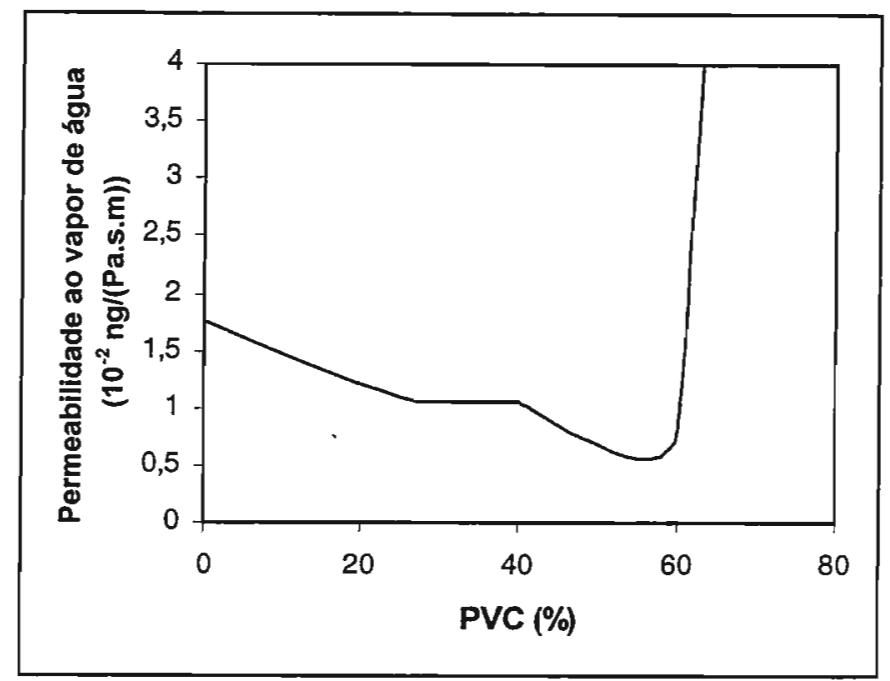

Figura 6. 1 : Influência do PVC das tintas na permeabilidade ao vapor de água

\subsubsection{Discussão sobre o processo de penetração de agentes agressivos}

De modo geral, as tintas protegem contra a penetração de agentes agressivos e, em concretos pobres, o grau de proteção varia em função da composição, com exceção da tinta de $P V C$ 75\%. Quanto maior o teor de resina, menor o $P V C$ e maior a proteção. Provavelmente, na tinta de $P V C 75 \%$ a relação pigmento/resina está abaixo da crítica e assim existem regiões de aglomerados de pigmento sem resina, ficando um vazio por onde os agentes entram e saem facilmente (vide Figura 5.28). Por isso, a permeabilidade ao vapor, a absorção e evaporação de água, penetração do íon cloreto e $\mathrm{CO}_{2}$ é elevada.

Nas tintas de $P V C 25 \%, 40 \%$ e $60 \%$ os poros de resina que permitiam a entrada e saída de vapor de água são interrompidos pela presença dos pigmentos e então a entrada da água com e sem cloreto se dá através das fissuras existentes na interface pigmento e resina.

Os resultados de penetração de $\mathrm{CO}_{2}$ não foram correlacionados com a permeabilidade ao vapor de água e nem por porosimetria pelo fato de ter sido usado um procedimento de 
ensaio que não permitiu uma diferenciação nítida de comportamento entre as tintas. $\mathrm{Na}$ condição em que foi realizado o ensaio de carbonatação acelerada observou-se que as tintas de $P V C 75 \%$ e de $60 \%$ permitiram a penetração do $\mathrm{CO}_{2}$ porém, não foi observada uma diferenciação nítida no comportamento entre eles e as tintas de $P V C 0 \%, 25 \%$, e $40 \%$ não apresentaram penetração do $\mathrm{CO}_{2}$. O procedimento usado deve ser revisto alterando-se as condições de ensaio como: tempo de exposição, concentração de $\mathrm{CO}_{2}$, dimensão da brita usada no preparo dos corpos-de-prova e dimensão do próprio corpo-de-prova.

\subsubsection{Influência do substrato}

Os ensaios de desempenho realizados em concreto de fck=20 MPa e de $40 \mathrm{MPa}$ mostram que as características do substrato tem grande influência nos fenômenos de transporte de massa. $\mathrm{O}$ ensaios de absorção de água, penetração de íon cloreto e $\mathrm{CO}_{2}$ mostraram que concretos ricos por si só já apresentam baixa penetração a estes agentes. A aplicação de tinta em concreto rico pode ser considerado predominantemente decorativo e não de proteção.

\subsection{Durabilidade das tintas}

Os resultados obtidos até o momento permitem tecer algumas considerações preliminares quanto ao desempenho das tintas formuladas com resina acrílica pura como segue:

Os ensaios realizados em película mostraram a viabilidade de uso desta resina na formulação de tintas para a proteção contra a penetração de água, vapor de água, íon cloreto e $\mathrm{CO}_{2}$.

Os ensaios de desempenho foram realizados em concretos recém-tratados e as considerações efetuadas com base nestes resultados; entretanto, como as tintas são produtos 
que se degradam ao longo do tempo, os ensaios devem ser novamente realizados com as tintas aplicadas nos painéis de concreto, e expostos na Estação de Envelhecimento Natural (EEN), levando em conta a variável tempo.

Os ensaios realizados até o momento são de envelhecimento acelerado em laboratório, estes apenas reproduzem de modo simulado condições específicas pré estabelecidas e não uma condição de exposição real; os resultados são sempre comparativos em relação a uma amostra de desempenho conhecido. $\mathrm{Na}$ exposição em EEN, os corpos-de-prova são expostos à ação de todos os agentes agressivos simultaneamente, os quais resultam em efeitos sinérgicos não reprodutíveis em laboratório.

Tanto os ensaios de envelhecimento acelerado como o natural é de elevada importância nos estudos de durabilidade das tintas. A não realização desses ensaios pode levar a conclusões errôneas como por exemplo, o desempenho favorável da tinta de PVC 0\%, isto é, do verniz quanto aos fenômenos de transporte de massa. A ausência de pigmentos nesta tinta, principalmente do dióxido de titânio, leva a uma menor durabilidade comparativamente às outras tintas assim, apesar desta tinta, quando recém aplicada, apresentar maior resistência à penetração de agentes agressivos ela pode apresentar desempenho inferior após alguns anos de exposição ao intemperismo. 


\section{CONCLUSÕES E CONSIDERAÇÕES FINAIS}

\subsection{Propostas de continuação do estudo}

A revisão bibliográfica realizada mostrou que a nível internacional estavam sendo estudadas tintas acrílicas à base de polímeros elastoméricos, inclusive em mistura com cimento e agregado miúdo (COPPOLA et al, 1997). Na época do início do estudo (1996) ainda não era comum no mercado brasileiro a existência de polímeros acrílicos elastoméricos de $\mathrm{Tg}<0$; a comercialização de tintas acrílicas elastoméricas é bem recente, iniciada apenas em 1997. Naquela época, pretendia-se estudar tintas acrílicas elastoméricas, no entanto, não se conseguiu, junto aos fabricantes, apoio à formulação de tintas com este tipo de resina; os fabricantes que possuíam este tipo de resina não estavam interessados neste tipo de estudo. Pelo fato do objetivo principal do estudo era demonstrar que com uma formulação adequada as tintas podem ser utilizadas como barreira de proteção eficiente contra a penetração de agentes agressivos, o estudo foi iniciado com resina acrílica sem características elastoméricas.

Apesar dos problemas havidos, o estudo atingiu os objetivos, pois os resultados mostram a importância da formulação das tintas nas suas propriedades. Dada a importância das tintas na proteção de fachadas de edifícios há necessidade de continuar estudos nesta linha de pesquisa, ressaltando-se os seguintes pontos:

- continuar o estudo de envelhecimento natural por meio de ensaios nos corpos-de-prova expostos em EEN;

- estudar comparativamente as tintas à base de resinas acrílicas com $\mathrm{Tg}$ de $30^{\circ} \mathrm{C}, 20^{\circ} \mathrm{C} \mathrm{e}$ inferior a $0^{\circ} \mathrm{C}$, com formulações preparadas em laboratório; 
- verificar a validade das considerações exploratórias sobre a influência da microestrutura das tintas nos fenômenos de transporte, já que até o momento não foram encontrados na literatura estudos nesta linha de pesquisa;

- estudar o mecanismo de evaporação: O processo de secagem é um fenômeno complexo onde estão envolvidos vários fatores; dada a sua importância na durabilidade das tintas este fenômeno deve ser melhor estudado;

- desenvolver novas técnicas de estudo do envelhecimento natural. Por exemplo, pelo fato da umidade ser um fator de elevada importância na durabilidade das tintas é extremamente importante o desenvolvimento de técnicas de registro e de medida da umidade superficial (time-of-wetness) em pinturas expostas em ambiente de umidade elevada. A nível internacional, no momento esta técnica é uma das mais utilizadas para o estudo dos mecanismos de degradação dos materiais.

\subsection{Transferência de resultados ao meio técnico}

Os conhecimentos adquiridos nesta pesquisa estão sendo divulgados ao meio técnico através de apresentação de trabalhos em congressos, seminários e simpósios nacionais e internacionais, desde 1995. Foram publicados 2 trabalhos no IBRACON (1995) e dois trabalhos no ENTAC (1995) e encontram-se em publicação (no prelo) dois trabalhos no exterior.

Após a apresentação da tese pretende-se divulgar os resultados em publicações periódicas na área de: engenharia civil, polímeros e tintas, revistas de microscopia eletrônica. 


\subsection{Conclusões}

\subsubsection{Quanto aos resultados obtidos}

Pode se concluir que o desempenho das tintas acrílicas varia em função da formulação, isto é, do tipo de resina acrílica, do teor ótimo de pigmento etc. As pinturas obtidas com tintas de elevado $P V C 60 \%$ e $75 \%$, acabamento fosco (teor de resina menor ou igual a $11 \%$ ), não protegem o concreto contra a penetração de água por capilaridade, íon cloreto ou o $\mathrm{CO}_{2}$, sendo considerado predominantemente decorativo e não de proteção. A proteção pode ser obtida pela aplicação de tinta de baixo $P V C$, acabamento semibrilho, e em caso de necessidade de uso de acabamento fosco aplicar como $1^{\mathrm{a}}$ demão a tinta semi-brilho e nas outra demãos o acabamento fosco. Na Tabela 7.1 estão resumidas as características das tintas.

Tabela 7.1: Propriedades das tintas

\begin{tabular}{|c|c|}
\hline Tipos de tinta & Propriedades das tintas \\
\hline Acabamento fosco & Decorativa \\
$(P V C 60 \%$ e $75 \%)$ & \\
\hline Acabamento semi-brilho & Barreira de proteção contra agentes agressivos \\
$(P V C 40 \%$ e $25 \%)$ & \\
\hline
\end{tabular}

Os resultados obtidos referem-se apenas a produtos recém aplicados e conforme já discutido, a durabilidade destes produtos é de elevada importância nos fenômenos de transporte de massa devendo ser reavaliados após envelhecimento em EEN. 


\subsubsection{Quanto ao estudo realizado}

Os resultados obtidos atenderam os objetivos propostos como de:

- alertar o meio técnico quanto à importância da formulação na proteção contra a penetração de agentes agressivos em substratos porosos de fachadas de edificios;

- fornecer subsídios para a especificação de requisitos e critérios de qualidade de tiṇtas de proteção;

- estudar a influência da microestrutura das tintas nos fenômenos de transporte de massa.

Conforme HELENE ( 1993), “o reparo e a manutenção de edificações construídas e de obras de infraestrutura no país como pontes, viadutos e túneis é uma realidade cada vez mais presente na área de engenharia civil brasileira e que tende a agravar-se nos próximos anos". Assim, a conscientização do meio técnico quanto aos critérios de seleção de produtos e conceitos de projeto é de elevada importância. 
ANEXO A 
ANEXOS

Tabela A.I: Resultados individuais da alteração de brilho após envelhecimento acelerado (Estudo exploratório)

\begin{tabular}{|c|c|c|c|c|}
\hline \multirow[t]{2}{*}{ Tipo de resina } & \multirow{2}{*}{$\begin{array}{l}P V C \\
(\%)\end{array}$} & \multirow{2}{*}{$\begin{array}{c}\text { Sem } \\
\text { envelhecimento }\end{array}$} & \multicolumn{2}{|c|}{ Após envelhecimento } \\
\hline & & & $300 \mathrm{~h}$ & $600 h$ \\
\hline \multirow[b]{2}{*}{ Acrílica pura } & 50 & $\begin{array}{c}2,7 \\
2,5 \\
2,6 \\
3,1 \\
3,0 \\
-\end{array}$ & $\begin{array}{l}2,6 \\
2,1 \\
2,7 \\
2,4 \\
2,7 \\
1,7\end{array}$ & $\begin{array}{l}2,5 \\
1,6 \\
2,4 \\
2,5 \\
2,7 \\
2,2\end{array}$ \\
\hline & 30 & $\begin{array}{l}23,3 \\
21,9 \\
25,5 \\
22,9 \\
22,5 \\
25,3 \\
\end{array}$ & $\begin{array}{c}9,3 \\
11,1 \\
5,0 \\
7,3 \\
7,0 \\
7,0 \\
\end{array}$ & $\begin{array}{c}9,7 \\
11,1 \\
9,5 \\
7,3 \\
7,7 \\
12,0 \\
\end{array}$ \\
\hline \multirow{5}{*}{ Estireno/acrílico } & 50 & $\begin{array}{l}2,6 \\
2,6 \\
2,6 \\
2,6 \\
2,6 \\
2,6 \\
\end{array}$ & $\begin{array}{l}1,6 \\
1,6 \\
2,2 \\
2,2 \\
2,1 \\
2,2 \\
\end{array}$ & $\begin{array}{l}2,3 \\
2,4 \\
2,3 \\
2,2 \\
2,2 \\
2,0 \\
\end{array}$ \\
\hline & 30 & $\begin{array}{l}27,0 \\
26,4 \\
25,3 \\
26,2 \\
27,5 \\
27,2 \\
\end{array}$ & $\begin{array}{l}5,4 \\
7,5 \\
6,2 \\
6,0 \\
6,9 \\
8,6 \\
\end{array}$ & $\begin{array}{l}3,7 \\
4,9 \\
3,7 \\
3,9 \\
3,2 \\
5,4 \\
\end{array}$ \\
\hline & 20 & $\begin{array}{l}33,7 \\
38,8 \\
39,4 \\
37,6 \\
38,3 \\
39,2 \\
\end{array}$ & $\begin{array}{c}9,9 \\
11,3 \\
7,0 \\
8,8 \\
11,7 \\
8,1 \\
\end{array}$ & $\begin{array}{l}6,3 \\
6,8 \\
8,4 \\
5,6 \\
8,6 \\
9,1 \\
\end{array}$ \\
\hline & 10 & $\begin{array}{l}42,7 \\
50,1 \\
43,3 \\
47,3 \\
52,3 \\
48,7 \\
\end{array}$ & $\begin{array}{l}4,7 \\
6,2 \\
4,5 \\
6,6 \\
7,7 \\
6,1 \\
\end{array}$ & $\begin{array}{l}4,2 \\
5,2 \\
6,1 \\
4,8 \\
5,1 \\
5,0 \\
\end{array}$ \\
\hline & $\mathbf{0}$ & $\begin{array}{l}74,6 \\
66,5 \\
70,2 \\
74,9 \\
65,9 \\
74,1\end{array}$ & $\begin{array}{c}9,9 \\
11,5 \\
6,6 \\
9,3 \\
15,0 \\
13,4 \\
\end{array}$ & $\begin{array}{l}4,9 \\
6,6 \\
4,7 \\
3,9 \\
3,2 \\
3,7 \\
\end{array}$ \\
\hline
\end{tabular}


Tabela A.II: Resultados individuais da avaliação colorimétrica instrumental computadorizada (Primeira fase: exploratório)

\begin{tabular}{|c|c|c|c|c|c|}
\hline \multirow[t]{2}{*}{ Tipo de resina } & \multirow{2}{*}{$\begin{array}{l}P V C \\
(\%)\end{array}$} & \multicolumn{2}{|c|}{ Após 300 h } & \multicolumn{2}{|c|}{ Após 600 h } \\
\hline & & $\begin{array}{l}\text { Alteração } \\
\text { de cor }\end{array}$ & $\begin{array}{l}\text { Indice de } \\
\text { amarelecimento }\end{array}$ & $\begin{array}{l}\text { Alteração } \\
\text { de cor }\end{array}$ & $\begin{array}{c}\text { Indice de } \\
\text { amarelecimento }\end{array}$ \\
\hline \multirow{8}{*}{ Acrílica pura } & \multirow{4}{*}{50} & 0,62 & 0,73 & 0,72 & 0,46 \\
\hline & & 0,60 & 0,52 & 0,69 & 0,48 \\
\hline & & 0,61 & 0,39 & 0,66 & 0,49 \\
\hline & & 0,66 & 0,45 & 0,62 & 0,49 \\
\hline & \multirow{4}{*}{30} & 0,69 & 1,00 & 0,76 & 0,96 \\
\hline & & 0,68 & 0,98 & 0,74 & 0,90 \\
\hline & & 0,61 & 1,02 & 0,77 & 0,88 \\
\hline & & 0,72 & 1,03 & 0,79 & 0,88 \\
\hline \multirow{20}{*}{ Estireno/acrílico } & \multirow{4}{*}{50} & 1,42 & 2,02 & 1,31 & 1,88 \\
\hline & & 1,47 & 2,10 & 1,30 & 1,81 \\
\hline & & 1,44 & 2,08 & 1,29 & 1,79 \\
\hline & & 1,41 & 2,03 & 1,26 & 1,74 \\
\hline & \multirow{4}{*}{30} & 1,51 & 2,24 & 1,46 & 2,14 \\
\hline & & 1,50 & 2,22 & 1,46 & 2,12 \\
\hline & & 1,47 & 2,18 & 1,43 & 2,07 \\
\hline & & 1,48 & 2,19 & 1,43 & 2,04 \\
\hline & \multirow{4}{*}{20} & 2,70 & 3,96 & 2,38 & 3,52 \\
\hline & & 2,45 & 3,62 & 2,29 & 3,37 \\
\hline & & 2,36 & 3,49 & 2,21 & 3,25 \\
\hline & & 2,47 & 3,65 & 2,16 & 3,18 \\
\hline & \multirow{4}{*}{10} & 4,71 & 6,92 & 4,08 & 6,01 \\
\hline & & 4,04 & 5,94 & 3,98 & 5,87 \\
\hline & & 3,81 & 5,61 & 3,88 & 5,71 \\
\hline & & 4,24 & 6,25 & 3,79 & 5,58 \\
\hline & \multirow{4}{*}{ 0 } & 15,12 & 22,56 & 19,30 & 28,25 \\
\hline & & 14,98 & 22,44 & 19,30 & 28,25 \\
\hline & & 15,20 & 22,73 & 18,81 & 27,44 \\
\hline & & 15,02 & 22,36 & 19,54 & 28,47 \\
\hline
\end{tabular}


Tabela A.III: Resultados individuais da alteração de brilho após envelhecimento acelerado ( Segunda fase: Formulação estudada) - (continua)

\begin{tabular}{|c|c|c|c|c|}
\hline \multirow[t]{2}{*}{ Tipo de resina } & \multirow{2}{*}{$\begin{array}{l}P V C \\
(\%) \\
\end{array}$} & \multirow{2}{*}{$\begin{array}{c}\text { Sem } \\
\text { envelhecimento }\end{array}$} & \multicolumn{2}{|c|}{ Após envelhecimento } \\
\hline & & & $300 \mathrm{~h}$ & $600 \mathrm{~h}$ \\
\hline \multirow{24}{*}{ Estireno-acrílico } & \multirow{6}{*}{75} & 2,2 & 2,1 & 2,3 \\
\hline & & 2,3 & 2,1 & 2,4 \\
\hline & & 2,2 & 2,2 & 2,4 \\
\hline & & 2,2 & 2,3 & 2,4 \\
\hline & & $2, \dot{3}$ & 2,3 & 2,2 \\
\hline & & 2,2 & 2,3 & 2,0 \\
\hline & \multirow{6}{*}{60} & 2,0 & 2,0 & 2,1 \\
\hline & & 2,0 & 2,0 & 2,1 \\
\hline & & 2,1 & 2,0 & 2,1 \\
\hline & & 2,0 & 2,0 & 2,1 \\
\hline & & 2,0 & 2,0 & 2,1 \\
\hline & & 2,0 & 2,0 & 2,1 \\
\hline & \multirow{6}{*}{25} & 29,1 & 14,5 & 10,5 \\
\hline & & 31,1 & 12,3 & 10,7 \\
\hline & & 29,9 & 12,3 & 12,7 \\
\hline & & 28,0 & 15,3 & 10,6 \\
\hline & & 32,8 & 15,9 & 10,7 \\
\hline & & 29,5 & 16,5 & 10,6 \\
\hline & \multirow{6}{*}{0} & 128,6 & 90,5 & - \\
\hline & & 111,1 & 87,8 & - \\
\hline & & 116,8 & 78,5 & - \\
\hline & & 116,8 & 86,6 & - \\
\hline & & 120,5 & 95,9 & - \\
\hline & & 122,5 & 97,6 & - \\
\hline
\end{tabular}


Tabela A.III: Resultados individuais da alteração de brilho após envelhecimento acelerado ( Segunda fase: Formulação estudada) - (continuação)

\begin{tabular}{|c|c|c|c|c|}
\hline \multirow[t]{2}{*}{ Tipo de resina } & \multirow{2}{*}{$\begin{array}{r}P V C \\
(\%) \\
\end{array}$} & \multirow{2}{*}{$\begin{array}{c}\text { Sem } \\
\text { envelhecimento } \\
\end{array}$} & \multicolumn{2}{|c|}{ Após envelhecimento } \\
\hline & & & $300 \mathrm{~h}$ & $600 \mathrm{~h}$ \\
\hline \multirow{5}{*}{ Acrílico-puro } & 75 & $\begin{array}{l}2,3 \\
2,3 \\
2,3 \\
2,5 \\
2,5 \\
2,4 \\
\end{array}$ & $\begin{array}{l}1,9 \\
2,2 \\
2,2 \\
2,3 \\
2,2 \\
2,3 \\
\end{array}$ & $\begin{array}{l}2,2 \\
2,2 \\
2,2 \\
2,2 \\
2,2 \\
2,2 \\
\end{array}$ \\
\hline & 60 & $\begin{array}{l}2,2 \\
2,2 \\
2,2 \\
2,1 \\
2,1 \\
2,1 \\
\end{array}$ & $\begin{array}{l}2,2 \\
2,2 \\
2,2 \\
2,1 \\
2,1 \\
2,2 \\
\end{array}$ & $\begin{array}{l}2,2 \\
2,2 \\
2,2 \\
2,2 \\
2,2 \\
2,2\end{array}$ \\
\hline & 40 & $\begin{array}{l}3,6 \\
3,6 \\
3,6 \\
3,9 \\
3,7 \\
3,6 \\
\end{array}$ & $\begin{array}{l}2,5 \\
2,5 \\
2,5 \\
2,6 \\
2,5 \\
2,5 \\
\end{array}$ & $\begin{array}{l}2,5 \\
2,5 \\
2,5 \\
2,5 \\
2,6 \\
2,5 \\
\end{array}$ \\
\hline & 25 & $\begin{array}{l}23,9 \\
24,4 \\
23,8 \\
24,0 \\
23,8 \\
24,0 \\
\end{array}$ & $\begin{array}{l}10,9 \\
11,2 \\
12,5 \\
9,7 \\
9,8 \\
9,7 \\
\end{array}$ & $\begin{array}{l}- \\
- \\
- \\
- \\
- \\
-\end{array}$ \\
\hline & 0 & $\begin{array}{l}119,2 \\
112,6 \\
114,0 \\
114,4 \\
113,1 \\
114,5 \\
\end{array}$ & $\begin{array}{l}105,8 \\
106,6 \\
107,5 \\
109,0 \\
106,1 \\
109,5 \\
\end{array}$ & $\begin{array}{l}- \\
- \\
- \\
- \\
- \\
\end{array}$ \\
\hline
\end{tabular}


Tabela A.IV: Absorção de água por capilaridade concreto / pintura Concreto fck $=20 \mathrm{MPa}$

\begin{tabular}{|c|c|c|c|c|c|c|c|c|c|c|}
\hline \multirow{3}{*}{$\begin{array}{c}\text { Tinta } \\
(P V C \text { \% })\end{array}$} & \multirow{3}{*}{$\mathbf{c p ~ n}^{\circ}$} & \multicolumn{9}{|c|}{ Absorção (\%) } \\
\hline & & \multicolumn{9}{|c|}{ Horas de exposicão } \\
\hline & & 1. & 3 & 5 & 6 & 24 & 48 & 72 & 96 & 168 \\
\hline \multirow{6}{*}{ Referência } & 1 & 2,02 & 2,72 & 3,04 & 3,19 & 3,67 & 3,75 & 3,77 & 3,77 & 3,84 \\
\hline & 2 & 2,24 & 3,02 & 3,33 & 3,43 & 3,78 & 3,84 & 3,88 & 3,89 & 3,95 \\
\hline & 3 & 0,61 & 1,09 & $1 ; 39$ & 0,97 & 2,74 & 3,07 & 3,20 & 3,22 & 3,34 \\
\hline & 4 & 1,43 & 2,12 & 2,44 & 2,59 & 3,26 & 3,34 & 3,36 & 3,37 & 3,43 \\
\hline & média & 1,58 & 2,24 & 2,55 & 2,55 & 3,36 & 3,50 & 3,55 & 3,56 & 3,64 \\
\hline & $\mathbf{s}$ & 0,73 & 0,85 & 0,86 & 1,11 & 0,47 & 0,36 & 0,33 & 0,32 & 0,30 \\
\hline \multirow{6}{*}{75} & 1 & 0,44 & 0,66 & 0,87 & 0,93 & 2,16 & 2,83 & 2,95 & 2,94 & 2,99 \\
\hline & 2 & 0,39 & 0,56 & 0,74 & 0,80 & 2,32 & 3,19 & 3,35 & 3,36 & 3,44 \\
\hline & 3 & 0,33 & 0,44 & 0,58 & 0,62 & 1,39 & 2,37 & 3,05 & 3,32 & 3,67 \\
\hline & 4 & 0,55 & 0,94 & 1,26 & 1,41 & 2,98 & 3,36 & 3,48 & 3,49 & 3,59 \\
\hline & média & 0,43 & 0,65 & 0,86 & 0,94 & 2,21 & 2,93 & 3,21 & 3,28 & 3,42 \\
\hline & $\mathbf{s}$ & 0,10 & 0,21 & 0,29 & 0,33 & 0,65 & 0,44 & 0,25 & 0,24 & 0,30 \\
\hline \multirow{6}{*}{60} & 1 & 0,14 & 0,20 & 0,28 & 0,30 & 0,73 & 1,25 & 1,65 & 1,89 & 2,24 \\
\hline & 2 & 0,16 & 0,24 & 0,35 & 0,38 & 0,99 & 1,51 & 1,91 & 2,26 & 2,71 \\
\hline & 3 & 0,18 & 0,33 & 0,45 & 0,49 & 1,02 & 1,53 & 1,93 & 2,16 & 2,60 \\
\hline & 4 & 0,19 & 0,24 & 0,36 & 0,37 & 0,91 & 1,41 & 1,79 & 2,04 & 2,48 \\
\hline & média & 0,17 & 0,25 & 0,36 & 0,39 & 0,91 & 1,42 & 1,82 & 2,09 & 2,51 \\
\hline & $\mathbf{s}$ & 0,02 & 0,06 & 0,07 & 0,08 & 0,13 & 0,13 & 0,13 & 0,16 & 0,20 \\
\hline \multirow{6}{*}{40} & 1 & 0,07 & 0,16 & 0,23 & 0,31 & 0,67 & 1,07 & 1,38 & 1,60 & 2,05 \\
\hline & 2 & 0,07 & 0,13 & 0,19 & 0,22 & 0,52 & 0,88 & 1,20 & 1,45 & 2,01 \\
\hline & 3 & 0,06 & 0,13 & 0,18 & 0,22 & 0,46 & 0,81 & 1,15 & 1,44 & 2,11 \\
\hline & 4 & 0,06 & 0,11 & 0,17 & 0,18 & 0,38 & 0,66 & 0,92 & 1,14 & 1,71 \\
\hline & média & 0,07 & 0,13 & 0,19 & 0,23 & 0,51 & 0,85 & 1,16 & 1,41 & 1,97 \\
\hline & $\mathbf{s}$ & 0,01 & 0,02 & 0,03 & 0,06 & 0,12 & 0,17 & 0,19 & 0,19 & 0,18 \\
\hline \multirow{6}{*}{25} & 1 & 0,00 & 0,10 & 0,10 & 0,10 & 0,50 & 0,70 & 0,90 & 1,20 & 1,80 \\
\hline & 2 & 0,10 & 0,10 & 0,10 & 0,10 & 0,30 & 0,50 & 0,70 & 0,80 & 1,20 \\
\hline & 3 & 0,10 & 0,10 & 0,10 & 0,10 & 0,40 & 0,50 & 0,70 & 0,90 & 1,30 \\
\hline & 4 & 0,10 & 0,10 & 0,20 & 0,20 & 0,70 & 1,00 & 1,20 & 1,40 & 1,80 \\
\hline & média & 0,10 & 0,10 & 0,10 & 0,10 & 0,50 & 0,70 & 0,90 & 1,10 & 1,50 \\
\hline & $\mathbf{s}$ & 0,00 & 0,00 & 0,00 & 0,00 & 0,20 & 0,20 & 0,30 & 0,30 & 0,30 \\
\hline \multirow{6}{*}{ 0 } & 1 & 0,06 & 0,06 & 0,12 & 0,10 & 0,16 & 0,23 & 0,31 & 0,36 & 0,42 \\
\hline & 2 & 0,04 & 0,05 & 0,09 & 0,07 & 0,08 & 0,13 & 0,16 & 0,19 & 0,26 \\
\hline & 3 & 0,06 & 0,05 & 0,10 & 0,09 & 0,09 & 0,15 & 0,18 & 0,21 & 0,26 \\
\hline & 4 & 0,06 & 0,05 & 0,12 & 0,10 & 0,10 & 0,16 & 0,22 & 0,25 & 0,33 \\
\hline & média & 0,05 & 0,05 & 0,11 & 0,09 & 0,11 & 0,17 & 0,22 & 0,25 & 0,32 \\
\hline & $\mathbf{s}$ & 0,01 & 0,01 & 0,02 & 0,01 & 0,04 & 0,04 & 0,06 & 0,08 & 0,08 \\
\hline
\end{tabular}

Observação:

s: desvio padrão 
Tabela A.V: Absorção de água por capilaridade concreto / pintura Concreto fck $=40 \mathrm{MPa}$

\begin{tabular}{|c|c|c|c|c|c|c|c|c|c|c|}
\hline \multirow{3}{*}{$\begin{array}{l}\text { Tinta } \\
(P V C \%)\end{array}$} & \multirow{3}{*}{ cp n } & \multicolumn{9}{|c|}{ Absorcão $(\%)$} \\
\hline & & & \multicolumn{3}{|c|}{ Horas de exposição } & \multirow[b]{2}{*}{72} & \multirow[b]{2}{*}{96} & \multirow[b]{2}{*}{168} \\
\hline & & 1 & 3 & 5 & 6 & 24 & 48 & & & \\
\hline \multirow{6}{*}{ Referência } & 1 & 0,29 & 0,36 & 0,43 & 0,48 & 0,79 & 1,06 & 1,20 & 1,28 & 1,39 \\
\hline & 2 & 0,84 & 1,04 & 1,10 & 1,33 & 1,90 & 2,00 & 2,05 & 2,06 & 2,13 \\
\hline & 3 & 0,52 & 0,72 & 0,84 & 0,90 & 1,46 & 1,75 & 1,82 & 1,83 & 1,88 \\
\hline & 4 & 0,26 & 0,34 & 0,38 & 0,42 & 0,68 & 0,89 & 1,01 & 1,07 & 1,16 \\
\hline & média & 0,48 & 0,61 & 0,69 & 0,78 & 1,21 & 1,43 & 1,52 & 1,56 & 1,64 \\
\hline & $s$ & 0,27 & 0,33 & 0,34 & 0,42 & 0,58 & 0,53 & 0,49 & 0,46 & 0,44 \\
\hline \multirow{6}{*}{75} & 1 & 0,23 & 0,28 & 0,34 & 0,38 & 0,62 & 0,83 & 1,01 & 1,09 & 1,23 \\
\hline & 2 & 0,22 & 0,28 & 0,32 & 0,37 & 0,54 & 0,72 & 0,86 & 0,96 & 1,17 \\
\hline & 3 & 0,30 & 0,36 & 0,45 & 0,49 & 0,79 & 1,04 & 1,21 & 1,31 & 1,49 \\
\hline & 4 & 0,36 & 0,44 & 0,53 & 0,57 & 0,85 & 1,05 & 1,18 & 1,26 & 1,24 \\
\hline & média & 0,28 & 0,34 & 0,41 & 0,45 & 0,70 & 0,91 & 1,06 & 1,16 & 1,28 \\
\hline & $\mathrm{s}$ & 0,06 & 0,08 & 0,10 & 0,10 & 0,14 & 0,16 & 0,16 & 0,16 & 0,14 \\
\hline \multirow{6}{*}{60} & 1 & 0,21 & 0,25 & 0,31 & 0,34 & 0,58 & 0,82 & 1,01 & 1,12 & 1,27 \\
\hline & 2 & 0,17 & 0,20 & 0,29 & 0,31 & 0,64 & 0,98 & 1,25 & 1,39 & 1,60 \\
\hline & 3 & 0,13 & 0,15 & 0,22 & 0,24 & 0,47 & 0,68 & 0,83 & 0,94 & 1,13 \\
\hline & 4 & 0,12 & 0,13 & 0,17 & 0,18 & 0,24 & 0,32 & 0,37 & 0,42 & 0,50 \\
\hline & média & 0,16 & 0,19 & 0,25 & 0,27 & 0,48 & 0,70 & 0,87 & 0,97 & 1,13 \\
\hline & $s$ & 0,04 & 0,05 & 0,06 & 0,07 & 0,17 & 0,28 & 0,37 & 0,41 & 0,46 \\
\hline \multirow{6}{*}{40} & 1 & 0,05 & 0,09 & 0,13 & 0,15 & 0,33 & 0,64 & 0,88 & 1,04 & 1,38 \\
\hline & 2 & 0,09 & 0,15 & 0,20 & 0,25 & 0,50 & 0,77 & 0,95 & 1,08 & 1,31 \\
\hline & 3 & 0,06 & 0,11 & 0,15 & 0,19 & 0,43 & 0,72 & 0,97 & 1,13 & 1,41 \\
\hline & 4 & 0,08 & 0,14 & 0,17 & 0,20 & 0,32 & 0,45 & 0,54 & 0,59 & 0,74 \\
\hline & média & 0,07 & 0,12 & 0,16 & 0,20 & 0,39 & 0,65 & 0,84 & 0,96 & 1,21 \\
\hline & $\mathrm{s}$ & 0,02 & 0,03 & 0,03 & 0,04 & 0,09 & 0,14 & 0,20 & 0,25 & 0,32 \\
\hline \multirow{6}{*}{25} & 1 & 0,06 & 0,13 & 0,17 & 0,19 & 0,46 & 0,58 & 0,75 & 0,89 & 1,19 \\
\hline & 2 & 0,07 & 0,15 & 0,22 & 0,23 & 0,56 & 0,69 & 0,85 & 1,00 & 1,27 \\
\hline & 3 & 0,05 & 0,13 & 0,18 & 0,19 & 0,48 & 0,60 & 0,76 & 0,90 & 1,18 \\
\hline & 4 & 0,05 & 0,11 & 0,14 & 0,16 & 0,38 & 0,49 & 0,65 & 0,77 & 1,02 \\
\hline & média & 0,06 & 0,13 & 0,18 & 0,19 & 0,47 & 0,59 & 0,75 & 0,89 & 1,17 \\
\hline & $s$ & 0,01 & 0,02 & 0,03 & 0,03 & 0,08 & 0,08 & 0,08 & 0,09 & 0,11 \\
\hline \multirow{6}{*}{0} & 1 & 0,04 & 0,05 & 0,06 & 0,06 & 0,07 & 0,11 & 0,15 & 0,16 & 0,24 \\
\hline & 2 & 0,04 & 0,05 & 0,07 & 0,09 & 0,15 & 0,21 & 0,27 & 0,32 & 0,43 \\
\hline & 3 & 0,04 & 0,05 & 0,10 & 0,09 & 0,10 & 0,17 & 0,20 & 0,24 & 0,32 \\
\hline & 4 & 0,04 & 0,05 & 0,06 & 0,08 & 0,10 & 0,13 & 0,19 & 0,22 & 0,32 \\
\hline & média & 0,04 & 0,05 & 0,07 & 0,08 & 0,11 & 0,15 & 0,20 & 0,24 & 0,33 \\
\hline & $s$ & 0,00 & 0,00 & 0,02 & 0,01 & 0,03 & 0,04 & 0,05 & 0,07 & 0,08 \\
\hline
\end{tabular}

Observação:

s: desvio padrão 


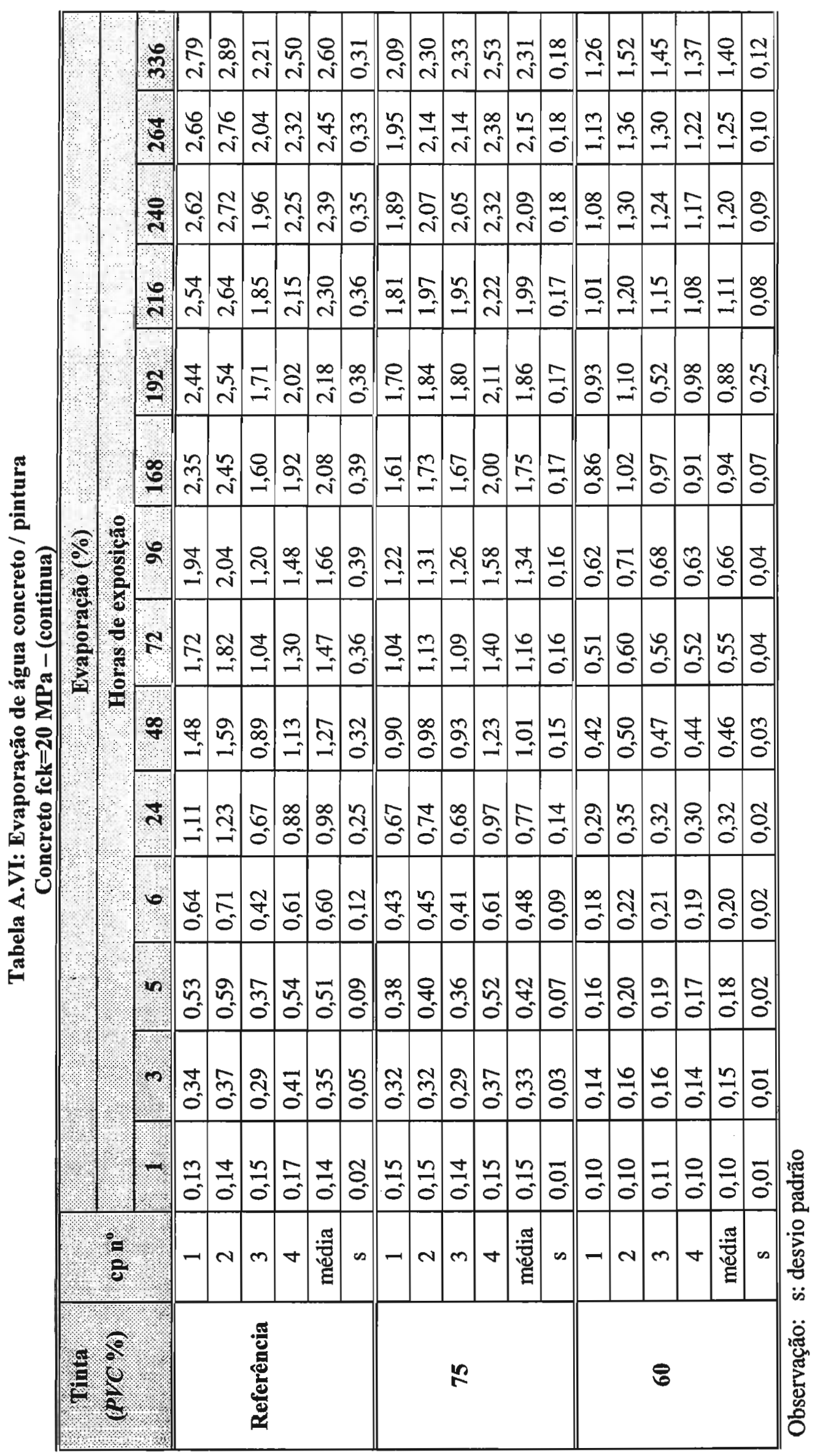




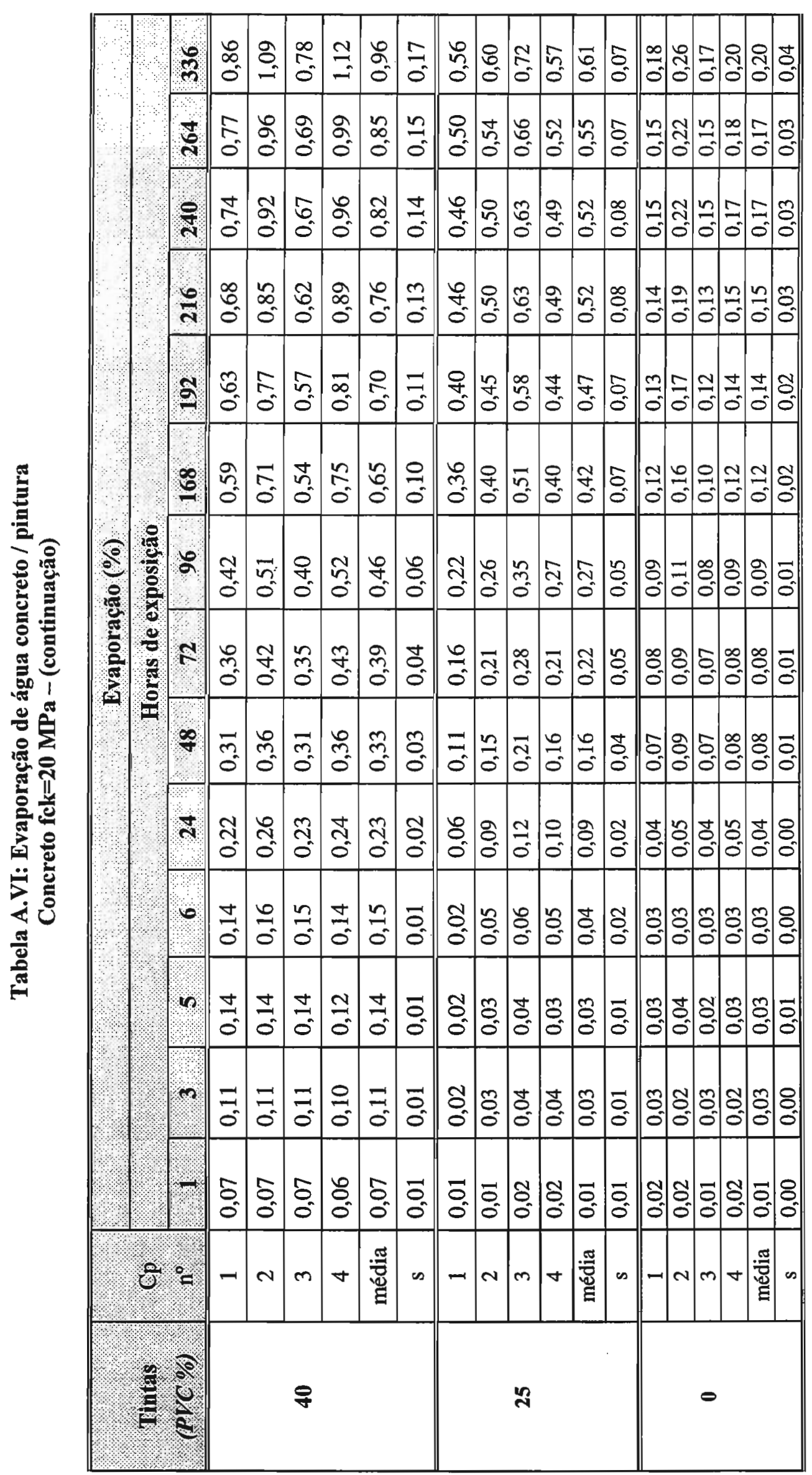




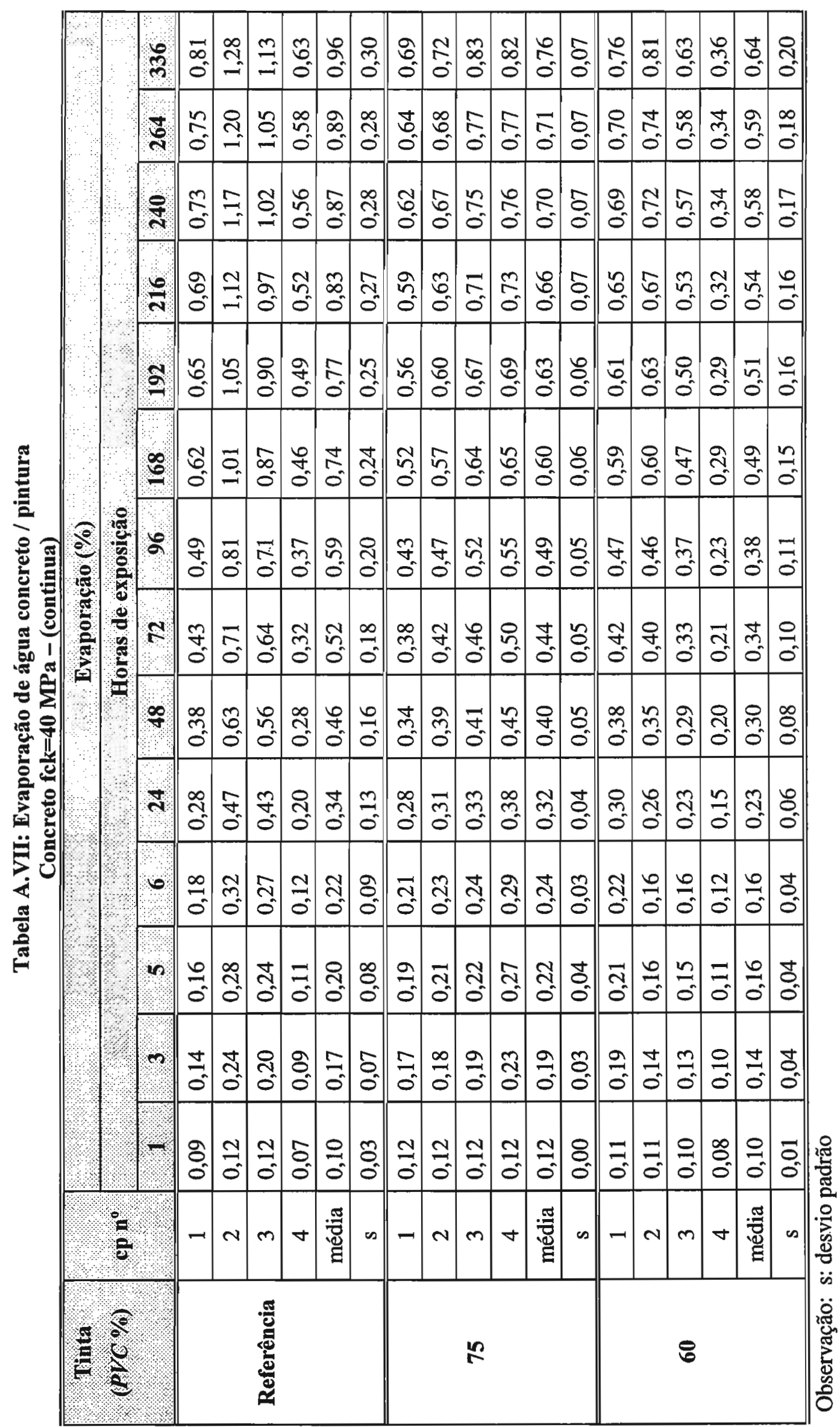




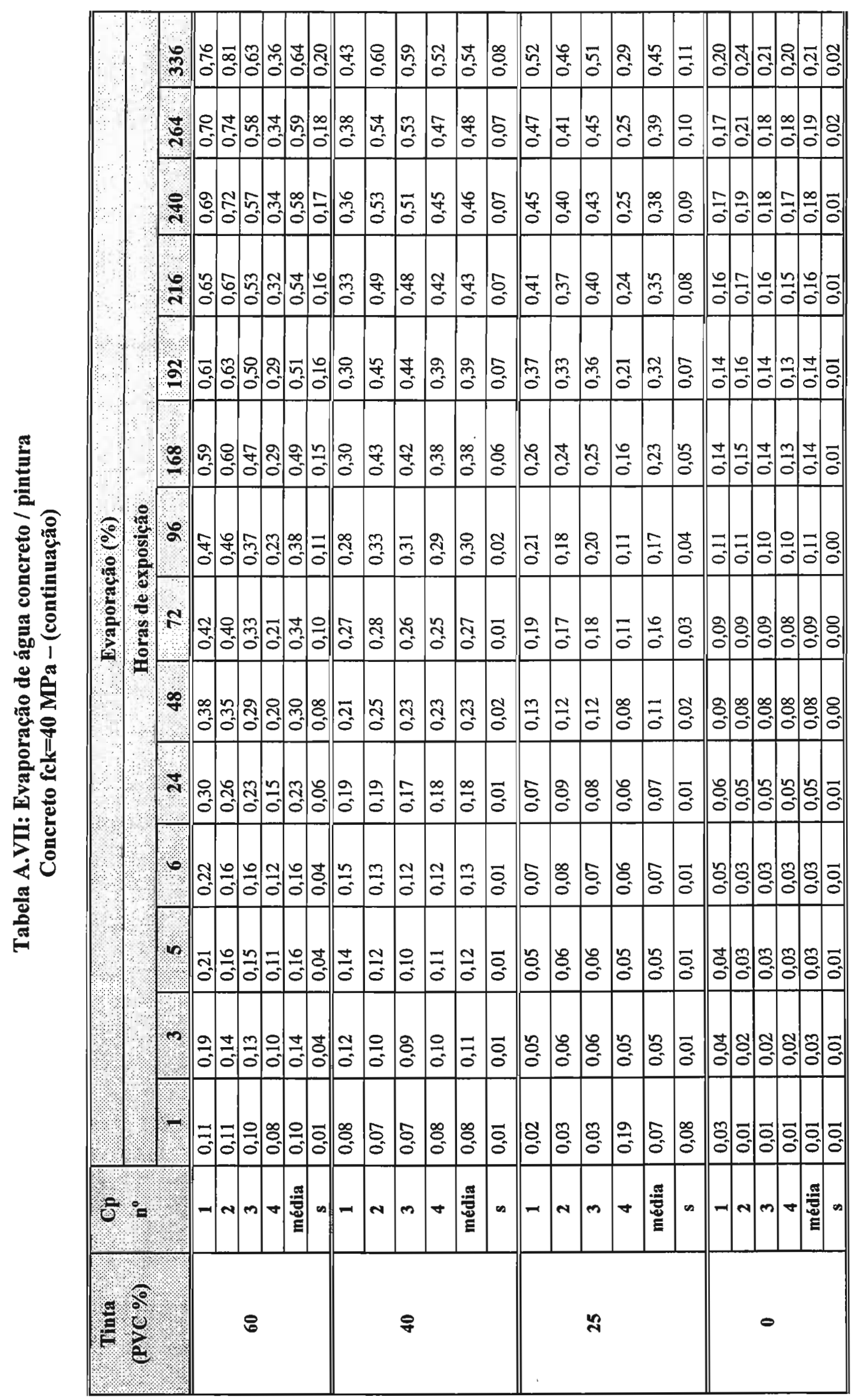



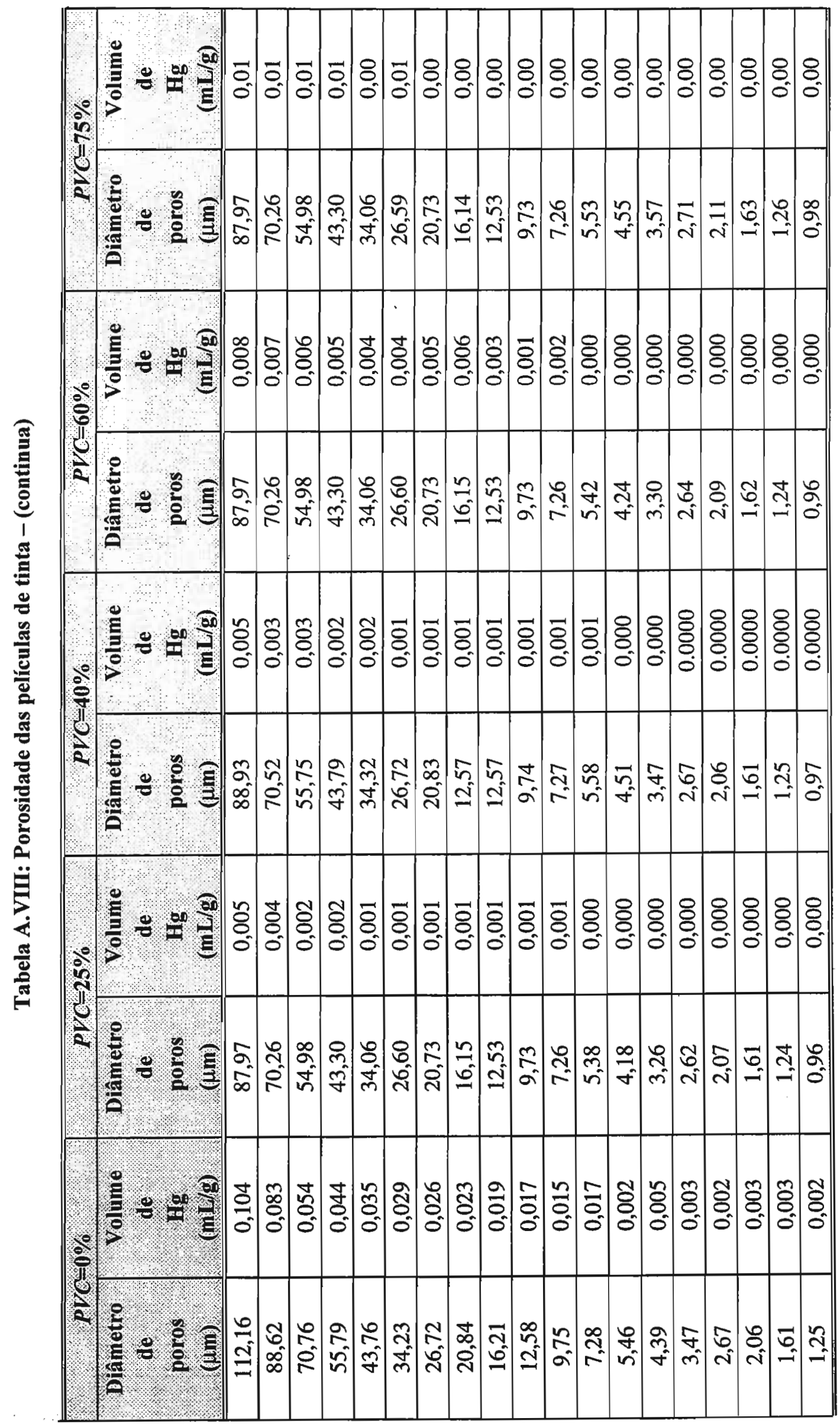


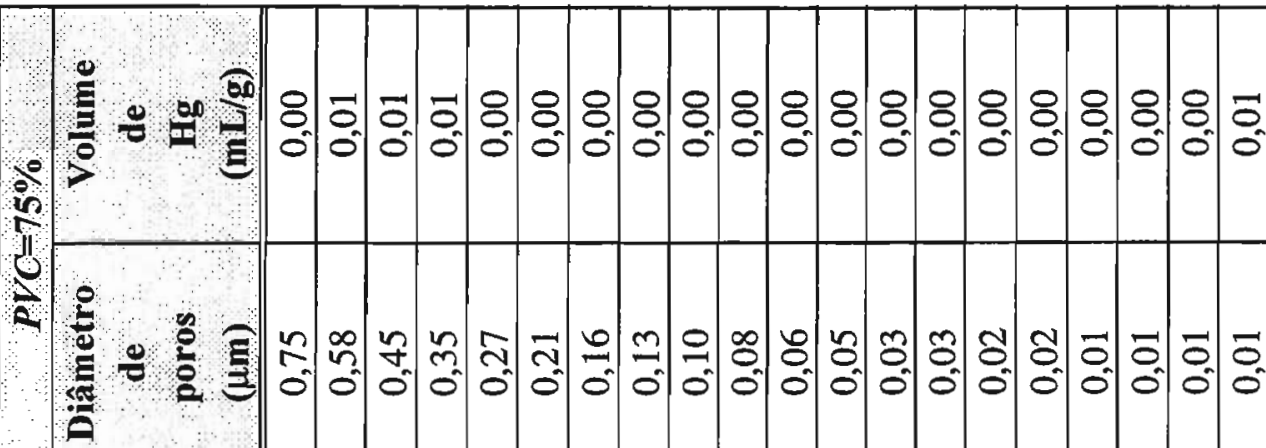

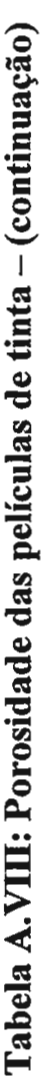

है

2

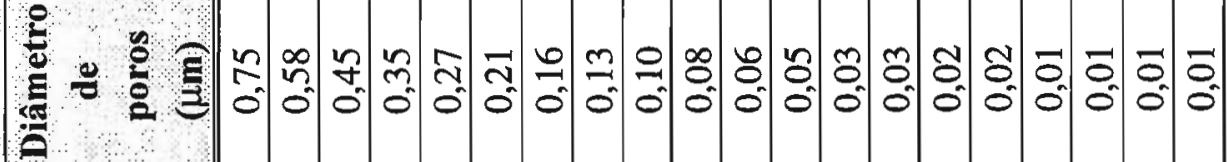

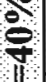

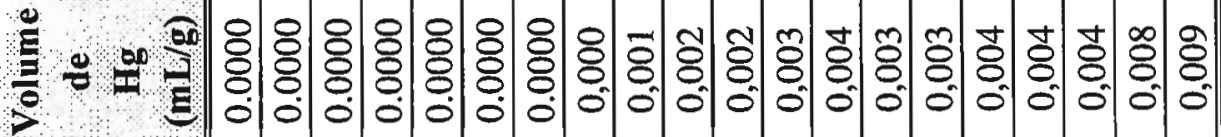

2.

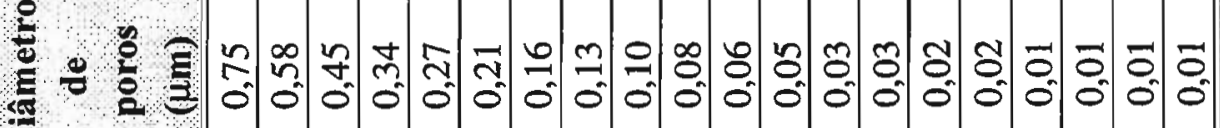

б

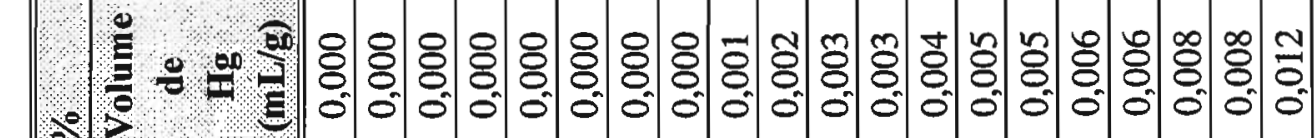

$\frac{1}{8}$

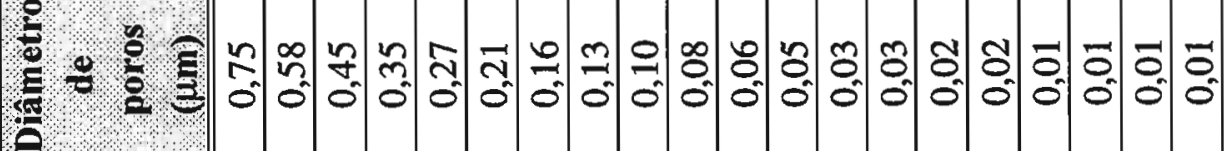

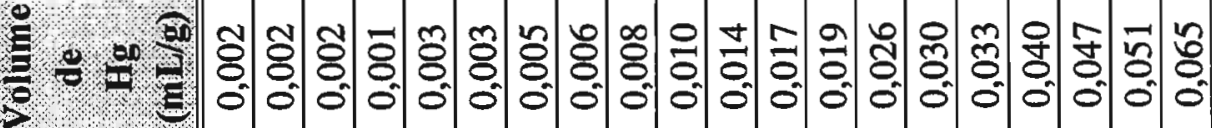

$-$

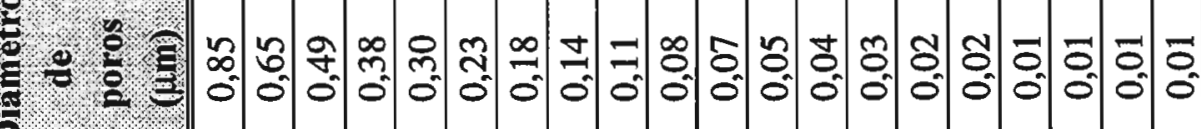




\section{ANEXO B \\ Preparação dos substratos de concreto}

\subsection{Procedência dos materiais}

Os materiais constituintes dos concretos possuem as seguintes procedências:

- Cimento: tipo I, marca Itambé;

- Agregados: brita 1 proveniente da pedreira Riúma e areia média do rio Tietê.

\subsection{Caracterização dos materiais}

Os materiais adquiridos no mercado como matéria prima para o preparo dos corpos-deprova, a serem usados como referência no estudo, foram caracterizados e os resultados do cimento estão apresentados nas Tabelas B.1, B.2 e B.3, os de areia nas Tabelas B.4 e B.5 e os de brita nas Tabelas B.6 e B.7 apresentadas a seguir:

\section{Cimento}

Tabela B.1: Composição química

\begin{tabular}{|l|c|}
\hline \multicolumn{1}{|c|}{ Determinacões } & Resultados (\%) \\
\hline Perda ao fogo & 3,98 \\
\hline Anidrido silício $\left(\mathrm{SiO}_{2}\right)$ & 19,0 \\
\hline Óxido de alumínio $\left(\mathrm{Al}_{2} \mathrm{O}_{3}\right)$ & 5,41 \\
\hline Óxido de ferro $\left(\mathrm{Fe}_{2} \mathrm{O}_{3}\right)$ & 2,47 \\
\hline Óxido de cálcio $(\mathrm{CaO})$ & 62,5 \\
\hline Óxido de magnésio $(\mathrm{MgO})$ & 2,64 \\
\hline Anidrido sulfúrico $\left(\mathrm{SO}_{3}\right)$ & 3,02 \\
\hline Óxido de potássio $\left(\mathrm{K}_{2} \mathrm{O}\right)$ & 0,83 \\
\hline Óxido de sódio $\left(\mathrm{Na}_{2} \mathrm{O}\right)$ & 0,03 \\
\hline Resíduo insolúvel $(\mathrm{RI}$ & 0,42 \\
\hline Óxido de cálcio livre $(\mathrm{em} \mathrm{CaO})$ & 2,52 \\
\hline \hline Anidrido carbônico $\left(\mathrm{CO}_{2}\right)$ & 2,32 \\
\hline
\end{tabular}


Tabela B.2: Resultados de ensaios físicos

\begin{tabular}{|l|c|}
\hline \multicolumn{1}{|c|}{ Determinações } & Resultados \\
\hline Finura (NBR - 11579/91) Resíduo na peneira de 0,075 mm (\%) & 3,0 \\
\hline Massa específica (NBR - 6474/84) $\left(\mathrm{kg} / \mathrm{m}^{2}\right)$ & 3,11 \\
\hline Área específica (NBR - 7224/84) $\left(\mathrm{m}^{2} / \mathrm{kg}\right)$ & 306 \\
\hline Água para pasta normal (NBR - 11580/91) (\% peso de cimento) & 26,8 \\
\hline Início de pega (NBR - 11581/91) (min) & 235 \\
\hline Fim de pega (NBR - 11581/91) (min) & 325 \\
\hline Expansibilidade (NBR - 11582/91) - Frio (mm) & 0,0 \\
\hline Expansibilidade (NBR - 11582/91) - Quente $(5 \mathrm{~h})(\mathrm{mm})$ & 0,0 \\
\hline Índice de consistência da argamassa (NBR - $7215 / 91)(\mathrm{mm})$ & 165 \\
\hline
\end{tabular}

Tabela B.3: Resistência à compressão - NBR - 7215/91

\begin{tabular}{|c|c|c|c|c|c|c|}
\hline \multirow{2}{*}{$\begin{array}{l}\text { Idades } \\
\text { (dias) }\end{array}$} & \multicolumn{4}{|c|}{ Resistência à compressão (MPa) - cp n } & \multirow{2}{*}{$\begin{array}{l}\text { Média } \\
\text { (MPa) }\end{array}$} & \multirow{2}{*}{$\begin{array}{c}\text { DRM } \\
(\%)\end{array}$} \\
\hline & 1 & 2 & 3 & 4 & & \\
\hline 3 & 22,0 & 22,1 & 22,3 & 22,3 & 22,2 & 0,9 \\
\hline 7 & 30,2 & 29,6 & 30,6 & 29,7 & 30,0 & 2,0 \\
\hline 28 & 36,3 & 37,0 & 36,9 & 36,5 & 36,7 & 1,1 \\
\hline
\end{tabular}

* DRM - diferença máxima entre um resultado individual e a média 
Agregados

Tabela B.4: Composição granulométrica da areia

\begin{tabular}{|c|c|c|c|}
\hline & Peneira & Material retido (\%) \\
\hline Desionacão & Abertura de malha & Individual & Acumulado \\
\hline $\mathrm{n}^{\circ} 4$ & 4,8 & 0 & 0 \\
\hline $\mathrm{n}^{\circ} 8$ & 2,4 & 3 & 3 \\
\hline $\mathrm{n}^{\circ} 16$ & 1,2 & 9 & 12 \\
\hline $\mathrm{n}^{\circ} 30$ & 0,6 & 17 & 29 \\
\hline $\mathrm{n}^{\mathrm{o}} 50$ & 0,3 & 21 & 50 \\
\hline $\mathrm{n}^{\mathrm{o}} 10^{\circ}$ & 0,15 & 39 & 89 \\
\hline$<\mathrm{n}^{\circ} 100$ & $<0,15$ & 11 & 100 \\
\hline \hline Totais & & 100 & 183 \\
\hline \hline Dimensão máxima característica $(\mathrm{mm})$ & 2,4 & - \\
\hline Módulo de finura & & - & 1,83 \\
\hline
\end{tabular}

Tabela B.5: Características físicas da areia

\begin{tabular}{|l|c|}
\hline Massa específica (Frasco de Chapman - NBR 9776-87) $\left(\mathrm{g} / \mathrm{cm}^{3}\right)$ & 2,65 \\
\hline \hline Massa unitária seca (NBR 7251-82) $\left(\mathrm{kg} / \mathrm{m}^{3}\right)$ & 1480 \\
\hline \hline Teor de argila em torrões (NBR 7218-87) $(\%)$ & 1,2 \\
\hline \hline Teor de materiais pulverulentos (NBR 7219-87) (\%) & 1,0 \\
\hline \hline Índice de matéria orgânica (NBR 7220-87) & $<300 \mathrm{ppm}$ \\
\hline
\end{tabular}


Tabela B.6: Composição granulométrica da brita (NBR 7217-87)

\begin{tabular}{|c|c|c|c|}
\hline \multicolumn{2}{|c|}{ Peneira } & \multicolumn{2}{|c|}{ Material retido $(\%)$} \\
\hline Besignaçâo & Abertura de malha & Individual & Acumulado \\
\hline $3 / 4$ in. & 19 & 0 & 0 \\
\hline $1 / 2$ in & $12,5^{*}$ & 64 & 64 \\
\hline $3 / 8$ in. & 9,5 & 33 & 97 \\
\hline $1 / 4$ in. & $6,3 *$ & 3 & 100 \\
\hline$n \stackrel{0}{4}$ & 4,8 & 0 & 100 \\
\hline$<\mathrm{n}^{\circ} 4$ & $<4,8$ & 0 & 100 \\
\hline $\mathrm{n}^{\mathrm{o}} 16$ & 1,2 & & 100 \\
\hline $\mathrm{n}^{\circ} 30$ & 0,6 & - & 100 \\
\hline $\mathrm{n}^{0} 50$ & 0,3 & - & 100 \\
\hline $\mathrm{n}^{\mathrm{o}} 100$ & 0,15 & - & 100 \\
\hline \multicolumn{2}{|c|}{$\begin{array}{c}\text { Totais } \\
\end{array}$} & - & 697 \\
\hline \multicolumn{2}{|c|}{ Dimensão máxima característica (mm) } & 19 & - \\
\hline \multicolumn{2}{|c|}{ Módulo de finura } & - & 6,97 \\
\hline
\end{tabular}

* Peneiras intermediárias que não fazem parte da série normal conforme NBR $7217 / 87$.

Tabela B.7: Características físicas da brita

\begin{tabular}{|l|c|}
\hline Massa específica (NBR 9937-87) $\left(\mathrm{g} / \mathrm{cm}^{3}\right)$ & 2,64 \\
\hline Massa unitária (NBR 7251-87) $\left(\mathrm{g} / \mathrm{cm}^{3}\right)$ & 1,40 \\
\hline Teor de materiais pulverulentos (NBR $7219-87)(\%)$ & 0,8 \\
\hline
\end{tabular}

\subsection{Dosagem experimental}

Com os materiais do estudo, foram moldados três traços de concreto, com as características apresentadas na Tabela B.8: 
Tabela B.8: Características dos concretos para dosagem

\begin{tabular}{|c|c|c|c|c|c|}
\hline \multirow{2}{*}{$\begin{array}{c}\text { Traco } \\
\text { (cimento:areia:brita) } \\
(\mathrm{kg} / \mathrm{kg})\end{array}$} & \multirow{2}{*}{$\begin{array}{c}\text { Relação } \\
\mathrm{a} / \mathrm{c} \\
(\mathrm{kg} / \mathrm{kg})\end{array}$} & \multirow{2}{*}{$\begin{array}{l}\text { Agregtotal } \\
\text { cimento } \\
\text { ' }{ }^{\text {m? }} \\
\text { (kg/kg) }\end{array}$} & \multirow{2}{*}{$\begin{array}{c}\text { Consumo } \\
\text { de eimento } \\
-{ }^{-6 \mathrm{C} "} \\
\left(\mathrm{~kg} / \mathrm{m}^{3}\right) \\
\end{array}$} & \multicolumn{2}{|c|}{$\begin{array}{l}\text { Resistência à } \\
\text { compressâo (MPa) }\end{array}$} \\
\hline & & & & 7 dias & 28 dias \\
\hline $1: 1,4: 2,6$ & 0,44 & $\cdot 4,0$ & 443 & 37,1 & 41,0 \\
\hline $1: 1,2: 3,4$ & 0,59 & 5,5 & 338 & 24,0 & 27,1 \\
\hline $1: 2,8: 4,2$ & 0,76 & 7,0 & 271 & 15,8 & 20,6 \\
\hline
\end{tabular}

Estes traços foram moldados com o objetivo de se levantar a curva de dosagem experimental para determinação dos traços de concreto com fck de $20 \mathrm{MPa}$ e $40 \mathrm{MPa}$ que são objetos do estudo. O traço de $20 \mathrm{MPa}$ foi escolhido por representar os concretos usuais do mercado que apresentam fck entre 18 e $22 \mathrm{MPa}$. O concreto de fck $40 \mathrm{MPa}$ foi selecionado por haver uma tendência no mercado de uso de concretos de baixa permeabilidade. Este concreto seria usado como referência para o concreto de baixo fck, que apresenta menor durabilidade em função da sua maior porosidade. Os dados da Tabela B.8 mostram que os próprios traços da moldagem experimental levaram à obtenção dos concretos com as resistências desejadas, não havendo necessidade de calcular os traços teóricos para a moldagem dos corpos-de-prova.

\subsection{Preparação e moldagem de corpos-de-prova}

O concreto foi preparado nos traços definidos na dosagem experimental e moldado em forma de painéis, visando a obtenção de superfícies que simulam o acabamento do concreto obtido em obra. Dentro deste contexto, o concreto foi lançado nas formas de madeira resinada, com dimensões de $50 \mathrm{~cm} \times 100 \mathrm{~cm} \times 5 \mathrm{~cm}$, posicionadas verticalmente e adensado na mesa vibratória e vibrador. As Figuras de B.I a B.III ilustram a preparação dos painéis. 


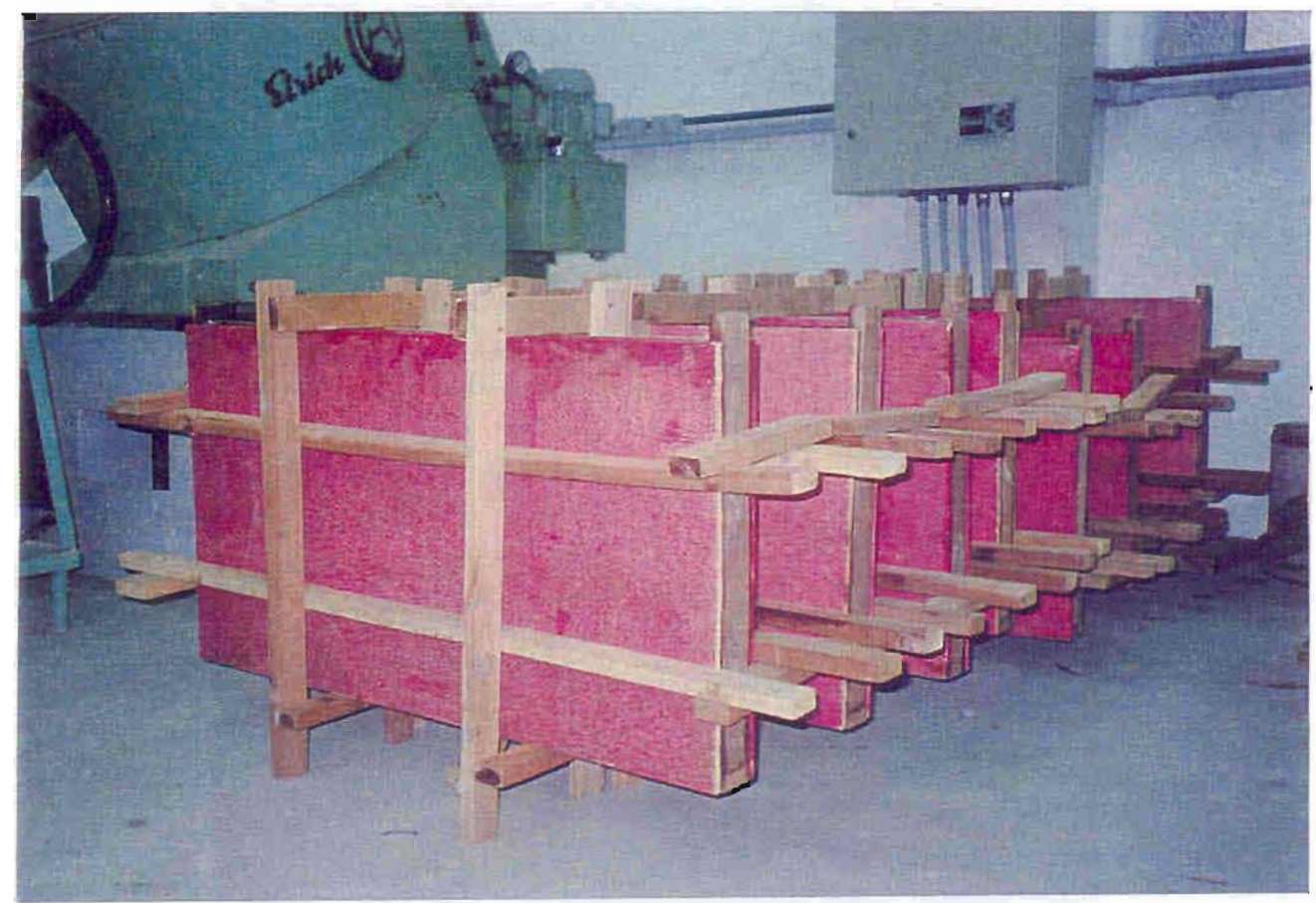

Figura B.I: Aspecto geral das formas

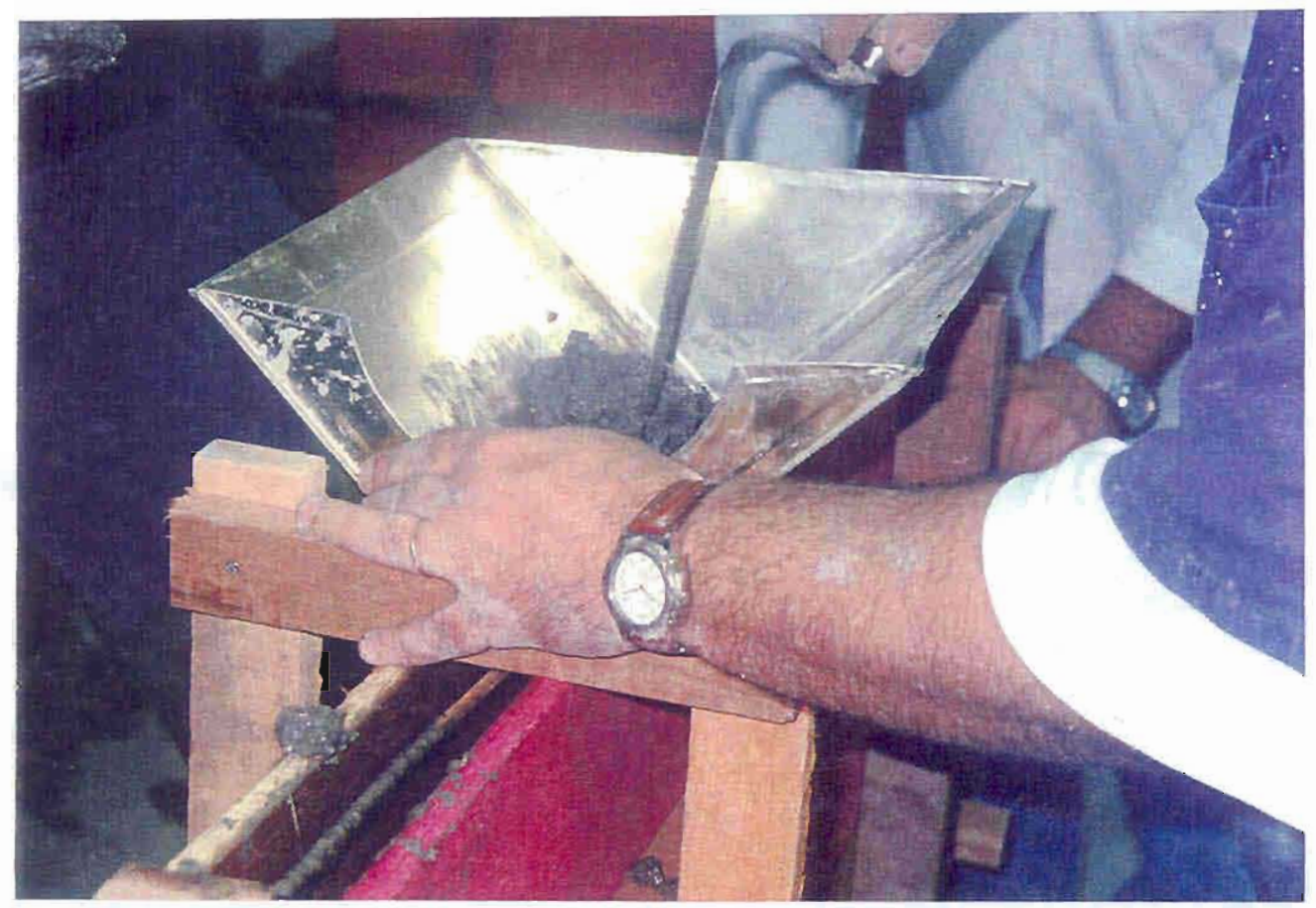

Figura B.II: Preenchimento de forma com funil 


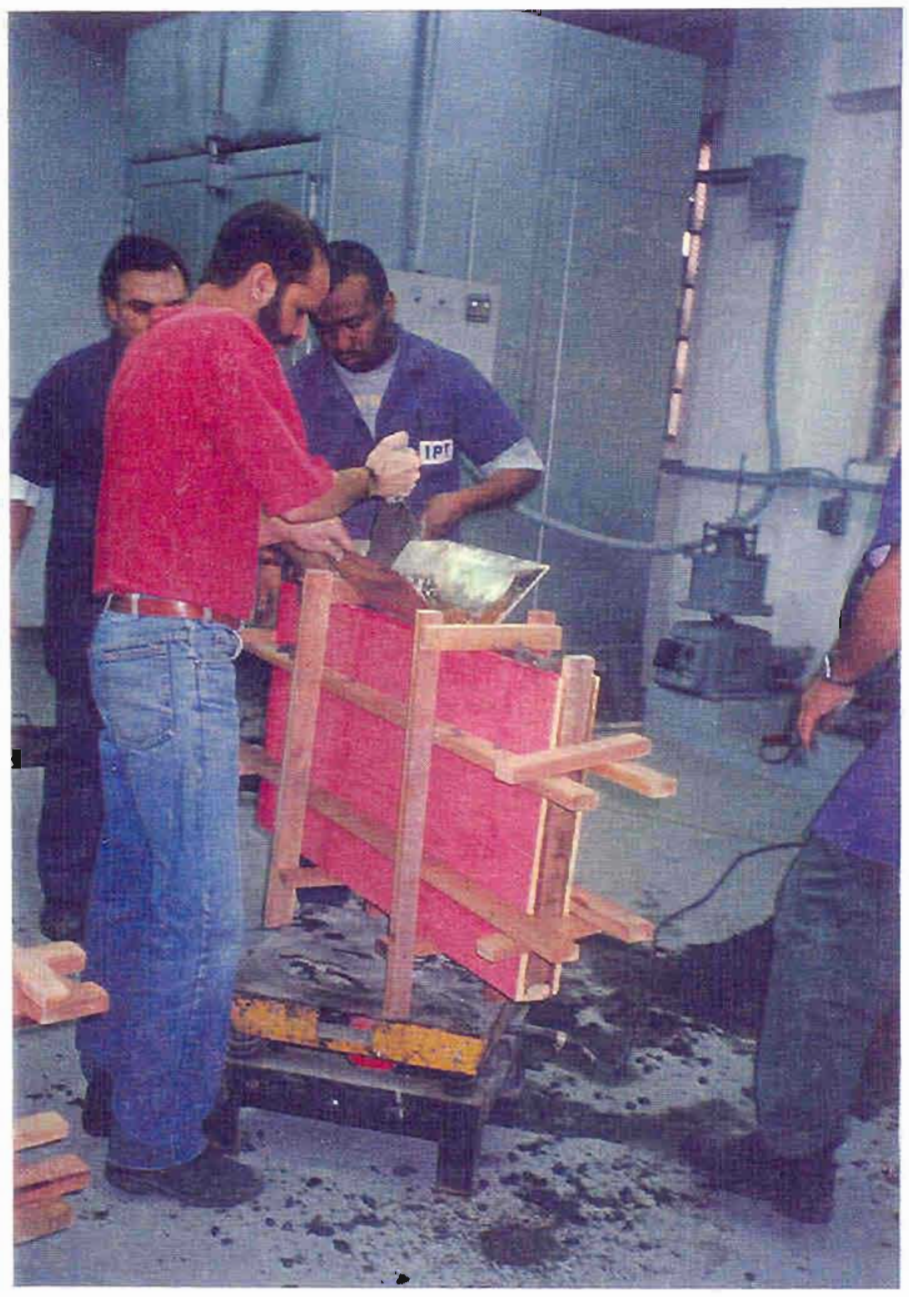

Figura B.II: Adensamento com mesa vibratória 


\section{REFERÊNCIAS BIBLIOGRÁFICAS}

ADDLESON, L. Materials for building. Physical and chemical aspects of matter and strength of materials. London, Chapel River Press, 1972.

AMERICAN CONCRETE INSTITUTE. Guide for the protection of concrete against chemical attack by means of coatings and other corrosion resistant materials. Journal of the American Concrete Institute. ACI committee 515. v.63, n. 12, p.1305-91, 1966.

- A guide to the use of waterproofing, dampproofing, protective and decorative barrier systems for concrete. ACI committee 515. ACI 515.IR-79 (Revisado 1985). In: ACI Manual of concrete practice: Part 5. 1997. MI, 1997.

ALLCOCK, H. R.; LAMPE, F. W. Contemporary polymer chemistry. New Jersey, Prentice-Hall, Inc.,1990.

ALLEMAN,J. E.; RUSSEL, E. K.; LANTZ, W. L.; WUKASCH, R. F. Biofilm cryopreparation for scanning electron microscopy. Water Research. v. 19, n. 8, p. $1073-8,1985$.

AMERICAN SOCIETY for TESTING and MATERIALS. Standard test method for electrical indication of concrete's ability to resist chloride ion penetration; ASTM C 1202. In: Annual Book of ASTM Standards. Philadelphia, v. 04.02, 1995.

- Standard test method for specular gloss. ASTM D-523. In: Annual Book of ASTM Standards; Philadelphia, v. 06.01, 1995. 
- Recommended pratice for operating light and water exposure apparatus (fluorescent UV - condensation type) for exposure of nonmetallic materials; ASTM G-53. In: Annual Book of ASTM Standards. Philadelphia, v. 14.02, 1995.

- Standard practice for atmosferic environmental exposure testing of nonmetallic materials. ASTM G-7. In: Annual Book of ASTM Standards. Philadelphia, v. 14.02, 1995.

- Standard test method for evaluation of visual color difference with a gray scale. ASTM D-2616. In: Annual Book of ASTM Standards. Philadelphia, v. 06.01, 1995.

- Standard test method for indexes of whiteness and yellowness of near-white opaque materials. ASTM E 313. In: Annual Book of ASTM Standards. Philadelphia, v. $06.01,1995$.

—. Standard test method for minimum film formation temperature (MFFT) of emulsion vehicles. ASTM D-2354. In: Annual Book of ASTM Standards Philadelphia, v. 06.03, 1995.

- Standard test method for pigment content of water-emulsion paints by low temperature ashing. ASTM D-3723. In: Annual Book of ASTM Standards. Philadelphia, v. 06.01, 1995.

- Standard test method for scrub resistance of interior latex flat wall paints. ASTM D2486. In: Annual Book of ASTM Standards. Philadelphia, v.06.02, 1995.

—. Standard test method for water vapor trasmission of Organic Coating Films. ASTM D-1653. In: Annual Book of ASTM Standards. Philadelphia. 1995. 
- Standard practice for developing accelerated tests to aid prediction of the service life of building components and materials. ASTM E-632. In: Annual Book of ASTM Standards. Philadelphia. 1995.

ANDRADE, C. Manual para diagnóstico de obras deterioradas por corrosão de armaduras. São Paulo: Pini, 1992.

ANDRADE, C. Calculation of Chloride Diffusion Coefficients in Concrete From Ionic Migration Measurements. Cement and Concrete Research, v. 23, p. 724-42, 1993.

ASBECK, W.K. A critical look at CPVC performance and aplications properties. Journal of Coatings Technology. v.64, n. 806, p.47-58, 1992.

BALFOUR, J. ; HUCHETTE D. Cost-effective use of $\mathrm{TiO}_{2}$ in decorative paints. Paint \& Ink International. v. 8, p. S2-S4, 1995.

BASHEER, P. A. M.; MONTGOMERY, F. R; LONG, A. E.; BATAYNEH, M. Durability of surface treated concrete. DHIR, R. K.; GREEN, J. W. ed. In: Protection of concrete. London, Chapman and Hall, 1990, p. $211-221$.

BENTZ, D. P.; NGUYEN, T. Simulation of diffusion in pigmented coatings on metals using Monte-Carlo Methods, Journal of Coatings Technology, v 62, n. 783, 1990.

BREZINSKI, J. J. Regulation of volatile organic compound emissions from paints and coatings. KOLESKE, J.V. ed. In: Paint and coating testing manual: fourteenth edition of the Gardner-Sward handbook. ASTM Manual Series: MNL 17, p.3$12,1995$.

BRITISH STANDARDS INSTITUTION. Specification for water repellents for masonry surfaces. BS 6477-92. London, 1998. 
BRITISH STANDARDS INSTITUTION. Porosity and pore size distribution of materials. Method of evaluation by mercury porosimetry. BS 7591: Part 1. London, 1993.

BRITISH STANDARDS INSTITUTION. Porosity and pore size distribution of materials. Method of evaluation by liquid expulsion. BS 7591: Part 4.. London, 1993.

BOUNY, V. B. Caractérisation des pâtes de ciment et des bétons. Méthodes, analyse, interpretations. Laboratoire Central des Pont et Chaussées-LCPC. IST- Section des publications. Paris. 1994

COMITE EURO-INTERNACIONAL du BETON. Durable Concrete Structures. CEB Design Guide. Lausanne, june 1989. (Bulletin D’information, 182).

COPPOLA, L. ; PISTOLESI, C.; ZAFFARONI, P.; COLLEPARDI, M. Aging effect on the properties of flexible surface coating for concrete protection. In: International Conference of Durability of Concrete. 4. Sydney; London, SP 170-63, p. 124757, 1997.

DANIELS, C. A, Polymers: structure and proprerties. Lancaster, Technomic Publishing Company, Inc. 1989.

DAVIES, H. The effect of weathering on carbon dioxide resistance of coatings. NAGATAKI S; NIREKI, T.; TOMOSAWA, F. NAGATAKI, S.; NIREKI, T.; TOMOSAWA, F. ed. In: Durability of Building Materials and Components 6; London, E \& FN Spon. p. 517-26, 1993

DERUELLE, S. Rôle du support dans la croissance des microorganismes. Materials and Structures, v. 24, p. 163-168, 1991. 
DINIZ, F. D.; GNECCO, C. Pintura de manutenção industrial. In: Tintas e Vernizes: Ciência e Tecnologia. São Paulo: ABRAFATI, 1993, p. 864 - 905.

DHIR, R. K.; GREEN, J. W. Protection of concrete. E. \& F.N. SPON. 1990.p. 1090.

ELFRING, W. H. Pure acrylic emulsion for exterior coatings. In: QUARTO CONGRESSO INTERNACIONAL DE TINTAS, Anais. São Paulo, 1995.

FAZENDA, J. M. R.; DINIZ, F. D. Introdução, história e composição básica. In: Tintas e Vernizes: Ciência e Tecnologia. São Paulo: ABRAFATI, 1993, p. 33 - 42.

FAZENDA, J. M. R. Resinas acrílicas e dispersões aquosas. In: Tintas e Vernizes: Ciência e Tecnologia. São Paulo: ABRAFATI, 1993, p. 398 - 450.

FELDMAN, D. Polymeric building materials. London, Elsevier Science Publishers LTD, 1989.

FLAUZINO, W. D. Durabilidade de materiais e componentes das edificações. Metodologias e suas aplicações no caso de pinturas externas e chapas ondulatórias de plástico. São Paulo, 1983. Dissertação (Mestrado) - Escola Politécnica, Universidade de São Paulo.

FRIEL, J. M. Acrylic polymers as coatings binders. KOLESKE, J.V. ed. In: Paint and coating testing manual: fourteenth edition of the Gardner-Sward handbook. ASTM Manual Series: MNL 17, p.3-12, 1995.

GNECCO, C. Ensaios para determinação da composição e caracterização de tintas. In: Tintas e Vernizes: Ciência e Tecnologia. São Paulo: ABRAFATI, 1993, p. 111898. 
HELENE, P. R. L. Manual para reparo, reforço e proteção de estruturas de concreto. 2.ed. São Paulo, PINI, 1992.

- Contribuição ao estudo da corrosão em armaduras de concreto armado. São Paulo, 1993. Tese (Livre Docência) - Escola Politécnica, Universidade de São Paulo.

HEWLETT, P. C. Methods of protecting concrete - coatings and linings. DHIR, R. K.; GREEN, J. W. ed. In: Protection of concrete. London, Chapman and Hall, 1990, p. 105 - 29.

HOY, K.L. Coalescence and film formation from latexes. Journal of Coatings Technology. v. 68, n. 853, p.33-9, 1996.

JONES, M. R.; DHIR, R.K.; GILL, J.P. Concrete surface treatment: effect of exposure temperature on chloride diffusion resistance. Cement and Concrete Research, v. 25, n. 1, p. 197-208, 1995.

JOHN, V. M. Ativação de escória com cal. São Paulo, 1995. Tese (Doutorado)- Escola Politécnica, Universidade de São Paulo.

KOCKOTT, D. Natural and artificial weathering of polymers. Polymer Degradation and Stability. v. 25, p. 181-208, 1989.

LEEK, D. S.; POOLE, A. B. The breakdown of the passive film on highy, C. ield mild steel by chloride ions. In: Corrosion of Reinforcement in Concrete. ed.: PAGE C. L.; TREADAWAY, K. W. J. ; BAMFORTH, P. B. Elsevier Applied Science. London, p.65-73, 1990.

LEEMING, M. Surface treatments for the protection of concrete. DHIR, R. K.; GREEN, J. W. ed. In: Protection of concrete. London, Chapman and Hall, p. 13548, 1990. 
MAILVAGANAM, N. P. Repair and protection of concrete structures. CRC Press, Inc. Boca Raton, p. 473, 1992.

MANO, E. B. Polímeros como materiais de engenharia. São Paulo, Editora Edgard Blücher Ltda, 1991.

MARTENS, R. C. Waterborne coatings. Emulsion and water-soluble paints. New York, Van Nostrand Reinhold Company, 1981.

MARTIN, J. W.; SAUNDERS, S. C.; FLOYD, F. L.; WINEBURG, J. P. Methodologies for predicting the service lives of coating systems. Federation of Societies for Coatings Technology Blue Bell, PA, june 1996. (Federation Series on Coating Technology).

MARTORANO, R. \& WALDIE, J. Elastomeric wallcoatings. A novel approach to long-term concrete protection. Paint \& Ink International. p. 2-8, 1992.

MENG, B. Calculation of moisture transport coefficients on basis of relevant pore structure parameters. Materials and Structure, v. 27. p.125-134,1994.

McGILL, L. P.; HUMPAGE, M. Prolonging the life of reinforced concrete structures by surface treatment. DHIR, R. K.; GREEN, J. W. ed. In: Protection of concrete. London, Chapman and Hall, p. 191-200, 1990.

MORTON, G. The biodeterioration of plastics and rubber. Environmental Engineering, june, 1990.

MOSS, N. S. Two-pack epoxy coatings as protection for concrete strutures. In: OCCA Thames Valley Section Symposium. Durable and Protective Coatings for Concrete, 1988, Heathrow, London. 
NEVILLE, A. Chloride attack of reinforced concrete: a overview. Materials and Structures, v. 67, n. 850, p. 37-43, 1995.

NOLAN, G. T.; KAVANAGH, P. E. Computer simulation of particle packing in acrylic latex paints. Journal of Coatings Technology. v.64, n. 811, p.51-60, 1992.

O'HARA, K. Two-pack acrylic urethane systems. In: OCCA Thames Valley Section Symposium. Durable and Protective Coatings for Concrete, 1988, Heathrow, London.

OLDRING, P.K.T; HAYWARD, G. A manual of resins for surface coatings. Sita Technology, 1987.

OSHIRO, T.; SWAMY, R. N.; TANIKAWA, S. In-situ evaluation of a flexible surface coating for concrete to prevent chloride penetration and steel corrosion. In: International Conference of Durability of Concrete. 3. Nice; London, SP 145-45, p. $851-63,1994$.

PERRICHET, A. Développment de microorganismes á la surface des bétons et enduits. Materials and Structures, v. 17, n.98, p. 173-77, 1984.

REPETTE, W. L. Modelo de previsão de vida útil de revestimentos de proteção da superfície do concreto em meios de elevada agressividade. São Paulo, 1997. 231 . Tese (Doutorado) - Escola Politécnica, Universidade de São Paulo.

PAPADAKIS, V. G.; VAYENAS, C. G.; FARDIS, M. N. Fundamental modeling and experimental investigation on concrete carbonation. ACI Materials Journal, v. 88, n. 4 , p. $363-373,1991$. 
PFEIFER, D. W.; SCALI, M. J. Concrete sealers for protection of bridge structures. National Cooperative Highway Research Program . Report 244, p.21-35, Dec. 1981.

RПLEM committee TC 34-APB, Ageing of plastics in buildings. Materials and Structures. v. 14, n.81, 1981.

RYNDERS, R.M; HEGEDUS, C.R.; GILICINSKI, A.G. Characterization of particle coalescence in waterborne coating using atomic force microscopy. Journal of Coatings Technology. v.67, n. 845, p.59-69, 1995.

SASSE, H. R.; HONSINGER, D., Development and optimization of impregnation materials. DHIR, R. K.; GREEN, J. W. ed. In: Protection of concrete. London, Chapman and Hall, 1990, p. $177-190$.

SATTLER, E. Concrete protection with methacrylate resins. In: OCCA Thames Valley Section Symposium Durable and Protective Coatings for Concrete, 1988, Heathrow, London.

SCHWAMBORN, B. Surface protection systems for reinforced concrete structures. NAGATAKI, S.; NIREKI, T.; TOMOSAWA, F. ed. In: Durability of Building Materials and Components 6; London, E \& FN Spon. 1993. p. 844-55.

SEREDA, P.J. The structure of porous building materials. National Research of Council of Canada. CBD 127. Ottawa, 1970.

SHEEHAN, J.G. Electron microscopy. KOLESKE, J.V. ed. In: Paint and coating testing manual: fourteenth edition of the Gardner-Sward handbook. ASTM Manual Series: MNL 17, p. 815-25, 1995. 
SWAMY, R. N.; TANIKAWA, S. Surface coatings to preserve concrete durability. DHIR, R. K.; GREEN, J. W. ed. In: Protection of concrete. London, Chapman and Hall, p. 149-65, 1990.

SWAMY, R. N.; TANIKAWA, S. Control of steel corrosion in chloride contaminated concrete through Aron Wall surface coating. MALHOTRA, V. M. ed. ACI Publ. SP-126-20, v.1. p.371-91, 1991.

SWAMY, R. N.; TANIKAWA, S. An external surface coating to protect concret and steel from aggressive environments. Materials and Structures, v. 26, n. 162, 1993.

SWAMY, R. N.; TANIKAWA, S. In-situ evaluation of a flexible surface coating for concrete to prevent chloride penetration and steel corrosion. MALHOTRA, V. M. ed. ACI Publ. SP-145-45, v.1. p.851-61, 1994.

TYSALL, L. A. Industrial paints: basic principles. London, Pregamon Press LTD, 1964.

UEMOTO, K. L. Tintas para edificações não industriais: tipos e substratos mais comuns, preparo de superficie, aplicação, patologias, normas técnicas. In: Seminário sobre especificação e qualidade em construção civil. São Paulo, 1992. São Paulo, Menasce Comunicações, 1992.

UEMOTO, K. L.; AGOPYAN, V.; QUARCIONI, V. Resistência à penetração de íons cloreto em concretos tratados com sistemas de proteção. In: $37^{\circ}$ REIBRACIBRACON, Goiânia, 1995. Anais, São Paulo, 1995. 
UEMOTO, K. L.; AGOPYAN, V; JOHN, V. M. Redução da carbonatação de estruturas de concreto armado através de películas protetoras. In: $37^{\circ}$ REIBRACIBRACON, Goiânia, 1995. Anais, São Paulo, 1995.

UOMOTO, T.; TAKADA, Y. Factors affecting concrete carbonation rate. NAGATAKI, S.; NIREKI, T.; TOMOSAWA, F. ed. In: Durability of Building Materials and Components 6; London, E \& FN Spon, p. 1133-41, 1993.

VINK, P. et al. UV stability of water-borne acrylic coatings. Polymer Degradation and Stability. v. 48, p.155-60, 1995.

WINNIK, M. A ; WANG, Y; HALEY, F. Latex film formation at the molecular level: the effect of coalescing aids on polymer diffusion. Journal of Coatings Technology. v.64, n. 811, p.51-60, 1992.

WUNDERLICH, M. A análise instrumental na indústria de tintas. In: Tintas e Vernizes: Ciência e Tecnologia. São Paulo: ABRAFATI, 1993, p. 1094-115.

YASUI, M; FUKUSHIMA, M. Performance of high build coating materials for concrete structures for preventing corrosion damage. DHIR, R. K.; GREEN, J. W. ed. In: Protection of concrete. London, Chapman and Hall, 1990, p. 167 - 175. 